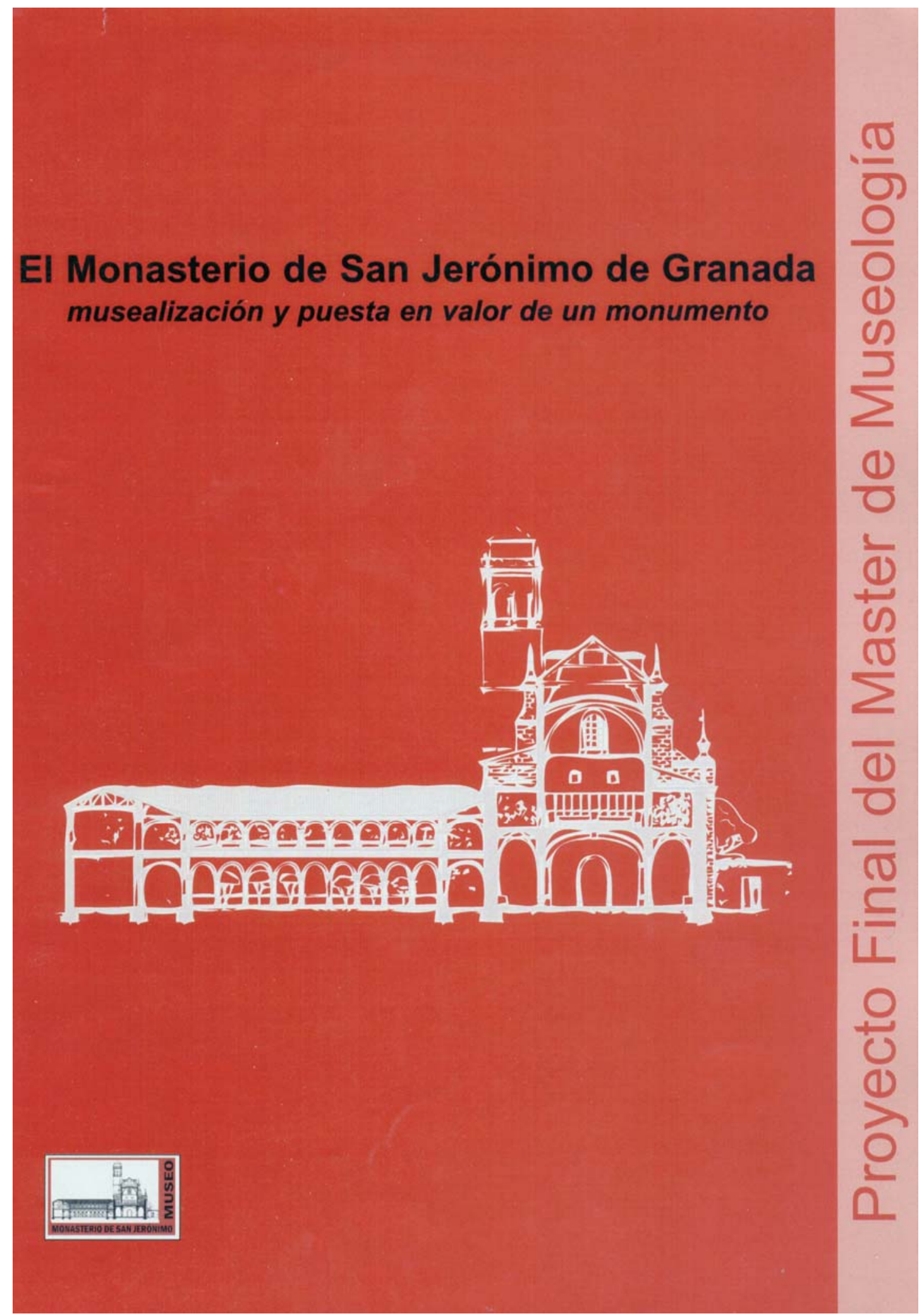


Editor: Editorial de la Universidad de Granada Autor: Ana María Gutiérrez García

D.L.: Gr. 615 - 2007

ISBN: 978-84-338-4274-9 


\section{El Monasterio de San Jerónimo de Granada musealización y puesta en valor de un monumento}

Proyecto final del Master de Museología.

Realizado por Ana María Gutiérrez García.

Coordinado por Fuensanta García de la Torre.

Master de Museología de la Universidad de Granada, I Edición (200-2001). 


\section{ÍNDICE}

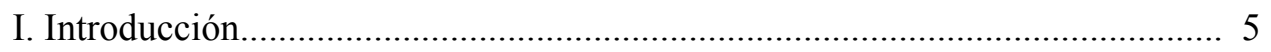

1. Valoración de la necesidad de musealizar el Monasterio de San Jerónimo 6

2. Antecedentes expositivos en el Monasterio de San Jerónimo.......................11

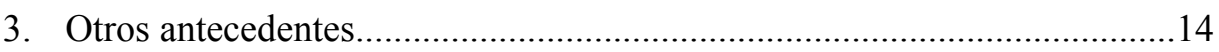

4. Funciones de la nueva institución..............................................................14

5. Nombre y contenido temático del nuevo museo..........................................15

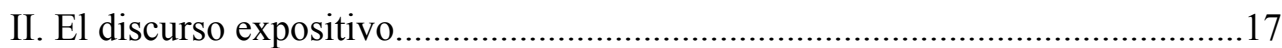

1. El discurso expositivo y las disciplinas científicas en que se apoya...........18

2. El tema principal y los subtemas............................................................18

3. Origen del monacato y de los monasterios.................................................20

4. Situación actual de los monasterios en España............................................22

5. La figura de San Jerónimo y la Historia de la Orden Jerónima....................25

6. Historia del Monasterio de San Jerónimo de Granada.................................29

7. Documentación disciplinar: Historia de la investigación y estado actual..46

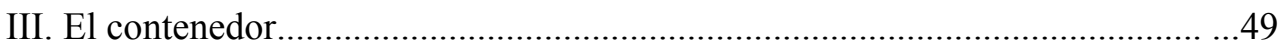

1. La condición tutelar del Monasterio y su espacio circundante.....................52

2. Evolución histórica del entorno del Monasterio............................................53

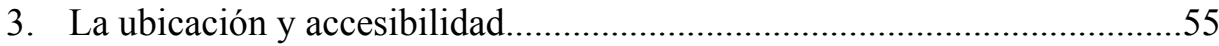

4. El recorrido propuesto.........................................................................60

5. Descripción de los espacios que se visitarán en el Monasterio....................63

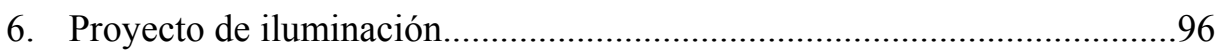

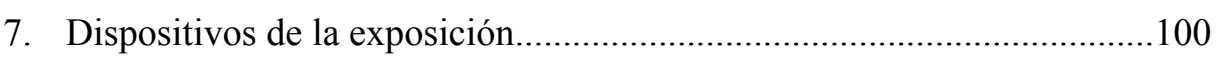

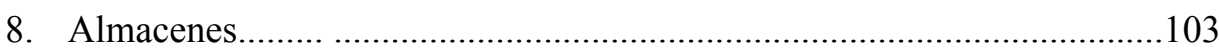

9. Áreas de servicio para el público general................................................107

10. Áreas de servicio para el público especial................................................108

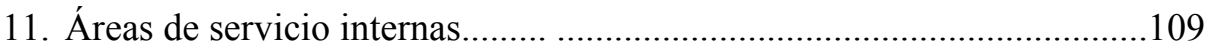

12. Especificaciones de señalética............................................................112

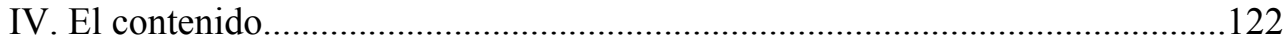

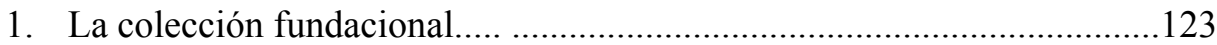

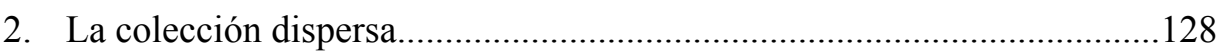

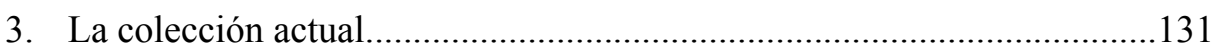


1. Determinación de las necesidades según el volumen y la naturaleza de la colección

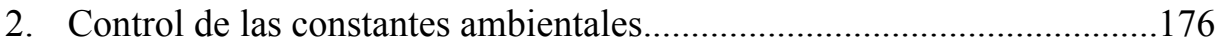

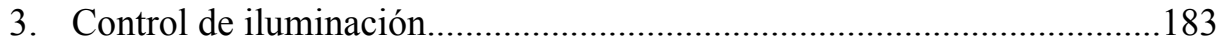

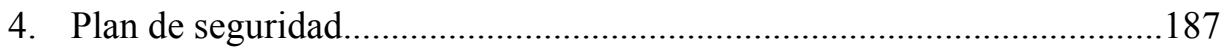

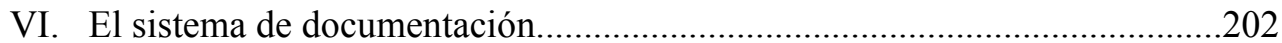

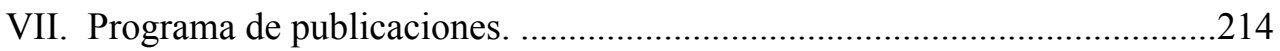

VIII. Estrategias de marketing y comunicación....................................................222

1. Servicios para el público general...........................................................226

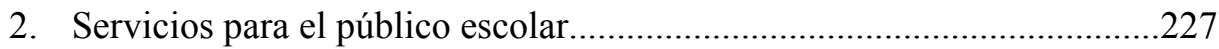

3. Servicios para públicos especiales........................................................228

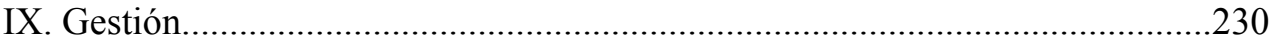

1. El patronato del Monasterio de San Jerónimo..........................................231

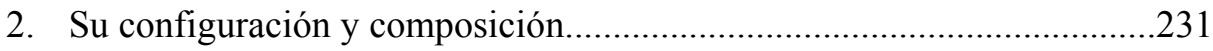

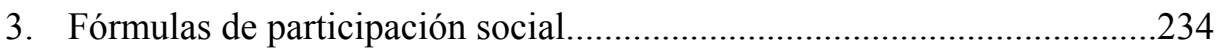

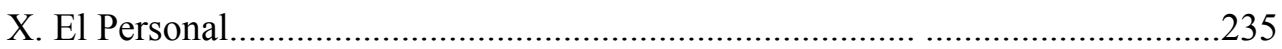

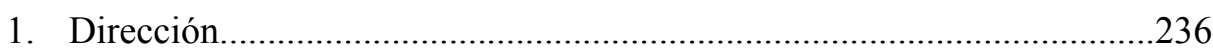

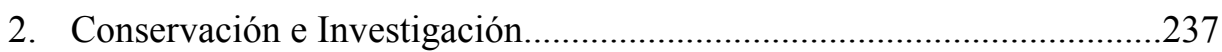

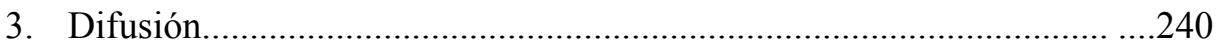

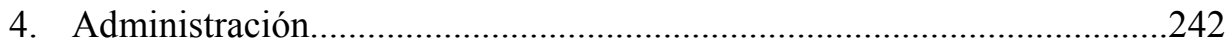

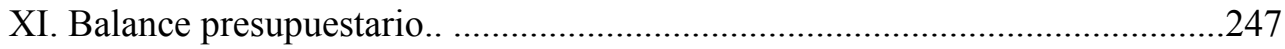

1. Aproximación al coste de apertura........................................................248

2. Aproximación al coste de mantenimiento.................................................248

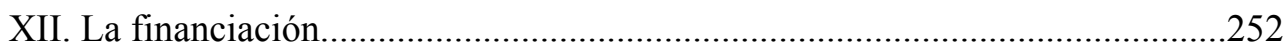

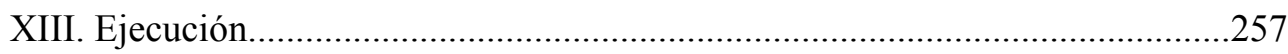

XIV. Previsiones de crecimiento, variabilidad y versatilidad.................................260

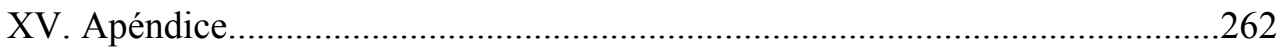

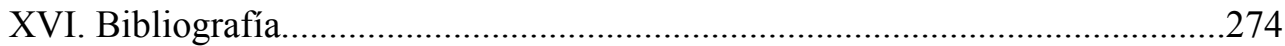

1. Bibliografía sobre el contenido y la temática científica............................275

2. Bibliografía sobre Museología y Museografía empleada en la redacción del proyecto. .288 
I. INTRODUCCIÓN 


\section{INTRODUCCIÓN.}

\section{Valoración de la necesidad de musealizar el Monasterio de San Jerónimo.}

Mi proyecto final del Master de Museología consiste en intentar devolver al Real Monasterio de San Jerónimo su esplendor pasado, así como permitir que la ciudad, y por tanto sus ciudadanos, al igual que otros visitantes de cualquier otra procedencia geográfica, puedan disfrutar de uno de los edificios más bellos y significativos en la historia de Granada, un conjunto arquitectónico que representa el centro de irradiación de la Granada del Renacimiento.

Adecuar las antiguas dependencias, hoy en desuso, y exponer en ellas las obras de arte de mayor interés que se conservan en él, atendiendo a los actuales criterios de conservación, seguridad, etcétera, pero sin olvidar que el Monasterio de San Jerónimo es un edificio histórico del siglo XVI, por lo que no fue diseñado para la inclusión de nuevas tecnologías. Esta adecuación la haremos con un principio: el máximo respeto a la arquitectura.

La idea surgió tras haber realizado, durante los meses de julio, agosto y septiembre del año 2000, como licenciada en Historia del Arte, prácticas de asesoramiento histórico y cultural en este Monasterio, gracias a una campaña para la difusión y compresión del monumento, coordinada por el Departamento de Historia del Arte de la Universidad de Granada y la Comunidad de Madres Jerónimas de Granada.

El patrimonio, tanto inmueble como de bienes muebles que la Orden Jerónima poseía en Granada era muy relevante pero debido a los avatares sufridos a lo largo de los años, entre los que podemos señalar, la ocupación francesa, la ley de la desamortización o los diferentes usos que ha tenido, han provocado que en buena parte esos bienes se encuentren en otros lugares o que desgraciadamente se haya perdido. Patrimonio muy importante, desde el punto de vista histórico y artístico ya que en la Orden Jerónima arte y religión eran dos conceptos muy relacionados entre sí, además como alguien ha escrito: "El origen del ser humano coincide con el origen del arte, y éstos a su vez son expresión del fenómeno religioso. Ciertamente arte y hombre son dos realidades intimamente unidas. Las creaciones artísticas son funciones esenciales del hombre, insustituibles para cada individuo y por las diversas colectividades... Además, originariamente el fin de la obre de arte no era la fruición estética ni servir de elemento decorativo; su finalidad fue ser expresión del fenómeno religioso y medio para vivirlo... La obra de arte, concebida en lo más profundo del ser humano, es manifestación exterior del mundo que late en la persona que la crea y en la cultura en la que nace". ${ }^{I}$

Este monasterio, desde el año 1973, hasta hoy, se encuentra habitado por una pequeña comunidad de monjas jerónimas, unas diecisiete, quienes procedían del antiguo convento de Santa Paula, situado entre la calle Santa Paula y la Gran

\footnotetext{
${ }^{1}$ Martínez Medina, F. [1989], p.92.
} 
Vía (en el que en estos momentos se están llevando a cabo las obras de construcción de un hotel de lujo de la compañía AC Hoteles).

Es esta comunidad la que posee la titularidad del Monasterio de San Jerónimo, gracias a la actuación realizada por Sor Cristina de la Cruz Arteaga, Madre superiora del Convento de Santa Paula de Sevilla e hija y heredera de Joaquín de Arteaga, Duque del Infantado, propietario del Carmen de los Mártires en el recinto de la Alhambra, Sor Cristina lo canjeó al Ayuntamiento por el monasterio de San Jerónimo, que se cedió en usufructo a la Orden Jerónima por los decretos de 20 de septiembre de 1962 y 4 de marzo de 1965, y la ley de 22 de junio de 1967. El 21 de julio de 1973 se les cedió el monasterio y el 26 de enero de 1974 se firmó la escritura de cesión.

En cuanto a la Orden Jerónima, el padre y fundamento de este linaje espiritual es San Jerónimo, quien tuvo dos grandes ideales durante su vida: las Sagradas Escrituras y la vida monástica. Nació hacía el año $347^{2}$ en Estridón, en la actual Yugoslavia, de niño recibió una esmerada formación ya que sus padres tenían una buena posición económica, por lo que lo enviaron a Roma en el año 360, allí cursó estudios de gramática, retórica y filosofía. Allí se dedicó por entero al estudio de los clásicos, lo que dejó en él una huella imborrable, que se dejará ver en su estilo literario. Vivió durante dos años, 375 y 376 en el desierto de Calcis, después volvió a Roma, donde permaneció en torno al papá Dámaso, hasta el 385 que se marcha a Belén con dos matronas romanas: Paula y Eustoquia, con quienes fundará allí, un convento y tres más femeninos, todos bajo su dirección espiritual.

Fue quien tradujo la Biblia al latín, la denominada Vulgata, que ha sido la oficial de la Iglesia Católica durante unos quince siglos. Murió en Belén el 30 de septiembre del año 420, sus restos se encuentran en la Basílica de Santa María la Mayor en Roma.

El espíritu y los escritos de San Jerónimo permanecieron en el tiempo hasta que ya en el siglo XIV surgen algunos grupos de ermitaños en distintos puntos de la Península Ibérica, entre los que destacan Pedro Fernández de Pecha y Fernando Yañez de Figueroa, quienes tras algunos años de vida eremítica decidieron vincularse a alguna regla, así el 18 de octubre de 1373 el papa Gregorio XI les otorga la Regla de San Agustín, permitiéndoles hacer constituciones propias y que se denominaran hermanos o ermitaños de San Jerónimo.

Se constituirán en 1415 como monacato regular, contaban ya por entonces con unos veinticinco monasterios. Pero en el siglo XIX los monjes debido a las leyes exclaustradoras abandonan los monasterios y la Orden está a punto de desaparecer. Las monjas jerónimas que no se habían visto afectadas por esta situación les ayudan y en el año 1925 la Santa Sede otorga un rescripto de restauración, en la actualidad existen sólo dos comunidades, una en Santa María del Parral (Segovia) y otra en San Jerónimo de Yuste (Cáceres).

\footnotetext{
${ }^{2}$ En otros estudios sobre la vida de San Jerónimo se da el año 342 como año de nacimiento.
} 
Podemos definir a la Orden Jerónima como una institución monástica, de tendencia puramente contemplativa, que en soledad y silencio, en asidua oración y animosa penitencia, pretende llevar a sus monjes a la unión con Dios.

En este clima, la vida del monje jerónimo se desarrolla dedicando la mañana al trabajo, medio normal para subvenir a sus necesidades, para ayudar al hermano necesitado y para mantener el equilibrio interior. La tarde la dispone para dedicarse con asiduidad a ejercicios de vida contemplativa e intelectual: oración lectura, estudio... Y en el curso del día, santificando todas las horas, la celebración cantada de la Liturgia de las Horas -las alabanzas divinas- y la Misa Conventual, primordial ocupación del jerónimo, que orienta toda su manera de vida, sus leyes y costumbres.

Junto a los Jerónimos, surgen las Jerónimas, quienes siguen las huellas, como en otro tiempo hicieron las santas Paula y Eustoquia.

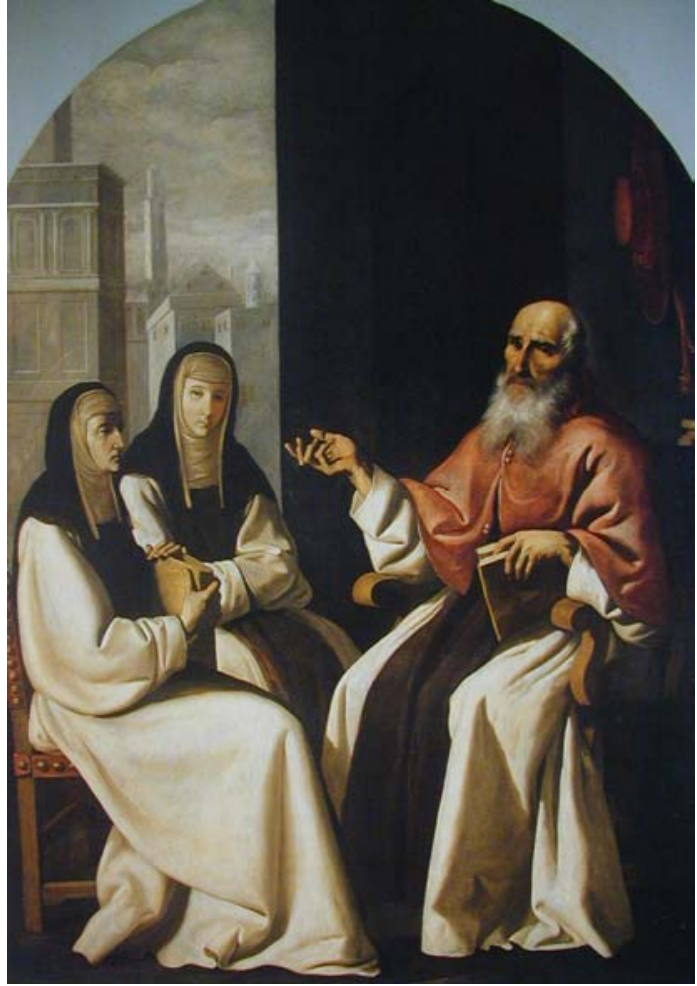

San Jerónimo con las Santas Paula y Eustoquia
Las jerónimas comenzaron en Toledo, cuando un grupo de mujeres, entre las que destacan doña María García y doña Mayor Gómez, empiezan ejercitándose en obras de humildad y caridad y, por fin, se retiran a una casa de su propiedad para consagrar su vida a Dios en oración y penitencia. Alma de esta floración es fray Pedro Fernández Pecha quien en 1374 fundaba el Monasterio de Santa María de La Sisla en las proximidades de la ciudad. Él las atiende, las orienta y les va perfilando su modo de vida en todo semejante a la recién fundada Orden de San Jerónimo.

Este primer brote dio origen al Monasterio de San Pablo de "beatas de San Jerónimo", como se las comenzó a llamar. Se mantienen con gran fama de observancia y santidad y propagan por distintos lugares de España. 
Pero volvamos de nuevo a Granada, donde los jerónimos llevan a proyecto del monasterio buena parte de la filosofía de la Orden, considerada la más refinada en cultura y amante de las artes. Fue en el siglo XVI, cuando se comenzaron las obras del actual monasterio, sabemos que la primera piedra de la iglesia fue colocada en 1519, las obras contaron con la intervención de maestros de la talla de Jacobo Florentino "el Indaco" o de Diego de Siloé y que la primera comunidad, compuesta por 25 monjes jerónimos, comenzó a habitarlo en al año 1521

Se construyó en los terrenos que los Reyes Católicos cedieron a los jerónimos. La Corona, tras la conquista de la ciudad de Granada ayudó a las órdenes más importantes a establecerse en ella, así a los franciscanos le cedieron terreno en la Alhambra y a los dominicos otro en el Realejo.

En el año 1523 el emperador Carlos V accedió a ceder a Dña. María de Manrique, duquesa de Sesa y Terranova y viuda de Gonzalo Fernández de Córdoba, "el Gran Capitán", la capilla mayor de la Iglesia para enterramiento de su marido, a cambio de que Dña. María adquiriera la obligación de pagar y llevar a cabo la terminación de la iglesia, el retablo, la reja y los túmulos. Los restos del Gran Capitán fueron llevados hasta San Jerónimo desde el convento de San Francisco Casa Grande en cortejo fúnebre, junto a otros familiares. En 1568 su nieto, para completar la decoración cedió a la Orden, con la aprobación del rey Felipe II, el Cortijo de Ansola que correspondía a su mayorazgo, obligando a los monjes a hacer con sus rentas el retablo, la reja, solería y los sepulcros, que nunca se realizarán. La iglesia no se terminará hasta en el año 1723 cuando Juan de Medina la decore por completo, a base de pinturas murales. El monasterio va a servir como lugar de enterramiento de grandes e importantes familias.

Los monjes jerónimos permanecieron en el monasterio desde 1521 hasta 1835, año en el que fueron expulsados de él, aunque quizás el peor momento que sufrió el monumento fue con la ocupación francesa, se demolió la torre, se quemó la madera, se fundieron las rejas, etcétera.

Tras la marcha de los monjes el monasterio se dedicó a cuartel de caballería, siendo de uso militar hasta su devolución a la Orden.

El día 3 de junio de 1931 fue declarado Monumento arquitectónico y artístico nacional. La restauración del edificio se llevó a cabo en los años 60 .

Todos esos avatares provocaron la situación actual del monasterio. Éste presenta un aspecto "desangelado" ya que las distintas dependencias del monasterio se encuentran vacías, sin obras y las que hay no están en la mejor situación, pues no existe un adecuado sistema de iluminación que permita su contemplación, además el conjunto tampoco se encuentra adaptado para personas con algún tipo de minusvalía física, ni tiene instalación alguna en cuanto a la seguridad del edificio y de las colecciones y de las personas. 
No existe ningún tipo de señalética ni de personal que informe a los visitantes de lo que están viendo, ni en el monasterio ni en la iglesia. Sólo existe una pequeña guía que puede comprarse por cien pesetas, en varios idiomas, aunque está anticuada y tiene varios errores.

Todo esto me llevó a elegir Monasterio para el Proyecto Fin de Master, a pesar de ser consciente de la gran dificultad que conlleva trabajar con un edificio de la importancia del Real Monasterio de San Jerónimo de Granada, catalogado como bien de interés cultural.

El monasterio podrá ser visitado casi en su totalidad, quedando exclusivamente restringido el paso a la zona de clausura, que se mantendrá para el uso de las monjas.

Existe también la posibilidad de utilizar otros espacios, así, la Escuela de Latín y Música, un antiguo edificio que se encuentra en absoluta ruina y sin ninguna función. Su ubicación lo hace perfecto, ya que ocupa todo un lateral del Compás del Monasterio, por lo que se mantendría la fachada exterior, y en el interior se construirían espacios nuevos. Este edificio podría albergar algunos de los espacios de reserva y servicios y también se puede contemplar (hay suficiente espacio) una sala de exposiciones temporales. de:

La propuesta, por tanto, se plantea para la musealización y puesta en valor

- La Iglesia.

- El Monasterio, con la excepción de la zona de clausura.

- La Escuela de Latín y Música.

\section{Antecedentes expositivos en el Monasterio de San Jerónimo.}

Tanto la iglesia como el Monasterio de San Jerónimo han servido en ocasiones como espacio arquitectónico para albergar exposiciones, que a continuación exponemos.

Con motivo de las fiestas del Corpus Christi se celebró, durante los meses de mayo y junio de 1940, en la iglesia de San Jerónimo la exposición: Escultura Religiosa Granadina desde la Reconquista hasta Alonso Cano. Fue organizada por el Excmo. Ayuntamiento de Granada y la Comisaría de Defensa del Patrimonio Artístico Nacional en Andalucía Oriental. Se presentaron un total de 254 esculturas, procedentes de la Santa Iglesia Catedral, de la Capilla Real, de numerosos conventos e iglesias de la ciudad y de la provincia, del Palacio Arzobispal de La Zubia, de la Puerta de la Justicia de la Alhambra, del Museo de Bellas Artes, del Museo Casa de los Tiros y de colecciones privadas.

Podemos afirmar, tras haber consultado el catálogo que se publicó, que las obras seleccionadas representaban lo mejor, desde el punto de vista artístico, de 
la escultura religiosa de Granada. Como ejemplo, señalaremos, sólo algunas obras: Virgen de la Antigua de la Catedral; Los Reyes Católicos orantes y el grupo de La Adoración de los Reyes del retablo de la Capilla Real, obra de Felipe Vigarny; el Santo Entierro de Jacobo Florentino de San Jerónimo; el Cristo de San Agustín; los tableros en relieve y varias esculturas de la iglesia parroquial de Los Ogíjares, de Diego Pesquera; de Diego Siloé el Cristo atado a la columna, de San Miguel; la Virgen con el Niño del Salvador o San Juan Evangelista del Museo de Bellas Artes; de Pablo de Rojas San Esteban y San Gregorio, ambos de la Catedral, la Virgen en el Calvario del convento del Ángel; de Baltasar de Arce San Cristóbal y los cuatro Evangelistas, de San Cristóbal; el Crucificado de Santo Domingo; el Calvario de Diego de Aranda, de Santa Ana; Santa Ana, la Virgen y el Niño de Diego de Pesquera, la de la Catedral y la de San Andrés; San Antón de la iglesia de Monachil; Cristo con la cruz a cuestas de Pablo de Rojas, de Nuestra Señora de las Angustias; Crucificados de Rojas, como el de La Zubia, el de la Catedral o el del Sagrario; Santa Lucía, también de Rojas, de Santo Domingo; el Ecce Homo de la Cartuja; la Sagrada Familia de Bernabé de Gaviria, de Santa Ana; Santiago a caballo de Alonso de Mena, de la Catedral; el Ecce Homo de Bernardo de Mora, de la Capilla Real; Cristo yacente y el Niño Jesús del Gran Capitán, ambos de Santa Paula.

Otra exposición fue la que se celebró con motivo de la celebración del Año Santo Mariano, en el año 1952, Imágenes de María en los Templos de Granada. Exposición de pinturas y esculturas relativas a Nuestra Señora desde los siglos XV al XIX, presentándose un total de 54 piezas. Entre ellas señalaremos algunas, así en la escultura: Inmaculadas como la de Pablo de Rojas, de San Juan de los Reyes; varias de Alonso de Mena, como la de San Matías; la Virgen con el Niño de Roberto Alemán, del Museo de la Alhambra; la Virgen del Niño de Alonso de Mena, de la Piedad y de San Cecilio; la de Alonso Cano del Museo de la Catedral; la Virgen de las Angustias de San Andrés; la Soledad de José de Mora, de Santa Ana; la Virgen de la Esperanza de Risueño, también de Santa Ana y en cuanto a pintura la Virgen de las Angustias de Francisco Chacón, de los Escolapios; la Inmaculada de Alonso Cano, de la Catedral; la Virgen con el Niño de Alonso Cano, de la Curia; la Virgen del Rosario de Pedro Atanasio Bocanegra; la Inmaculada de fray José Sánchez Cotán o la Asunción de Juan de Sevilla.

Y por último, como complemento a la representación musical de $\mathrm{La}$ Atlántida en la iglesia de San Jerónimo, en el año 1962, se celebró en el Refectorio del Monasterio una exposición de manuscritos del insigne músico Manuel de Falla, organizada por el Excmo. Ayuntamiento de Granada.

Podemos destacar de exposición el cartel anunciador, una reproducción del retrato de Falla realizada por Daniel Vázquez Díaz, además del diseño de las vitrinas, obra del arquitecto José María García de Paredes. 
Escultura RELigiosa Granadina DESDE LA RECONQUISTA HASTA ALONSO CANO EXPOSICION CELEBRADA EN GRANADA EN LAS PIESTAS

CATALOGO DE LA EXPOSICIÓN
AÑO SANTO MARIANO

\section{IMAGENES DE MARIA}

en los Templos de Granada

Exposición be pinturas y execlturas rejativas a

DAESTR I $5 E A O B M$

Sende for siglos XV at XIX

1

Tglesta be San 7erobaimo
Catálogo de la Exposición celebrada en la iglesia de San Jerónimo, 1940. Archivo Museo Casa de los Tiros.
Catálogo de la Exposición celebrada en la iglesia de San Jerónimo, 1952. Archivo Museo Casa de los Tiros.

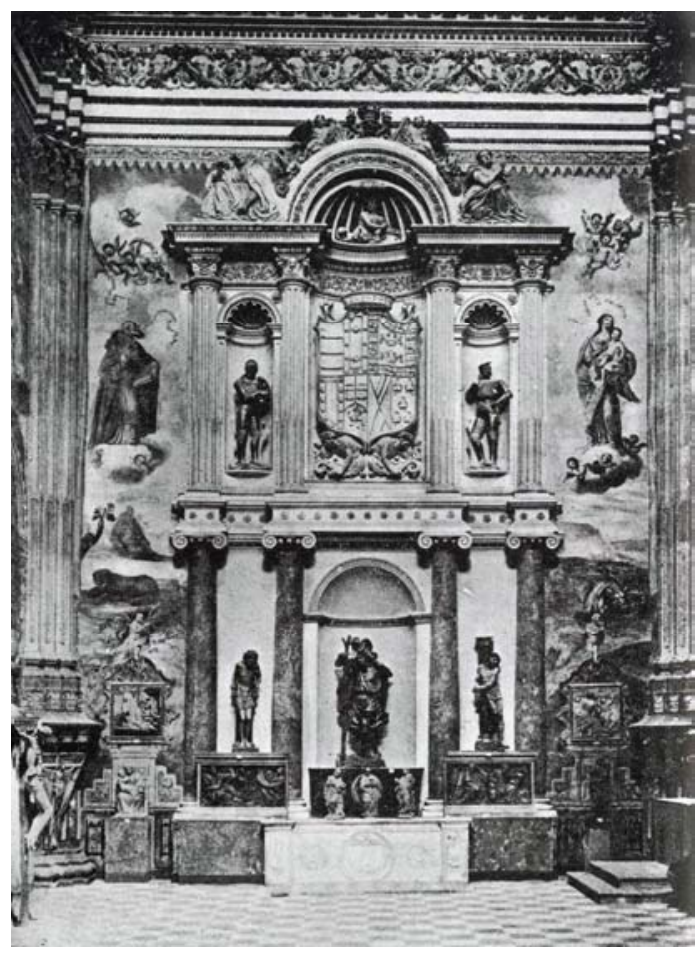

Imagen de la exposición del año 1940, en la que pueden apreciarse algunas de las obras expuestas. ${ }^{3}$

\footnotetext{
${ }^{3}$ Gómez Moreno, M. [1988], fig. XC.
} 


\section{SEA Otro triunfo grandioso de "ATLANTIDA" E $=$ IDEAL en el monasterio de San Jerónimo}

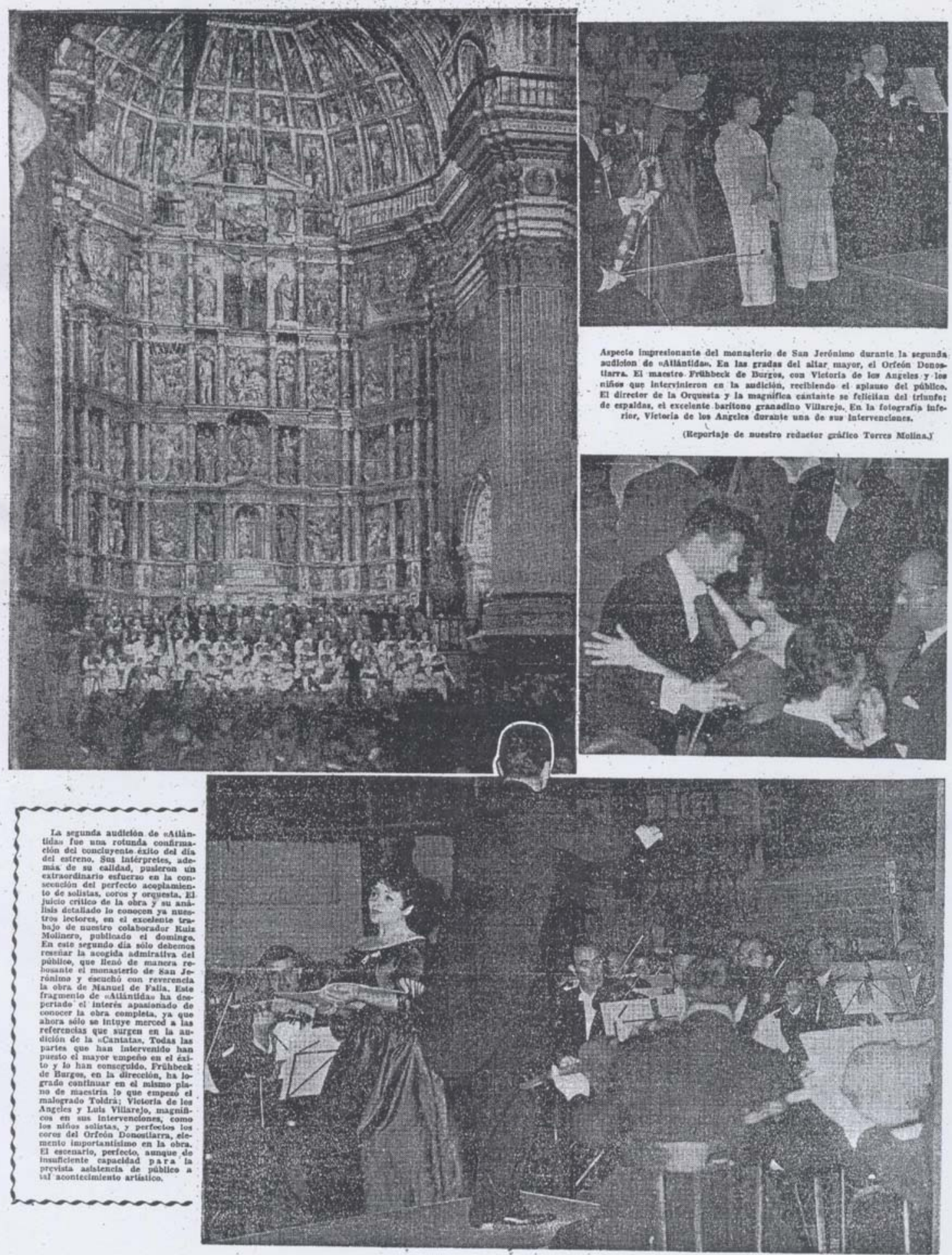

IDEAL, 3 de Junio de 1962. 


\section{Otros antecedentes.}

La iglesia del Monasterio de San Jerónimo posee muy buena acústica, por lo que ha servido como escenario para la celebración de numerosos conciertos, en especial con motivo de los Festivales Internacionales de Música y Danza que tienen lugar todos los años en la ciudad de Granada. No hay que olvidar la relación tan estrecha que la Orden Jerónima tenia con la música, ya que uno de sus fines principales era el esplendor del culto, acogiendo ésta con fruición. Además éste Monasterio albergó, como ya dijimos, la Escuela de música que contaba con un importante archivo musical y de la que salieron numerosos cantantes, compositores e instrumentistas.

Destacar la representación de la obra de Manuel de Falla, La Atlántida, en el XI Festival Internacional de Música y Danza, durante los días 30 de junio y 1 de julio de 1962. Fue un acontecimiento con carácter de estreno, similar al que tuvo lugar en Milán y Barcelona.

También se han desarrollado otras actividades en la iglesia de San Jerónimo así, tenia lugar en ella la lectura del Pregón Oficial de la Semana Santa de Granada, hasta que volvió a abrirse el Teatro Isabel la Católica.

\section{Las funciones de la nueva institución.}

De acuerdo con lo dispuesto en el artículo 59.3 de la Ley 16/1985, de 25 de junio, del Patrimonio Histórico Español, son Museos las instituciones de carácter permanente que adquieren, conservan, investigan, comunican y exhiben, para fines de estudio, educación y contemplación, conjuntos y colecciones de valor histórico, artístico, científico y técnico o de cualquier otra naturaleza cultural.

Siguiendo esta definición y el artículo 2 del Reglamento de los Museos de titularidad estatal y del Sistema Español de Museos, las funciones que desarrollará nuestra institución serán:

- La conservación del edificio y de las colecciones que alberga.

- La catalogación de las colecciones.

- La restauración del edificio y de sus colecciones.

- La exhibición ordenada de sus colecciones.

- La investigación, en el ámbito del edificio, de las colecciones que éste alberga y de todos los temas relacionados con ellos.

- La difusión del Monasterio de San Jerónimo y de sus colecciones. 
- La organización periódica de exposiciones científicas y divulgaciones acordes con la naturaleza de nuestra institución.

- La elaboración y publicación de catálogos y monografías de sus fondos.

- El desarrollo de una actividad didáctica respecto a sus contenidos.

\section{Nombre y contenido temático del nuevo museo.}

En cuanto al nombre que recibirá nuestra institución, es obvio que el Monasterio seguirá llamándose del mismo modo, aunque hemos pensado en añadirle el término de museo, es decir, se denominará: Monasterio y Museo de San Jerónimo de Granada.

El anagrama que hemos diseñado es el siguiente:

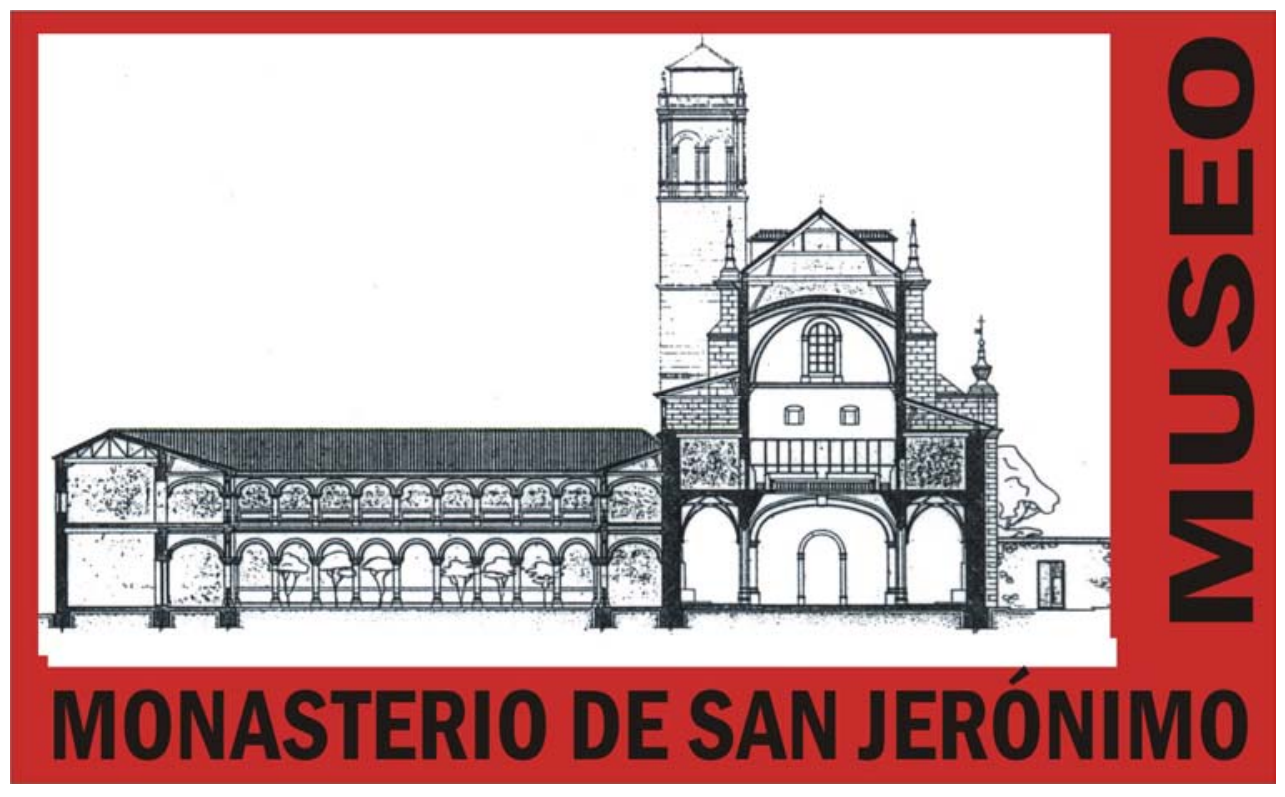

Pretendíamos que éste fuera un elemento significativo e identificativo del Monasterio, por lo que hemos seleccionado como motivo principal el alzado que realizo el arquitecto Prieto Moreno, en el año 1979, además hemos incorporado el color rojo porque es este el que representa a la figura de San Jerónimo, ya que desde el punto de vista iconológico es el color de los cardenales. 
Como ya hemos avanzado, el contenido temático del Monasterio Museo de San Jerónimo, será el propio monasterio, explicando su historia, su arquitectura, el significado y el por qué de cada una de las estancias. También, una selección de obras pictóricas, escultóricas y de orfebrería, con una cronología entre los siglos XVI y XIX. Pero queremos insistir en el hecho de que no utilizamos el Monasterio como un espacio para exponer una colección, sino que lo que nosotros presentamos es el propio edificio, su espacio, sólo que las obras que éste alberga nos ayudan a contextualizar este espacio monástico. 


\section{EL DISCURSO EXPOSITIVO.}




\section{EL DISCURSO EXPOSITIVO.}

\section{Discurso de la exposición y disciplinas científicas en que se apoya.}

Todo proceso de comunicación, necesita la existencia de tres elementos: el emisor, el medio y el receptor. La exposición es el medio por el que el emisor, que somos nosotros hace llegar al receptor, que es el visitante, un mensaje, es decir una reflexión discursiva sobre un determinado conocimiento o saber científico.

Nosotros, (siguiendo las conclusiones de Ángel García Blanco ${ }^{4}$ ) vamos a intentar a través del tratamiento comunicativo del hecho científico convertir el discurso científico en un mensaje mediante la exposición, adecuándolo al visitante, es decir, el destinatario de ese discurso, un receptor no experto.

"Como elemento mediador la exposición, en cuanto tal, debe ser autosuficiente para ser entendida y disfrutada sin necesidad de ningún otro elemento mediador ajeno a la propia exposición, produciéndose el efecto comunicativo mediante la interacción del visitante con ella.

Por otro lado, la mediación corresponde al conjunto de la exposición entendida toda ella como un sistema comunicativo complejo en el que intervienen varios medios o soportes informativos" $"$

Así por ejemplo, vamos a utilizar piezas, textos explicativos o música de fondos entre otros. Pero todo lo vamos a integrar en un único discurso, el de la exposición, es decir, la historia del Monasterio de San Jerónimo de Granada, ordenándolos de tal manera que se favorezca el acceso al significado de los objetos $o$ a la idea que queremos transmitir con ellos.

Para conseguirlo, nos apoyaremos en distintas disciplinas científicas, así: Historia, Historia del Arte, Historiografía, Hagiografía, Arquitectura, Arqueología, Antropología, Geografía Urbana, Cartografía Histórica, Museografía y Museología.

\section{El tema principal y los subtemas.}

Como ya hemos adelantado en la introducción, uno de los objetivos que este proyecto persigue es la puesta en valor del Monasterio de San Jerónimo, así como de las colecciones que éste alberga. Por lo que el tema principal que queremos hacer llegar al visitante es el propio Monasterio, pero no sólo desde el punto de vista artístico, sino explicando el por qué de lo que se va a ver, es decir, su origen, su significado, su importancia, etcétera. Así, por ejemplo, cuando el visitante se encuentre en el Claustro, además de conocer en que año fue construido, quién fue el arquitecto o cómo se denominan los arcos... podrá aprender cómo y

\footnotetext{
${ }^{4}$ García Blanco, A. [1999], pp. 67.

${ }^{5}$ García Blanco, A. [1999], pp. 67.
} 
por qué surgieron los claustros, qué función desempeñaban en los monasterios y en especial en la Orden Jerónima.

De este modo, a partir del discurso básico que sería la historia del Monasterio de San Jerónimo, irán surgiendo otros temas o subtemas. Entre ellos podemos señalar: la historia del monacato o cómo surgen los monasterios; la situación de los monasterios en la actualidad en España; la figura de San Jerónimo, la historia de la Orden Jerónima y de sus monasterios, su arquitectura, sus funciones, su relación con la Corona española; y ya en particular, el Monasterio de San Jerónimo de Granada, su fundación e historia, el significado del edificio en la ciudad, quienes lo han habilitado y la iglesia. Sin dejar de lado todos los bienes muebles que en él se conservan, gracias a los cuales podemos llegar a comprender mejor el arte realizado en Granada durante la etapa renacentista y barroca.

Para una mejor comprensión a continuación señalamos en un esquema los temas que queremos hacer llegar al visitante:

\section{Real Monasterio de San Jerónimo.}

- Historia del edificio:

- Arquitectura y significado:

- Dependencias Monasterio.

- Iglesia.

- Evolución del edificio:

- El edificio en la ciudad.

- Sus diferentes usos.

- Historia de la fundación:

- Fundación Real:

- Reyes Católicos.

- Carlos V e Isabel.

- Patrocinio Aristocrático:

- Gonzalo Fernández de Córdoba.

- Duquesa de Sesa.

- Otras familias.

- Historia de la Orden Jerónima: 
- Relación con la Corona.

- San Jerónimo.

- Iconografía de la Orden.

- Historia de la Comunidad que ha habilitado el Monasterio:

- Monjes jerónimos.

- Fray Hernando de Talavera, fray Ramiro de Alba, etc.

- Monjas jerónimas de Santa Paula.

- Historia y significado artístico de sus colecciones:

- Mobiliario.

- Pintura.

- Escultura.

- Orfebrería.

Algunos contenidos del esquema de éste discurso expositivo los vamos a exponer a continuación, el resto, los iremos desarrollando a lo largo de los diferentes apartados de éste Proyecto.

\section{Origen del monacato y de los monasterios.}

La cuestión de los orígenes del monacato cristiano ha sido estudiada por muchos autores, pero aún no se ha dado una respuesta satisfactoria, ya que haría falta un estudio con un enfoque multidisciplinar pues mientras los estudios de gran rigor metodológico ignoran la dimensión propiamente espiritual del monacato, muchos escritos sobre espiritualidad monástica carecen del rigor científico necesario. Nosotros vamos a realizar sólo una breve síntesis de la historia del monacato $^{6}$.

Este modo de vida nació en Oriente, Siria y Egipto, con el propósito de fomentar entre los cristianos la vida eremita que se basaba en los ideales del ascetismo. Cerca del año 300 San Antonio Abad se retiró como anacoreta, es decir, para practicar la vida solidaria del ermitaño, al desierto. Le seguirán otros, así Pacomio quien fue el primero en fundar una colectividad monástica, cerca de Tebas, para perseguir conjuntamente la vida ascética y alcanzar la perfección espiritual.

A lo largo del siglo IV el movimiento monacal se extendió, desde Egipto, por todo Oriente. Durante el siglo V, en el concilio de Calcedonia, los obispos adquirieron autoridad sobre los monasterios de sus diócesis y los votos monásticos pasaron a tener vigencia perpetua. El Occidente, los dos puntos clases en el

${ }^{6}$ Los datos que incluimos están extraídos de la siguiente dirección: www.Users.skynet.be/bs775533/Armand/Orignes-esp.htm. 
desarrollo del monaquismo estuvieron en Irlanda-Inglaterra e Italia. Monjes irlandeses actuaron en Inglaterra y desde allí en el resto de Europa del norte: San Columbano y sus discípulos evangelizaron parte de las Galias donde fundaron numerosos monasterios durante los siglos VI y VII (Luxeuil, Saint Gall, etc.); en las tierras germanas fueron los monjes anglosajones, entre ellos San Bonifacio, los que durante el siglo VIII evangelizaron a los invasores bárbaros.

La orden que alcanzó un mayor desarrollo en Occidente fue la benedictina fundada por San Benito de Nursia, hacia el año 529 en el monasterio de Monte Casino (Campania). La regla que San Benito dio a sus monjes vino a convertirse en el marco referencial de la vida monástica occidental. A las tradiciones del monaquismo antiguo unió nuevas normas disciplinares, tales como: la obligación de residir en comunidad en el monasterio frente a la vida errabunda de los ascetas primitivos; la regla de la comunidad exigía el cumplimiento de tres votos (pobreza, castidad y obediencia, entendida ésta como sumisión al abad); quizá lo más característico de la orden benedictina fue la importancia concedida al trabajo manual, equiparable a la oración como instrumento para alcanzar la santificación personal. San Benito dividió el tiempo para los siete oficios divinos y la obligación de desarrollar un trabajo, físico o intelectual, durante varias horas al día, adoptando la máxima de "ora et labora".

Los monasterios debían ser autónomos en la cobertura de sus necesidades, convirtiéndose así en factorías de los artículos de consumo derivados del ejercicio de la agricultura, la ganadería y viticultura. Construidos en el campo, entre los latifundios y las tierras de cultivo de los germanos, los monasterios se convirtieron en centros de evangelización, en granjas altamente productivas y en los únicos centros culturales de la época. Cuando llegaron los tiempos de crisis, durante el siglo $\mathrm{X}$, los monasterios fueron el refugio de salvación de la vida feudal. Además los monasterios tenían el cometido de atender las necesidades espirituales y culturales de los monjes benedictinos, los monasterios se convirtieron en centros de cultura donde se estudiaba y conservaba la historia y la literatura antiguas, se redactaban crónicas y se copiaban textos. Las bibliotecas de los monasterios recogieron los pocos manuscritos que quedaban de la cultura romana, los cuales fueron copiados detallada y minuciosamente por los monjes en los "scriptoria".

La regla de San Benito de Nursia se difundió por toda Europa, sobre todo después de que, gracias a la protección de San Gregorio Magno y de Carlomagno, se declarará obligatoria dicha regla benedictina en todos los conventos del reino franco. La influencia de la Iglesia, en las cortes de los monarcas germanos y en las capas populares, dio una gran unidad religiosa a la sociedad europea occidental cada vez más ruralizada y dominada por los grandes señores feudales. En este contexto la Iglesia emergió como poder que unifica, catequiza y enseña, produciendo además, dentro de una mentalidad cristiana, las primeras formas culturales y artísticas, en cierto modo independientes de la herencia romana.

Durante los siglos X y XI se produjo un impulso reformista de la vida monacal que pretendió contrarrestar la corriente secularizadora de la vida monástica que el feudalismo eclesiástico estaba potenciando entre el clero regular. 
Frente a esta tendencia, y ante la permanente ingerencia de los señores feudales laicos que pretendían ejercer un control jurisdiccional sobre los conventos situados en sus territorios, surgió el movimiento cluniacense que partió de la abadía de Cluny, fundada en el año 910, por el duque de Aquitania -Guillermo el Piadoso, desde donde se propugnó, además de una reforma en los aspectos económicos y administrativos de los monasterios benedictinos, una dependencia exclusiva de la jerarquía eclesiástica, fundamentalmente del papa, abandonando feudal de los señores jurisdiccionales, bien sean obispos y señores laicos, intensificando la implantación de una disciplina estricta y el reconocimiento del abad como la única autoridad monástica. Durante estos siglos el monasterio de Cluny se convirtió en el centro de la orden benedictina que extendió su reforma a más de 200 monasterios dispersados por toda Europa, desde España hasta Escocia y Polonia. Otras reformas que aspiraron a una perfección en la espiritualidad monacal fueron las propuestas por los camaldulenses, orden fundada en el año 1012 por Romualdo de Rávena y por los cartujos fundados por Bruno de Colonia en el año 1084.

En el año 1098 el abad Roberto de Molesme fundó en Citeux (Francia) la orden del Cister donde profesará a comienzos del siglo siguiente San Bernardo, fundador de la Abadía de Claraval, al noroeste de Francia, desde donde partirá otro gran movimiento reformista del monaquismo, la reforma cisterciense, que pretendió vivir con exigencia absoluta los ideales de San Benito: riguroso ascetismo, piedad y misticismo, sencillez y pobreza en los modos de vida conventual (esta faceta tuvo grandes repercusiones en los aspectos artísticos de la arquitectura medieval). Pronto cayó, a causa de las riquezas, en el relajamiento de la exigencia inicial, dando lugar al nacimiento de nuevas órdenes como por ejemplo la de los trapenses.

\section{Situación actual de los monasterios en España.}

El panorama actual en España en cuanto a monasterios, tanto masculinos como femeninos es el siguiente:

\section{- Monasterios de monjes.}

En España existen 44 monasterios de monjes pertenecientes a 13 institutos monacales, éstos cuentan con más de un millar de monjes y cerca de un centenar de novicios.

Los 6 Institutos de derecho pontificio tradicionalmente conocidos en España son:

- Benedictinos:

- Abadía de Ntra. Sra. de Montserrat (Barcelona), Samos (Lugo), Monforte de Lemos (Lugo), El Paular (Madrid), Ntra. Sra. de Estíbaliz (Alava), Lazcano (Guipúzcua), Valvanera (La Rioja) y El Miracle (Lérida); estos monasterios pertenecen a la Congregación Sublacense. 
- Abadía de Santo Domingo de Silos (Burgos), Ntra. Sra. de Montserrat (Madrid), Abadía de Sta. Cruz del Valle de los Caídos (Madrid) y Abadía de San Salvador de Leire en Yesa (Navarra), que pertenecen a la Congregación Solesmense.

- Sopetrán (Guadalajara), que pertenece a la Congragación alemana de Santa Otilia.

- Camaldulenses: Yermo camaldulense Ntra. Sra. de Herrera en San Felices (La Rioja).

- Cartujos: Cartuja de Ntra. Sra. de la Defensión en Jerez de la Frontera (Cádiz), Santa María de Miraflores (Burgos), Aula Dei en Peñaflor (Zaragoza), Ntra. Sra. de Porta Coeli (Valencia) y Montalegre en Tiana (Barcelona).

- Cistercienses: Abadía de Santa María de Poblet (Tarragona), Priorato de Santa María de Solius en Santa Cristina D'aro (Gerona) y Monasterio de Santa María de Valdediós (Asturias).

- Cistercienses de la Estricta Observancia: Abadías de Santa María de la Oliva en Carcastillo (Navarra), de San Pedro de Cárdena en Castrillo del Val (Burgos), de Santa María de Huerta (Soria); Monasterios de Santa María de Las Escalonías en Hornachuelos (Córdoba), de Santa María en Sobrado de los Monjes (La Coruña) y Santa María de la Asunción en Zenarrua (Vizcaya).

- Jerónimos: Monasterios de San Jerónimo en Cuacos de Yuste (Cáceres) y de Santa María del Parral en Segovia.

Los Institutos masculinos de derecho diocesano son:

- Benedictinos de la Santísima Trinidad en Santa Brígida (Las Palmas)

- Benedictinos de la Esperanza en Seró (Lérida)

- Ermitaños de San Pablo y San Antonio en Arta y Valldemosa (Mallorca)

- Fraternidad Monástica de la Paz en Castellón y Tangel (Alicante)

- Resurreccionistas en Las Palmas, Lucena y Santaella (Córdoba)

\section{- Monasterios de monjas.}

En cuanto a los monasterios de monjas, hay en España 912 monasterios femeninos con cerca de 13.000 monjas profesas y 400 novicias. La mayor parte son 
monasterios de clausura papal, se ordenan íntegramente a la contemplación, y sus miembros se ocupan sólo de Dios, en soledad y silencio, en constante oración y penitencia.

También existen algunos institutos contemplativos que practican una clausura llamada constitucional, por la que pueden alternar su contemplación con alguna actividad apostólica.

Los 44 Institutos monásticos distribuidos por toda España están asociados, en su mayoría, en 58 federaciones, asociaciones o congregaciones monásticas, así:

- Con más de una federación o asociación se encuentran 10 Institutos, que son:

- Agustinas: 2 federaciones.

- Benedictinas: 4 federaciones.

- Carmelitas Descalzas: 6 federaciones.

- Carmelitas de la Antigua Observancia: 3 federaciones.

- Clarisas Franciscanas: 8 federaciones.

- Clarisas Capuchinas: 2 federaciones.

- Concepcionistas Franciscanas: 7 federaciones.

- Dominicas: 3 federaciones.

- Franciscanas de la Tercera Orden: 2 federaciones.

- Visitación (Salesas): 2 federaciones.

- Con una sola federación o asociación:

- Agustinas Descalzas.

- Agustinas Recoletas.

- Brígidas.

- Canónigas de San Agustín.

- Cistercienses.

- Clarisas de la Divina Providencia.

- Comendadoras del Espíritu Santo.

- Comendadoras de San Juan de Jerusalén.

- Comendadoras de Santiago.

- Jerónimas.

- Justinianas.

- Mercedarias.

- Mínimas.

- Redentoristas.

- Siervas de María.

- Trinitarias.

- Con régimen centralizado hay 4 Institutos:

- Congregación Cisterciense de San Bernardo.

- Esclavas del Santísimo Sacramento y de la Inmaculada. 
- Oblatas de Cristo Sacerdote.

- Fraternidad Monástica de la Paz.

- Con federaciones o congregaciones que radican en el extranjero se encuentran 4 Institutos:

- Adoratrices Perpetuas del Santísimo Sacramento.

- Canonesas del Santo Sepulcro.

- Hermanas de Belén y de la Asunción.

- Hijas de la Cruz del Sagrado Corazón de Jesús.

- Carecen de vínculo asociativo 10 Institutos:

- Anunciada Celeste.

- Cartujas.

- Cistercienses (Trapenses)

- Concepcionistas.

- Hijas de María Nuestra Señora.

- Mercedarias Descalzas.

- Pasionistas.

- Premostratenses.

- Ursulinas.

- Institución Charitas.

\section{La figura de San Jerónimo y la Historia de la Orden Jerónima.}

- La figura de San Jerónimo.

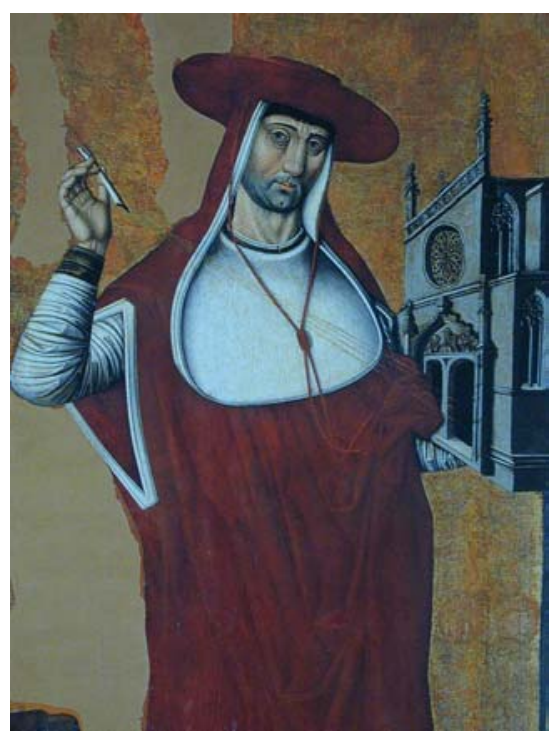

San Jerónimo.

Uno de los cuatro Doctores originales de la Iglesia Latina. Padre de las ciencias biblicas y traductor de la Biblia al latín. Presbitero, hombre de vida ascética, eminente literato. 
Jerónimo (Eusebius Hieronymus Sophronius), nació hacía el año $347^{7}$ en Estridón (en la actual Yugoslavia), una población pequeña situada en los confines de la región dámata de Panonia y el territorio de Italia, cerca de la ciudad de Aquilea. De niño recibió una esmerada formación ya que sus padres tenían una buena posición económica, por lo que lo enviaron a Roma en el año 360, donde cursó estudios de gramática, retórica y filosofía. Allí se dedicó por entero al estudio de los clásicos.

En el año 370, Jerónimo se estableció temporalmente en Aquilea, hasta que en el 374 se marcha a Antioquia, donde sufrió una grave enfermedad, en una de sus cartas a Santa Eustoquia cuenta el propio Jerónimo que debido al delirio de la fiebre, tuvo un sueño en el que se vio ante el trono de Jesucristo para ser juzgado, quien le decía que mentía, esta experiencia produjo un profundo efecto en su espíritu.

Como consecuencia, se retiró a Calcis, un desierto al sureste de Antioquia, allí pasó cuatro años totalmente sólo en diálogo con su alma, sufriendo multitud de tentaciones.

Después volvió a Roma, donde recibió la ordenación sacerdotal de manos del pontífice San Dámaso, aunque él no deseaba recibirla ya que prefería la vida monástica de reclusión, sólo acepto bajo la condición de que no estaba obligado a servir a tal o cual iglesia en el ejercicio de su ministerio.

Poco después de recibir las órdenes se trasladó a Constantinopla a fin de estudiar las Sagradas Escrituras junto con San Gregorio Nazianceno, hasta que en el año 382 se marcha de nuevo a Roma donde era el secretario de San Dámaso hasta que este murió en el 385. Es entonces cuando se marcha a Belén junto con varias mujeres romanas que habían decidido compartir su exilio y vivir como religiosas en Tierra Santa, así Santa Paula y Santa Eustaquia, gracias a la generosidad de la primera se construyó un monasterio para hombres, próximo a la Basílica de la Natividad, en Belén, lo mismo que otros tres edificios para comunidades de mujeres. San Jerónimo vivía en una caverna cerca de donde había nacido Jesucristo.

Conocía muchas lenguas, así el griego, arameo o hebreo, por lo que se le encargó la traducción de los libros del Antiguo Testamento escritos en hebreo, revisó la antigua versión latina de los Evangelios y los Salmos. El Concilio de Trento designó la versión de San Jerónimo, conocida como la Vulgata, el texto bíblico latino auténtico o autorizado por la Iglesia Católica. En el año 1907, el papa Pío X confió a los monjes benedictinos la tarea de restaurar en lo posible los textos de San Jerónimo en la Vulgata, que al cabo de quince siglos de usos, habían sido considerablemente modificados y corregidos.

Murió el 30 de septiembre del año 420, fue sepultado en la iglesia de la Natividad, cerca de la tumba de Paula y Eustoquia que habían muerto antes, pero

\footnotetext{
${ }^{7}$ En otros estudios sobre la vida de San Jerónimo se da el año 342 como año de nacimiento.
} 
mucho tiempo después sus restos fueron trasladados a la basílica de Santa María la Mayor en Roma, donde reposan actualmente.

\section{- La Orden de San Jerónimo.}

El padre y fundamento de este linaje espiritual es San Jerónimo, quien tuvo dos grandes ideales: la Sagrada Escritura y la vida monástica. Su espíritu persiste en el tiempo por su fama de santidad y por sus escritos, medios por los de que durante el siglo XIV diversos grupos de hombres, en España y en Italia, con deseos de vida perfecta, inspirándose en la vida y enseñanzas del santo, intentarán vivir su carisma bajo distintos aspectos, dando origen a otros tantos institutos de vida consagrada.

Hay que situar los orígenes de la Orden de San Jerónimo en el siglo XIV español, en un momento de decadencia desde un punto de vista religioso y eclesial. Pero suenan gritos de reforma, y aquí es donde hay que situar los orígenes de la Orden de San Jerónimo, que es uno de los primeros frutos de esa reforma deseada. Diseminados por distintos puntos de la geografía ibérica surgen grupos de ermitaños que profesan especial devoción y tienen un gran deseo de imitar a aquel santo y docto varón.

Estos ermitaños, entre los que destacan Pedro Fernández Pecha y Fernando Yáñez de Figueroa, después de varios años de vida eremítica, consideran que sería más provechoso atarse con los vínculos de alguna regla aprobada y deciden abrazar la vida cenobítica. Gregorio XI les concede esta gracia el 18 de octubre de 1373, les otorga la Regla de san Agustín, les permite que puedan hacer constituciones propias y que se llamen hermanos o ermitaños de San Jerónimo.

Desde entonces comienza la evolución por constituir en monacato regular. Ya en 1415, fecha de la unión de la Orden, pueden contarse veinticinco monasterios. Siguen las fundaciones, principalmente en el siglo XVI, hasta llegar a 48 monasterios cuando llega la revolución liberal del siglo XIX, habitados entonces por unos mil monjes, que se ven obligados a abandonar para siempre sus monasterios. La suerte de estas casas fue muy diversa: los más acabaron en ruinas, otros fueron rescatados por la Iglesia o entregados a otras órdenes religiosas, otros quedaron convertidos en cualquier cosa: fábrica de

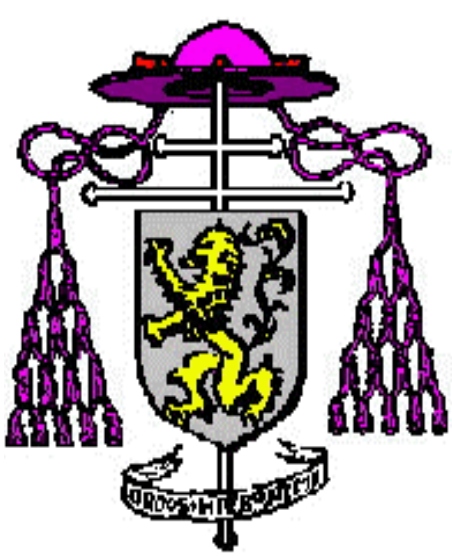
cerveza, cebadero de cerdos, fincas de recreo...

Escudo de la Orden de San Jerónimo Ordo Sancti Hieronymi (O.H.S) 
Pero cuando todavía no habían transcurrido los cien años que el derecho eclesiástico señala para la prescripción canónica, gracias a la ayuda de las monjas jerónimas, a las que no había afectado la exclaustración, en 1925 se obtiene de la Santa Sede un rescripto de restauración, y ésta comienza en el Monasterio de Santa María del Parral, en Segovia. Pero la república de 1931 y la guerra civil de 19361939 y dificultades de diverso género van a retrasar la restauración de la Orden, hasta que puede constituirse el gobierno general en 1969. En la actualidad existen dos comunidades, una en Santa María del Parral y otra en San Jerónimo de Yuste (Cáceres).

La Orden Jerónima se define así misma como "una institución monástica, de tendencia puramente contemplativa, que en soledad y silencio, en asidua oración y animosa penitencia, pretende llevar a sus monjes a la unión con Dios, consciente, por otro lado, de que cuanto más intensa sea esta unión por su propia donación en la vida monástica, tanto más espléndida se hace la vida de la Iglesia y más vigorosamente se fecunda su apostolado."

En este clima, la vida del monje jerónimo se desarrolla dedicando la mañana al trabajo, medio normal para subvenir a sus necesidades, para ayudar al hermano necesitado y para mantener el equilibrio interior. La tarde la dispone para dedicarse con asiduidad a ejercicios de vida contemplativa e intelectual: oración lectura, estudio... Y en el curso del día, santificando todas las horas, la celebración cantada de la Liturgia de las Horas -las alabanzas divinas- y la Misa Conventual, primordial ocupación del jerónimo, que orienta toda su manera de vida, sus leyes y costumbres.

Junto a los Jerónimos, surgen las Jerónimas, un grupo de mujeres que siguen las huellas de San Jerónimo, como en otro tiempo lo hicieron las santas Paula y Eustoquia.

Todo comenzó en Toledo cuando un grupo de mujeres de santa vida, entre las que destacan doña María García y doña Mayor Gómez, empiezan a ejercitarse en obras de humildad y caridad y, después, se retiran a una casa de su propiedad para consagrar su vida a Dios en oración y penitencia. La persona que les orientó en todo este proceso fue fray Pedro Fernández Pecha, quién en 1374 fundaba el Monasterio de Santa María de La Sisla en las proximidades de la ciudad. Él las atiende, las orienta y les va perfilando su modo de vida en todo semejante a la recién fundada Orden de San Jerónimo. Este primer brote dio origen al Monasterio de San Pablo de "beatas de San Jerónimo", como se las comenzó a llamar. Se mantienen con gran fama de observancia y santidad y propagan por distintos lugares de España.

En la actualidad existen 17 monasterios, la mayoría de los cuales, a pesar de sus muchos avatares a través del tiempo, perseveran desde su fundación. Otros son de fundación reciente. Los señalamos a continuación:

- San Pablo (Toledo, 1464), 
- Santa Marta (Córdoba, 1464),

- Santa Paula (Sevilla, 1475),

- San Matías (Barcelona, 1475),

- Santa Isabel (Palma de Mallorca, 1485),

- La Concepción de Santa María (Trujillo, s. XV),

- La Concepción Jerónima (Madrid, 1509),

- San Bartolomé (Inca, 1530),

- Santa Paula [hoy San Jerónimo] (Granada, 1553),

- Santa María (Morón, 1568),

- Nuestra Señora de la Salud (Garrovillas, 1572),

- Nuestra Señora de los Remedios (Brihuega - Yunquera de Henares, 1596),

- Corpus Christi (Madrid, 1605),

- Nuestra Señora de los Ángeles (Constantina, 1951),

- Nuestra Señora de las Mercedes (Almodóvar del Campo, 1964),

- Santa María de Jesús (Cáceres, 1975),

- Nuestra Señora de Belén (Toral de los Guzmanes, 1990).

\section{Historia del monasterio.}

El monasterio de San Jerónimo de Granada tuvo sus antecedentes en la ciudad de Santa Fe, en el convento de Santa Catalina mártir, donado a los monjes jerónimos el mismo año de la ocupación de Granada, 1492, por los Reyes Católicos. Este convento fue ofrecido a la Orden a la vez que el de Santa Engracia en Zaragoza, y ambos se aceptaron en el mismo capítulo de la Orden, celebrado el 15 de mayo de 1492 en el monasterio de Lupiana.

En aquel momento, se recuperaba la ciudad de las manos árabes, los Reyes cedieron varios edificios a distintas ordenes para que comenzaran su labor en la 
ciudad, así el convento de la Alhambra fue cedido a los Franciscanos y el de Santa Isabel a los Dominicos.

El que se donó a la Orden Jerónima consistía en una casa en la que habitaban los Reyes Católicos en Santa Fe, se llamaba de Santa Catalina, por ser el día 25 de noviembre aquel en que llegaron los árabes para hacer el primer contacto que condujo a la entrega de la ciudad de Granada.

Una vez conquistada Granada por los Reyes Católico, los monjes decidieron trasladarse a esta, pues la presencia del ejército había dejado el lugar desolado. Se establecieron, en un principio, en una casa con huerta llamada El Nublo, cuya propiedad había pasado de los reyes nazaritas a manos de los reyes cristianos, quienes la cedieron junto a otros bienes a la Orden Jerónima.

La edificación del monasterio comenzó unos años después, en 1496, en un nuevo terreno donado por los reyes Católicos, las fincas denominadas $L a$ Almoraba. Esta última donación consistía en casa, huerta, molino y algunas otras propiedades, también habían pertenecido a los reyes árabes. Este lugar es el que actualmente ocupa el Hospital de San Juan de Dios.

En el año 1500 los reyes cedieron a los monjes toda la piedra del cementerio musulmán denominado Saad ben Malic, situado junto a la Puerta de Elvira, en tales días en trance de desaparición.

En las páginas siguientes, en unas interesantes fotografías realizadas desde el Colegio de la Presentación podemos apreciar en uno de los muros del Monasterio lápidas con inscripciones árabes, son las que proceden de este cementerio de Puerta Elvira.

Parece que la actual portada del Hospital de San Juan de Dios perteneció a la primitiva del monasterio de San Jerónimo, aunque adaptándose a la forma actual, obra de Cristóbal de Vílchez.

Pero el lugar no les era grato, uno de los monjes, Fray Gonzalo de Frías, en un escrito al arzobispo le dice: pulgas, sabandijas e insectos abundan en demasía, tanto que les impiden comer, dormir, decir misa y orar a los monjes, $n i$ aún les dejaban un instante de reposo y no parecian frailes de San Jerónimo sino de San Lázaro, según estaban de lacerados y mordidos.

Dolidos los Reyes Católicos le dieron otro terreno cercano, conocido por Dar Ibn Murdi, en el que había una mezquita o ermita, que había sido habitada por un moro santo, denominada ermita del Quemado, en recuerdo de haber sido quemado tres veces y en la última haber perecido. Este será el lugar definitivo para el actual monasterio.

\footnotetext{
${ }^{8}$ Sigüenza f.J. [1909], documento citado por Colina Murguía [1986], p. 8.
} 

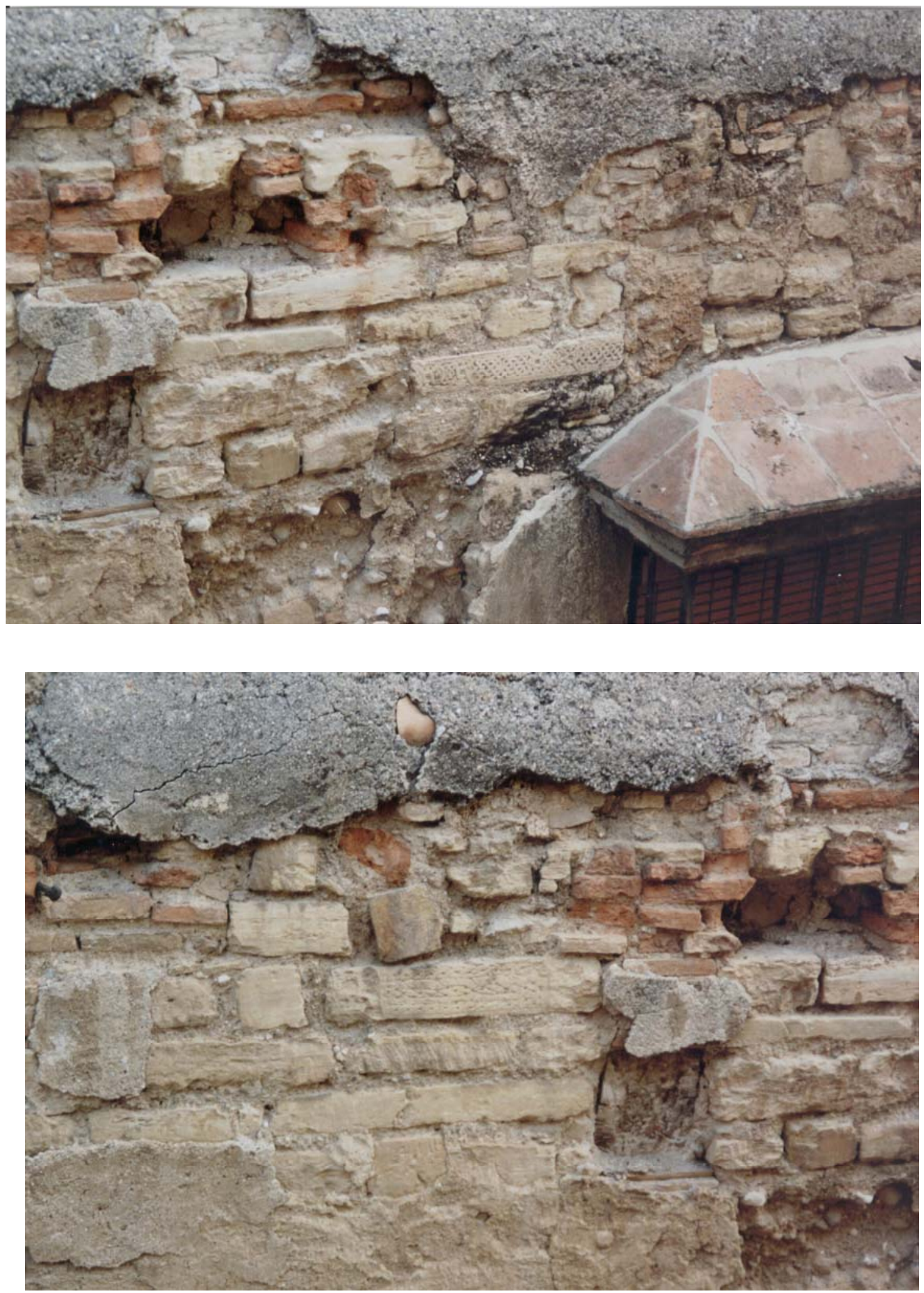

Detalles del muro suroeste del Monasterio de San Jerónimo. 


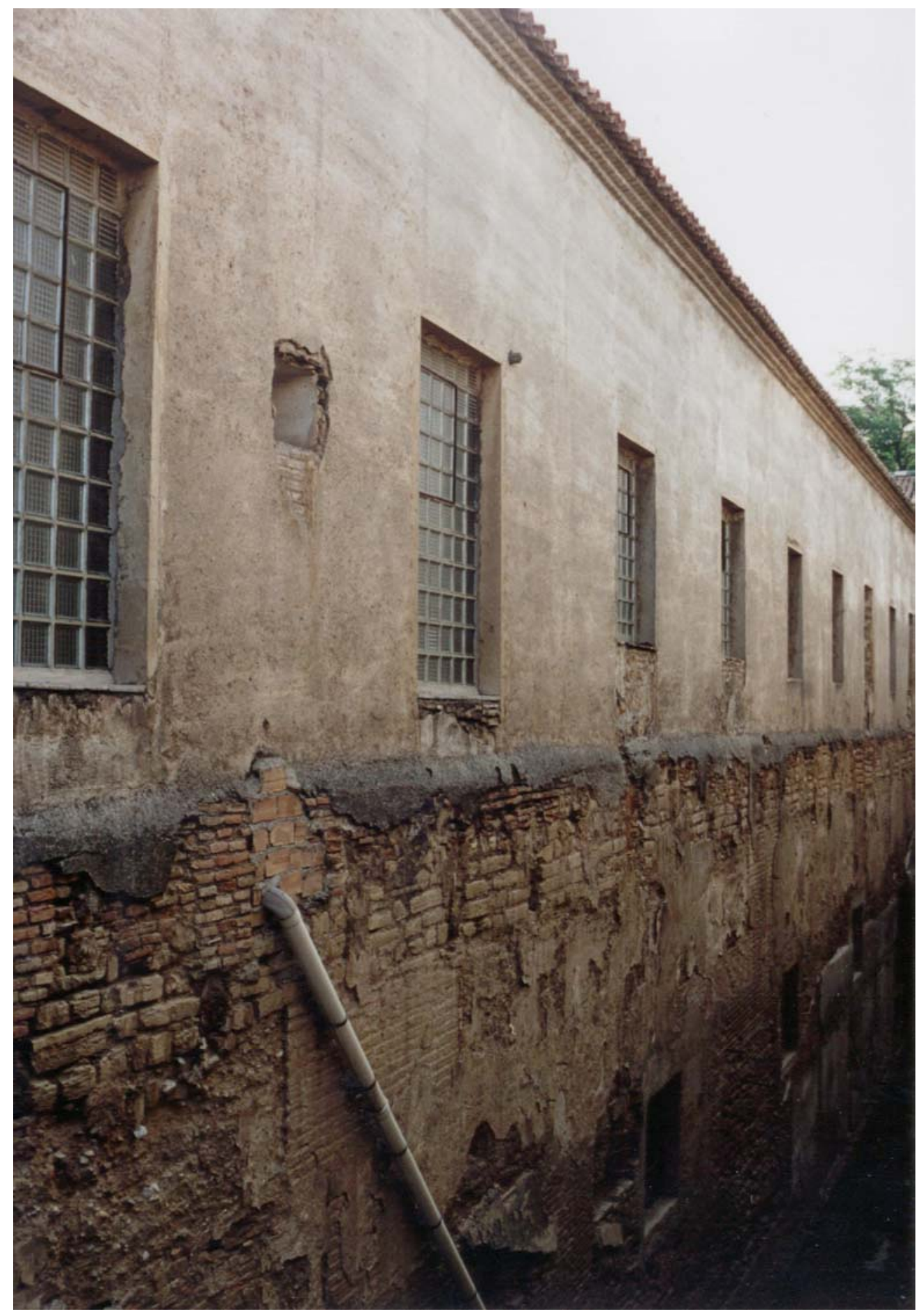

Muro suroeste del Monasterio de San Jerónimo. 
Se desconoce la fecha exacta de su construcción, aunque si que sabemos que es a partir del año 1521 cuando la primera de comunidad de monjes jerónimos comienza a empieza a habitarlo, según el historiador Fray José de Sigüenza los religiosos que llegaron para la fundación fueron los siguientes:

- Prior Fray Diego de Madrigal, profesor de El Parral.

- Vicario Fray Pedro de Ecija, profesor de San Bartolomé de Lupiana y Nuestra Señora de Guadalupe.

- Fray Rodrigo de Mondragón.

- Fray Hernando de Jaén.

- Fray Cristóbal de Valfermoso.

- Fray Gonzalo de Frías, profesor de El Parral y predicador del monasterio de El Paso.

- Fray Gonzalo de Belmonte, profesor de Monte Mar.

- Fray Jerónimo de la Torre, profesor de Monte Mar.

- Fray Francisco de Cuenca, profesor de San Leonardo.

- Fray Gonzalo de Matute, profesor de Estella.

- Fray Fernando de Coca, profesor de Villaviciosa.

- Fray García de Guadalajara.

- Fray Juan de Jaén, profesor de El Parral.

- Fray Miguel de Cásar, profesor de Guadalupe.

- Fray Luis de Jaén, profesor de Guadalupe?

En cuanto a la iglesia, ya en 1513 se estaba trabajando en ella, aunque oficialmente la primera piedra no fue puesta hasta el 5 de noviembre de 1519 , con la bendición del obispo Mondoñedo, presidente de la Real Chancilleria, la iglesia se levantó bajo la advocación de Nuestra Señora de la Concepción.

No conocemos al tracista, aunque algunos autores creen ver la mano del arquitecto real Enrique Egas.

\footnotetext{
${ }^{9}$ Colina Munguía, S. [1985], pp.8-9.
} 
Fue en 1523 cuando el emperador Carlos V accedió a la petición de Dña. María Manrique, viuda del Gran Capitán y Duquesa de Sesa y Terranova, quien quería obtener la Capilla para enterramiento de su marido y de sus descendientes.

Así, Valladar recoge lo siguiente: "En 1523, por cédula real de D. Carlos emperador y rey de Alemania y Doña Juana, su madre, como sucesores de los Católicos Reyes D. Fernando y $D .{ }^{a}$ Isabel, fundadores del patronazgo del monasterio del Señor San Jerónimo de la ciudad de Granada, dieron "gracia y facultad" a la ilustre Sra. D. ${ }^{a}$ María Manrique, duquesa de Terranova, viuda de aquel insigne Caudillo, para que "de voluntad y consentimiento" del Prior y Convento del dicho Monasterio de San Jerónimo, pudiera dicha D. ${ }^{a}$ María "ó los herederos o sucesores del dicho Gran Capitán" y los de ella, acabar de reedificar la capilla mayor del referido monasterio, y pasar el cuerpo del Gran Capitán, desde la iglesia de San Francisco, donde estaba depositado, á la de San Jerónimo y sepultarle en la capilla mayor de él; "la qual podais dexar y dotar en ella-dice la cédula-las memorias que á vos bien visto fuere; pues Nos vos hazemos merced della como patrones que somos del dicho monesterio como dicho es; y queremos y mandamos y es nuestra merced y voluntad que agora ni en ningún tiempo para siempre jamás se entierre ni pueda enterrar en la dicha capilla otra persona alguna de ninguna condición y estado, preeminencia ó calidad”...excepto la duquesa.

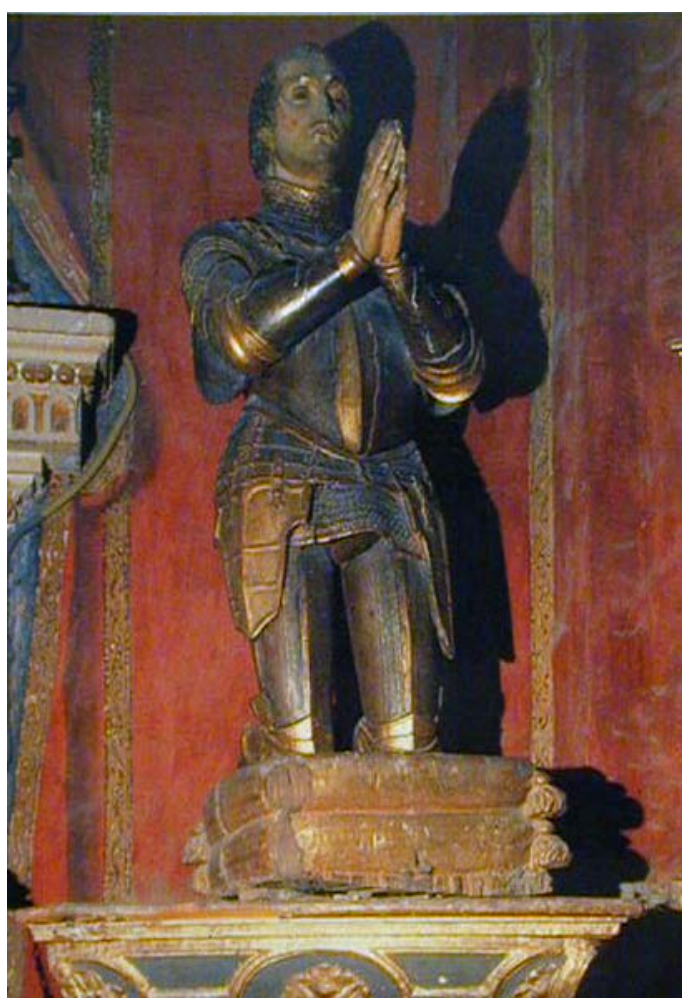

En cumplimiento de la cédula referida, en 15 de Abril de 1525, el contador de la Duquesa señor Juan Franco, debidamente autorizado, convino con el Prior y frailes del Monasterio ciertos capitulos, entre los que resultan que se concedió derecho de enterramiento a los hijos y sucesores de los Duques; que en las vigilias y responsos asistan los frailes con cirios encendidos sobre las sepulturas y que la donación de dineros hecha por la Sra. Duquesa fuera para dote de la Capilla, Capellanías, Misas, Aniversarios, vigilias, fiestas religiosas y memorias y por el trabajo de los ministros.

Este convenio fue confirmado $y$ ratificado en 29 de Agosto de 1553 por el Duque de Sessa, nieto y heredero de la D. ${ }^{a}$ Maria Manrique, fundadora del El Gran Capitán

${ }^{10}$ Valladar, F. [2000], pp.221-222. 
Carlos V se la entregó a cambio de la obligación por parte de Dña. María de terminar la iglesia y dotarla de retablo, reja y túmulos. Esto se formalizo en el año 1525, y las obras fueron encargadas a Jacobo Florentino, quien murió en 1526, por lo que las obras se encomendaron a Diego de Siloé en 1528, la Capilla mayor se cerró el 22 de marzo de 1543. Al mismo tiempo Siloé trabajaba en la decoración de los claustros del monasterio realizando varias portadas, aunque no terminó hasta el final el encargo ya que surgieron diferencias entre él y el Duque de Sesa, nieto del Gran Capitán, quien lo despidió en 1548, pagándole sólo el salario correspondiente hasta 1543.

Unos años después de acabarse la capilla mayor, 1552, se trasladan en cortejo fúnebre desde el convento de San Francisco Casa Grande los restos del Gran Capitán, así como los de Dña. Elvira y D. Luís Fernández de Cordova, traídos desde Italia, donde habían muerto (él en Sesa en 1524 y ella en Roma en 1526), también los cuerpos de sus dos hijos pequeños, los de Dña. María de Guzmán, su primera esposa, los de Dña. Beatriz de Figueroa, su hija, y los de Dña. María Manrique. "El traslado tuvo gran solemnidad, asistiendo la Cruz de la Iglesia Mayor, 450 religiosos; los Capellanes reales; el Cabildo con tres capillas: la Real, la del Duque y la Mayor tras ocho cajas, el caballero de Jaén Juan Peláez de Berrio, soldado en las guerras de Nápoles y el primero que entró en Castelnovo, el cual llevaba el estoque del Gran Capitán, cuya cruz, manzana y empuñadura eran de oro y plata, labradas a martillo. Seguía la presidencia con todos los estandartes y, detrás, los caballeros de Córdoba y su tierra y los de Granada, presidido por el Marqués de Cerralbo. En la Plaza Nueva, Iglesia Mayor y San Jerónimo, se colocaron tribunas para descanso de la comitiva y el poeta Juan Latino dedicó una composición a este traslado". ${ }^{11}$

En el año 1568 el nieto del Gran Capitán, consigue del rey Felipe II, para completar la decoración, la cesión al Monasterio del cortijo de Ansola que correspondía a su mayorazgo, obligándose a los monjes a hacer con sus rentas el retablo, reja y solería, y los sepulcros de D. Gonzalo y de Dña. María. ${ }^{12}$ El monasterio va a servir para enterramiento de grandes e importantes familias, como luego veremos.

La iglesia se completará con la decoración a base de frescos que en 1723 realiza Juan de Medina.

Los monjes habitaron este monasterio desde 1521 hasta agosto de 1835 , año en que la ley de la Desamortización arruinó el monasterio y expulsó a los monjes. Aunque el peor momento vivido por el monasterio fue durante la invasión napoleónica.

Los monjes abandonaron el monasterio el día antes de la entrada de los franceses en la ciudad, situación que fue aprovechada por una muchedumbre que lo saqueó. Esta labor la continuaron las tropas francesas, que inmediatamente

${ }^{11}$ Gallego y Burín, A. [1996], p. 326.

${ }^{12}$ Gallego y Burín, A. [1996], p. 284. 
destinaron el edificio a cuartel, ya que en él encontraron una inmejorable ubicación, y una obra sólida y espaciosa. A los pocos días de haber sido ocupada la ciudad unos comisionados de José Miguel de Asanza, comisario regio nombrado por los franceses, recorrieron el monasterio para realizar un inventario, la situación era desoladora, terminaba su informe advirtiendo:

[Es] indispensable providenciar el auxilio de quatro zentinelas militares, que impidan el que la demás tropa se interne dentro del conbento, a lo menos en las piezas donde existen los enseres, pues estando yo arreglando los efectos para el inventario, handan por medio de nosotros los soldados escogiendo y tomando lo que les parece". ${ }^{13}$

La iglesia fue saqueada y convertida en granero por las tropas, las rejas se fundieron para hacer balas, la Sacristía se destruyó para aprovechar su madera, las tumbas se profanaron, sobre todo la del Gran Capitán en venganza por sus triunfos en la lucha contra los franceses. Se demolieron los dos cuerpos superiores de la torre de la iglesia, utilizando los sillares para construir el nuevo puente Verde, llamado puente de Sebastiani, "un cantero granadino presentó al Comité cantonal un proyecto de demolición completa de la iglesia, para que los fuertes sillares de sus bóvedas y muros se invirtieran en terminar la cubierta del río Darro..."

Al retirarse los franceses las tropas españolas destinaron también el monasterio a cuartel y algunas dependencias a cárcel. Cuando la comisión dirigida por José María Jaime se persone para elaborar un inventario no encontrará nada de interés. Esta lamentable situación fue la que se encontraron los monjes cuando regresaron al edificio.

La comunidad religiosa será exclaustrada durante el Trienio Liberal y los militares vuelven a interesarse por el edificio, así el comandante general del $9^{\circ}$ distrito lo solicitó para crear una academia militar. Pero será en el 30 de agosto de 1835 cuando se produzca la exclaustración definitiva, en ese momento la comunidad contaba con 22 monjes. De nuevo, aprovechando la situación "el populacho robó y destruyó todo. Hasta los huesos del Gran Capitán y de su esposa fueron desenterrados y esparcidos". ${ }^{15}$

El monasterio fue convertido en cuartel de caballería, con carácter provisional, a finales de 1835 , función que acabaría siendo definitiva pese a que el edificio no era de propiedad militar. La iglesia se destinó a ayuda de la parroquia de los Santos Justo y Pastor con el nombre de la Concepción, aunque permaneció cerrada y a cargo de la Academia de Bellas Artes hasta que en octubre de 1842 el jefe político pidió las llaves para reabrirla al culto.

\footnotetext{
13 "Diligencias e Inbentario gral. de la Platta Muebles y demás effectos que se encontaron en el Monasterio de S. Jerónimo" Documento citado por Gallego y Burín, A. pp. 71-72.

${ }^{14}$ Valladar, F. [1906], p. 8.

${ }^{15}$ Ford, R. [1951], p. 112.
} 

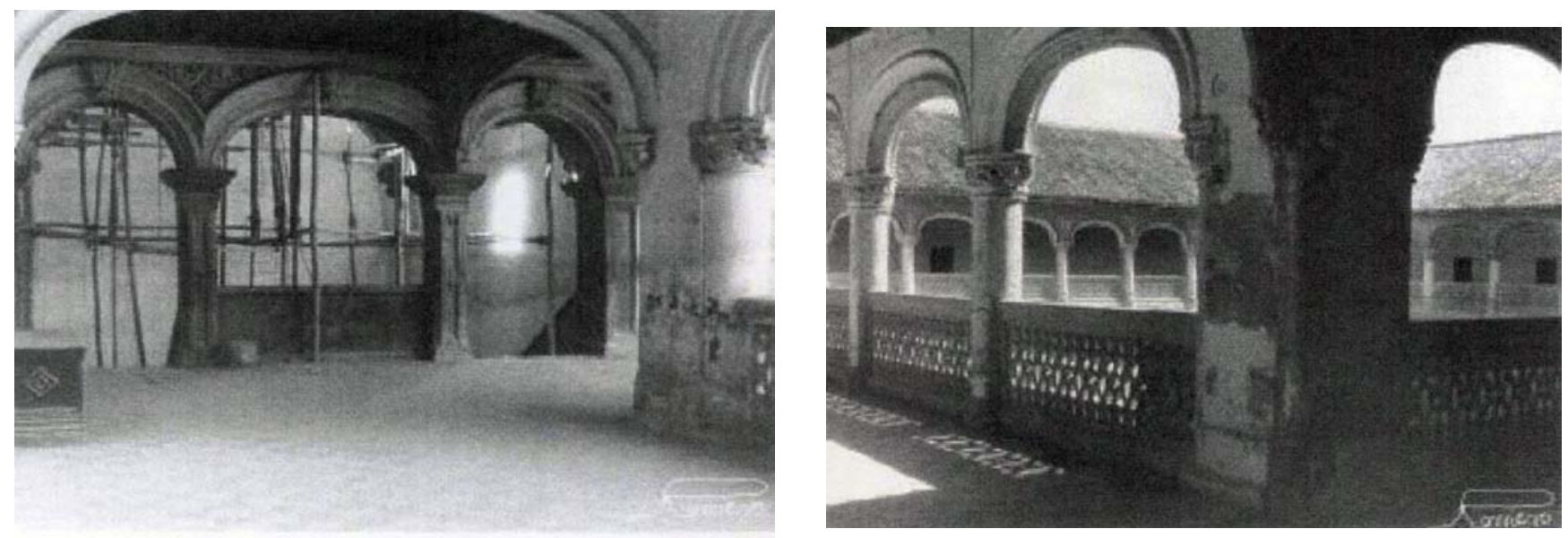

Parte superior de la escalera y parte superior del claustro principal (antes de la restauración). Museo Casa de los Tiros.

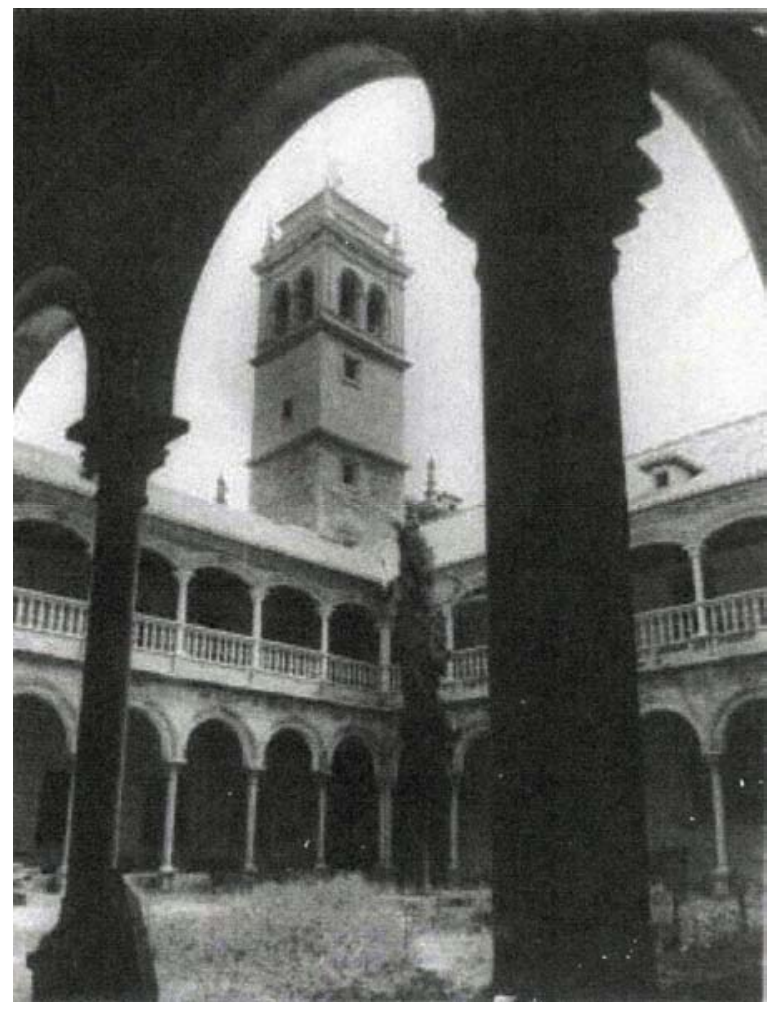

Claustro principal, una vez reconstruida la torre. Museo Casa de los Tiros. 

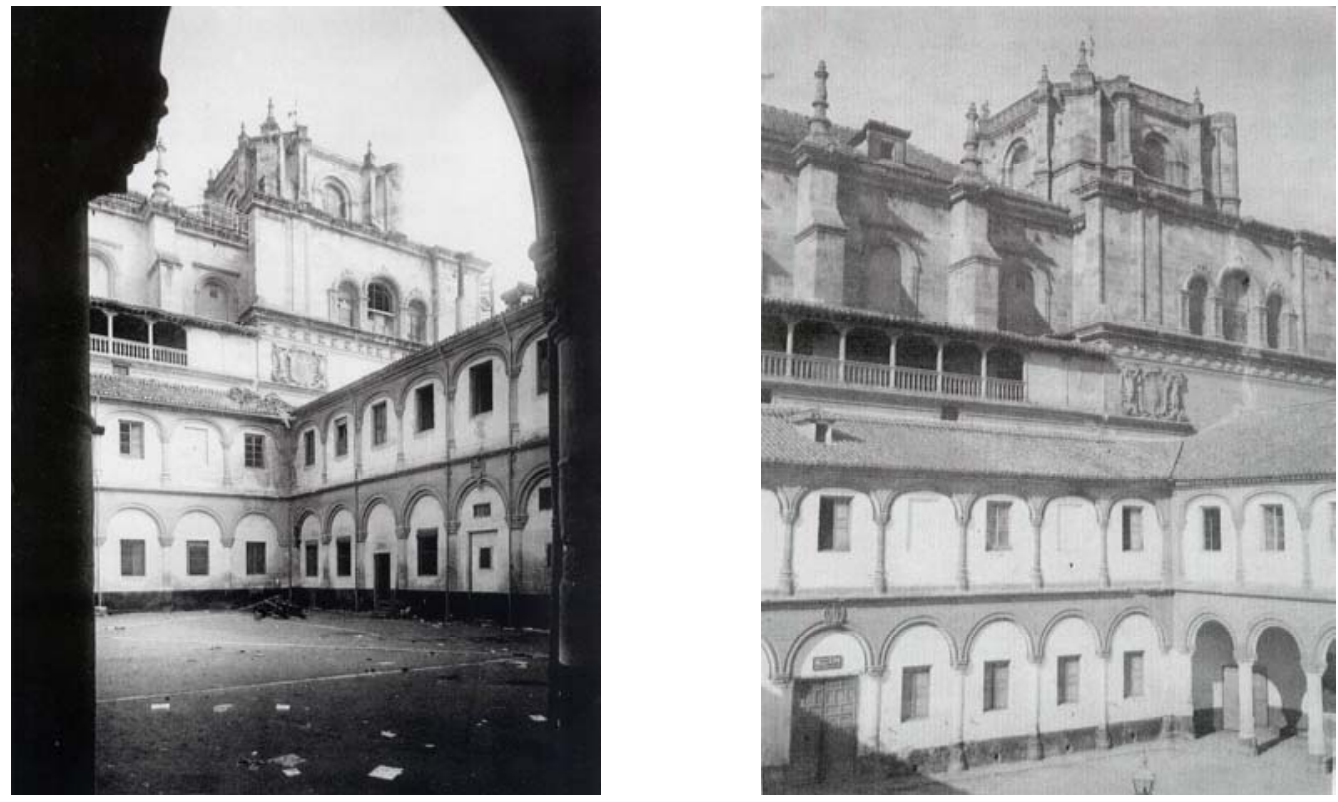

Dos imágenes del claustro principal cuando tenía uso militar. Museo Casa de los Tiros.

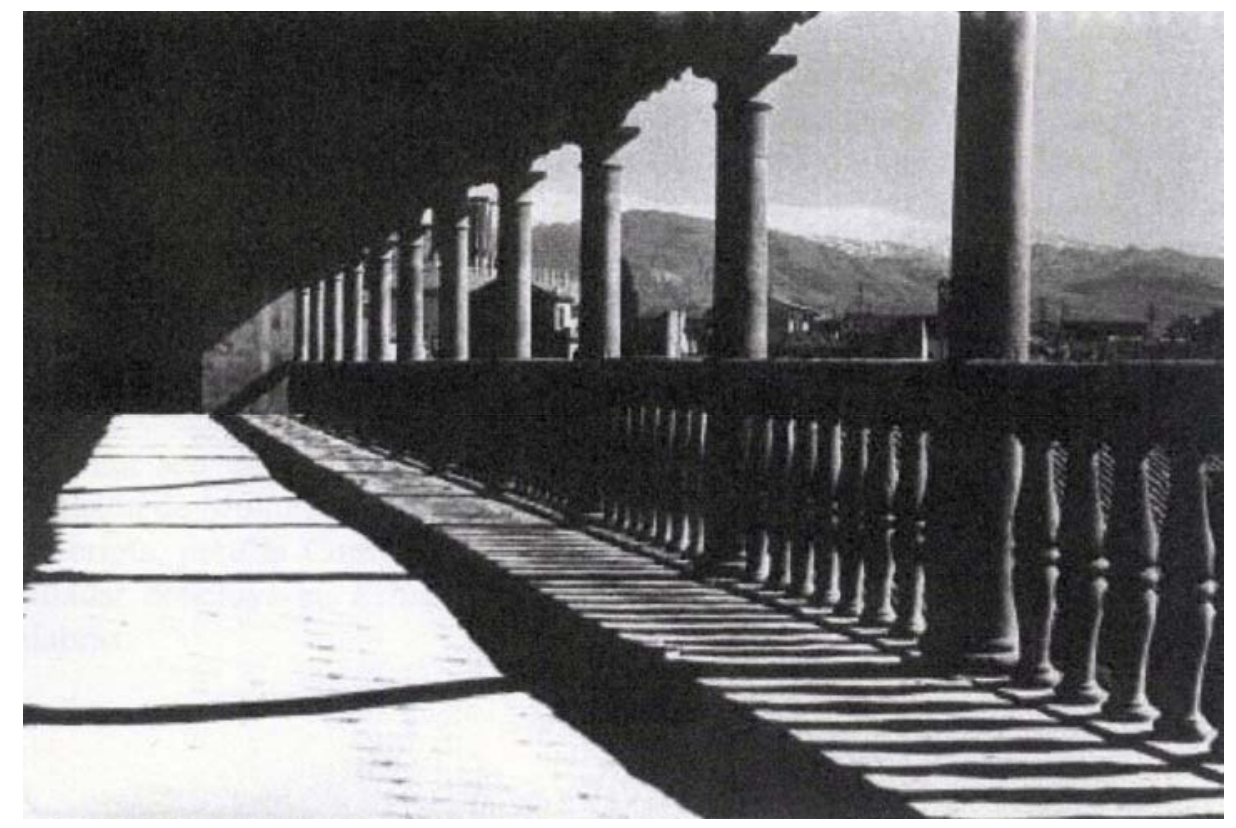

Vistas de Granada, desde el Solarium o terraza de convalecientes. Museo Casa de los Tiros. 
El edificio se iba degradando progresivamente mientras que la Comisión de Monumentos por lo que estaba realmente preocupada era por la recuperación de los restos del Gran Capitán. Estos estaban en manos de un particular y en el año 1857 volvieron solemnemente a la bóveda del presbiterio, después de haberse hecho algunas obras de restauración en el templo, aunque en 1869 se obligó a trasladar los restos a la iglesia de San Francisco en Madrid, lugar destinado a la construcción de un panteón de los hombres ilustres de España, idea que se abandona y los restos de Gonzalo Fernández de Córdova vuelven a su enterramiento

Se propuso después su utilización para hospital de repatriados, hasta que en 1875 la Comisión de Monumentos tomó la iniciativa y Manuel Gómez-Moreno González solicitó al ministro de Fomento y Comunicaciones que el templo fuera declarado monumento nacional, la declaración se hizo por Real Orden de 24 de mayo de 1877 con el título de exceptuado de la venta de Bienes Nacionales, como Monumento histórico y artístico de la Nación.

Para su reapertura al culto las autoridades eclesiásticas lo cedieron a los padres redentoristas, aunque permanecieron poco tiempo en él ya que el edificio presentaba señales de ruina y hubo que cerrarlo. "La noche del 22 de diciembre de 1883 una dovela del arco de una ventana se desprendió produciendo daños en las techumbres del claustro inmediato. Este hecho animará a la Comisión de Monumentos a encargar unas obras de restauración a Mariano Contreras, primero, y más tarde a Juan Monserrat, aunque las obras se irán retrasando y no se empezará a trabajar activamente hasta 1900"16. En 1904 vuelve a abrirse la iglesia al culto, aunque el estado seguía siendo penoso, así "los tejados que cubren las dos series de capillas laterales amenazan próxima e inminente ruina y las bóvedas de la parte del ábside y del coro presentan un estado de ruina inminente parcial". ${ }^{17}$

En 1912 se agravaba la situación por lo que la Comisión de Monumentos comenzó a preocuparse por los objetos artísticos que la iglesia albergaba. Fue en estos momentos cuando la prensa granadina se hizo eco del problema. En 1913 se instalaron unos andamios pero hasta 1916 no se emprenden las obras de restauración bajo la dirección del arquitecto Fernando Wilhemi, pero transcurridos unos años parece que el estado de la iglesia no había mejorado mucho, Andrés Gutiérrez Fernández, visitador de monumentos nacionales, tras visitarlo el 21 de octubre de 1922 relata lo siguiente:

"Nótase, en primer término, el lamentable abandono en que se tiene la explanada que da acceso a la Iglesia. Montones de cascajo, por unas partes, trozos de piedras artísticamente labradas, por otro; profusión de trapos puestos allí a secar por lavanderas del barrio [...] varios niños tirando piedras a unas cuentas

\footnotetext{
${ }^{16}$ Archivo Histórico Provincial de Granada, caja 37, 2 2 parte, carpeta H. Documento citado por Barrios Rozúa, J. M. [1998], p.p.535-536.

${ }^{17}$ Archivo Histórico Provincial de Granada, caja 37, $2^{\mathrm{a}}$ parte, carpeta H. Documento citado por Barrios Rozúa, J. M. [1998], p.p.535-536.
} 
palomas que en los ventanales del templo se posaron, y una casilla miserable construida frente a la puerta del grandioso monumento [...].

En el templo hace más de un año que no se trabaja y observase que hay alli obras de verdadera urgencia, como las que se refieren a la consolidación de la bóveda central.

Por las grandes ventanas que dan al centro del crucero, desprovistas de cristales penetran las aguas pluviales, palomas, lechuzas, murciélagos y hasta ratas, ocasionando deterioro en las pinturas y en los relieves y medallones que decoran los muros y dejando el pavimento de la Iglesia en un estado de suciedad harto lamentable.

La losa de mármol que hay sobre la cripta donde reposan los restos del Gran Capitán está partida por varios extremos" ${ }^{18}$.

Mientras el monasterio seguía teniendo el uso de cuartel de caballería, se realizaron algunas obras, así en el año 1890 una de las naves del segundo patio se hundió y su reparación causó diferentes opiniones, Gómez-Moreno señalaba que "es merecedor de aplauso el celo y cultura con que los jefes militares atienden a la conservación del edificio en toda su integridad, de lo cual es prueba el desencalado que ahora se está efectuando de las columnas y portadas". ${ }^{19}$ Paula Valladar en cambio se quejaba de que los militares no habían dudado en derribar los restos que quedaban de la antigua sacristía, "las autoridades militares proyectaron una reforma en el convento, convertido desde hace años en cuartel de caballería. Por motivo de estas obras, que la Comisión creo desconoce como proyecto y ejecución, se han derribado los restos de parte de la antigua sacristia", ${ }^{20}$

Francisco de Paula Valladar junto con Manuel de Góngora presentaron a la Comisión de Monumentos un informa, tras haber investigado y estudiado el templo y la cripta, pero la Comisión hizo caso omiso a sus recomendaciones, por lo que Valladar concluye su Estudio histórico sobre San Jerónimo, en 1906, con estas palabras:

"Por erróneo criterio, la Comisión no hizo presentes sus deberes ni al proyectarse las obras militares en construcción, ni al hacerse entrega del templo, que es monumento nacional, á los PP. Redentoristas. La legislación referente á cuestiones artísticas, resuelve de modo definitivo que en las iglesias, sean ó no monumentos históricos, no pueden efectuarse obras de ninguna clase sin la intervención é inspección de las Comisiones y la Academia; legislación que no se cumple en Granada, como es fácil de comprobar aun en épocas muy recientes (Además del Concordato de 17 de Octubre de 1851 y del Convenio de 4 de Abril de

\footnotetext{
${ }^{18}$ Archivo Histórico Provincial de Granada, caja 37, $2^{\mathrm{a}}$ parte, carpeta H. Documento citado por Barrios Rozúa, J. M. [1998], p.p.535-536.

${ }^{19}$ Gómez-Moreno Martínez, M. [1994], p.377

${ }^{20}$ Valladar, F. [1906], pp.13-14.
} 
1860, hay un sin número de Reales órdenes y decretos referentes á tan interesante asunto).

Como tantas veces, por su parte, aunque para todos sus gastos de personal de secretaría y dependientes, adquisición de libros, obras y objetos arqueológicos, investigaciones y estudios, dispone de la enorme suma de mil pesetas anuales, pues la Diputación provincial suprimió otras mil que con aquéllas formaban la pingüe dotación que la Comisión encargada de velar por las artes y la arqueología de toda la provincia, -proyecta; aunque sea costeada con el dinero de sus individuos, colocar la reja en la tumba del héroe y reparar las cajas de madera y zinc que guardan las cenizas de aquél. Lo demás, la ruina del muro que comunica con lo que fue sacristía, la que amenaza la notable bóveda plana sobre que está situado el coro, las goteras, las investigaciones, la cubierta de este fresco que pronto desaparecerá, lo que la iglesia necesita, no puede hacerse con los recursos de los individuos de la Comisión, ni con el espléndido haber del que disfruta. ¿No habrá nadie que se interese porque la ruina del hermoso templo se contenga?..."

El Boletín Oficial de la Provincia publicó el 14 de junio de 1923 la subasta de obras para la ampliación del cuartel de San Jerónimo.

En 1927 el edificio volvió a sufrir otro lamentable suceso, esta vez un incendio que destruyó los artesonados de la escalera y del claustro pequeño, cuyo piso principal quedó prácticamente arruinado.

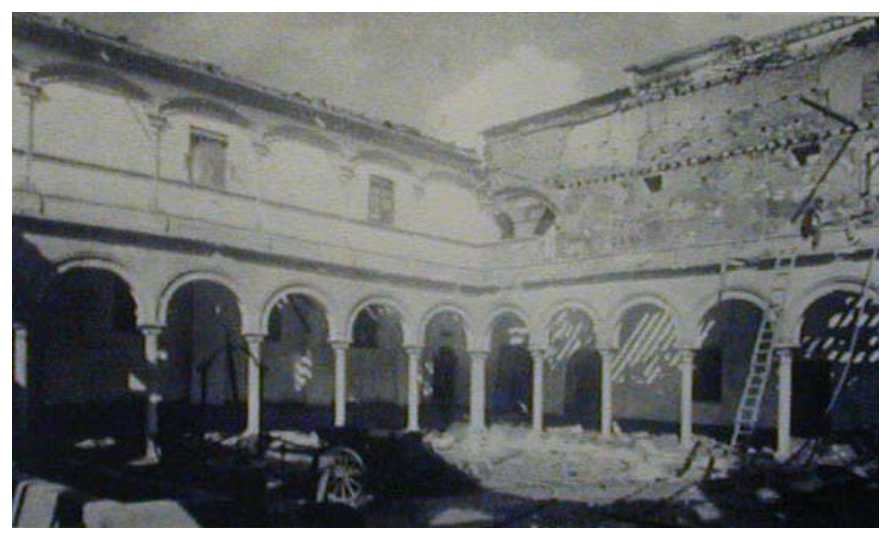

Imagen del claustro tras el incendio de 1927.

\footnotetext{
${ }^{21}$ Valladar, F. [1906], pp.21-22.
} 
Los militares continuaron en él hasta que el 3 de junio de 1931 se declaró el monasterio Monumento arquitectónico y artístico Nacional. Pero las obras de restauración tuvieron que esperar aún un tiempo, no fue hasta 1958 cuando se acometieron las labores de limpieza y la reconstrucción del claustro incendiado no se comenzó hasta el año 1962. La torre empezó a reedificarse en 1963, cuando la Dirección General de Bellas Artes destinó 599.000 pesetas para esta labor, concluyéndose en 1971.

El monasterio se cedió en usufructo a la Orden Jerónima por los decretos de 20 de septiembre de 1962 y 4 de marzo de 1965, y la ley de 22 de junio de 1967. El 21 de julio de 1973 se les cedió el monasterio y el 26 de enero de 1974 se firmó la escritura de cesión. Gracias al cambio realizado por Sor Cristina de la Cruz Arteaga, Madre superiora del Convento de Santa Paula de Sevilla e hija y heredera de Joaquín de Arteaga, Duque del Infantado, quien cambió el Carmen de los Mártires por el monasterio de San Jerónimo, a los pies de la torre hay una lápida labrada en piedra en la que puede leerse "La restauración de San Jerónimo ha sido fruto del sacrificio de "Los Mártires"”,.

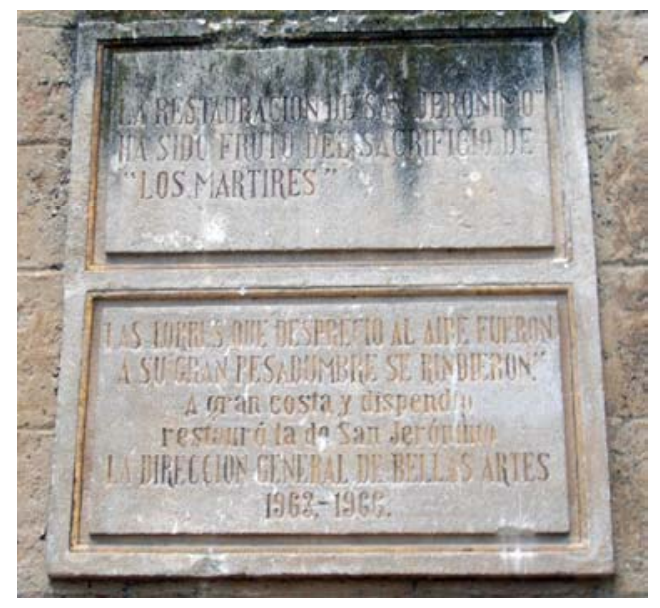

Lápida a los pies de la Torre del Monasterio de San Jerónimo.

La última fase de las obras fueron ya costeadas por la Orden Jerónima. Se completó y embelleció el monasterio con elementos procedentes de otros edificios de la ciudad como la portada y el pilar de la casa prioral de la Cartuja, la portada del Correo Viejo, ventanas de la Calahorra, restos de una casa de la Carrera del Darro, un artesonado del Carmen de los Mártires, rejas antiguas, las gradas de altar de un convento de Sevilla, columnas de un palacio sevillano, etc. En el compás, rehabilitado hace unos años, se instalaron varios elementos arquitectónicos procedentes de edificios desaparecidos.

Desde el 1 de junio de 1973 la actual Comunidad femenina de la Orden Jerónima ocupa el monasterio. 


\section{- Fray Hernando de Talavera y fray Ramiro de Alba.}

Destacaremos en nuestro discurso expositivo la figura de estos dos monjes jerónimos, de gran importancia para la historia eclesiástica de la ciudad de Granada.

\section{- Fray Hernando de Talavera.}

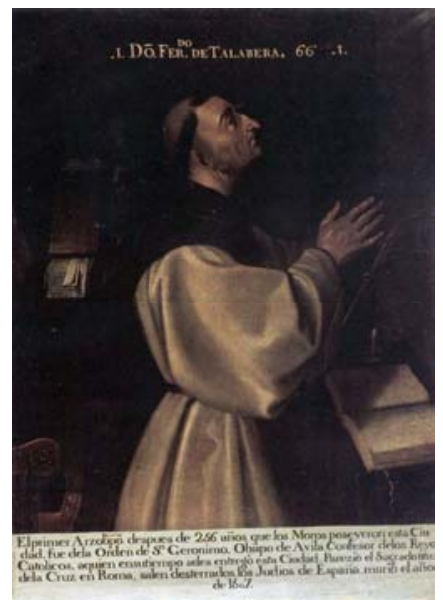

Junto con los Reyes Católicos hay que destacar la figura de fray Hernando de Talavera. Nació en Talavera de la Reina (Toledo) en 1430 o 1431 , de ascendencia judía, algunos autores piensan que tal vez fuera hijo bastardo del primer duque de Alba, don García Álvarez de Toledo.

En 1460 se licenció en Teología, ocupando la cátedra de Filosofía Moral desde 1462 a 1466, momento en el que ingresó en la Orden Jerónima, señera en el movimiento de reforma de la Iglesia, en el año 1466. Fue prior del Monasterio de Nuestra Señora del Prado en Valladolid, durante dieciséis años, hasta que en 1475 fue llamado a ser confesor de la reina Isabel, desde entonces "se convertirá en un personaje esencial, en uno de los más destacados ideólogos, inspiradores e impulsores del Estado moderno español, y la llamada reforma española tuvo en él su origen y su alma mater". ${ }^{22}$

A partir del 2 de enero de 1492, fecha de la entrada de los Reyes Católicos en Granada, fray Hernando se consagró por entero a la organización y gobierno de la iglesia y del Reino de Granada. Fundó el Real Colegio Eclesiástico para formar a los aspirantes al sacerdocio, hizo venir a afamados impresores alemanes como Pegnitzer y Ungot, los que en 1496 editaron el catecismo Breve Summa, escrito por el propio Talavera. Debido a sus buenas relaciones con los judíos y musulmanes fue sospechoso del Tribunal de la Inquisición, pero gracias a la intervención de la reina Isabel, el proceso pudo evitarse. Aunque más tarde, muerta ya la Reina, en 1506 fue procesado de nuevo, se le acusó de tener tratos con moriscos y conversos y de tener ascendencia judía. Estuvo algún tiempo preso y puesto en libertad volvió a Granada, donde murió en 1507.

${ }^{22}$ Del Cerro Bex, V. [2000], p. 515. 


\section{- Fray Pedro Ramiro de Alba.}

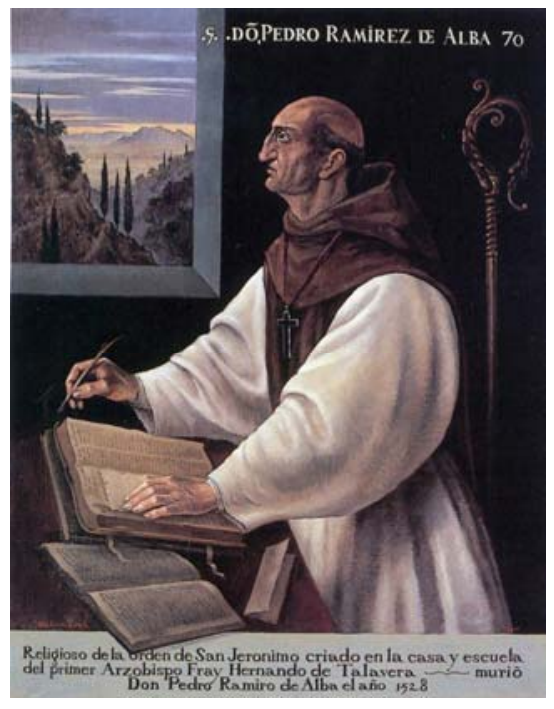

Pedro Ramiro de Alba nació en Alba de Tormes (Salamanca) hacia 1460. Fue elegido prior del Monasterio de San Jerónimo de Granada en el año 1512, gozó de gran fama como uno de los teólogos más destacados de su tiempo.

En 1526, la corte imperial se encuentra en Granada, mientras Carlos V se aloja en la Alhambra, la emperatriz Isabel lo hará en San Jerónimo, siendo su confesor, fray Pedro. La Emperatriz intercederá para que sea nombrado Arzobispo de Granada, fueron pocos lo años que regirá la diócesis de

Granada, pero muy fecundos. Apostó por la formación y la educación como solución a los problemas de la población morisca. Fue fray Pedro, quien puso a Diego de Siloé al frente de las obras de San Jerónimo y más tarde frente a las de la Catedral. "No sería de extrañar que fray Pedro, intentando siempre un retorno de la Iglesia al cristianismo primitivo y a las fuentes de la antigüedad cristiana, tomara partido muy conscientemente por el Renacimiento, en aquel momento identificado no sólo con la Antigüedad pagana, sino muy especialmente con las iglesias paleocristianas de la época de Constantino el Grande". ${ }^{23}$

Murió en 1528, siendo sepultado en la aún mezquita-catedral de la ciudad de Granada junto a su maestro Talavera.

\section{- La escuela de Latín y Música.}

Se construyó en el año 1636, junto al monasterio de San Jerónimo, la escuela de Latín y Música, dependía del monasterio y se accedía a ella a través del compás de éste. Fue fundada por uno de los benefactores del Monasterio, Díaz Sánchez-Dávila. El edificio fue proyectado por Francisco de Potes, uno de los arquitectos que trabajo en el palacio de Carlos V, en el año 1636.

Aunque la estructura original está muy desfigurada, ya que sufrió algunas adaptaciones para instalar viviendas y almacenes en los bajos, y que se encuentra en un estado de ruina, se conservan algunos restos del edificio, así, la arquería baja completa, un patio cuadrado con tres arcos de medio punto en cada lado, con archivoltas molduradas, relieves sencillos en la clave y columnas dóricas, con

\footnotetext{
${ }^{23}$ Lozano Navarro, J.J. [2000], p. 537.
} 
pilastras adosadas en los ángulos. El zaguán y los cenadores tienen una buena viguería de madera, y en el cuerpo alto, de donde arranca la construcción moderna, hay algunos arcos más. La escalera presenta una balaustrada de piedra rematada por jarrones, está cubierta por una bóveda semiesférica con moldura y friso de canecillos, sobre pechinas adornadas con relieves.
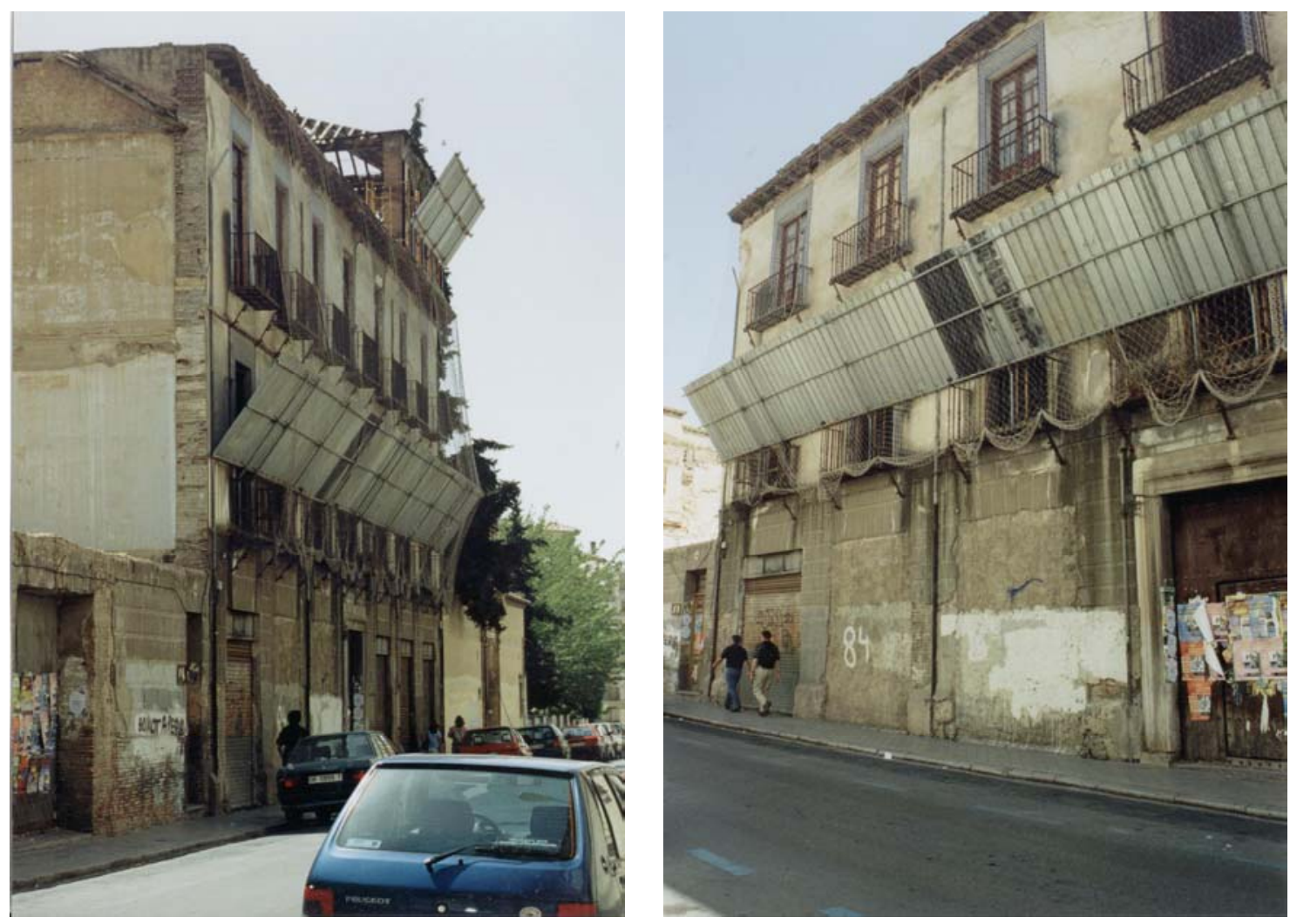

Estado actual de la Escuela de Latín y Música. 


\section{Documentación disciplinar: Historia de la investigación y estado actual.}

Respecto a la bibliografía jerónima destaca sobre todo, la Historia de la Orden Jerónima, escrita por el padre fray José de Sigüenza.

Otros escritos sobre la historia de la Orden son los de fray Francisco de los Santos, Quarta parte de la Historia de la Orden de San Jerónimo (Madrid, 1680); la Quinta parte de la Historia de la Orden Jerónima de fray Francisco Salgado, cuya copia manuscrita se encuentra en el Monasterio de Santa María del Parral en Segovia y la Historia general de la Orden de San Jerónimo de fray Francisco Montalvo (Salamanca, 1704).

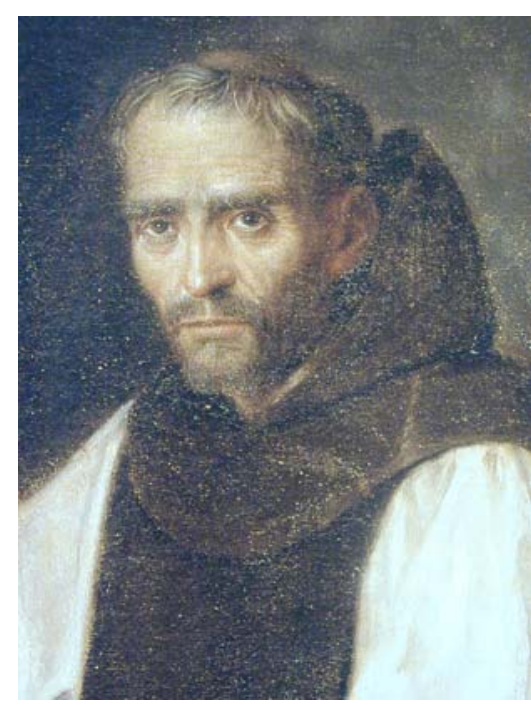

El Padre Sigüenza

Otra obra de referencia para la Orden Jerónima es el discurso Los Gerónimos, leído por Elías Tormo el día 12 de enero de1919 en la Academia de la Historia. En él hace un breve seguimiento de la Orden hasta la Desamortización y facilita al futuro investigador aquellos puntos carentes de estudio en profundidad, instigándole a investigar.

Ya en la actualidad, ha sido el padre fray Ignacio de Madrid, prior del Monasterio de Santa María del Parral, quien ha investigado mucho sobre la Orden, publicando distintos trabajos en los que expone los aspectos históricos y espirituales de la Orden en cada época. y en el contexto de la historia de nuestro país.

Desde el punto de vista espiritual de la Orden Jerónima los estudios son más numerosos, así los de Colombas o D’allerit publicados en Yermo.

Respecto a la arquitectura de la Orden Jerónima, ha sido estudiada por Wilfredo Rincón dentro del trabajo que público sobre la arquitectura monástica junto con Pedro Navascués, Los monasterios españoles.

Existe también un libro, Los monasterios jerónimos, de José Antonio Ruiz Hernando, una obra muy general publicada en 1997, sobre los monasterios jerónimos que existieron en España, hace una relación de todos ellos con una somera descripción, centrándose en su arquitectura.

La relación de la Corona con la arquitectura de los monasterios jerónimos ha sido estudiada por Fernando Chueca Gotilla en su estudio Casa reales en 
monasterios y conventos españoles, aunque se centra sobre todo en los monasterios de Guadalupe y el Escorial.

Existen además estudios parciales sobre algunos conventos y monasterios, en especial sobre el Monasterio de San Lorenzo del Escorial y sobre el Monasterio de Guadalupe, pero no existe un estudio monográfico que analice en profundidad y dé una visión de conjunto de la arquitectura de todos los monasterios jerónimos que existieron en España, con el objeto de aclarar si llegó a existir un modelo jerónimo de monasterio.

Sobre los bienes muebles de la Orden, fue en 1999 cuando Isabel Mateo Gómez, José María Prados García y Amelia López-Yarto Elizalde publicaron el interesante trabajo El Arte de la Orden Jerónima. Es un estudio completo que abarca la aportación estética de los jerónimos a la Historia del Arte, valorando sus propios criterios y la aportación que a los mismos impusieron sus protectores.

Centrándonos ya en el Monasterio de San Jerónimo de Granada, las primeras descripciones que encontramos son la de Pedraza en su Historia Eclesiástica (capítulo LVI, f. ${ }^{\circ} 174$ vto.); la del Padre Lachica en sus Gazetillas (papel XIX, 13 de agosto 1764) aunque estas son meras referencias, si realiza una interesante descripción del Monasterio H. de Jorquera en sus Anales de Granada (tomo I, cap.34.), descripción que hemos leído en la trascripción que de ella hace Francisco de Paula Valladar en 1906.

Otras referencias a San Jerónimo de Granada son las que realizaron los viajeros en sus descripciones de la ciudad de Granada, podemos señalar la del embajador Andrea Navagiero en el siglo XVI y las posteriores de Lafuente o Ford entre otros. No hay que olvidar tampoco las guías de la ciudad de Granada, Valladar, Seco de Lucena, Gómez Moreno o Gallego Burín son algunos de los que han descrito el Monasterio y la Iglesia.

Existe también documentación sobre San Jerónimo en la prensa. A principios del siglo XIX, fueron varios granadinos los que se preocuparon por el Monasterio, algunos llamando la atención de la Comisión de Monumentos a través de la prensa, así fueron muchos los escritos realizados por Manuel Góngora, Manuel Gómez Moreno y sobre todo, Francisco de Paula Valladar, la mayoría de ellos publicados en la revista Alhambra, que dirigía Valladar, y otros en periódicos como Patria o El Defensor. Y ya en el siglo XX los artículos publicados, en la década de los sesenta y en la de los setenta, en Ideal por Checa, Lachica o Colina Munguía, entre otros.

No debemos dejar a un lado, otro tipo de documentación que ayuda a comprender la evolución y la imagen del Monasterio de San Jerónimo en la ciudad. La cartografía histórica y los dibujos, litografías, grabados y lienzos de Granada en los que puede apreciarse el Monasterio. (Nosotros hemos hecho una selección e incluimos en el apéndice, algunos de ellos). 
Saturnino Colina Munguía, publicó una guía sobre el Monasterio (segundo premio de Turismo Everest, 1985), única obra general sobre San Jerónimo, pero quizás demasiado general ya que está dirigida al sector turístico.

Estudios parciales del Monasterio de San Jerónimo han sido los de Barrios Rozúa, en su interesante estudio sobre los edificios desamortizados en Granada. Los de José Castillo Ruiz sobre el entorno de San Jerónimo en su obra $E l$ entorno de los Bienes Inmuebles de Interés Cultural. Las portadas y otros elementos arquitectónicos han sido estudiados por José Manuel Gómez-Moreno Calera en La arquitectura religiosa granadina en la crisis del Renacimiento (15601650). Y el retablo, en cuanto a su significado iconográfico, ha sido estudiado por Francisco Javier Martínez Medina. Otros trabajos son los de Rafael López Guzmán en El Renacimiento en Granada o los de Ignacio Henares Cuellar, éste último realiza un interesante análisis sobre la importancia urbanística del ábside del Monasterio de San Jerónimo, en el eje eucarístico San Jerónimo-Catedral en Los modelos del Clasicismo y el Humanismo en la Granada Moderna.

En cuanto a las últimas investigaciones, la última sobre el Monasterio de San Jerónimo, ha sido el trabajo de investigación presentado, en septiembre del año 2000 en el Departamento de Historia del Arte de la Universidad de Granada, por Antonio Callejón Peláez y dirigido por el profesor Rafael López Guzmán. Trabajo que ha estudiado en profundidad el programa iconográfico de mujeres ilustres en la iglesia de San Jerónimo de Granada.

En la actualidad tenemos conocimiento de que se están llevando a cabo algunas investigaciones en el departamento de Historia del Arte de la Universidad de Granada sobre el Retablo de la Capilla Mayor de San Jerónimo.

Echamos en falta una monografía del Monasterio de San Jerónimo de Granada, cuyo contenido realizado con gran rigor científico profundice en la historia del edificio, en su arquitectura y en su contenido. Es necesario un estudio que consiga, en los posible, recuperar y reconstruir su patrimonio artístico disperso por la ocupación francesa y por la Desamortización después.

El campo para investigar sobre la Orden Jerónima y sobre el Monasterio de San Jerónimo de Granada, aún está abierto, ya que, como hemos comentado, quedan muchos temas incompletos o sin estudiar de un patrimonio español tan interesante e importante para la comprensión de nuestra historia. 
III. EL CONTENEDOR. 


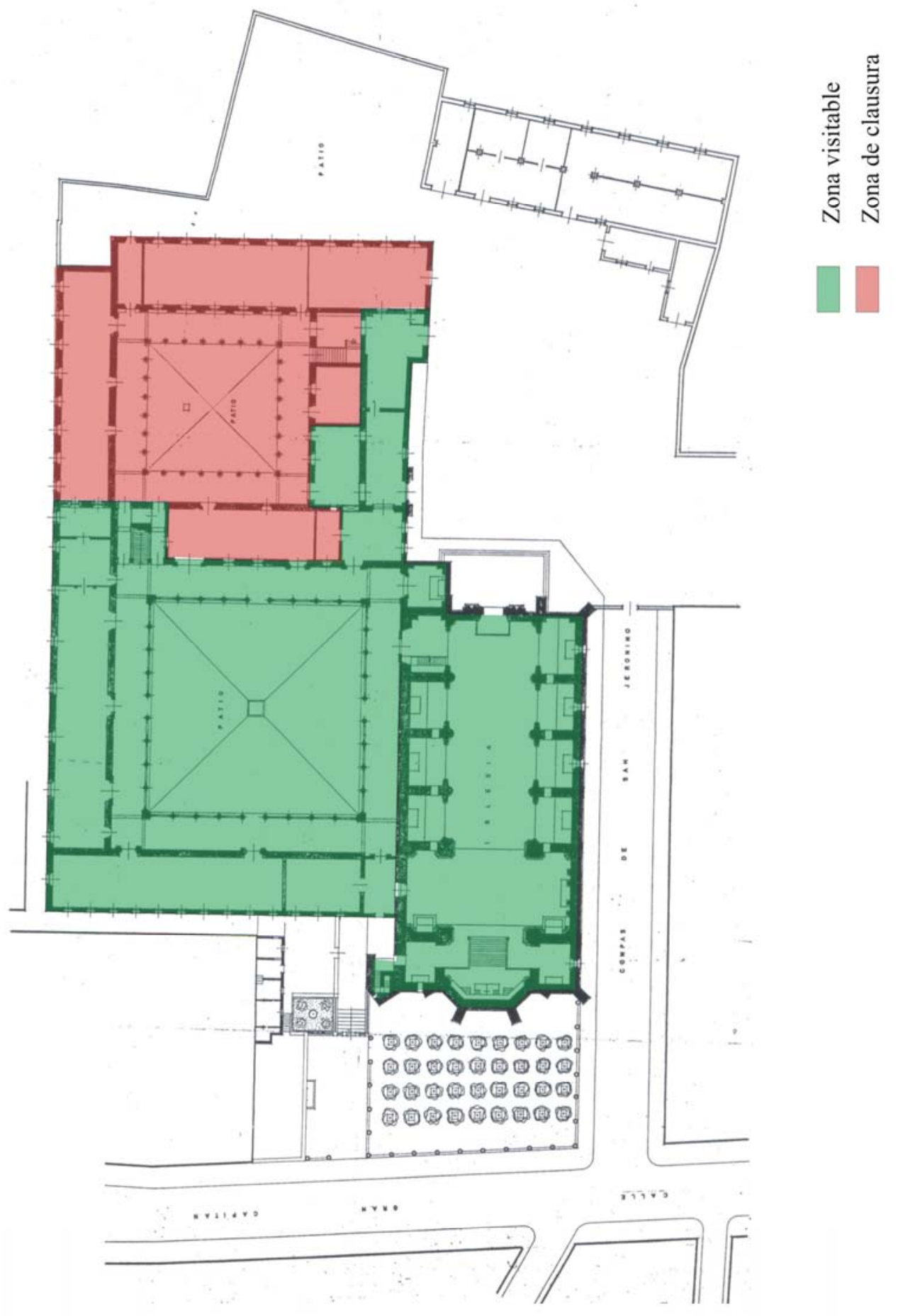

 

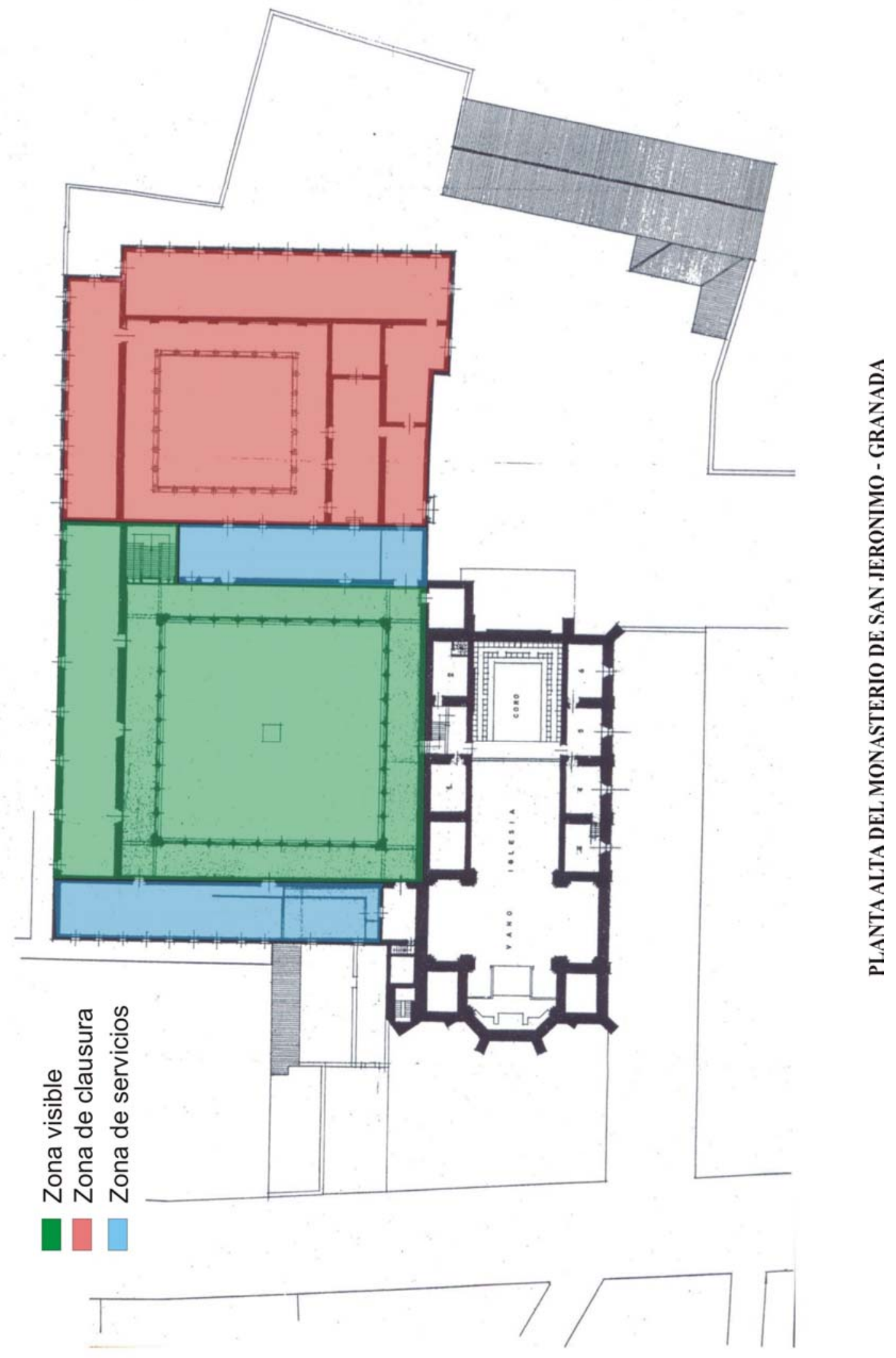


\section{EL CONTENEDOR.}

\section{La condición tutelar del Monasterio y su espacio circundante.}

La declaración del monasterio como monumento histórico-artístico se producirá a finales del siglo XIX, determinada por es estado lamentable en que había quedado tras la ocupación francesa y la exclaustración, como señala el profesor Castillo aparte de la necesidad de recuperar o evitar la ruina de un importante ejemplo de nuestro arte renacentista, será la "oportunidad" histórica de restablecer el contexto arquitectónico donde reposaron los restos de un insigne e ilustre "héroe" nacional, el Gran Capitán Gonzalo Fernández de Córdoba, lo que permitirá la protección y posterior restauración de San Jerónimo ${ }^{24}$.

La primera intervención fue la Real Orden de 15 de enero de 1857, dada por Isabel II y el ministro Nocedal En ésta, tras contemplar el estado en el que se encontraban los restos del Gran Capitán, se disponen una serie de medidas, todas ellas encaminadas a recuperar el rigor artístico y cultural que contextualizaba la tumba.

Con veinte años de diferencia, se da la Real Orden de 24 de mayo de 1887, por la que se declara la Basílica de San Jerónimo como Monumento Nacional y no será hasta el año 1931 cuando el 3 de junio, por un Decreto de Alcalá Zamora, cuando se declare el Cuartel de San Jerónimo como Monumento Artístico Nacional.

El hecho de que la iglesia y el monasterio fueran incorporados al Patrimonio Histórico Español con tanta diferencia en el tiempo provocó que las intervenciones realizadas en estos espacios fueran muy distintas, así en la iglesia se comienza con pequeñas intervenciones, como la reparación de los ventanales que se lleva a cabo por la iniciativa privada del Conde de Antillón, realizándose luego la restauración por el arquitecto Wilhemmi que se concluiría hacía el año 1916. Mientras en el monasterio, se realizaban multitud de reformas y de modificaciones en función de las necesidades de su uso como Cuartel de Caballería.

Pero una vez declarado el Cuartel como monumento histórico comienza la recuperación del monasterio como espacio histórico unitario, en al año 1958 las primeras labores de limpieza y a partir de 1962 la reconstrucción del claustro de la emperatriz y de la parte alta de la torre.

En la actualidad la situación tutelar del Monasterio de San Jerónimo es la de un inmueble unitario constituido por dos monumentos, es decir:

- El Cuartel de San Jerónimo, que se correspondería con la zona monacal.

\footnotetext{
${ }^{24}$ Castillo Ruiz, J. [1997], p.396.
} 
- La Basílica de San Jerónimo, que se correspondería con la iglesia.

En cuanto la existencia de otros espacios que han estado vinculados desde siempre al monasterio, el compás, la plaza de naranjos, el espacio anexo al segundo claustro plantean ciertas dudas sobre si son parte del conjunto o no, ya que si se analizan las diferentes delimitaciones urbanas de la ciudad el resultado es muy contradictorio. La solución más acertada, como indica el profesor Castillo sería la redeclaración del Monasterio como único BIC, en la categoría de Monumento, la cual incluya todos los espacios anexos de valor histórico vinculados a él ${ }^{25}$.

Señalar también, que a través de la Resolución de 12 de febrero de 1993 la Dirección General de Bienes Culturales de la Consejería de Cultura y Medio Ambiente de la Junta de Andalucía, se produjo la incoación del expediente de delimitación del Conjunto Histórico de Granada, en cuyos límites quedan integrados tanto el Monasterio de San Jerónimo como por su espacio circundante delimitado dentro del entorno de este BIC realizado por la administración de cultura.

\section{Evolución histórica del entorno del Monasterio.}

La casa en la que se establecieron definitivamente los jerónimos, aunque desvinculada urbanísticamente de la ciudad musulmana intramuros, pertenecía a una tipología constructiva, cuyo fundamento formal y organizativo era conseguir la armonización entre la construcción y el espacio natural, lo que definía todo el contorno de la ciudad nazarí, como señala Torres Balbás, las casa de campo, almunias y alquerías, torres y palacios, medio ocultos entre huertos, jardines y arboledas, formaban una cintura... alrededor de las ciudades ${ }^{26}$.

La fundación del monasterio responderá a los modelos de ocupación y transformación llevados a cabo por los Reyes Católicos en la conquista de Granada, modelos que son comunes a todas las ciudades renacentistas, estos se basan en dos modos de intervención:

- La sustitución de los organismos arquitectónicos que funcional y representativamente definen la organización urbana musulmana por otros que representen el nuevo orden político y religioso, pero manteniendo la estructura urbana existente.

- La ubicación de forma aislada y extramuros de la ciudad de fundaciones de tipo asistencial o religioso que con el tiempo causaban una posterior extensión urbana, pero ya siguiendo un modelo formal nuevo.

\footnotetext{
${ }^{25}$ Castillo Ruiz, J. [1997], p. 399.

${ }^{26}$ Torres Balbás, L. [1982], p.303.
} 
Siguiendo este último modelo, durante el siglo XVI alrededor del Monasterio de San Jerónimo se creará un nuevo barrio, en él se ubicará la residencia de los Duques de Sessa, éste será eminentemente aristocrático...y que tenía por sus centros principales la calle Duquesa y la Placeta de los Lobos ${ }^{27}$.

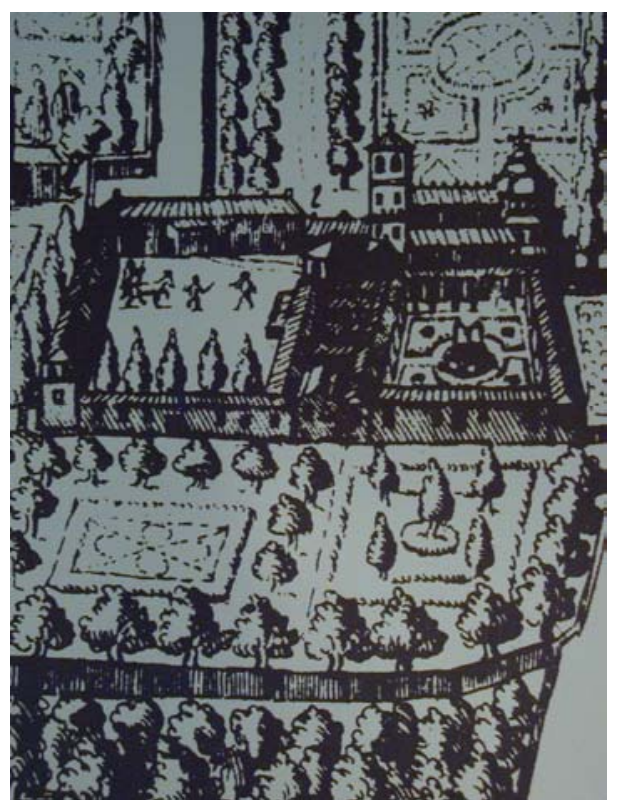

Plataforma de Vico, detalle del Monasterio

Con el tiempo y teniendo en cuenta el interés por la orden jerónima de integrarse en la ciudad, se va a ir consolidando una situación urbana que aún pervive hoy, se trata de la utilización del ábside de la iglesia como elemento definidor de la conexión urbana del monasterio, limitando la importancia del resto del convento y determinando de forma irreversible su participación en la configuración de la ciudad el área urbana comprendida entre éste y la Catedral, es decir, el barrio de la Duquesa y el de San Jerónimo.

Durante el siglo XVII el desarrollo y extensión de la ciudad va a propiciar la consolidación de esta área de la ciudad, se articulará de manera regularizada siguiendo los ejes de las calles Duquesa y San Jerónimo, ya creados en el XVI, aunque la urbanización de la calle San Jerónimo que se produce desde 1578 hasta 1688 y la ubicación en ella de importantes edificaciones y espacios públicos, así Colegiata de San Justo y Pastor, Convento y Plaza de la Encarnación, etc., conseguirá trasladar el centro de gravedad de esta zona desde Duquesa hasta San Jerónimo (calle) y San Juan de Dios.

Durante el siglo XVIII, al igual que el resto de la ciudad, la zona urbana ocupada por San Jerónimo apenas sufrió transformaciones importantes, a pesar de esto se pueden señalar algunos aspectos de la configuración urbana del entorno del monasterio que aparecen reflejados en el mapa topográfico de la ciudad de Francisco Dalmau del año 1796, así en él podemos ver la afirmación definitiva del barrio de la Duquesa como parte perfectamente integrada y articulada con la ciudad; la definición de los bordes urbanos que van a determinar, ya casi sin variaciones, la manzana que actualmente ocupa el Monasterio, éstos se conforman a través de cuatro vías que están perfectamente delimitadas aunque no del todo

\footnotetext{
${ }^{27}$ Bosque Maurel, J. [1988], p. 86.
} 
configuradas urbanísticamente, así se podrían identificar con las actuales Gran Capitán, Rector López Argüeta, Avenida de Fuentenueva y Melchor Almagro; y por último la transformación del espacio ajardinado perteneciente al Monasterio, situado en el ángulo formado por la iglesia y el compás, a través de edificaciones vinculadas a él como el Colegio de Latín y Música o el Seminario que fundó Díaz Sánchez Dávila en 1636.

En el siglo XIX, las intervenciones que se realizarán en la ciudad implantarán en ella modificaciones destinadas a satisfacer los objetivos de saneamiento, renovación, ornato, equipamiento, etc. De estas intervenciones, tan sólo la instalación de la estación del ferrocarril en las cercanías de San Jerónimo influirá en la configuración urbana del entorno del Monasterio. La implantación de esta estación demandará vías de comunicación más modernas y rápidas con el interior y con el sur de la ciudad. Tras el intento fallido de prolongar la calle Duquesa, el enlace de la ciudad con la estación se hará a través de la actual Avenida de la Constitución, como entrada, y de la calle San Juan de Dios como eje transversal necesario de comunicación este-oeste. La futura estructuración de estas vías, junto con la zona de Fuentenueva provocará un paulatino aislamiento urbanístico del monasterio de San Jerónimo.

En cuanto a las transformaciones urbanas del siglo XX, destacar la creación en las cercanías de esta zona del Campus Universitario de Fuentenueva, la creación de escuelas y facultades en la calle Rector López Argüeta, en palabras del profesor Castillo, la carencia de elementos que relacionen este campus con el espacio cercano del monasterio de San Jerónimo va a ser su más importante influencia sobre el entorno de este monumento ${ }^{28}$, según Revilla Uceda este campus, realizado en los años sesenta, se caracteriza por la incoherencia, espontaneidad e improvisación tanto de los distintos edificios construidos como de la urbanización del terreno, que se hace fragmentaria y anárquicamente, constituyendo una zona relativamente pequeña en un mosaico tosco de ambientes distintos $e$ incoherentes $^{29}$.

\section{Ubicación. Accesibilidad.}

Como ya hemos visto en el apartado anterior, el Real Monasterio de San Jerónimo se encuentra ubicado en el centro histórico de la ciudad, en el cruce de dos de los ejes más significativos, la calle de San Juan de Dios y la calle de San Jerónimo. El primero, pone en comunicación el Hospital Real, fundación de los Reyes Católicos y actual sede del Rectorado de la Universidad de Granada, con la plaza del Gran Capitán, en él nos encontramos con la Basílica de San Juan de Dios, donde se veneran sus reliquias, y el Hospital bajo la misma advocación, origen de la Orden Hospitalaria. El segundo, el de San Jerónimo, comunica la calle de Severo

\footnotetext{
${ }^{28}$ Castillo Ruiz, J. [1992], p. 406.

${ }^{29}$ Revilla Uceda, M. [1980], p.83.
} 
Ochoa, Rector López Argüeta, con la Catedral metropolitana, la iglesia del Perpetuo Socorro y la de San Justo y Pastor, antiguo asentamiento jesuita, con su colegio y primera Universidad, actual Facultad de Derecho.

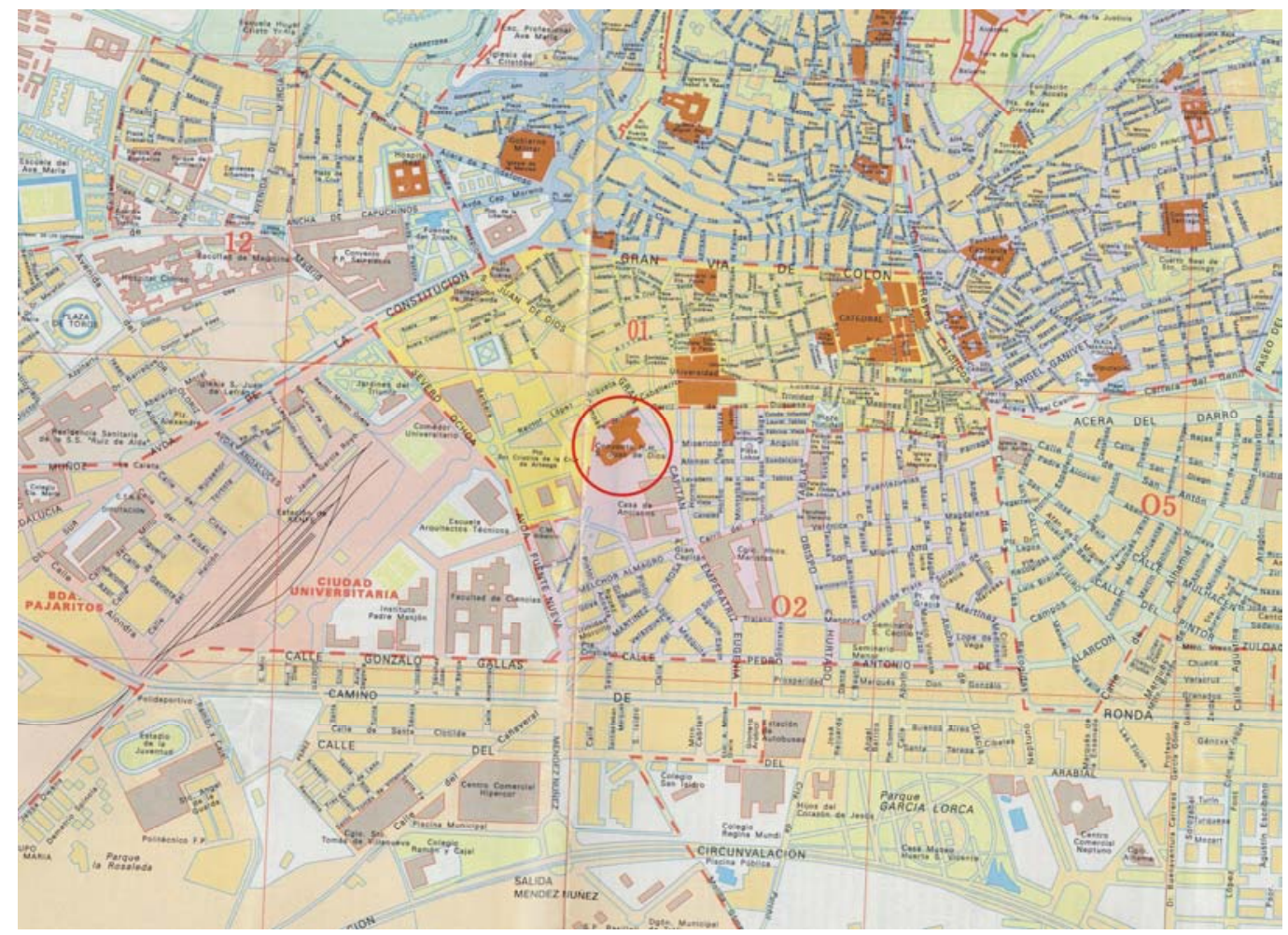

Plano actual de Granada.

Se encuentra, por tanto, ubicado en una de las zonas más céntricas de la ciudad, y más accesibles de llegar, de cualquier modo que el visitante elija, así:

- A pie, paseando se encuentra a tan sólo quince minutos de la Catedral y Capilla Real, dos de los lugares más visitados en la ciudad.

- En autobús urbano, la línea número 5 de los autobuses urbanos de Granada, tiene una parada en la calle Gran Capitán, a unos metros de la puerta del monasterio. Pero, casi la totalidad de líneas tiene una parada en la puerta del Instituto Padre Suárez, a X metros del monasterio, las líneas que pasan por este lugar son, 1, 3, 4, 5, 6, 7, 8, 9, 11, 33, C y F. En este mismo lugar, también tiene parada la línea especial de microbuses urbanos, el de la Alhambra y el del Albaycín y Sacromonte.

- En coche, se puede acceder por este medio hasta las dos puertas del Monasterio, a través de la Avenida de la Constitución, San Juan de 
Dios y Rector López Argüeta o Gran Capitán, según la entrada que se elija. Respecto a los aparcamientos, el más cercano se encuentra en la calle Gran Capitán, junto al Ambulatorio del mismo nombre, aunque éste tiene muy poca capacidad, por lo que se recomendarán el de la Avenida de la Constitución, frente a los Jardines de Triunfo, el de la plaza de Albert Stein y el de la Caleta.

- En autobús, en el caso de que los visitantes formen un grupo cuyo medio de transporte sea un autobús, éste puede dejarlos en la puerta de la calle Rector López Argüeta y recogerlos en el mismo lugar a una hora determinada. Mientras, los autobuses podrán ser aparcados frente a los Comedores Universitarios.

Además, de lo anterior, a unos pocos metros se localiza una parada de taxis, frente al Hospital de San Juan de Dios.

Desde el Monasterio se potenciará el que el visitante acuda bien caminando o bien en autobús urbano, esto último ya que el Monasterio es uno de los monumentos incluidos dentro del Bono Turístico de la ciudad, y éste incluye también un bono de diez viajes en este medio de transporte. Colaborando de este modo con los problemas de tráfico que se producen diariamente en el centro de la ciudad.

En el caso de que el visitante presente alguna minusvalía física, se permitirá el acceso del automóvil, desde la entrada de la calle Rector López Argüeta (la gran puerta de madera se abre sin problemas) hasta la misma entrada del Monasterio.

Pero no todo son ventajas, la ubicación del Monasterio tiene un inconveniente, ya que la calle Rector López Argüeta, está ocupada en su mayoría por edificios de la Universidad, así la Facultad de Ciencias Políticas, la Escuela de Trabajo Social, el Centro de Estudios de la Mujer, etcétera, además del edifico en ruina del Colegio de Latín y Música, y que son muy pocas las viviendas familiares en ésta calle, todo esto provoca que en horarios fuera de la actividad académica, así durante la noche, días festivos y períodos vacacionales, la calle permanece desierta, convirtiéndose en una de las más inseguras de la ciudad, en lo que también influye el terreno, sin edificar, que linda con uno de los muros del monasterio, utilizado como aparcamiento. Estas circunstancias habrá que tenerlas muy en cuenta a la hora de elaborar el plan de seguridad del conjunto monumental. Sin embargo, el tránsito de personas por la calle Gran Capitán es continuo a lo largo de todas las horas y de todos los días.

El Monasterio tiene dos accesos, uno por la calle Rector López Argüeta, y el otro, por la calle Gran Capitán. A través de los dos, se accede hasta el compás del Monasterio, una vez en él, el visitante se encuentra con dos entradas, una, la de la iglesia, su puerta principal y otra, la portada del Monasterio. 
Esta última será por la que todos los visitantes accedan al conjunto monumental, la puerta principal de la iglesia sólo se abrirá en el momento en el que se celebre algún culto, es decir, la celebración de la Misa los domingos y festivos a las 10 de la mañana, o en circunstancias especiales, tales como celebración de conciertos, etcétera. 


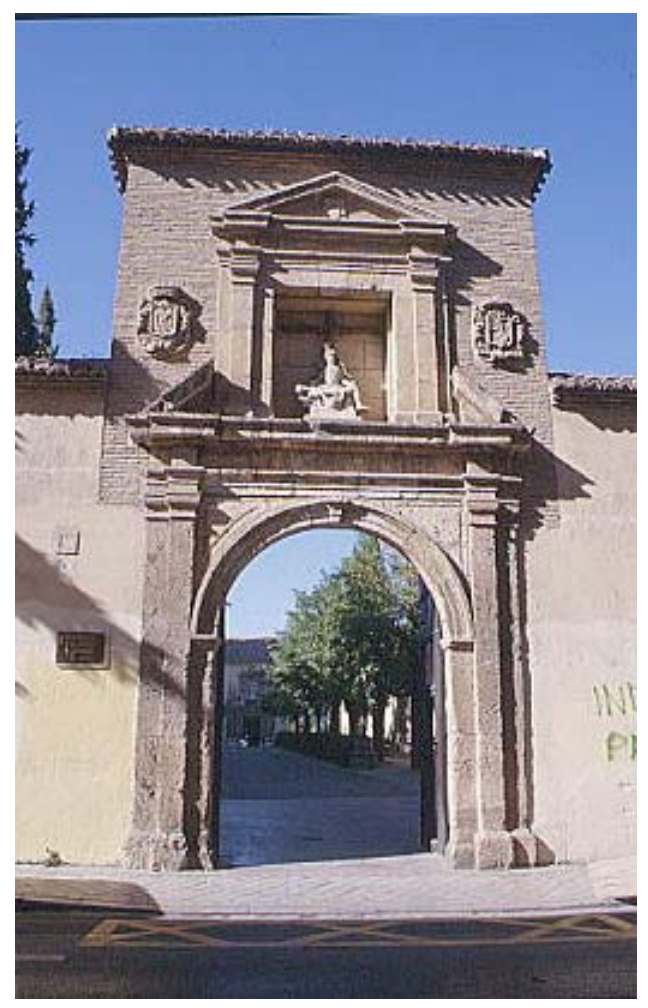

Acceso calle Rector López Argüeta.

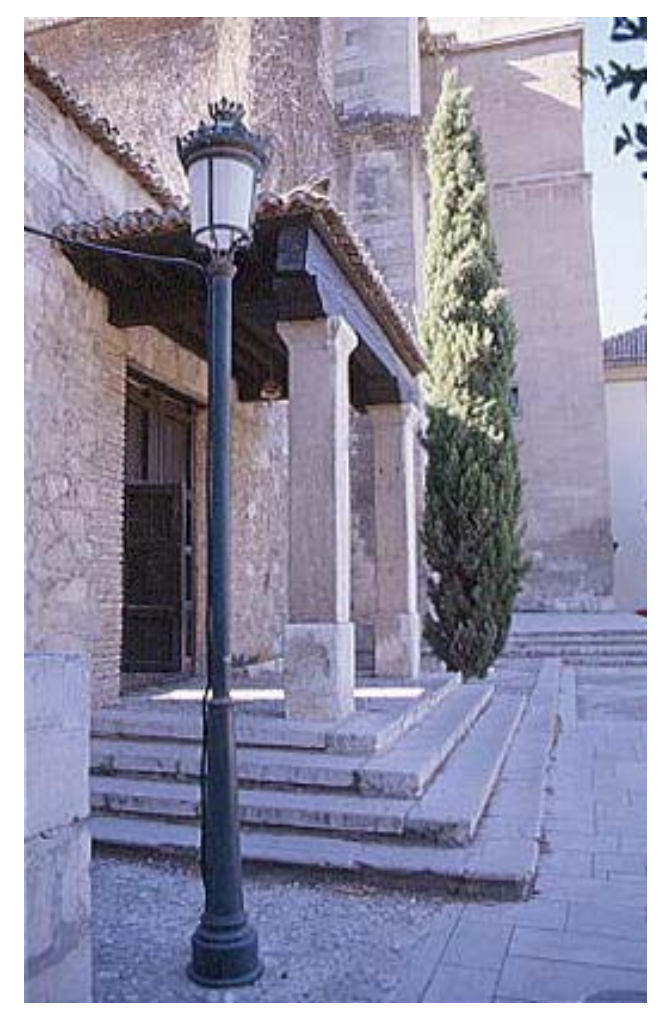

Acceso calle Gran Capitán

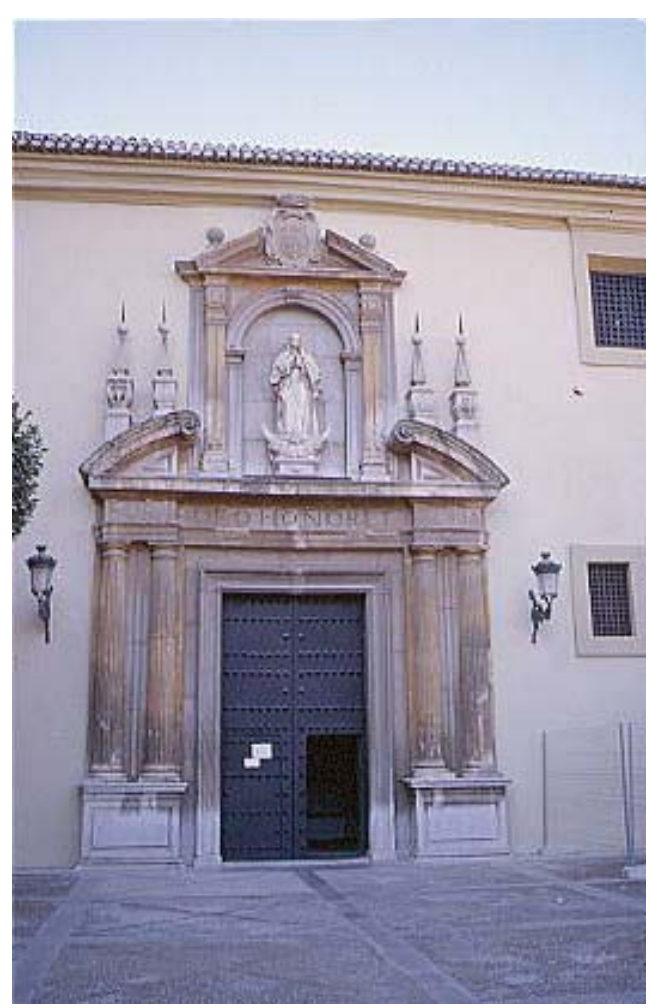

Acceso interior Monasterio. 


\section{Recorrido propuesto.}

La organización de los espacios en el recorrido global del Monasterio tendrá como patrón el propio trazado del edificio, trataremos de conseguir un recorrido fácil y accesible, que permita reconstruir la naturaleza y el espíritu del lugar, a la vez que lograr un itinerario que suponga una experiencia altamente satisfactoria para el visitante.

La circulación o movimiento de los visitantes, será desde el claustro a las salas, con la excepción del locutorio, espacio que supone un inconveniente en la organización espacial, ya que el visitante deberá volver sobre sus pasos para continuar su visita.

Se propondrá un recorrido a los visitantes, con un orden lógico, que ayudará a comprender el discurso que se pretende mostrar a través de la visita al Real Monasterio y Museo de San Jerónimo, pero si alguien no quiere seguirlo podrá optar por cualquier otro itinerario.

La entrada al monasterio se hará por la puerta de éste, ya que la de la iglesia permanecerá cerrada, tras esta puerta se entra a la zona del vestíbulo, en la que el visitante podrá adquirir la entrada. A continuación se llegará a la primera sala que servirá como introducción al conjunto monumental, actual portería del Monasterio, de aquí se accederá al locutorio y habrá que volver de nuevo a la primera sala para acceder al claustro.

Una vez en el claustro, podemos optar por dos tipos de recorrido:

Recorrido A: Portería- Locutorio- Claustro- Capilla de la Torre- ClaustroIglesia- Sacristía- Claustro- Sala de Capítulo de Culpas- Claustro- Sala CapitularClaustro- Sala de Profundis- Refectorio- Sala $2^{a}$ planta- Claustro- Portería- Zaguán.

Recorrido B: Portería- Locutorio-Claustro- $2^{\mathrm{a}}$ planta- ClaustroRefectorio- Sala de Profundis- Claustro- Sala Capitular- Claustro- Sala de Capítulo de Culpas- Claustro- Sacristía- Iglesia- Claustro- Capilla de la Torre- PorteríaZaguán.

La ventaja del recorrido A es el hecho de que se comprendería mejor la función original de algunas salas, así por ejemplo, desde la Sala de Profundis se podrá acceder al Refectorio, además lo último que se visitaría seria la sala de la segunda planta.

En cambio, las ventajas que presenta el recorrido B frente al A son: se vería primero la Sacristía y desde ella se accedería a la Iglesia, cómo realmente hacían los monjes y sobre todo, el final, ya que la visita culminaría de una manera espectacular: la iglesia.

Después de comprobar en el propio Monasterio el comportamiento y las preferencias de los visitantes, hemos optado por proponer el recorrido B. 
Pero vamos a comprender mejor el sentido de estos dos recorridos sobre los planos que adjuntamos.

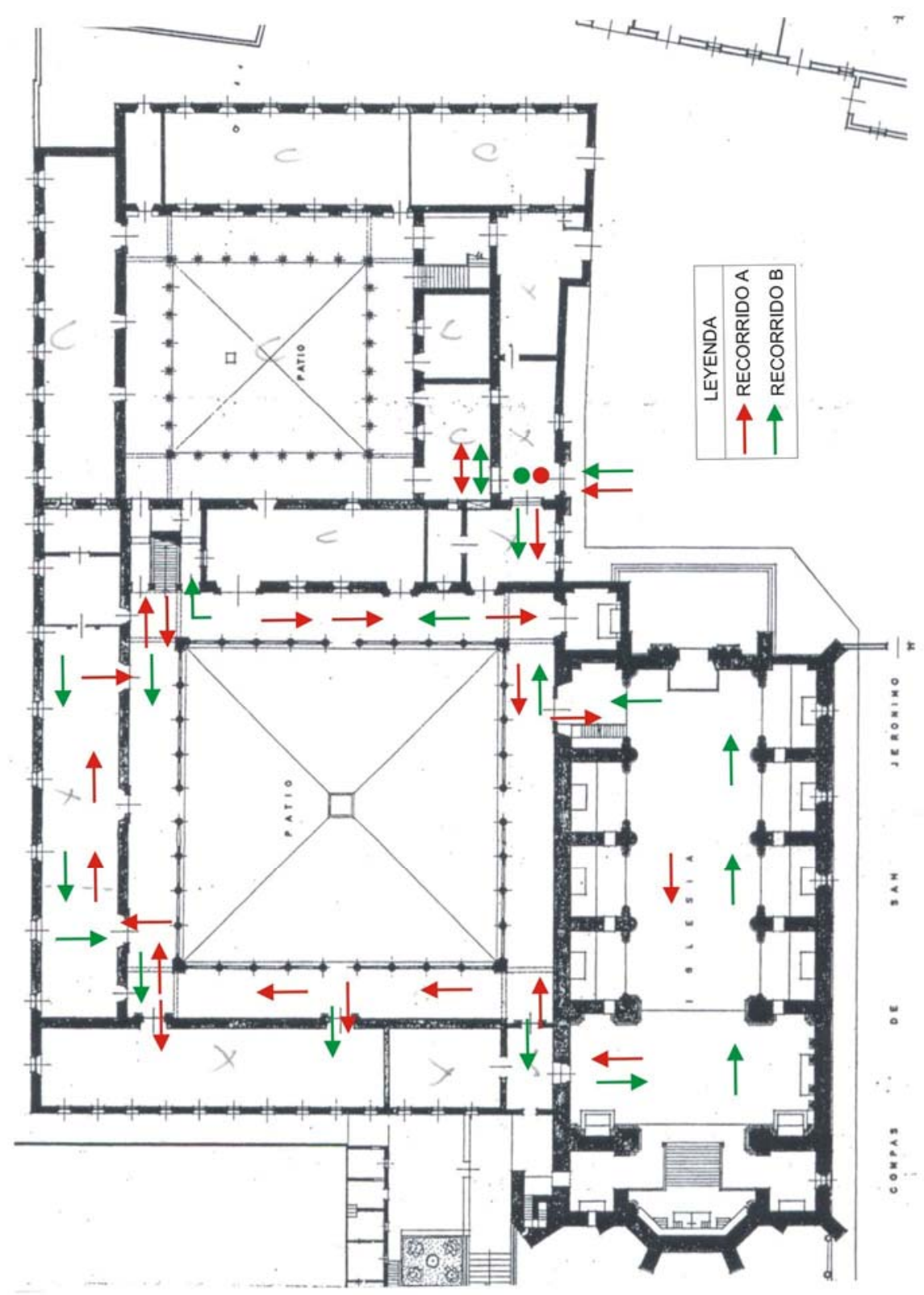

Planta Baja. 


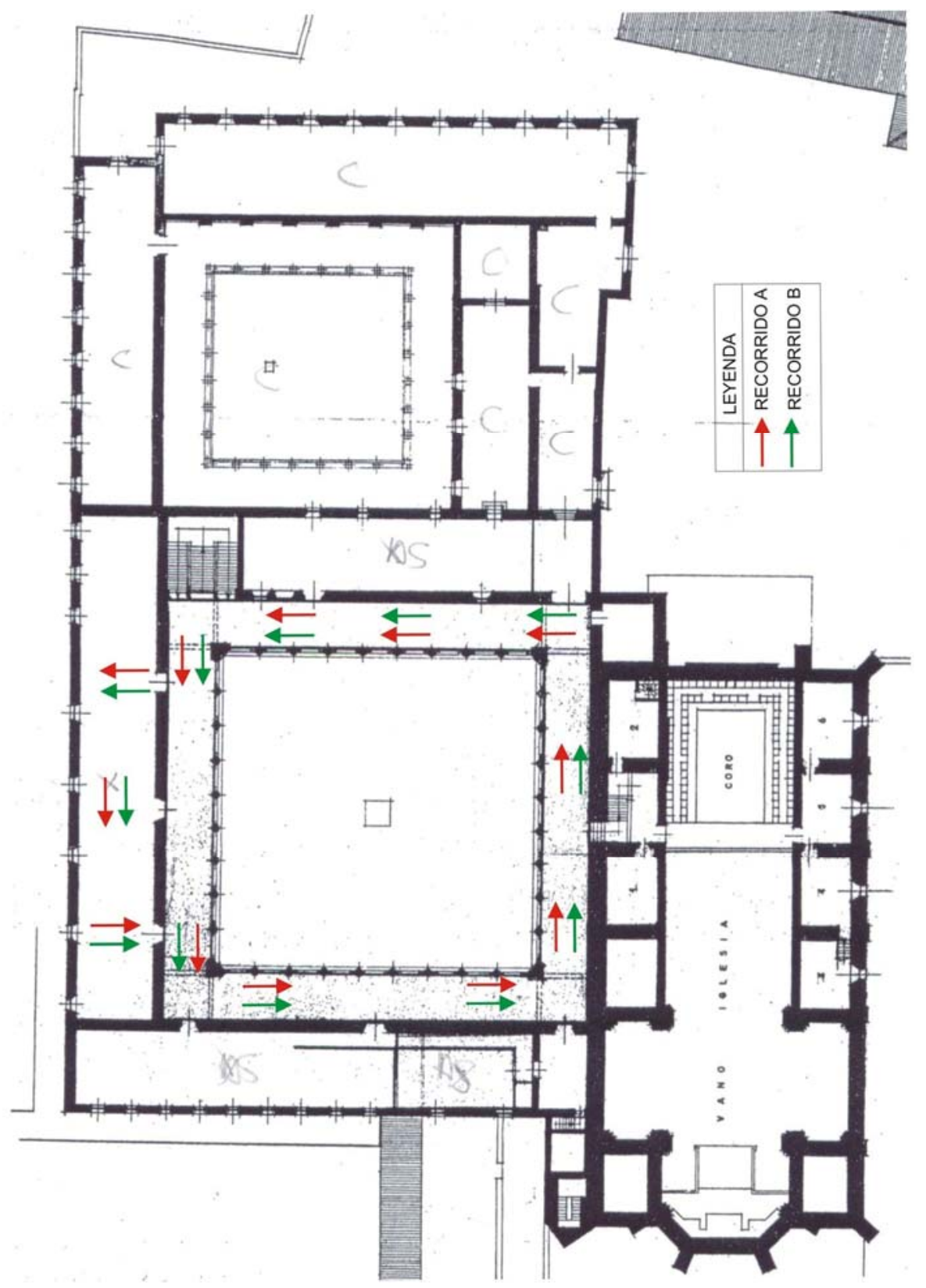

Planta alta. 


\section{Descripción de los espacios que se visitarán en el Monasterio.}

A continuación, describiremos las distintas dependencias que el público podrá contemplar durante su visita. También, explicaremos la función que desempeñaban estos espacios originalmente, ya que como hemos señalado con anterioridad éste, es uno de los temas o mensajes que pretendemos comunicar al visitante mediante nuestro discurso expositivo.

\subsection{Zaguán.}

Esta sala, el zaguán del Monasterio, es una sala rectangular, sin vanos. Es aquí donde vamos a situar la taquilla para la venta de entradas, la tienda en la que se venderán diversos objetos relacionados con nuestro edificio así como los productos que realizan las propias hermanas que residen en el Monasterio. En esta sala se ubicarán también los aseos.

\subsection{Portería.}

En los conventos o monasterios habitados por una comunidad femenina, el primer contacto se realizaba a través del torno, es decir, "un armazón giratorio compuesto de varios tableros verticales que concurren en un eje, y de un suelo y techo circulares, que se ajusta al hueco de la pared y sirve para pasar objetos de una parte a otra, sin que se vean las personas que los dan o reciben"30. Se localizaba en el vestíbulo del monasterio, al lado de la puerta de entrada al recinto conventual de clausura. Hoy, el torno no existe en el monasterio, ha sido sustituido por una puerta, con una ventana, por la que las personas atienden al visitante, pudiendo ser vistas.

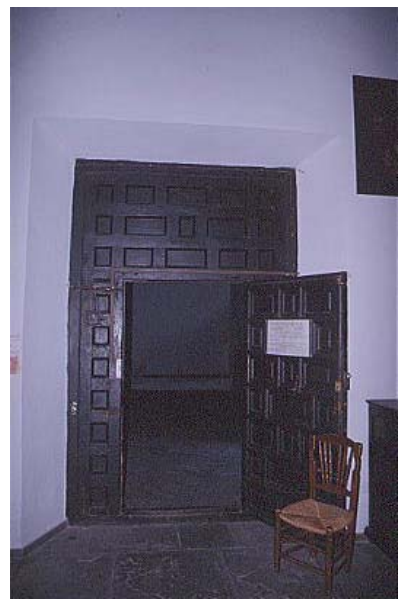

En la actualidad, es en este espacio, donde el visitante adquiere la entrada para poder visitar el monumento, también se han ubicado aquí dos armarios-vitrinas, en los que se muestran al visitante una serie de productos que están a la venta, algunos de los cuales han sido elaborados por la propia comunidad jerónima, así objetos religiosos como rosarios o libros, pañuelos y tapetes bordados por ellas, mermeladas de diversas frutas, o dulces.

Nosotros vamos a cambiar la función actual, ya que como hemos dicho anteriormente, situaremos el punto de venta de entradas, una tienda, etcétera en el zaguán.

En esta dependencia, nuestro primer espacio expositivo, donde intentaremos contar mediante paneles explicativos la historia del monacato, la de la

\footnotetext{
${ }^{30}$ Real Academia Española [1996], p. 1998
} 
Orden Jerónima y la del Monasterio, es decir, cuando y por qué surge y quienes residen en él.

También ubicaremos en esta sala un monitor, mediante el cual el visitante podrá acceder a otro tipo de información y a multitud de imágenes, la pantalla será táctil, muy fácil de usar.

En uno de los ángulos de la sala situaremos una mesa, con cuatro sillas, sobre ésta pondremos algunas de las publicaciones, convenientemente ancladas para evitar su hurto, que existen sobre el Monasterio, sobre la Orden, sobre la figura de San Jerónimo, etcétera, con el fin de que puedan ser consultados por el visitante que quiera, bien a la entrada o bien a la salida.

\subsection{Locutorio.}

Es ésta una dependencia que comparte la clausura con la zona de libre acceso de los visitantes, se divide en dos partes por medio de una reja, con marcados y afilados pinchos y una cortina en el interior; con dos entradas, una desde el interior del monasterio y otra desde el interior, abriéndose su ingreso para los visitantes en el zaguán.

Hay que señalar que esta dependencia no debió de existir en su origen, ya que sólo existe en los monasterios o conventos femeninos, con lo cual se realizó durante la restauración.

Existen dos locutorios, llamados el grande y el pequeño, uno a continuación del otro. El primero, es decir, el grande va a ser zona abierta al público general que visite el monasterio, mientras que el pequeño lo reservaremos como acceso restringido, sólo para los visitantes de las monjas.

Para acceder al locutorio, hay que bajar dos escalones, éstos pueden resultar una barrera arquitectónica para algunas personas, por lo que incorporaremos una pequeña rampa, con una barra fijada a la pared.

\subsection{Claustro Principal o Procesional.}

La primera portada, por la que accedemos al claustro es de orden dórico, labrada en 1593 por Martín de Navarrete. En el entablamento lleva el lema del monasterio: SOLI DEO HONOR ET GLORIA. Es esta una portada adintelada con medias columnas jónicas, guirnaldas, hornacina y profusa decoración.

El origen del claustro está en la transformación del impluvium de las casas romanas, convertido en el atrio de las primitivas basílicas romanas, constituyendo, después, el patio que centraba el conjunto de celdas, oratorio y dependencias de las primeras comunidades cristianas que surgen del aprovechamiento de villas romanas. 


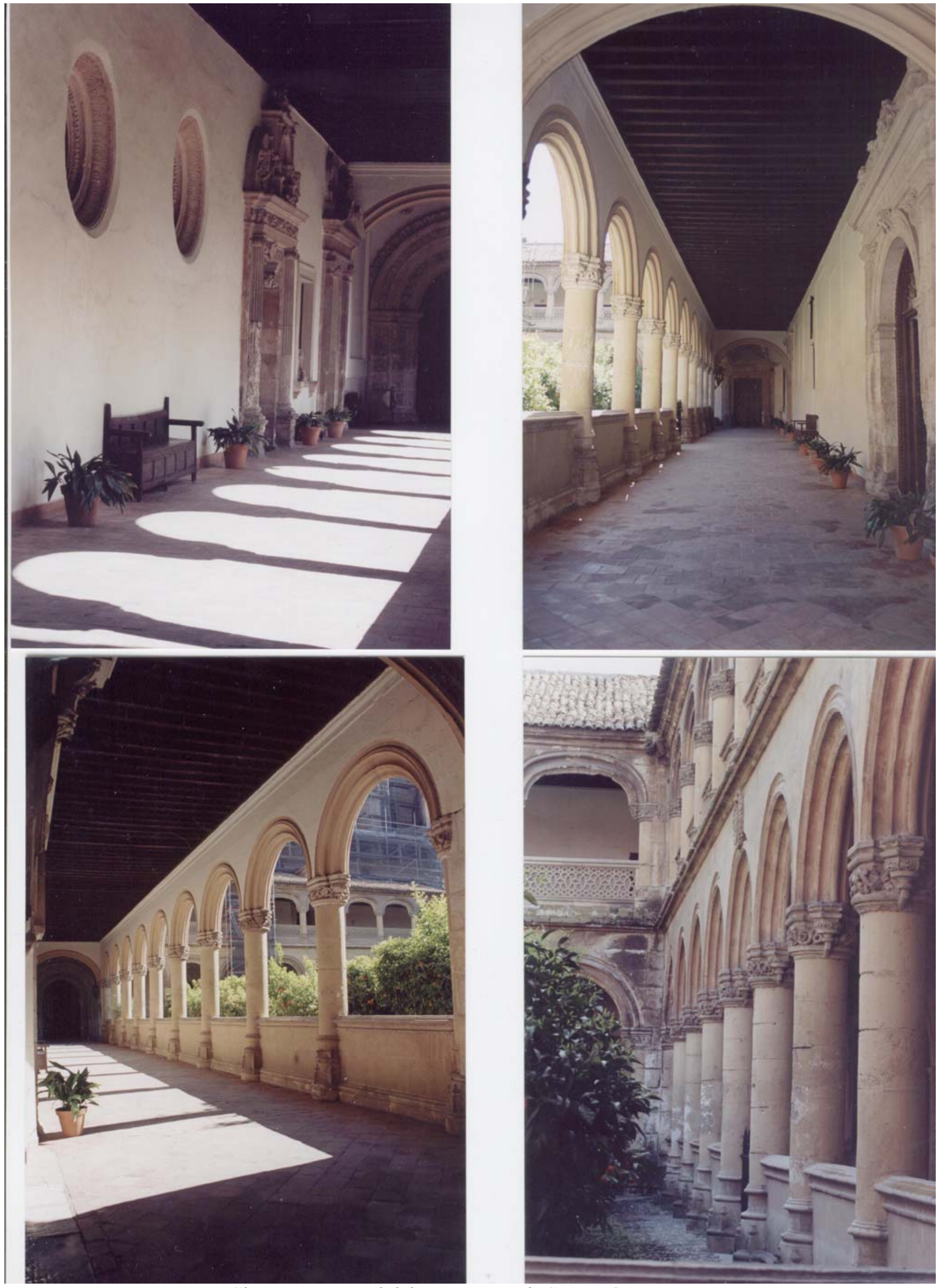

Claustro principal del Monasterio de San Jerónimo. 
El claustro constituye en los monasterios el centro de la vida cotidiana, a diferencia de la iglesia que lo es de la vida espiritual. Tiene acceso desde la portería y desde la iglesia.

La planta del claustro es cuadrada y cuenta con dos plantas. Las galerías se cubrían con vigas de madera y de acuerdo a la funcionalidad, en algunos lugares frente al clima, las galerías o vanos de las diferentes plantas del claustro se cerraban tras su construcción para evitar las inclemencias del tiempo, lo que no sucede en el de Granada.

En el centro del patio suele haber una fuente, pozo o cisterna. La fuente es el lavatorio, en algunos monasterios se cubría con un templete, para realizar allí las abluciones rituales.

Las funciones que se realizaban en este espacio eran muy variadas, ya que era el centro de la vida y muerte de los jerónimos.

Vida, porque alrededor de él se distribuyen todas las habitaciones de uso común, además sirve de espacio de recreo a la comunidad, ocupando el patio central un bello jardín, dividido en cuatro cuarteles y en medio la fuerote. Andrea Navagiero nos lo describía en el siglo XVI de esta manera: "el monasterio es bellísimo y pertenece a los jerónimos; tiene jardines, fuentes y dos claustros como no creo haberlos visto en ningún otro sitio. Los dos tienen fuentes en el medio, pero uno sobre todo es mucho más espacioso y magnífico y en el centro está repleto de bellísimos naranjos, de olorísimos cedros y enramados de mirtos, junto con otras delicadísimas plantas ${ }^{, 31}$.

Y muerte, porque el claustro servía como panteón de los miembros de la comunidad, bajo la solería de barro del claustro mayor están enterrados unos 500 monjes, nos lo recuerdan las losas de mármol que hay por todo el pavimento, éstas son mínimas lápidas en las que sólo aparece el nombre del monje y el año de su muerte, para ellos esto suponía un signo de humildad, ya que constantemente sus restos van a ser pisados.

Una de las lápidas presenta un tamaño mayor que las ya comentadas, se encuentra junto a la puerta de acceso y hace mención a la primera comunidad de monjes que habitaron el Monasterio en el año 1520. Además, el claustro también era centro de capillas y enterramientos para grandes familias de la ciudad. Los monjes, celebraban Misa diaria en todas las Capillas.

El claustro, es también el lugar donde la comunidad celebra sus procesiones, por ejemplo las jerónimas de Santa Paula en Sevilla llevan a cabo una en Semana Santa y a veces en otras solemnidades litúrgicas.

Desde el punto de vista arquitectónico el claustro, de planta cuadrada tiene dos cuerpos, el primero presenta nueve arcos de medio punto por ala, treinta y seis

\footnotetext{
${ }^{31}$ Navagero, A. [1951], p. 71-72.
} 
arcos que se apoyan en robustos fustes y capiteles de follaje con repisillas a los lados. En las enjutas de los arcos centrales podemos distinguir los escudos de los reyes fundadores y las armas del primer arzobispo de Granada, Fray Hernando de Talavera. El segundo cuerpo, en cambio, se configura con arcos escarzanos y una balaustrada calada de estilo gótico. Sobre el ala pegada a la iglesia, se encuentra el solarium o galería de convalecientes, de trece arcos semejantes a los del segundo cuerpo del claustro. En este piso es donde se encontraban las celdas y la biblioteca, es decir, la zona donde se desarrollaba la vida privada de los monjes.
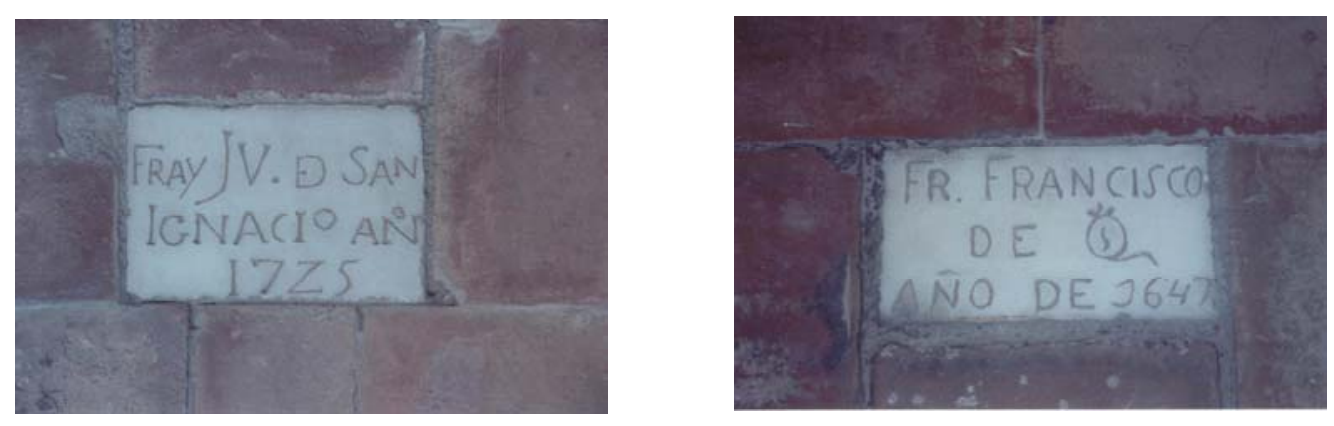

Todo el claustro estaría decorado con lienzos con representaciones de escenas diversas de la vida de San Jerónimo y de santos de la Orden, aún se pueden contemplar los huecos en los muros, en los que estaban situados. Nosotros vamos a ubicar en ellos unas reproducciones de obras sobre la vida de San Jerónimo y de otros personajes importantes de la Orden, como fray Hernando de Talavera o fray Ramiro de Alba, para que el visitante pueda contemplar mejor el significado del claustro.

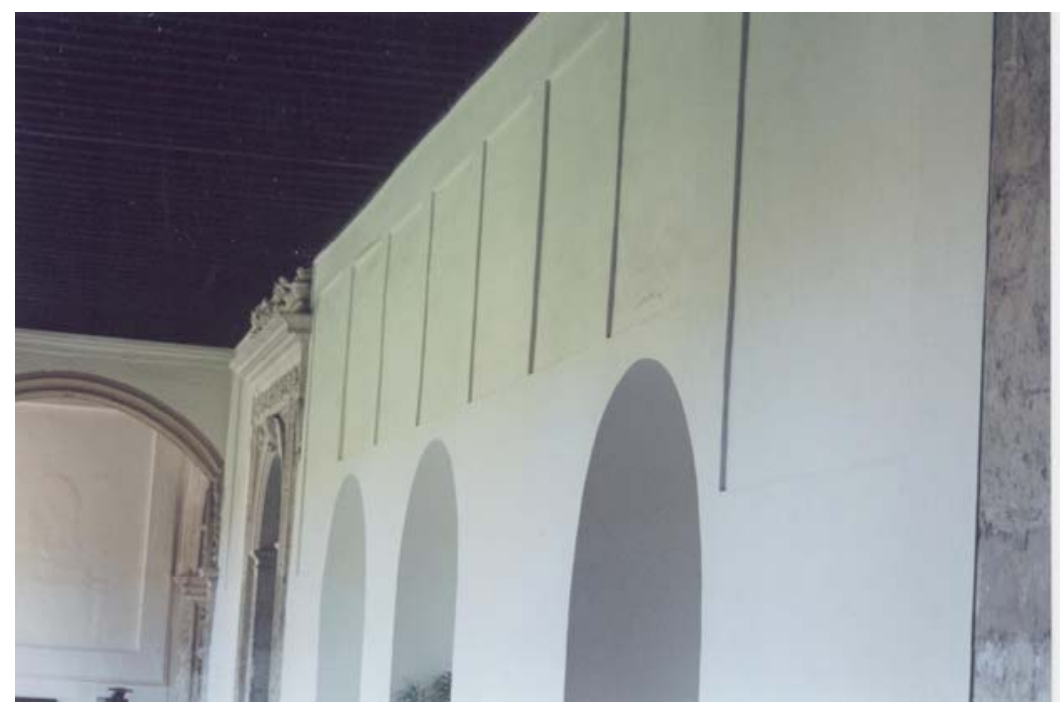

Claustro principal, Monasterio de San Jerónimo. 


\subsection{Capilla de los Díaz Sánchez-Davila.}

La segunda de las portadas del claustro daba acceso a la capilla de la familia Díaz Sánchez-Dávila y aunque la estructura original se ha perdido puede leerse en la cartela de esta estancia:

"Díaz Sánchez-Dávila/fundador de esta capilla/hi de sus memorias".

En la arquivolta, aparecen querubines y ángeles de un buen dibujo y traza, en las enjutas una cartela con bichas por crestería. Esta capilla ha sufrido muchas modificaciones, en la actualidad ha convertido en una capilla para la comunidad. Se ha cerrado el arco, de la segunda portada, con una gran plancha metálica con el fin de preservar la intimidad de las monjas que allí permanecen en oración.

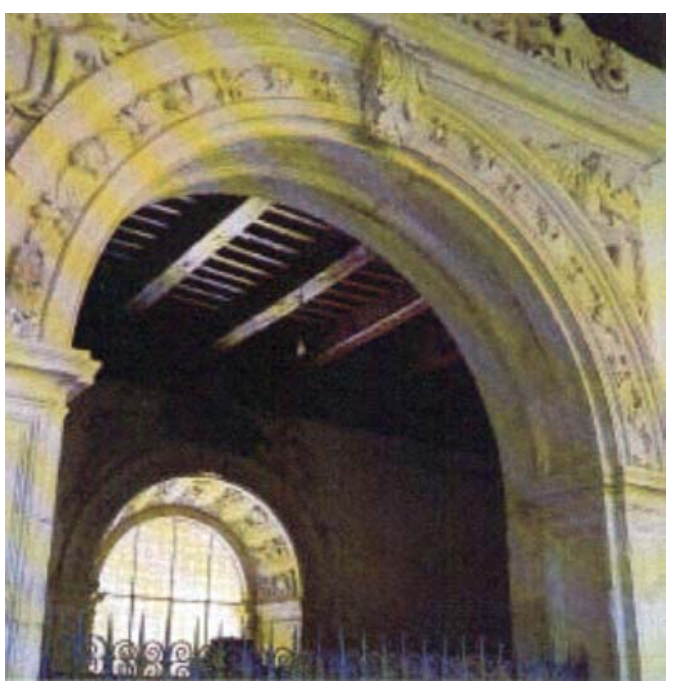

Portada Capilla de los Sánchez-Dávila.

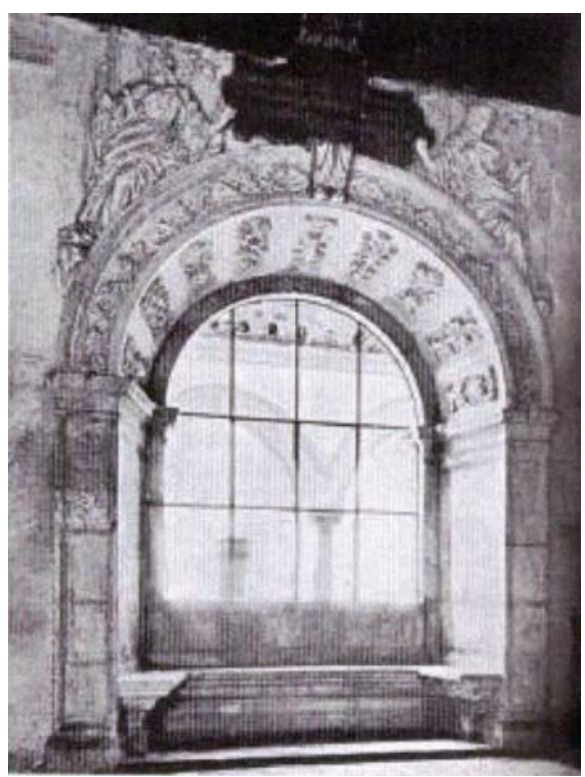

Arco interior de la Capilla.

Destaca en su interior un sepulcro, una de las piezas más bellas que se encuentran en San Jerónimo. Está situado en la pared, a los pies de la capilla, presenta ornamentación plateresca y en él aparecen representaciones de San Jerónimo con otro Santo, Santa Paula dando la regla a sus monjas y otros santos, y pintada sobre el mármol la figura yacente de un sacerdote, bajo el cual corre la siguiente inscripción:

"Este enterramiento de esta parte es del muy reverendo señor licenciado don Gerónimo de Madrid, Abbad de Sancta Fée, dignidad en la Sancta iglesia de Granda, uno de los dos fundadores que primero començo a edificar este monesterio y dexó Renta para dotes de veinte monjas pobres que de su parte sean rescebidas sin dote en esta casa perpetuamente. Falleció en XXII de março de MDXXXIII años. Y es del patrón que agora es al presente y fuere de la parte 
del dicho señor Abbad, ya difunto, por él nombrado, que pueden meter número de diez y ocho monjas pobres sin dote arriba escritas y las vacantes desde dicho número. Acabose de labrar este Monasterio en el año de MDXL, poblóse de monjas en XXIII días del mes de Mayo de MDXLIII años".

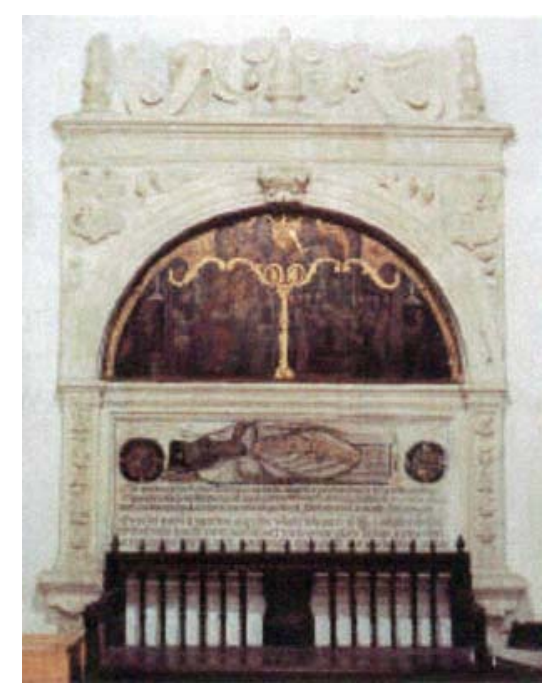

Sepulcro de fray Jerónimo de Madrid.

Evidentemente, este sepulcro no pertenece a este Monasterio, sino que se trasladó desde Santa Paula, donde ocupaba un lugar preferente en su iglesia, cuando las monjas jerónimas se instalan en el Monasterio de San Jerónimo.

En el interior de esta capilla, ha quedado una de las portadas, obra de Siloé, quizá la más bella, presenta un arco abocinado cubierto de grutescos y, sobre él, dos figuras de Virtudes con magníficos estudios de ropajes tras los que se acusan las formas del cuerpo.

Todo el mobiliario de la capilla es nuevo, adaptándose a las necesidades de la comunidad.

\subsection{Claustro menor.}

Desde el claustro principal se puede contemplar el segundo claustro construido hacia el año 1520, en él nos encontramos elementos renacentistas y góticos con otros de tradición musulmana. En el primer cuerpo aparecen siete arcos en cada uno de los lados, apoyados en columnas con basas, capiteles y una especia de cimacios de inspiración árabe.

El segundo cuerpo presentaba arcos escarzanos y molduras góticas. En el centro del patio se encuentra un pozo. Este claustro sufrió mucho en el incendio del año 1927, el segundo cuerpo se perdió por completo, por lo que tuvo que ser prácticamente rehecho. 
Se conoce también a este claustro como el de la Emperatriz, ya que fue en esta parte del Monasterio donde la emperatriz Isabel, esposa de Carlos V, residió durante su estancia en la ciudad de Granada, del 28 de mayo al 7 de diciembre de 1526. Mientras que el Emperador estableció su residencia en la Alhambra.

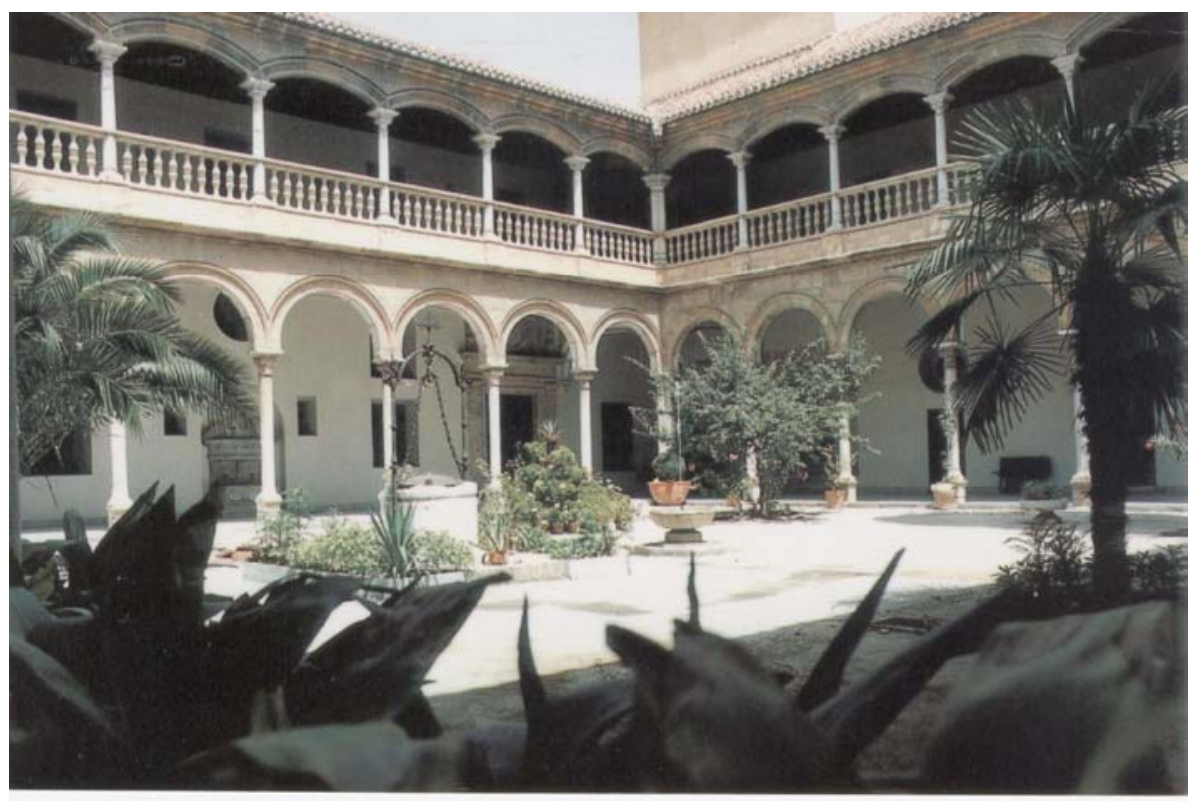

Claustro pequeño Monasterio de San Jerónimo.

Cuando el Monasterio era ocupado por los jerónimos este claustro servía de hospedería pues ésta era una de las obligaciones de la Orden. Este segundo claustro surgió para evitar que los fieles que solicitaban la hospitalidad de los monjes perturbaran el silencio y recogimiento del claustro principal.

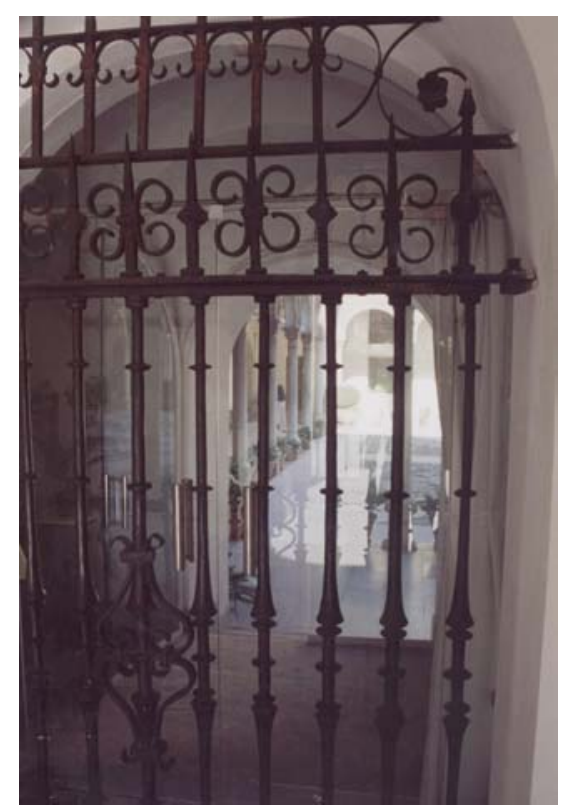

A este claustro, el visitante no podrá acceder, ya que se encuentra dentro de la zona de clausura, pero se puede contemplar muy bien desde el otro claustro, ya que se ve a través de esta reja. 


\subsection{La Escalera.}

Contigua a esta capilla está la magnifica escalera monumental por la que se accede a la segunda planta. Construida con piedra de Sierra Elvira desemboca en el corredor alto del primer claustro a través de una pequeña portada de estilo plateresco realizada en yeso.

La bóveda, fue destruida por el incendio del año 1927, reconstruyéndose fielmente su decoración de yeserías del siglo XVIII.
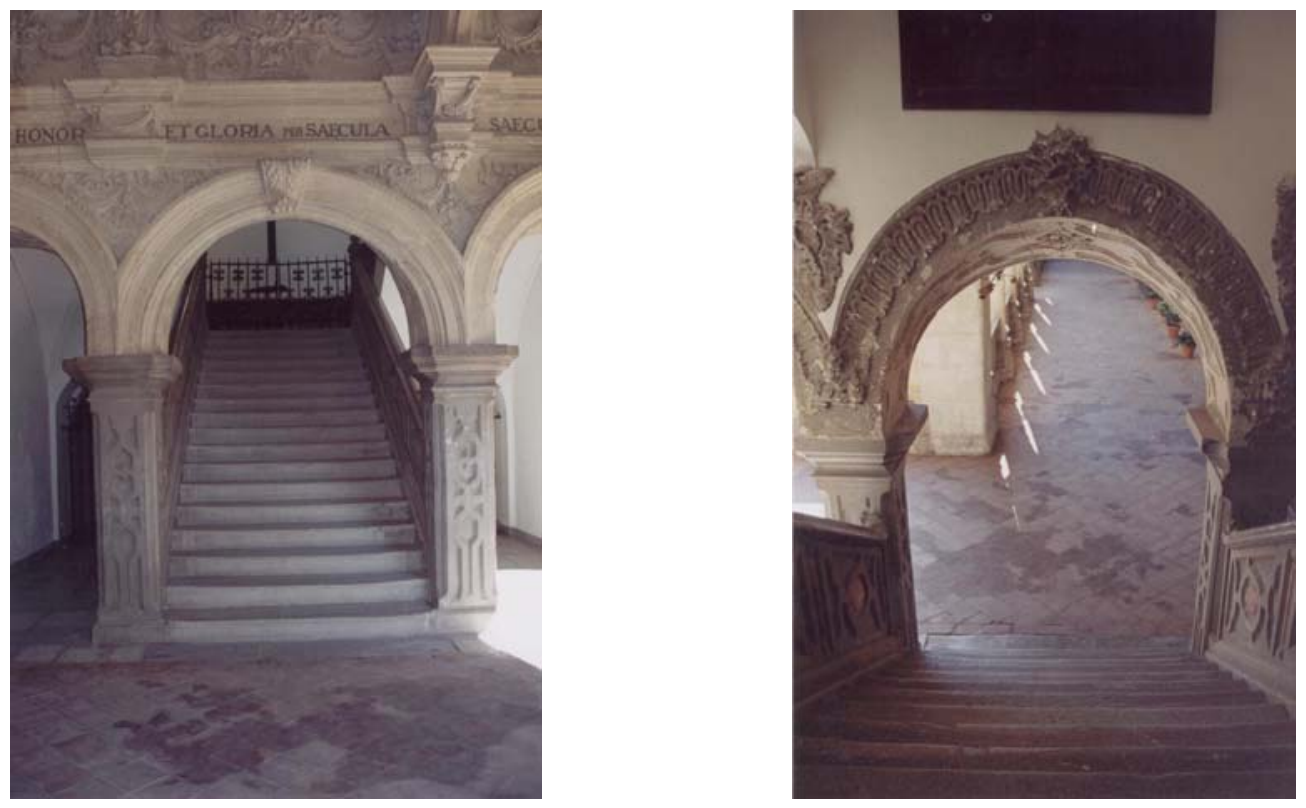

Escalera del claustro principal del Monasterio de San Jerónimo.

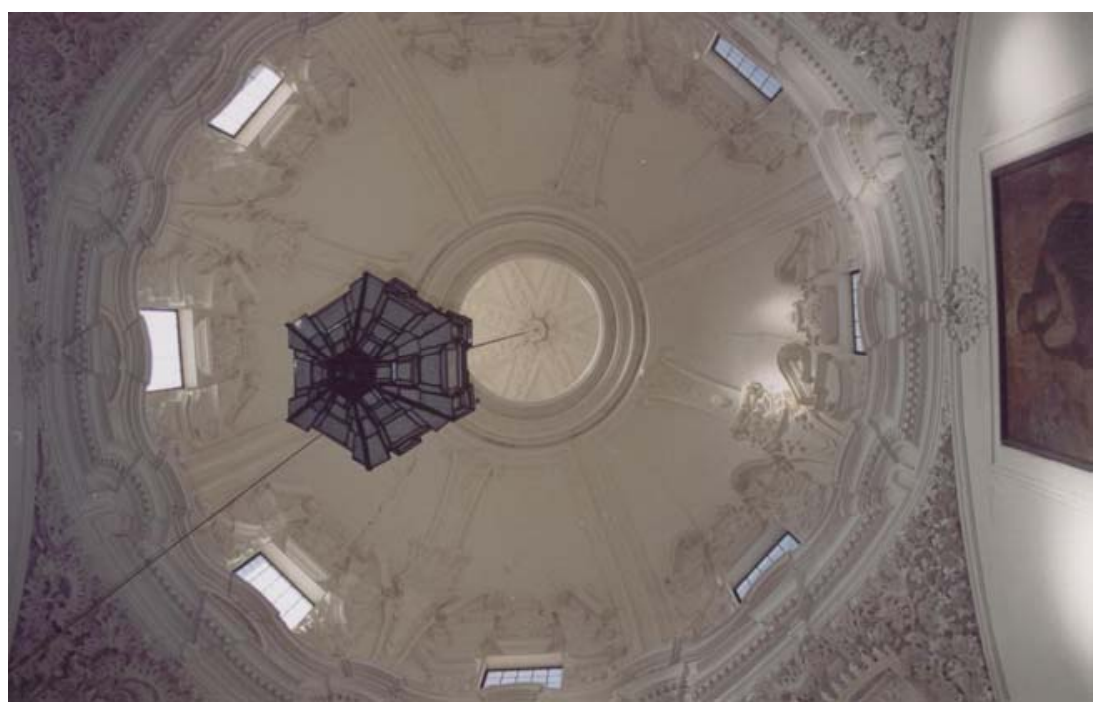

Bóveda de la escalera. Monasterio de San Jerónimo. 


\subsection{La Torre.}

La explicamos aquí, porque dentro del Monasterio, éste es el mejor lugar para que el visitante pueda contemplarla, (en el ángulo de la escalera, junto a la puerta del Refectorio).

A los pies de la iglesia, a la derecha de su entrada, se encuentra la torre, obra de Siloé, se acabó en el año 1565 después de su muerte. Tenía ocho arcos para campanas, y su sonido era tal que como afirmaba Colina Munguía "este campanaje era de las mejoras músicas desta ciudad, que muchas Catedrales no tienen tal",32. La torre estaba rematada por un antepecho y un chapitel muy elevado.

Cuando las tropas francesas ocuparon el Monasterio demolieron el cuerpo superior de la torre, construyendo con la piedra el puente Verde, sobre el río Genil, conocido también como puente de los franceses. Como este puente se encuentra en una zona alejada del Monasterio, al final del Paseo de la Bomba, en la cartela explicativa de la torre, incluiremos una fotografía del puente junto con un detalle del grabado de Heylan.

De la torre nos quedan algunos documentos gráficos así se puede ver en la Plataforma de Granada de Ambrosio de Vico, en un grabado de Hielan o en la acuarela de Cosme de Medicis de $1669^{33}$. La restauración se realizó con un dibujo que había publicado Gómez Moreno en su Guía de Granada.

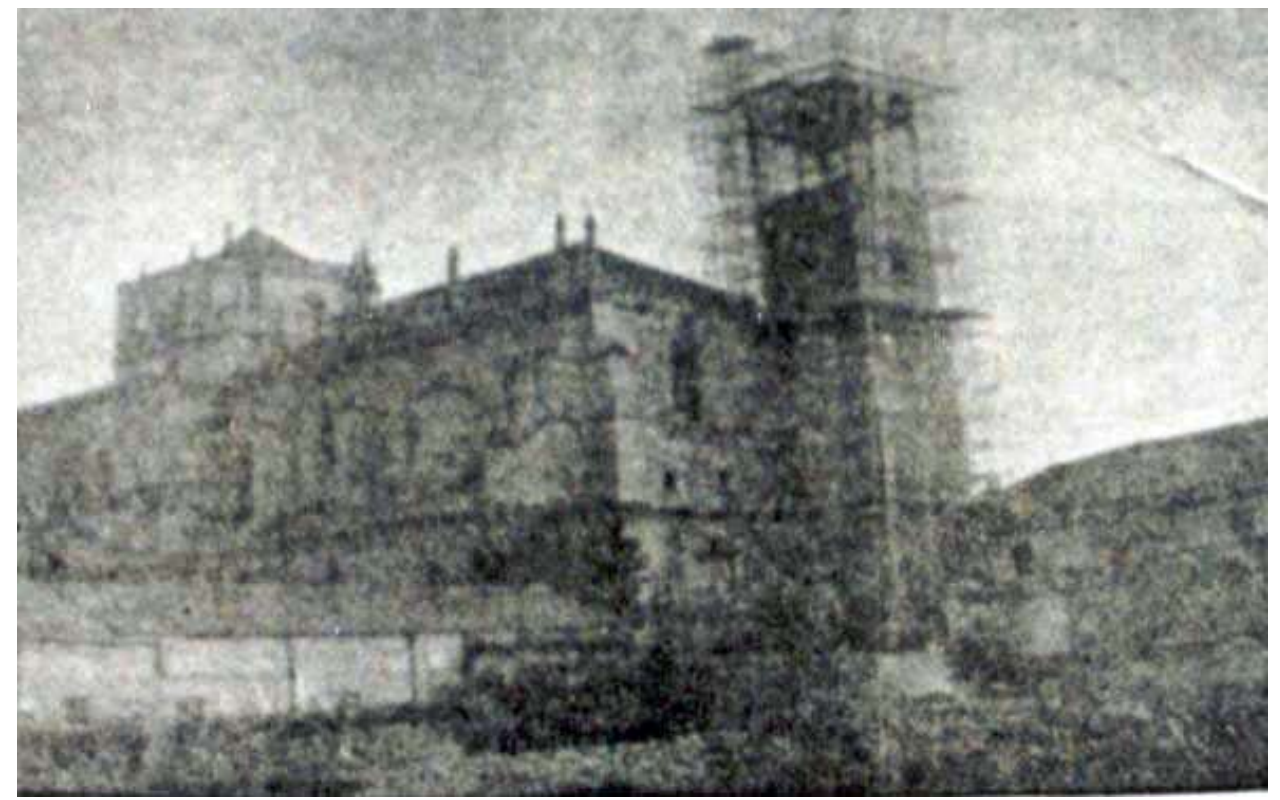

Momento de construcción de la torre. Diario Patria, 13 de noviembre de 1964.

\footnotetext{
${ }^{32}$ Colina Munguía, S. [1964], p. XX

${ }^{33}$ Estas imágenes se encuentran recogidas en el Apéndice de este Proyecto.
} 


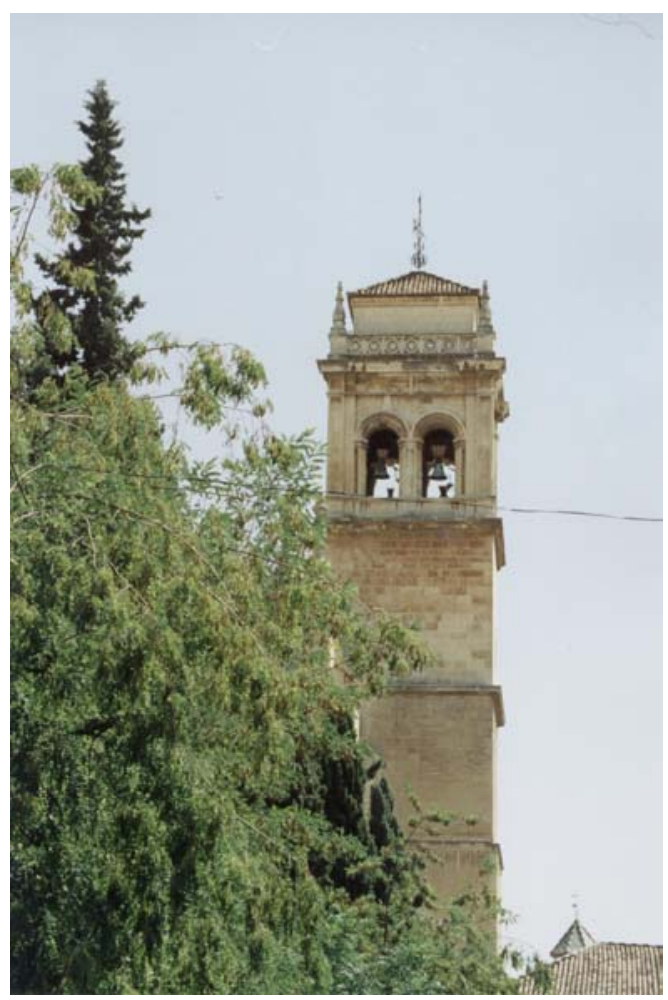

La Torre del Monasterio de San Jerónimo en la actualidad.

Ésta se divide en dos cuerpos lisos, con remate de moldura a nivel del cornisamiento general. La parte rehecha arranca con otro piso acabado en cornisa y encima del cuerpo de las campanas que tienen pilastras adosadas a los flancos, y en los centros dos huecos para campanas en cada uno de los cuatro costados, archivoltas molduradas y ancha cornisa. Sobre ésta pináculos y balaustrada de piedra calada a la manera del remate del cimborrio de la iglesia de la que la torre forma parte. Termina con un cuerpo más estrecho rematado por tejado con cruz.

El duque del Infantado donó, en el año 1966, una campana del siglo XVIII para la torre.

\subsection{Refectorio-Cocina.}

Era ésta una de las dependencias principales del claustro, en la que se reunían los miembros de la comunidad para comer. Solían presentar una sobria decoración, algunos lienzos alusivos a los mandamientos u obras de caridad eran los que la decoraban, siempre estaba presidido el refectorio por un Crucifijo o una representación de la última Cena.

Refectorio del Monasterio de San Jerónimo.

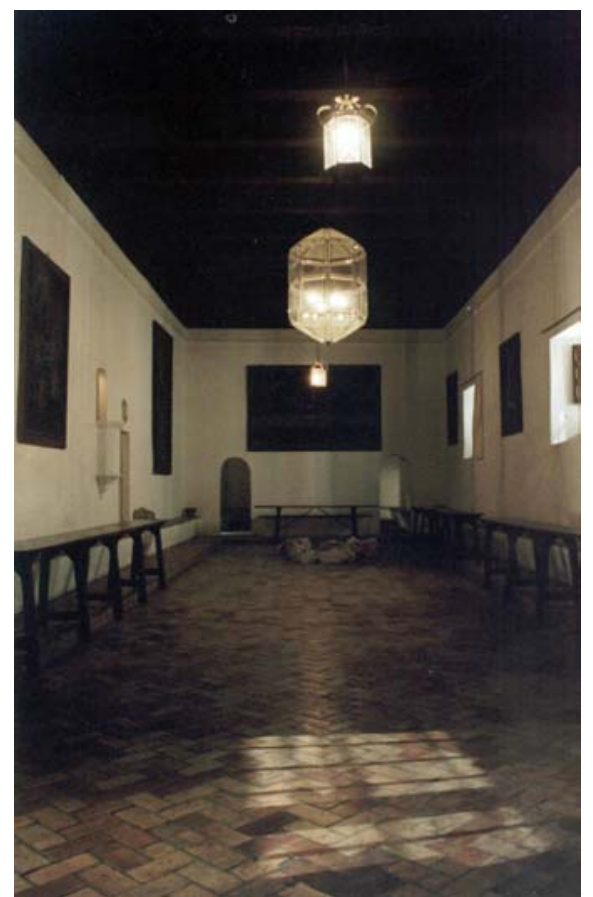


En los muros, adosados, están los asientos, un banco corrido de fábrica, aunque en algunos era de madera. Las mesas, de madera, son exentas y pequeñas, se ocupaban sólo por un lado, el de los muros, para facilitar, por la parte exterior, el que se pueda servir.

Hay una mesa presidencial en el testero, para ser ocupada por el prior del monasterio, aunque esta presidencia se solía ceder cuando llegaba un visitante que tuviese mayor autoridad o jurisdicción.

En algunos monasterios se observaba un orden en la disposición de los comensales. Así en las mesas inmediatas a la presidencia se sentaban los padres, después, los religiosos escolares (llamados de coro en algunas órdenes), luego los novicios y, finalmente los hermanos legos. Esta estancia se reservaba sólo para la comunidad, por lo que no era habitual la presencia de personas extrañas, aunque se hacía la excepción en los casos de la que la visita fuese de prelados, religiosos de otras órdenes o seglares de pública devoción.

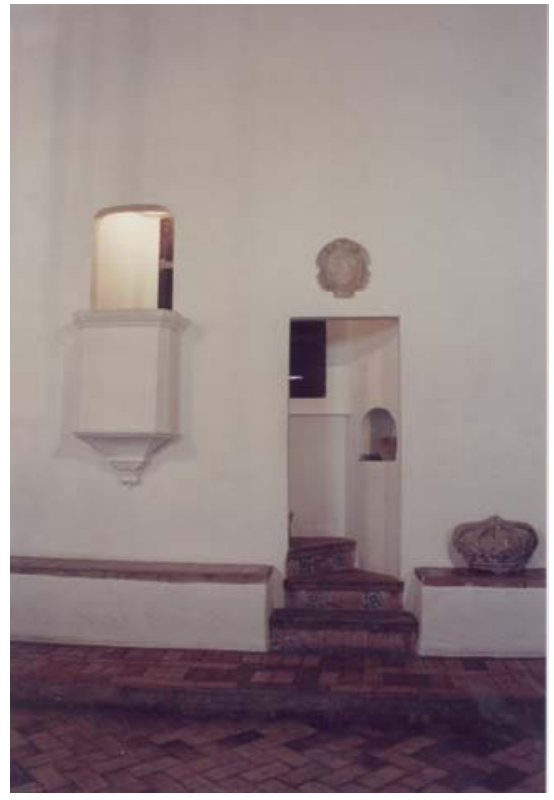

Púlpito del Refectorio.

El silencio en este lugar es riguroso. Para mantenerlo y durante la comunidad, desde el púlpito, que se encuentra en el lateral de uno de los muros, uno de los religiosos lee un capítulo de las Sagradas Escrituras, un libro de contenido espiritual o materia edificante e incluso, en algunas comunidades se leían las Constituciones o las Reglas de la Orden. El padre Sigüenza nos lo relata, "los que huvieren asistido algunas vezes a las comidas de la religión de san Jerónimo, podrán decirlo, y lo avran provado, que no es menos lugar de oración el refetorio, que el choro: tanta la compostura, la mortificación, silencio, y actos de devoción: ayudado, y despertado todo esto con la lecion santa, que se escucha con grande atención ",34.

La comida se disponía en fuentes o soperas para que ellos se sirvieran, pero en las órdenes mendicantes, así los franciscanos o los dominicos, ésta se servía ya dividida en raciones individuales.

El refectorio también sirvió para actos de humildad, así ocurría en el tiempo de cuaresma, cuando los miembros de la comunidad acudían a este lugar antes de la cena para la disciplina pública. Una vez que se bendecía la mesa, se

\footnotetext{
${ }^{34}$ Sigüenza. I., documento citado por Ruiz Hernando, J.A [1997], p. 56.
} 
apagaban las luces y los monjes se azotaban hasta que sonaba la campanilla del prior.

En cuanto a la cocina, ocupa el lugar al lado del refectorio, comunicándose con éste por medio de una gran ventana. Las cocinas de los monasterios, solían ser de grandes dimensiones, aunque esto dependía del tamaño del monasterio así como de la cantidad de miembros de lo habitaba. Generalmente, tenían fuego con una chimenea externa y contaban con grandes dependencias, almacenes, despensas, etc. Contaban con agua corriente, normalmente y a veces tenían vinculadas otras dependencias, así de bodega.

\subsection{Sala de Profundis.}

Se encuentra situada junto al refectorio. Recibe este nombre porque los monjes se reunían allí antes de ir a tomar la refección (alimento moderado para reparar fuerzas), rezando el salmo que empieza con esas palabras en recuerdo de los benefactores difuntos.
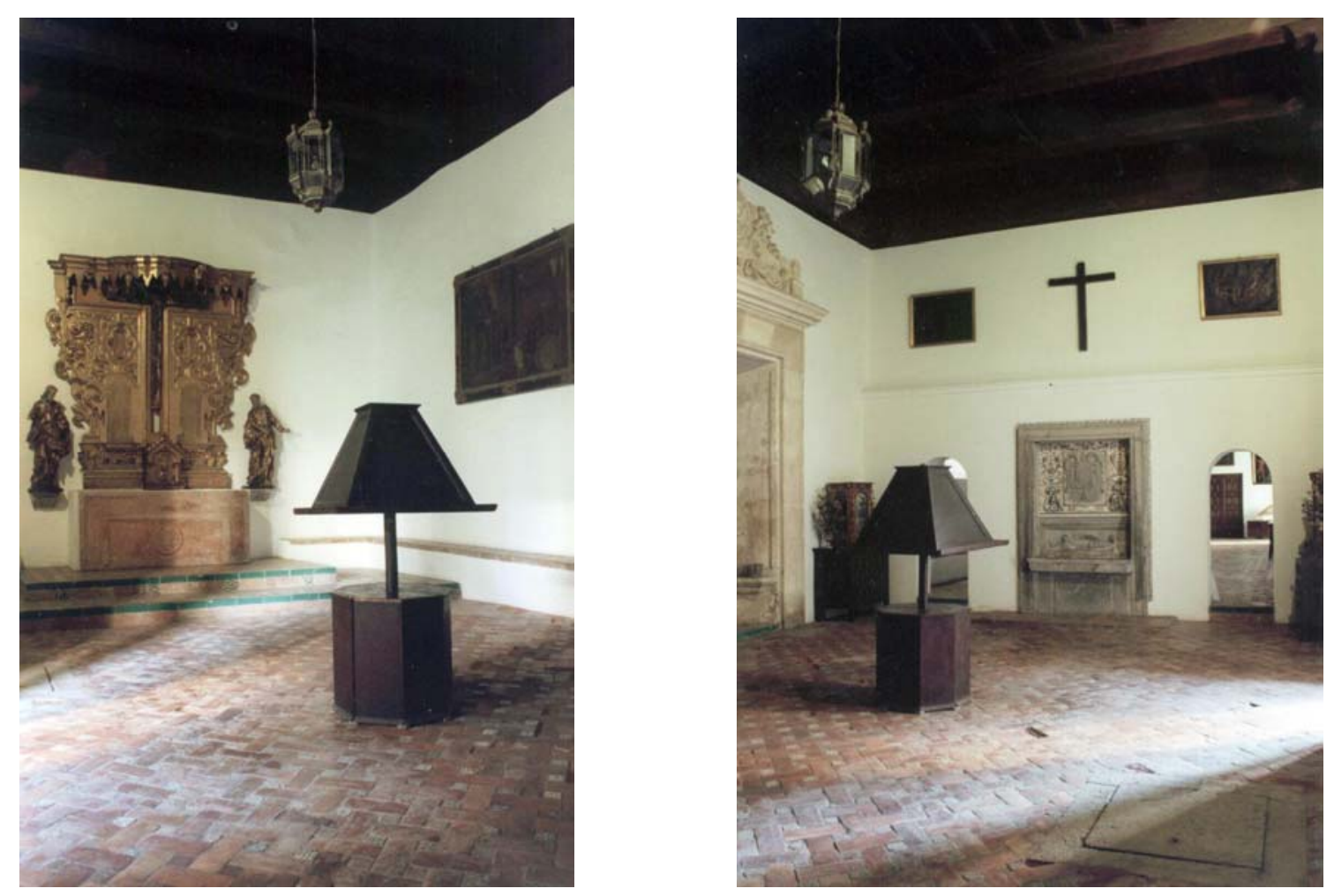

Sala de Profundis. Monasterio de San Jerónimo. 
Entre la sala De Profundis y el claustro, en los monasterios medievales, se instalaba una fuentecilla o lavabo que además de cumplir una función religiosa servía como medida higiénica antes de la comida, evitando así el que los monjes se trasladasen a las celdas para lavarse. Paulatinamente este lavabo cambió de lugar, aunque conservando su proximidad al refectorio, en algunos lugares se situó en el centro del claustro. En nuestro caso, la fuente. De piedra, se encuentra adosada a la pared, entre los dos arcos por los que los monjes accedían en sendas filas hasta el refectorio.

\subsection{Capilla.}

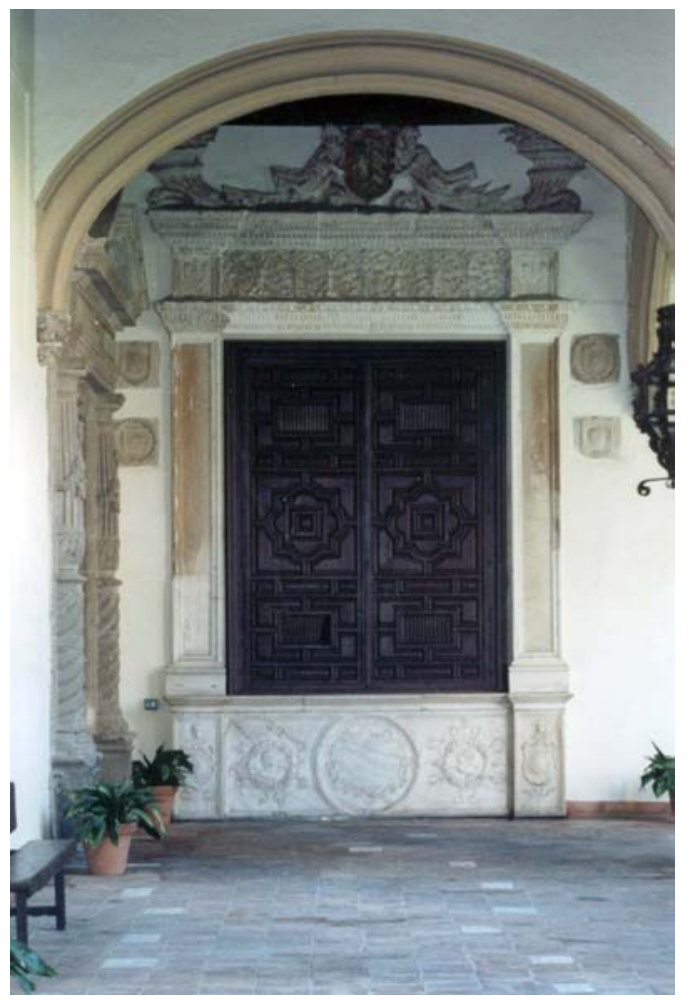

Al final de este ala del claustro, nos encontramos con un bello frontal italiano de mármol blanco. Para algunos autores éste es el lugar en el que se encontraba el Entierro de Cristo, realizado por Jacobo Florentino, que actualmente se encuentra en el Museo de Bellas Artes de Granada. La pared se encuentra bellamente decorada con pinturas murales.

Frontal italiano, claustro principal

Monasterio de San Jerónimo.

\subsection{Sala Capitular.}

La portada por la que se accede desde el claustro a la Sala Capitular, es de estilo herreriano. 
Es el lugar de reunión de la comunidad, deliberándose allí todo tipo de temas, tanto de gobierno, así elección de cargos, como para dictar castigos, plantear temas económicos, dar a conocer disposiciones de la casa general o papeles, etc.

$\mathrm{Su}$ nombre viene de Capitulum y en un principio, estas reuniones se llevaban a cabo en una de las galerías del claustro, siendo a partir del siglo $\mathrm{X}$ cuando comienzan a aparecer las salas capitulares, que se construyen en el lado oriental del claustro con el que tenían comunicación.

Suele tener planta cuadrada o rectangular, una puerta central y dos ventanas laterales. Su mobiliario cuenta con una sillería que se adosa a los muros, en una o dos alturas según el número de religiosos. Aunque más sencilla que la coral, destaca el sitial presidencial para el prior.

La sala capitular suele servir de sepultura para abades y priores, aunque en algunos casos se entierran también nobles y fundadores. En el centro de la sala capitular estaba siempre, sobre un atril, el libre de la regla de la comunidad. Su ubicación es siempre en la planta baja del convento.

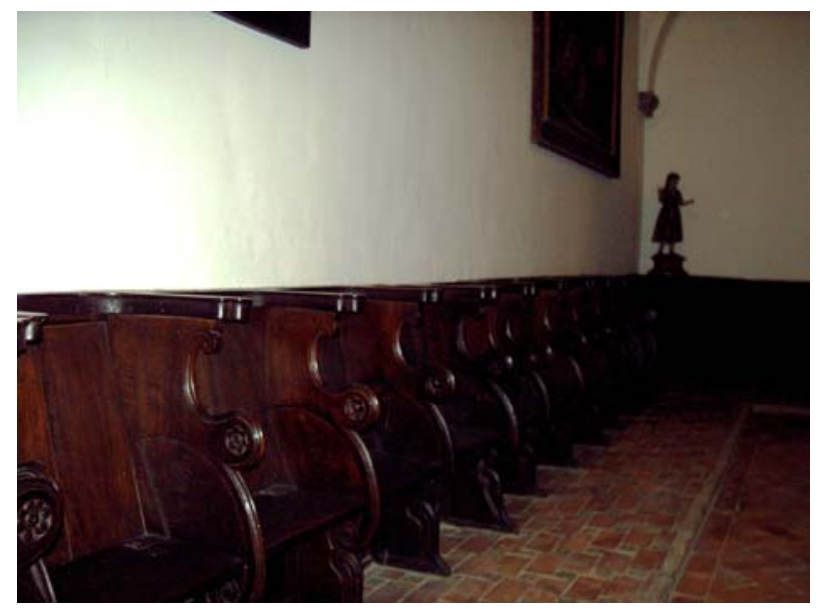

Sala Capitular del Monasterio de San Jerónimo.

\subsection{Sala de Capítulo de Culpas.}

Desde el claustro se accede a la sala de Capítulo de Culpas a través de una portada renacentista con columnas dóricas. La sala, rectangular, tiene iluminación natural, mediante dos vanos circulares que se encuentran en uno de los lados de la pared. Presenta un banco corrido, de fábrica, adosado a los muros laterales.

En esta sala se encuentra el enterramiento de Fray Pedro Ramiro de Alba, monje jerónimo, que fue el quinto arzobispo de Granada y murió en 1528. 


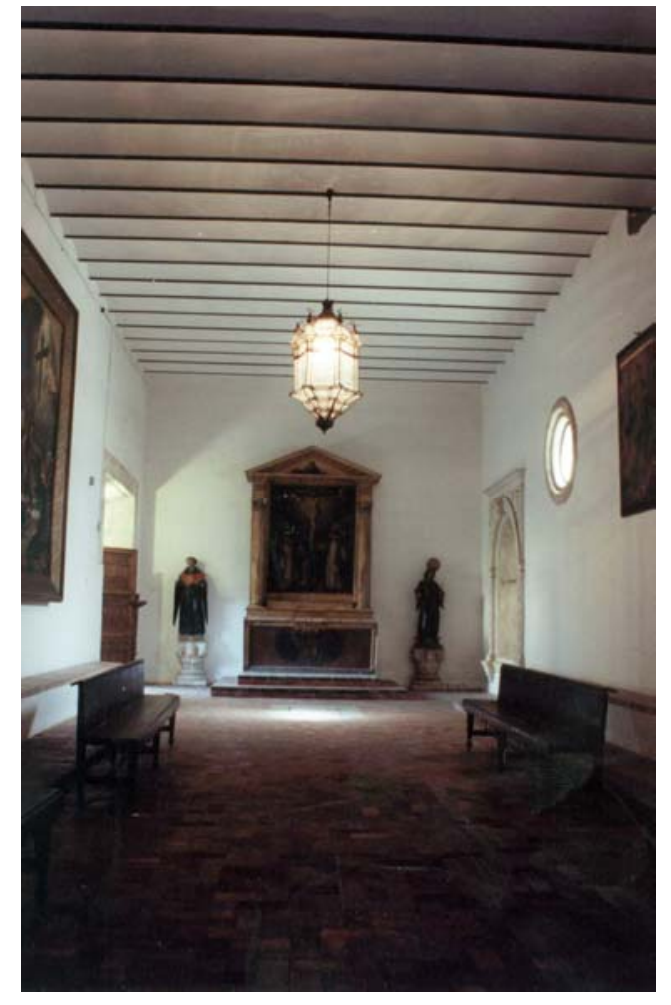

Sala del Capitulo.

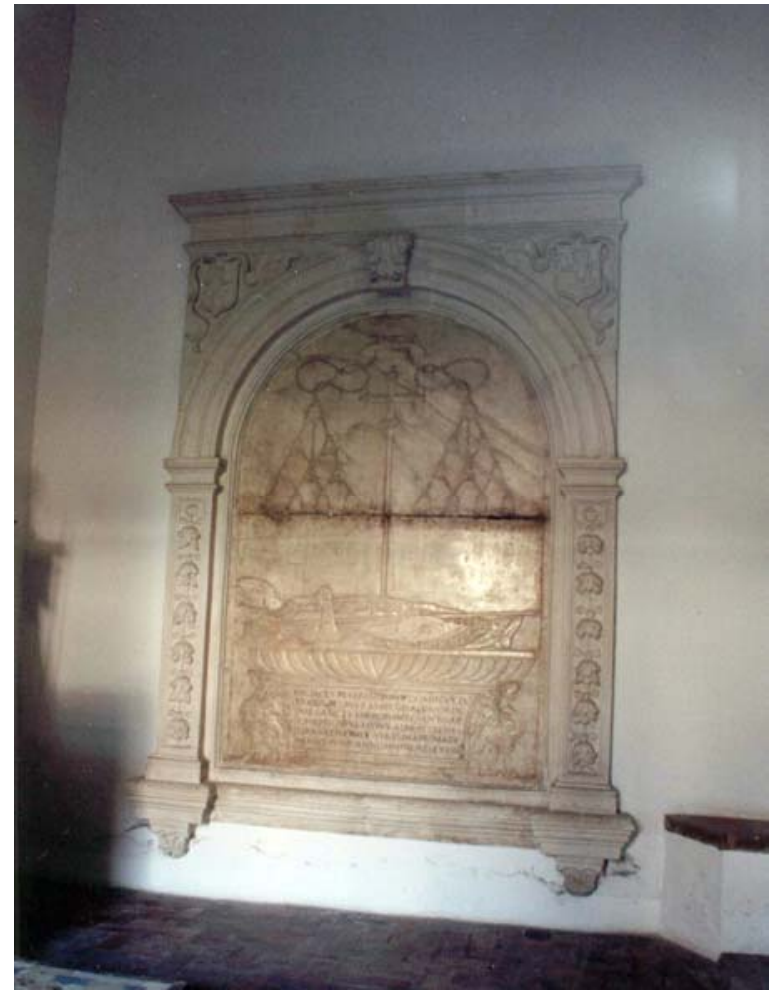

Sepulcro de fray Ramiro de Alba.

\subsection{Sacristía.}

La portada es de marcado acento renacentista decorada con el escudo del Cardenal Mendoza y la inscripción Ave María Gratia Plena. Localizada junto al presbiterio, solía constituir en los monasterios una dependencia especialmente rica por su decoración.

En los monasterios masculinos éstas son mayores dimensiones que en los femeninos, lo que se debe a su función, la de servir de vestuario para revestirse los oficiantes de la Misa, por lo que como dijimos al hablar de las capillas, un número importante de monjes la van a utilizar, mientras que en los femeninos sólo va a ser utilizada por un capellán. También es el lugar de concentración de los monjes para salir en procesión al templo. 


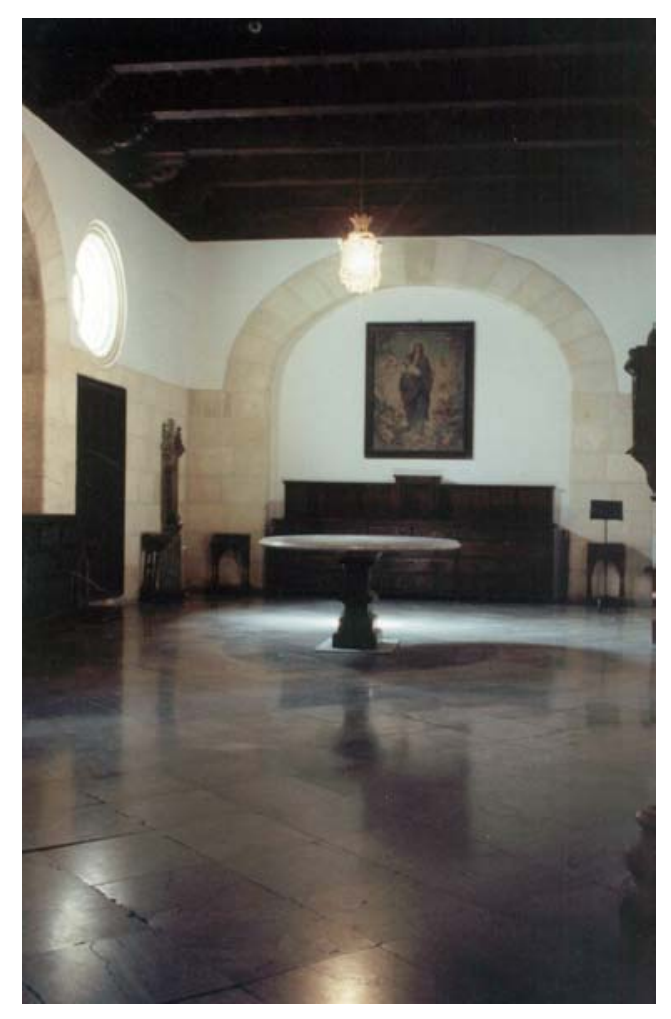

Sacristía Monasterio de San Jerónimo.

En la sacristía se guardan los ornamentos litúrgicos en armarios horizontales, llamados también cajoneras o calajes y los objetos litúrgicos y vasos sagrados en muebles verticales o armarios.

Debe existir, y siempre en un lugar preferencial un lavabo, en este caso una pila de mármol.

Todo ello debe estar presidido por un Crucifijo ante el que orará el oficiante antes de entrar al templo. Las imágenes que suele haber son de santos de la Orden.

También es en este espacio donde se encontraban los armarios relicarios, donde se guardaban las reliquias que se conservaban en el monasterio.

Tiene acceso desde el claustro. Es una pieza, desgraciadamente muy rehecha tras las diversas restauraciones, conservándose tan sólo un fresco de la Asunción de Juan de Medina, en el pasadizo por donde se entra en la Iglesia. Originariamente tuvo una columna gótica en el centro y allí se guardaban los grandes tesoros artísticos donados por los Reyes Católicos, así como por la viuda del Gran Capitán que dejó diversos retablos, ornamentos, banderas y joyas, destacando una cruz de oro con un Lignum Crucis. Todo ello desapareció en el saqueo de los franceses. 

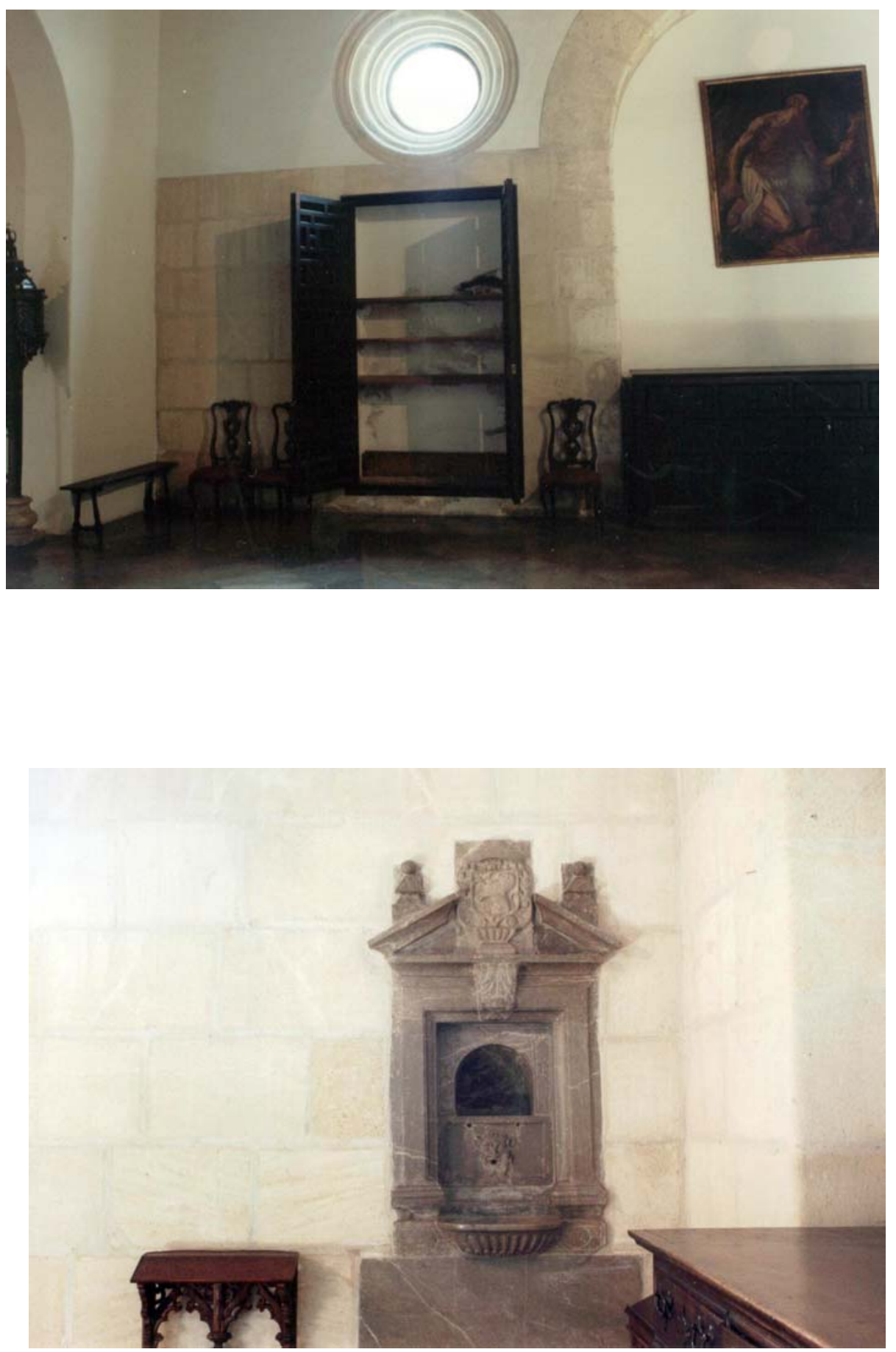

Armario y Pilar de la Sacristía del Monasterio de San Jerónimo. 


\subsection{La Iglesia.}

La iglesia es el centro de la vida espiritual y religiosa de la comunidad. Allí se celebran los oficios, las horas canónicas y demás obligaciones litúrgicas. Siempre se orientaban al Este, como todas las iglesias cristinas. Los monasterios que se encontraban en zonas urbanas, como en nuestro caso, cuentan con un amplio espacio al que pueden acceder los fieles, instalándose rejas para señalar aquellas partes donde no podía entrar el pueblo. Sin embargo, en las iglesias de monasterios rurales el espacio dedicado al pueblo era muy reducido, abriéndose las puertas en casos muy concretos.

De planta de cruz latina, con tres naves, crucero y ábside, que en los monasterios masculinos tiene un mayor desarrollo. Valladar indica que las proporciones de la iglesia "son verdaderamente suntuosas", "mide la iglesia 54,70 m. de largo y 22,68 de ancho, además del espesor de los muros" "35.
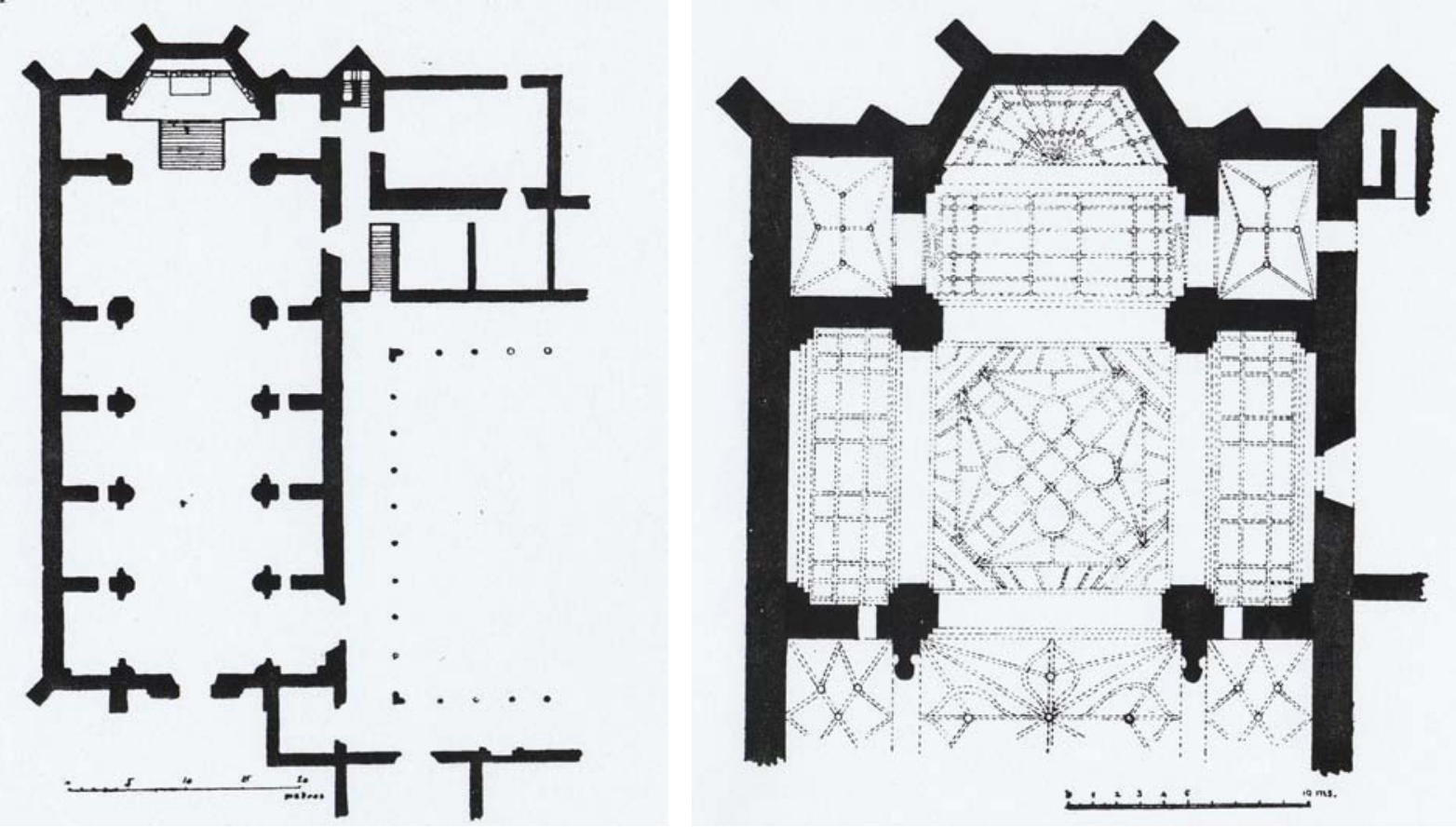

Planta y cabecera de la iglesia del Monasterio de San Jerónimo ${ }^{36}$.

\footnotetext{
${ }^{35}$ Valladar, F. [2000], p. 222.

${ }^{36}$ Gómez Moreno, M [1988], pp, 36 y 37.
} 
La iglesia que nació al calor de estas dependencias conventuales, en un primer momento, pertenecía al patronato real, pero don Gonzalo Fernández de Córdoba al otorgar testamento en 1515 pide ser enterrado en la capilla mayor del monasterio de San Jerónimo, al día siguiente el ilustre soldado murió. Su mujer, María Manrique, la duquesa de Terranova, deposita el cuerpo de su marido en el convento de San Francisco, y comenzó los trámites para solicitar la capilla mayor. Fue en 1525 cuando el Emperador otorgó esta merced.

La iglesia de Nuestra Señora de la Concepción presenta la clásica estructura de tradición gótica de una nave con capillas comunicadas entre sí, crucero, cabecera ochavada y coro a los pies en alto. La planta, aunque de mayores proporciones es igual que la de la Capilla Real, por lo que podría haber intervenido el arquitecto real Enrique Egas.

Tiene dos puertas, la principal a los pies de la nave, es la más solemne, por la que podía acceder el pueblo. La otra puerta, en el muro externo de una de las naves, está en el lado derecho, y nos lleva al claustro mayor del monasterio.

El templo, y más concretamente la capilla mayor, al ser cedido a doña María Manrique por Carlos $\mathrm{V}$, varió su función convirtiéndose en un templo funerario, acrecentándose de esta manera su parentesco con el enterramiento de los Reyes Católicos.

Al formalizarse el nuevo patronazgo, la duquesa de Sesa se obliga a realizar la capilla mayor, el retablo, la reja y el púlpito, así como los grupos sepulcrales yacentes de ella y su marido, en mármol o alabastro, que como en la Capilla Real se colocaría en la mitad del crucero. Para ello se dotó a las obras con 800 ducados anuales.

Seguidamente la duquesa nombró como arquitecto mayor de las obras al italiano Jacobo Florentino, que moriría al poco tiempo, en 1526. Pero aún así, le dio tiempo a modificar el estilo de la capilla mayor y comenzar su arranque, como el propio Diego de Siloé, posterior maestro de la Catedral de Granada, lo declara a la hora de hacerse cargo de las obras, en 1528.

Seguidamente la descripción que realiza Gallego y Burín ${ }^{37}$ : "Entre los pilares de su única nave, con cabecera semioctogonal, se abren cuadro capillas a cada lado, en las que trabajó, Florentino hasta su muerte y en las que, como en toda Iglesia, se conservó lo hecho hasta entonces, variándose, no obstante, los pilares redondos primitivos por pilastras corintias sobre pedestales, con decorados plintos y dragones a manera de volutas en los capiteles. Dos de las seis capillas tienen arcos apuntados y las otras seis paineles, de gusto ojival, cubriéndolas bóvedas muy sencillas de igual estilo. La de la nave es de crucería, con arcos semicirculares sobre columnas de basas dóricas y filetes por capitel: el tramo de los pies de esta nave está dividido en su altura por el coro, que tiene bóveda,

\footnotetext{
${ }^{37}$ Gallego y Burín, A. [1996], pp. 289-293.
} 
también de estructura ojival, moldura más ricamente y decorada en las enjutas de su arco con los emblemas de los Reyes Católicos. El friso tiene medallones con cabezas y parejas de medio cuerpo de hombres barbudos con capacetes y hachas, todo obra de Florentino, quien en los lados de la capilla mayor rehizo los arcos de las dos laterales, ricamente decorados, y en cada uno de los extremos de la nave del crucero labró retablos de piedra con tres hornacinas aveneradas -la cetnral más alta-separadas por columnas estriadas, cuyos capiteles unen con el finísimo friso, y todo soportado por fuerte repisa apoyada en capiteles jónicos y otros motivos decorativos.

Toda esta parte del templo debió dirigirla Siloé hasta su terminación, conforme a los proyectos de Florentino, arrancando del cornisamiento general su laboral personal que, desde ahí, pudo desenvolverse libremente, marcando con su genio la obra de la nave del crucero y la de la capilla mayor. En los hastiales de la primera, triples ventanas arqueadas, decoradas en las enjutas con figuras desnudas de hombres apoyados en troncos de árboles, se cobijan bajo bóvedas de cañón con artesones ornamentados con figuras, monstruos, medallas y rosetones, repitiéndose el tema en el primer tramo de la capilla mayor, cuya cabecera se cierra con otra bóveda de tres cascos, análogamente ornamentada.

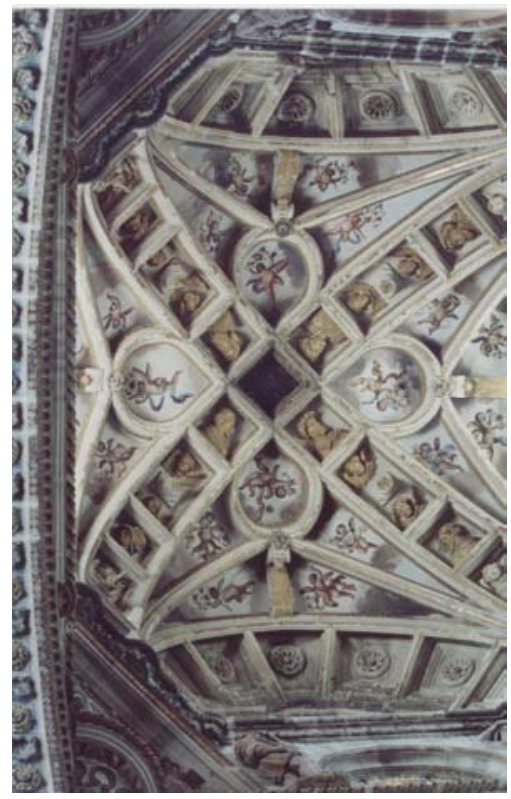

En el centro del crucero se alza el cimborrio y en las enjutas de los arcos que lo sostienen está repartida esta inscripción "Temp. prim. in hoc regno dicta. Pae. Vs. Ma. concepi. a MDXIX" y, encima claraboyas redondas con sátiros y hombres barbudos a los lados. La bóveda es de crucería con dobles ojivas y arcos formeros apuntados que contrastan con el resto de la decoración, tal vez, porque Siloé temió cargar demasiado el edificio si hubiese escogido otra estructura; las trompas sobre las que se levanta tienen forma de veneras, haciendo de hornacinas, en las que aparecen sentadas las imágenes de los Evangelistas sobre repisas circulares sostenidas por ángeles mancebos. Entre las ojivas hay artesones con bustos y querubines, prodigándose en todas partes las esculturas con la más extraordinaria variedad:

en las bóvedas de los brazos del crucero figuran en lato relieve héroes y heroinas de la antigüedad, cuyas hazañas se comparan con las del Gran Capitán y su esposa (César, Aníbal, Pompeyo, Marcelo, Marco, Tulio, Homero, Mario, Scipión,....Abigail, Judith, Débora, Esther, Hersilia, Armisa, Penélope, Alcesti...) alternando con angelillos, bichas y otras figuras caprichosas, y los cascos de la bóveda de la capilla mayor, tienen, asimismo, figuras de bulto del Salvador, los Apóstoles y ángeles con atributos de la Pasión y relieves de las Santas Bárbara, Catalina, Magdalena, Lucía, Paula y Eustoquia y los Santos guerreros, Jorge, Sebastián, Martín, Eustaquio, Francisco y Pedro Mártir. En los retablos altos de 
los lados del crucero, que hizo Florentino, colocó Siloé grandes escudos de armas de los fundadores en la hornacina central, soportados por figuras de hombres, otra de las cuales hay en la venera $y$, en las hornacinas laterales, parejas de lansquenetes, coronando uno y otro angelotes y las estatuas sentadas de las Virtudes Cardrinales. Bajo el retablo de la derecha hay una portadilla que comunicaba con el Monasterio, también de Siloé, muy adornada, con cornisa apoyada en ménsulas a la manera clásica y, bajo el de la izquierda, se hizo, en 1795, y unido a él, otro retablo de estuco con cuatro columnas jónicas, al que se adaptó en aquella fecha un frontal italiano de mármol, del siglo XVI, con cabezas en medallones y finos adornos italianos, que antes sirvió de base al grupo del Entierro de Jacobo Florentino y que actualmente se encuentra en el claustro, ocupando su lugar un frontal procedente del altar mayor de Santa Paula. En este retablo destacan, una imagen de la Virgen con Niño, obra del escultor flamenco Roque Balduique y a sus lados San Jerónimo y Santa Paula, estatuas granadinas del siglo XVII, ambas procedentes del Monasterio de Santa Paula, así como las estatuitas de San Miguel y San Gabriel, de escuela de Ruiz del Peral; y hallándose dos lienzos de Juan de Sevilla, a ambos lados de la capilla mayor. Los altares colaterales del crucero tuvieron retablillos pintados por Pedro de Raxis, a uno de los cuales perteneció la escultura de San Jerónimo que aqui se conserva, a obra del siglo XVI y actualmente en el retablo de la capilla, de Díaz Sánchez Dávila; y todas las ventanas del templo las cerraban vidrieras con escenas de la vida de Jesús, pintadas, al parecer, por Arnao de Vergara, restos de una de las cuales quedan bajo el cimborrio, con la figura de San Ambrosio, y dos, completas. Otras dos, completas, que dan al coro fueron también descubiertas en 1942, y actualmente una de ellas en el Museo de Bellas Artes.

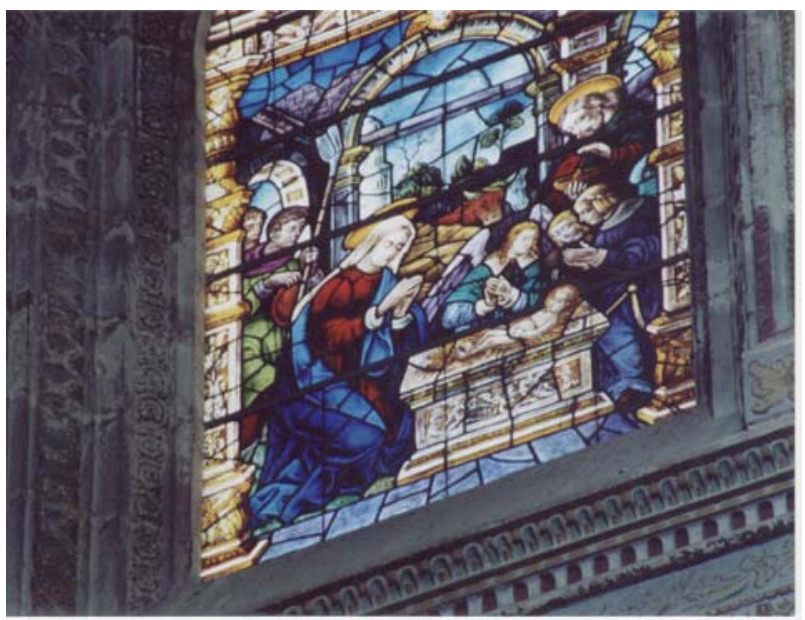

Adoración.

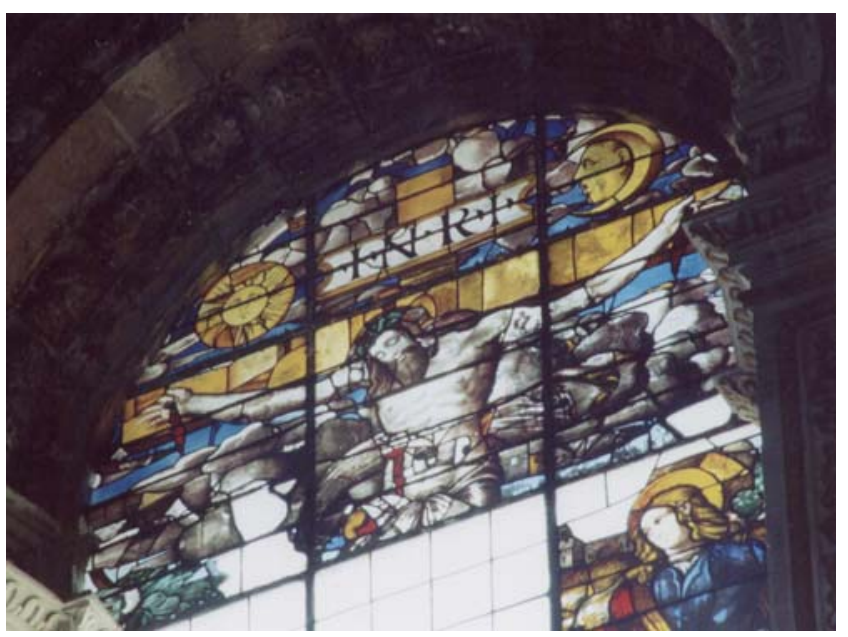

Calvario

Vidrieras de la iglesia del Monasterio de San Jerónimo 
En el siglo XVIII se pintó todo el templo, embadurnándose las esculturas de Siloé y cubriéndose las naves con frescos, algunos de ellos excelentes, realizados por Juan de Medina en 1723, año en el que firmó los del crucero, en 1727, 1729 y 1735 los de las bóvedas.

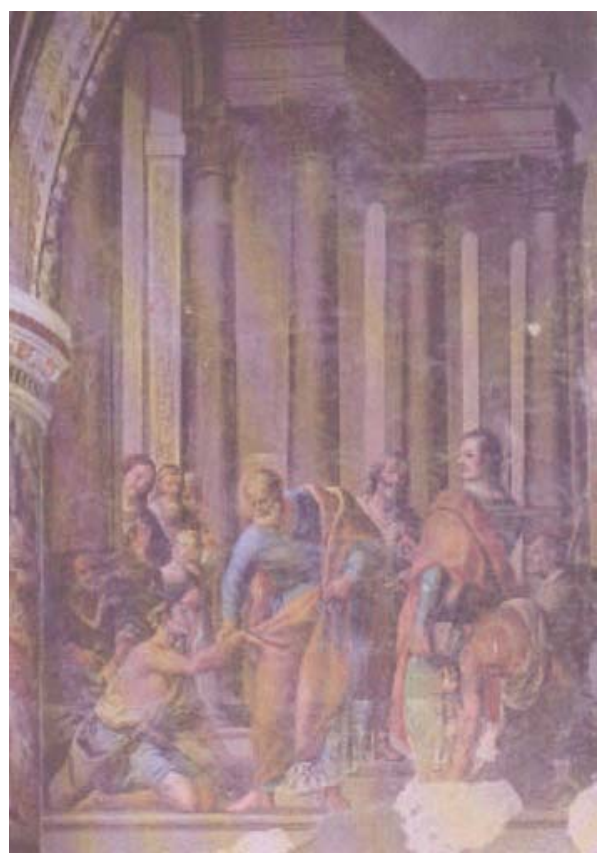

San Pedro curando a un tullido.

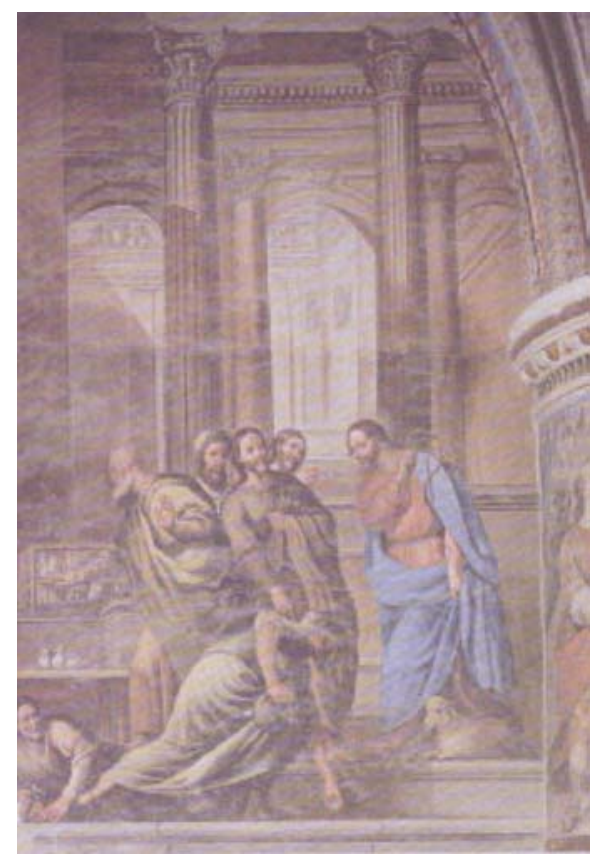

Expulsión de los mercaderes de templo.

Iglesia del Monasterio de San Jerónimo.

En éstos figuran grupos de angelillos, y junto a las ventanas, Padres de la Iglesia Latina, escenas de la Crucifixión y tribunas con ángeles músicos y cantores; en las columnas hay figuras de arcángeles y, a los lados de la puerta, Jesucristo arrojando a los mercaderes del Templo y San Pedro curando al tullido $y$, en fin, en el crucero, las pinturas imitan tapices con el Nacimiento y la Adoración de los Reyes, la Venida del Espíritu Santo y la muerte de la Virgen y, entre nubes y ángeles, los Santos Tomás de Villanueva y Agustín, la Inmaculada, la Virgen y el Niño, etc. Las paredes laterales de la capilla mayor también tiene grandes frescos con escenas de la vida del Gran Capitán: el lado del Evangelio representa al Papa Alejandro VI bendiciendo y entregando al héroe la espada que le regaló para defensa de la Iglesia, que tenía empuñadura y vaina de plata sobredorada y esmaltes en verde con adornos y las armas pontificias, figurando debajo esta inscripción: "Alex. VI. P.M. benedicit glaudium donatque illum magno duci, uti defensori Ecclesiae. Pontificatus sui anno primo”. La espada, que estuvo aquí, sobre la pintada mesa del cuadro, fue robada en 1622 y sustituida por otra 
de madera, refiriéndose que fue recobrada y, luego, definitivamente sustraida por el General francés Sebastián, en 1810.

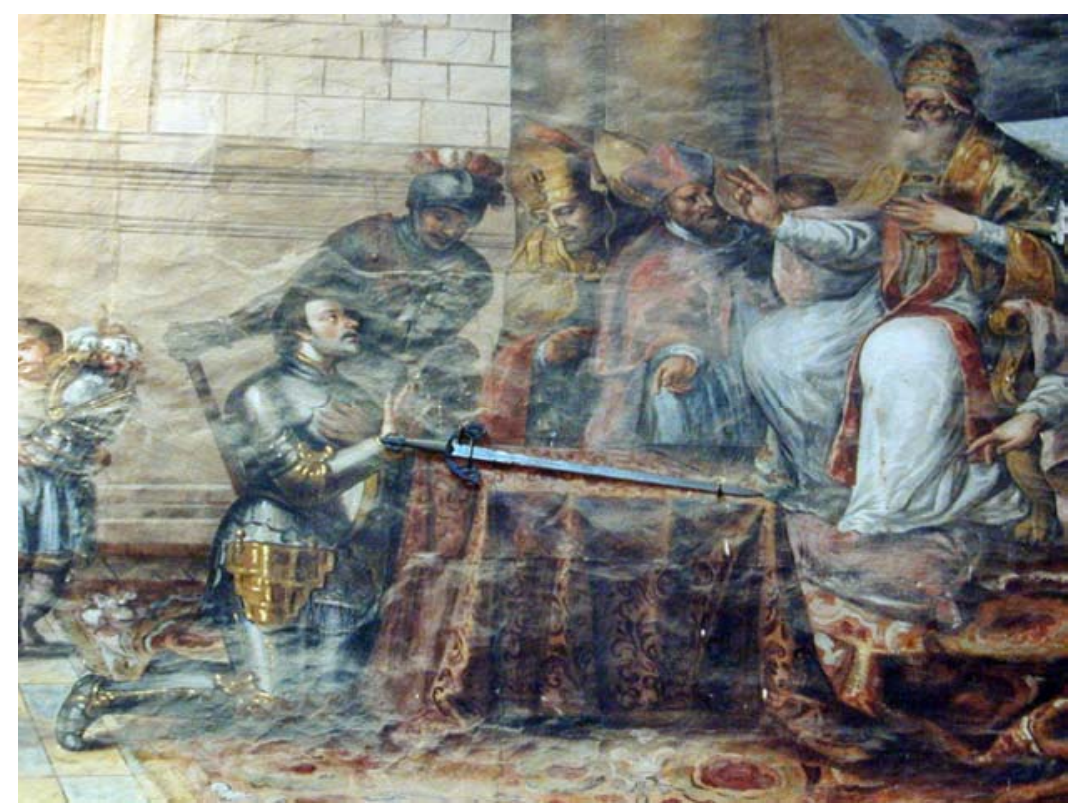

El papa Alejandro VI entrega al Gran Capitán una espada.

En el lado de la Epístola estuvo colgada otra espada, que ordinariamente llevaba el caudillo y que en el s. XVII entregó uno de los priores a sus descendientes y, bajo él, figura esta inscripción: "Gregorius XII P. M. al preces ex ducis II Suessede innumeras huic templo concedit gracias. Pont, sui anno IV". Las capillas de la naves tenían, asimismo, pinturas murales bastante malas, hechas en el s. XIX pro un tal Plazas, menos las dos últimas que se conservan, y son obras apreciables de Martín de Pineda Ponce.

Entre las obras situadas en las capillas, caben destacar un Cristo a la columna y un San Pedro arrodillado ante él, los dos de gran tamaño, buenas muestras de la imaginería andaluza de fines del quinientos, una Soledad de vestir, del estilo de la escuela de Risueño, s. XVIII, un notable Cristo yacente de la escuela de los Mora, una imagen de la Virgen de Belén, del círculo de los Mora, una interesante escultura de San Miguel, del XVII, muy deteriorada, y un lienzo de San Cristóbal de Bocanegra o de Guevara, todo esto procedente del Monasterio de Santa Paula. También se encuentran en las capillas un San Francisco de Paula, procedente de San Escolástica y una imagen de San Pío V, procedente de la colección del Duque del Infantado; y en fin en la capilla junto al púlpito de mármol rojo, donde está la sepultura del Conde de las Infantas, hoy un cuadro de la Inmaculada con las almas del purgatorio, posiblemente de Alonso Cano". 


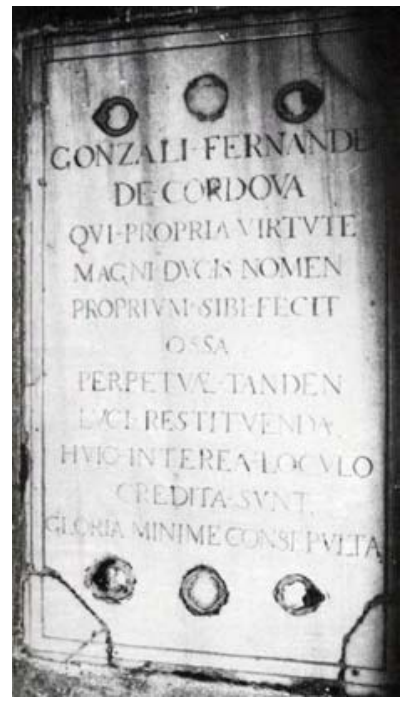

Al pie del Altar mayor, en el centro de la nave del crucero, sobre el pavimento, se ve la lápida bajo la cual reposan los restos del Gran Capitán, en la losa de mármol aparece grabado el siguiente epitafio: "Gonzali fernández/De cordova/Qvi propia virtute/Magni dvcis nomenn/Propivm sibi fecit/Ossa/Perpetvae tanden/Lvci restitvenda/Hvio interea locvlo/Credita svnt/Gloria minime consepvlta".

Lo traducimos de la siguiente forma: "Los huesos de Gonzalo Fernández de Córdoba que, con su valor, se apropió el sobrenombre de Gran Capitán, están confiados a esta sepultura hasta que al fin sean restituidos, a la luz perpetua. Su gloria no quedó sepultada con él".

Algo retrasadas, en el centro de la nave, se encuentran indicadas otras tumbas, sin duda son las de doña María Manrique, la de su hija doña Elvira y la de su esposo el duque don Luís.

El Gran Capitán fue sepultado, en principio en San Francisco de la Alambra, cuando se otorgó la gracia de enterramiento y patronato en esta iglesia a la duquesa de Sesa y Terranova para su marido, ella y sus descendientes por el emperador Carlos, fueron trasladados hasta aquí con gran pompa en virtud de la cédula de 7 de marzo de 1525, previa aprobación por el capítulo de la Orden Jerónima de 1523, realizándose la traslación el día 4 de octubre de 1525. 


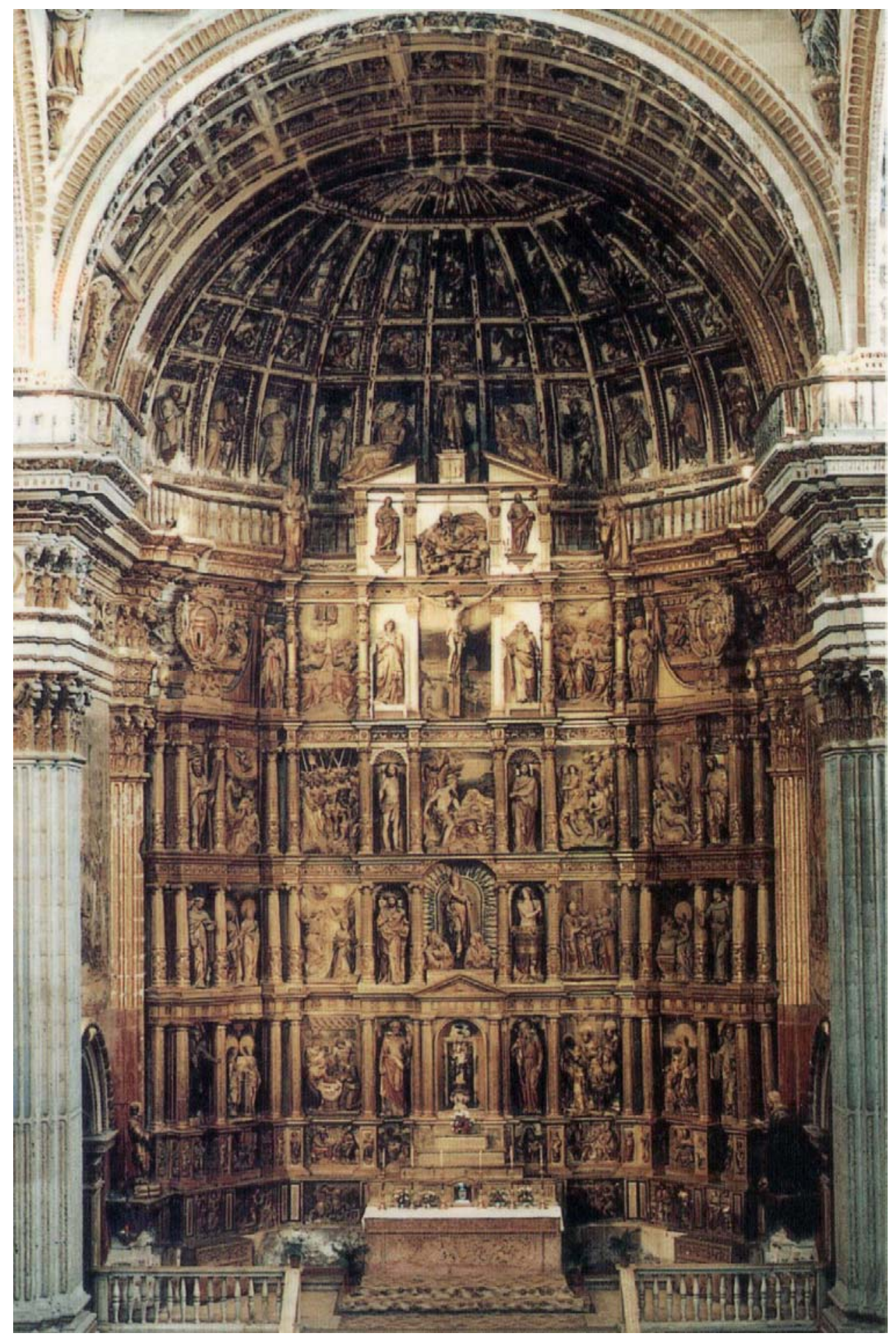

Retablo de la Capilla Mayor, iglesia del Monasterio de San Jerónimo. 
Estuvieron en este lugar hasta que las tropas napoleónicas del general Sebastiani profanaron las tumbas.

Cuando el monasterio quedó abandonado, durante la exclaustración, los restos que quedaban fueron recogidos por la Academia provincial de Bellas Artes, junto con restos de "calzado, ropas de seda y terciopelo y madera de cedro de las cajas". Estos restos se conservaron en diferentes lugares, pero por orden de la reina Isabel II el 26 de abril de 1857 volvieron a Granada, al Monasterio de San Jerónimo.

Se decidió construir un Panteón municipal de españoles célebres en Madrid, por lo que reclamaron los restos de Gran Capitán de nuevo. Ya, por último, en 1874 la Comisión granadina de monumentos los llevo de nuevo a San Jerónimo, donde se encuentran en el interior de una caja de plomo.

La capilla mayor, se asciende hasta el altar mayor mediante una elevada escalinata, éste estaba situado tan alto para que los monjes pudieran asistir a las celebraciones desde el coro. La barandilla de mármol blanco de la escalinata procede de un convento sevillano. Todo el fondo del presbiterio está ocupado por el retablo mayor, que constituye una de las obras maestras de la imaginería española, punto de arranque de las escuelas de escultura de Granada y Sevilla ${ }^{38}$.

Este magnífico retablo, de tres hojas, debería haber sido obra de Diego de Siloé, pero los enfrentamientos que tuvo con el nieto del Gran Capitán, lo impidieron. Fue comenzado hacia el año 1570 , sobre la traza del pintor Juan de Aragón y el escultor Diego Pesquera. Sufrió varias alteraciones, la primera de las cuales fue realizada por Lázaro de Velasco, hijo de Francisco Florentino. Más tarde el ya alterado diseño fue objeto de una segunda rectificación por parte de Pedro de Orea.

La realización escultórica con cierto fundamento se atribuye a Diego de Navas y a Bernabé de Gabiria. También se atribuye algún trabajo en el retablo a Pablo de Rojas y a su discípulo Montañés, y se asigna alguna parte del mismo a Juan Bautista Vázquez "el mozo", a quien se atribuyen los relieves de la Anunciación, la Epifanía y la Circuncisión, así como alguna escultura. Pese a la intervención de todos estos artistas el conjunto del retablo tiene armonía.

Los cuerpos del retablo se alzan sobre un sotabanco decorado con relieves de San Esteban, San Lorenzo, Santa María Egipcíaca, Constantino, San Martín, San Cosme, San Damián y otras dos santas más.

Sobre el anterior, se apoya el banco del cuerpo primero, que tiene en los pedestales figuras de Santas mártires y en los tableros relieves de los Evangelistas y Doctores San Bartolomé y San Ildefonso.

\footnotetext{
${ }^{38}$ Gallego y Burín, A. [1996], p. 291-293.
} 


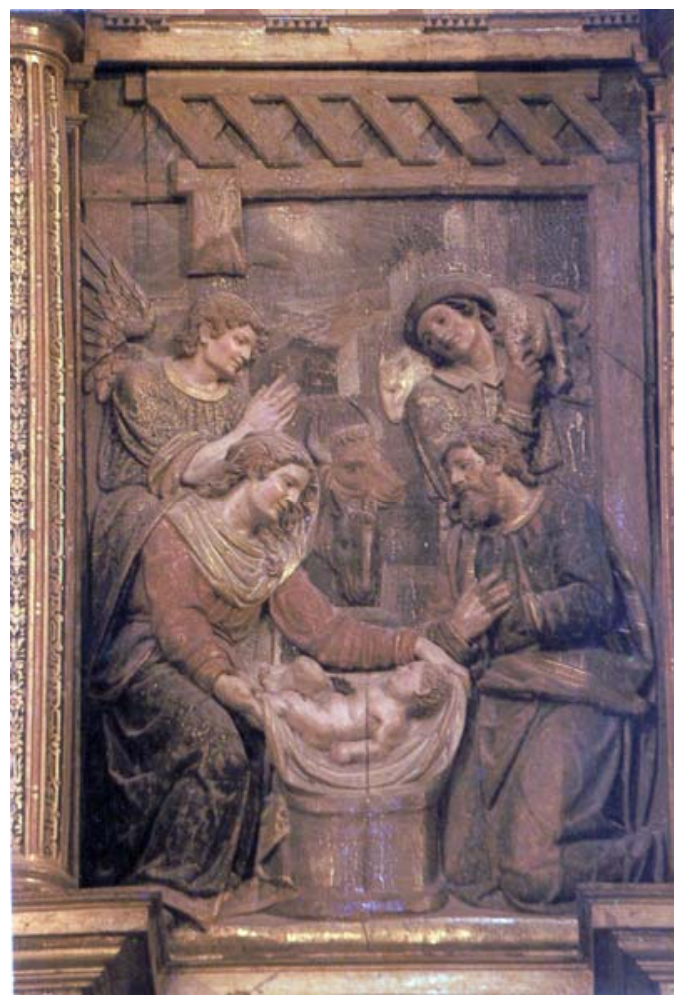

Adoración, detalle del retablo Mayor de la iglesia del Monasterio de San Jerónimo.
El primer cuerpo, de orden dórico, con columnas estriadas, está centrado con un frontón en el que se encuentra la obra muy posterior del sagrario, donde se ha situado una Virgen con Niño, del siglo XVI, procedente del Monasterio de Santa Paula de Granada. En este cuerpo destacan los relieves de la Natividad, Epifanía, los apóstoles Pedro y Pablo, $\mathrm{y}$ las santas Catalina, Bárbara $\mathrm{y}$ Margarita y en las columnas de los extremos laterales los santos Benito y Bernardo.

En el cuerpo principal se ve una Inmaculada del siglo XVIII, y a sus lados figuran San Joaquín y Santa Ana, entre columnas jónicas, que coincidiendo con el ático, y rompiendo los frisos de los distintos cuerpos, hacen resaltar la parte central de cada hoja. En ambos costados los Santos Juanes, el Bautista y el Evangelista, San Francisco de Asís, Santo Domingo de Guzmán y relieves de la Anunciación, la Presentación del Niño Jesús en el templo y las santas Paula, Eustoquia y María Magdalena.

El tercer cuerpo está centrado con un San Jerónimo penitente y a los lados y entre columnas jónicas un Ecce Homo y un Jesús a la Columna, San Andrés y Santiago, relieves de la Oración en el Huerto, Prendimiento, Encuentro de Jesús con su Madrid-Quinta Angustia- y la Crucifixión.

Sobre este cuerpo se sitúa otro, también corintio, en cuyo centro aparece el Calvario (Cristo crucificado, San Juan y la Virgen), los relieves de la Ascensión y la Venida del Espíritu Santo, las virtudes de la Prudencia y la Justicia y los escudos del Gran Capitán y su esposa, doña María Manrique. 


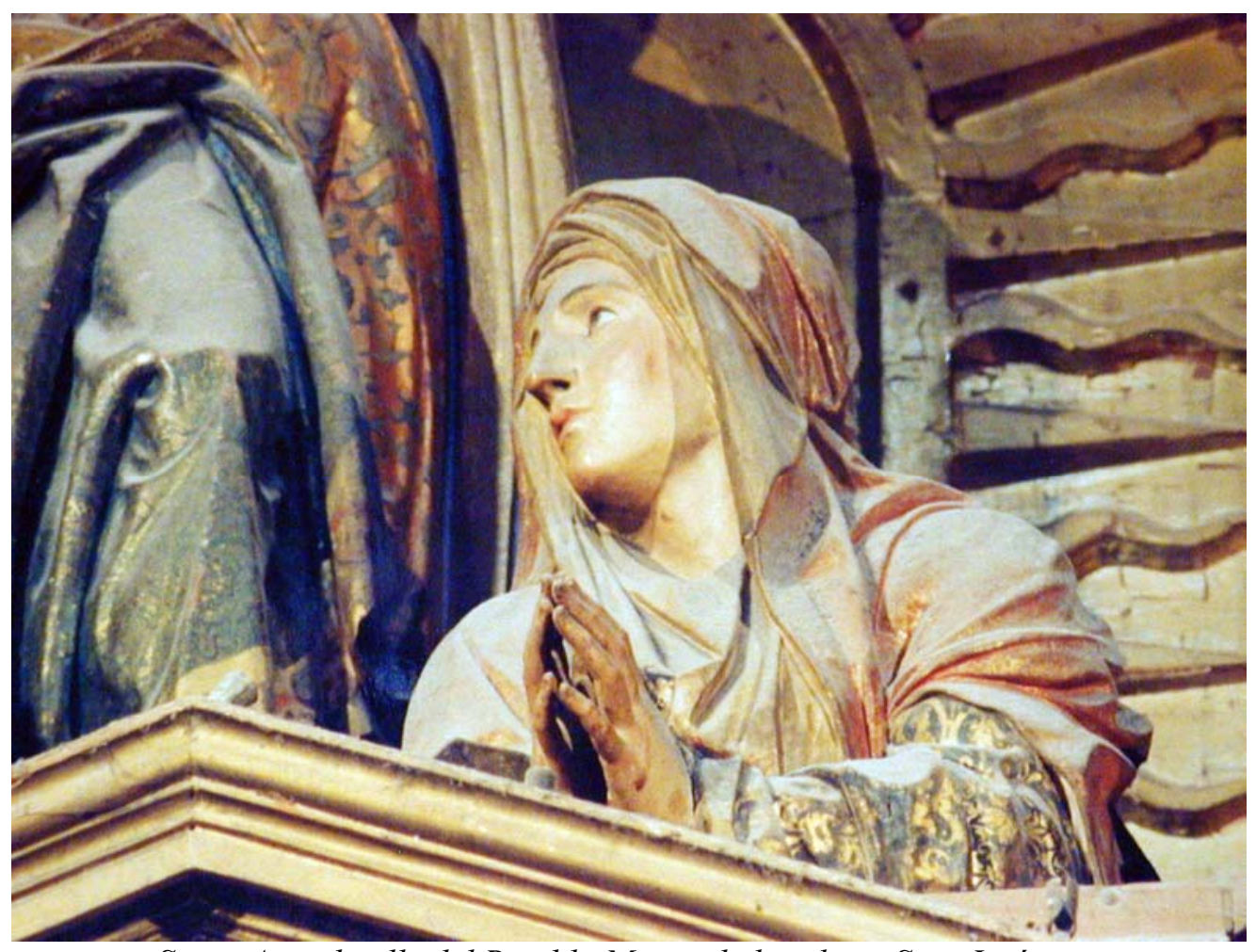

Santa Ana, detalle del Retablo Mayor de la iglesia San. Jerónimo.

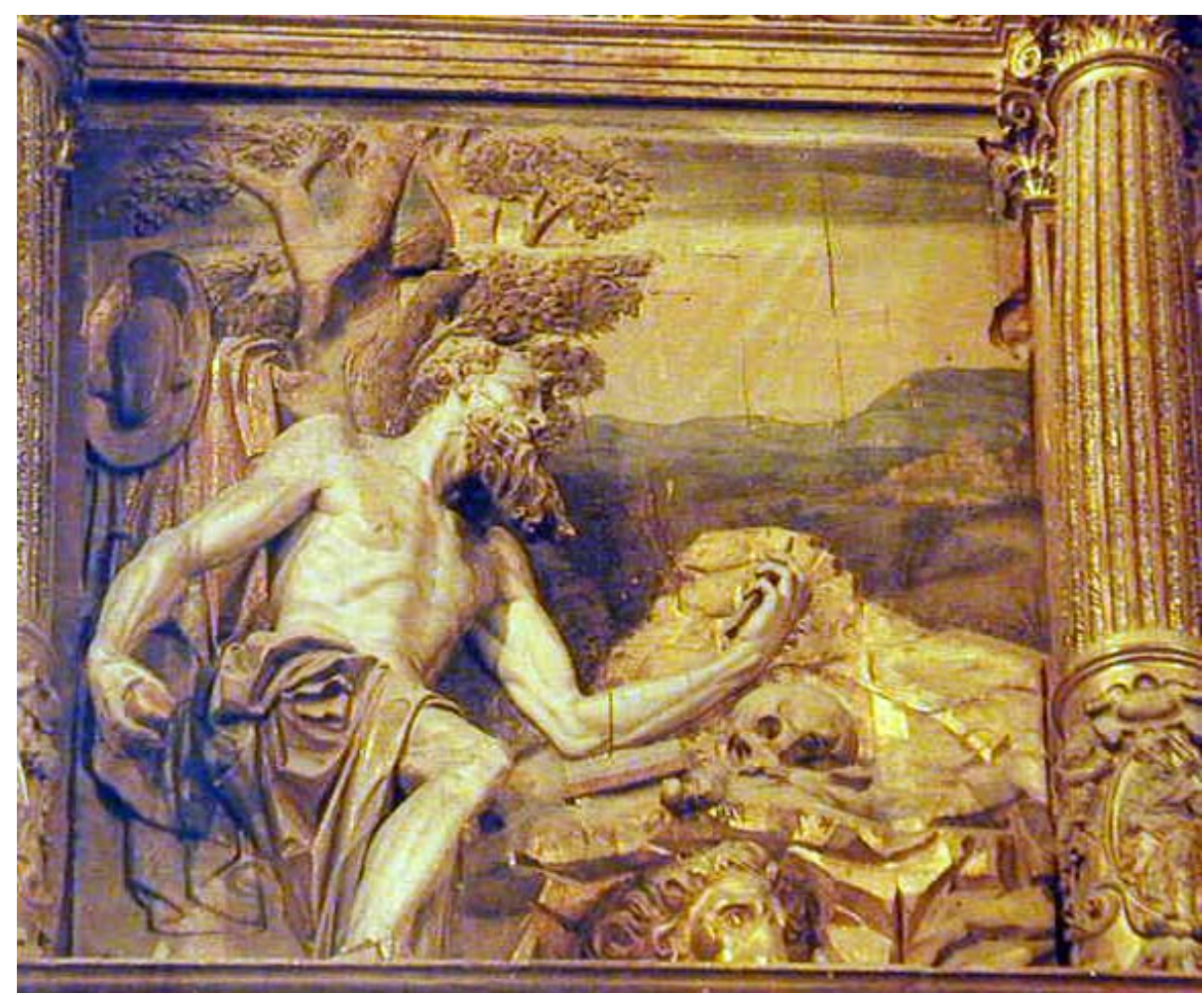

San Jerónimo, detalle del Retablo Mayor de la iglesia de San Jerónimo. 
En el ático aparece la figura de Dios Padre, los Santos Justo y Pastor, y las figuras de la Fortaleza y Templanza. La obra está coronada por las figuras de la Fe, Esperanza y Caridad.

A ambos lados del retablo, en actitud orante, se encuentran las figuras de Gonzalo Fernández de Córdova y de su esposa María Manrique.

En las capillas que hay a los laterales del presbiterio, se encontraban unos altares con relicarios, en los que entre otras alhajas estaba la Cruz de Fray Hernando de Talavera.

En cuanto al Coro, en los monasterios de varones este adquiere una importancia capital, y siguiendo la tradición hispana se localiza en el centro de la nave principal, en algunos casos el coro es bajo, pero en la mayoría y es nuestro caso el coro está en alto. Esto determina que la puerta este casi siempre a los pies del templo.

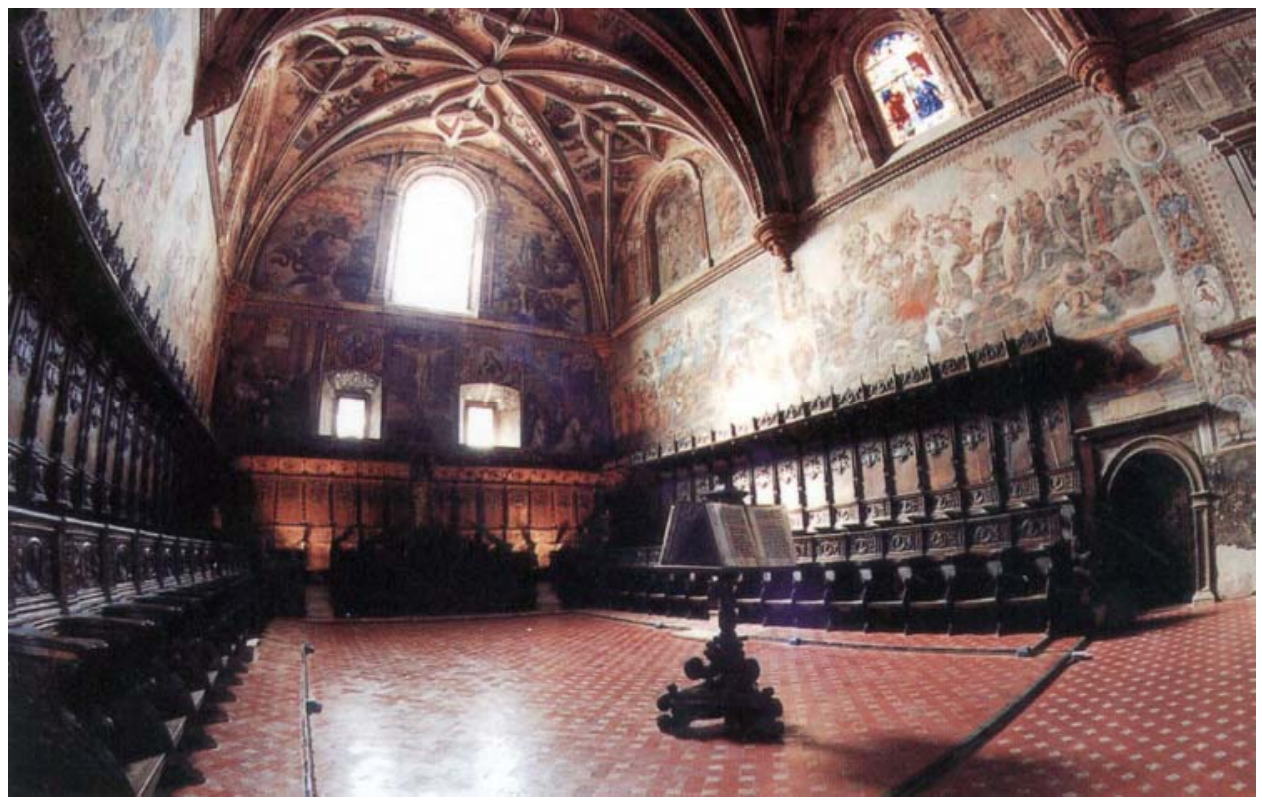

Coro de la iglesia del Monasterio de San Jerónimo

Señalar que en los monasterios o conventos femeninos, es frecuente encontrar el coro a los pies, tanto alto como bajo, y en muchas ocasiones es doble, es decir, tiene los dos tipos, así Santa Paula de Sevilla. El bajo, suele tener un comulgatorio provisto de reja para que la comunidad pueda recibir este Sacramento, se da también el caso de que el coro bajo aparezca de forma lateral, en uno de los lados del presbiterio.

El coro se configura por la sillería coral (en algún caso llega hasta tres filas de asientos), en la mayoría de monasterios españoles nos encontramos con sillerías de una gran belleza de talla, con profusión ornamental y complicados programas iconográficos, que aparecen en todas sus partes, así tableros de respaldos, 
brazaletes y misericordias, una especie de pequeña ménsula que sobresale bajo el asiento levantado y que sirven para hacer más llevaderas las largas estancias corales, con partes del rezo o de liturgia que deben efectuarse durante bastante tiempo.

Entre los asientos destaca la silla prelacial, destinada al prior del monasterio, ésta presenta mayor altura y mayor decoración.

En el centro del coro se situaba el facistol, un gran atril giratorio, construido en madera y enriquecido por otros materiales, destinado a sostener los grandes libros de coro.

Se accede a él por el claustro alto, se conserva la espléndida sillería de nogal realizada en 1544 por Diego de Siloé, con dos series de asientos ricamente decorados, con relieves de bichas en los brazos de los extremos y tableros con cabezas y adornos tallados en los espaldares, que en la serie están rematados por guardapolvos con rosetones y crestería de medallones y bichas, recorriéndose con cintas en los que se leen versículos de Salmos.

Particular interés tiene la silla prioral, con un relieve de la Virgen con el Niño rematada por el Padre Eterno, y guardapolvo con frontón, decorado con unos niños recostados. El relieve original de la Virgen con el Niño (D. Siloé), se encuentra hoy el Museo de Bellas

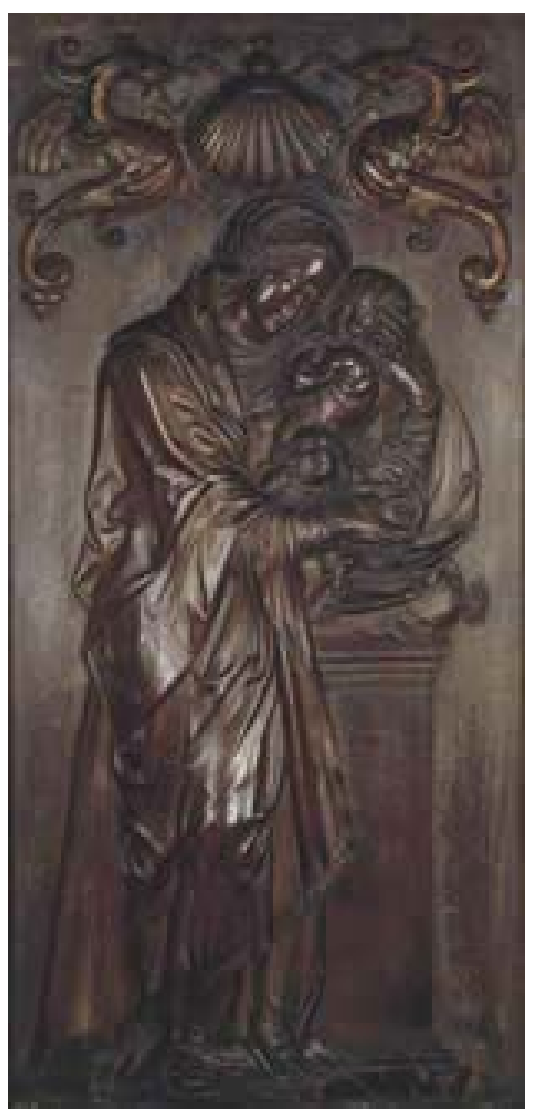
Artes de Granada. 
Las paredes del coro están todas decoradas, al igual que el resto de la iglesia, con murales de Juan de Medina, en ellos se representan escenas bíblicas y otros asuntos de tema religioso, así la Virgen acompañada de las Santas Mujeres, los Santos Padres, el Triunfo de la Eucaristía y el de la Iglesia y, en el centro del testero un Cristo de la Expiración del testero un Cristo de la Expiración, episodios de la Orden, y una Asunción y una Inmaculada y, grupos de ángeles.

Al realizarse estas pinturas se taparon las ventanas que tenía el coro, decoradas con vidrieras del siglo XVI.

Destaca el pavimento, a base de olambrillas, azulejo decorativo de unos siete centímetros de lado, que se combina con baldosas rectangulares, generalmente rojas, para formar pavimentos y revestir zócalos ${ }^{39}$, vidriadas del año 1543.

Respecto a los órganos, a los lados del Coro se encuentran unos arcos de piedra con labra romana, en los que se ajustaban los órganos primitivos, pero en la actualidad se encuentran ocultos por unas tribunas que fueron añadidas en el siglo XVIII, para colocar unos órganos nuevos, aunque de éstos sólo quedan las cajas.

\subsection{Capilla de la Torre.}

El diseño de la capilla, al igual que el resto de capilla del claustro mayor fue obra de Diego de Siloé, aunque probablemente la ejecución fuera obra de algún discípulo suyo.

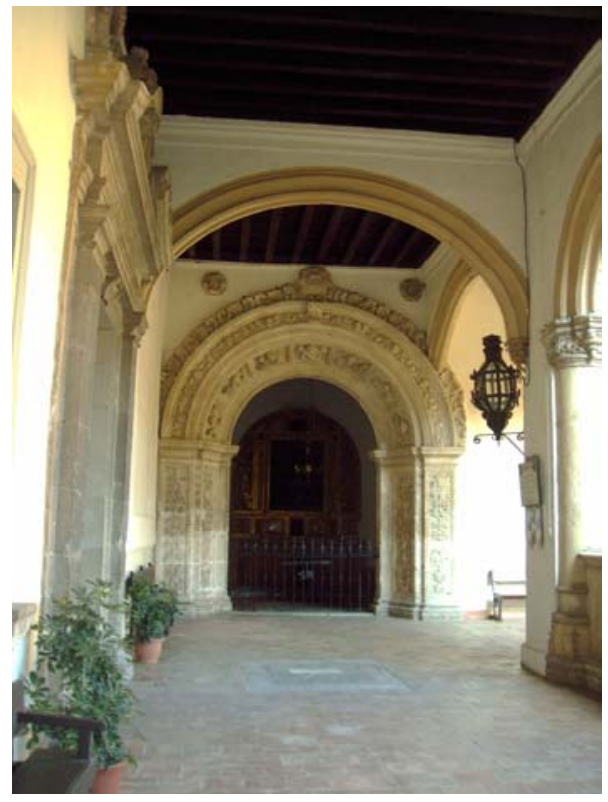

Esta capilla, abocinada, presenta una portada cuya decoración es una síntesis iconográfica de las preferencias monacales y cortesanas, son figuras en relieve de medio cuerpo, distribuidas de una manera: culmina en el embocinado con un Ecce Homo sobre el óculo de la clave, descendiendo con los santos Juan Bautista, San Juan Evangelista, San Pedro y San Pablo, San Gregorio y San Jerónimo. Mientras, la arquivolta, las jambas y las pilastras están bellamente decoradas con motivos platerescos.

Ya en su interior, la bóveda de la capilla está decorada con pinturas al fresco en las que se representan a los cuatro Evangelistas y un pequeño retablo.

\footnotetext{
${ }^{39}$ Real Academia Española, [1996], p. 1473.
} 
A continuación, incluimos algunos de los espacios que existían en todos los monasterios de la Orden Jerónima, pero aunque hoy no existen en San Jerónimo, nosotros los incorporaremos al discurso expositivo.

\subsection{Una celda.}

En la segunda planta del claustro principal, se situaban las celdas de los monjes, entre ellas, destacaba la celda prioral, ésta estaba decorada de dos retratos de medio cuerpo de los Reyes Católicos jóvenes, una medalla en mármol del Gran Capitán con rótulo en cera, unas tablas del Crucificado y cabezas de San Pedro, San Pablo y San Jerónimo.

\subsection{Biblioteca.}

Hay que tener en cuenta que desde la Edad Media y, prácticamente, hasta los albores de la Edad Moderna, los monasterios fueron los santuarios de la cultura occidental, tanto humanística como científica, entendiendo esto comprenderemos la importancia que tuvo el Scriptorium, lugar donde se reunían los monjes para trabajar, constituyendo el centro de la vida intelectual del monasterio. En este lugar se llevaba a cabo el estudio de los códices y sus copias por los monjes, la única manera de difundir los conocimientos antes de que la imprenta naciera.

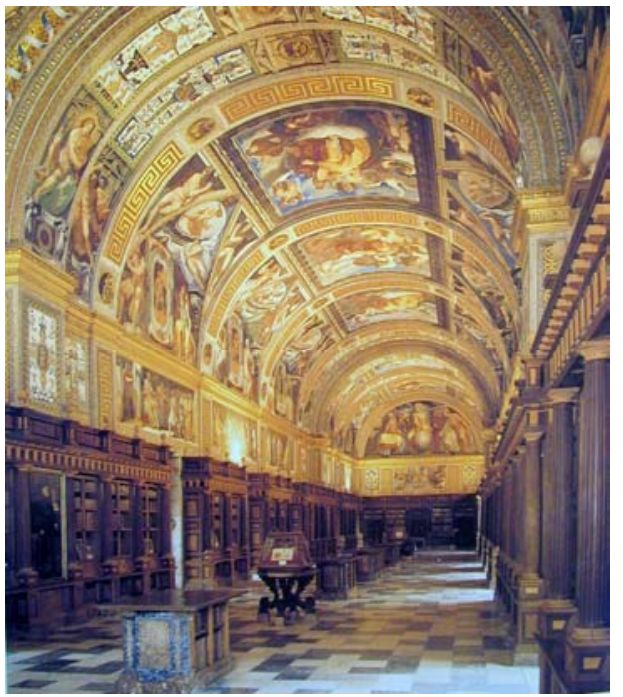

Biblioteca del Monasterio de El Escorial.

El mobiliario consistía en mesas de trabajo individuales, además de algunos estantes de obra o de madera donde iban dejando el material.

Con los años, se fue vinculando al scriptorium, la biblioteca, aunque en muchos casos no estuvo en el mismo lugar.

Las grandes bibliotecas de los monasterios españoles, salvo alguna excepción como la gran Biblioteca del Escorial, desaparecieron debido a las medidas desamortizadoras de 1835 y 1868, que acabaron con gran número de estos conjuntos culturales, algunas muy especializadas, perdiéndose miles de códices y libros impresos. Muchos pudieron salvarse, pasando a la incipiente, por entonces, Biblioteca Nacional, o a bibliotecas provinciales, seminarios y universidades.

Relacionado con lo anterior estaba el archivo, que servía para guardar los documentos propios del monasterio, bulas, privilegios, papeles diversos, libros 
becerro y de fábrica, etc. En algún caso esta dependencia ocupó un edificio exento para protegerlo en caso de que el monasterio sufriera un incendio.

La biblioteca llegó a poseer importantísimos fondos, entre los que destacaban 53 volúmenes manuscritos, con grandes caracteres, en vítela.

\section{El proyecto de iluminación.}

\section{- La iluminación general.}

La luz es uno de los elementos más importantes de un museo, ya que sin ella no podemos ver lo expuesto, "sin ella, la luz, los espacios resuenan a vació y no se revela ante nosotros en modo alguno la existencia de un entorno y de los objetos que éste contiene".

"La luz es la herramienta que nos permite describir la ordenación arquitectónica del espacio, y la distribución en él de los objetos. Es por tanto su uso el que va a determinar en gran medida la ortografia y la sintaxis con la que vamos a desarrollar la historia, mueble y material, la lectura que cualquier observador puede hacer de ese complejo discurso que es en esencia la exposición en un Museo",

Como ya hemos señalado en varias ocasiones, queremos que el programa museológico y el proyecto museográfico del Monasterio de San Jerónimo respete ante todo la arquitectura del edificio, lo que vamos a tener muy presente a la hora de elegir e instalar un determinado sistema de iluminación. Éste deberá mantener un equilibrio entre la conservación y la confortabilidad de los visitantes, a los que habrá que posibilitar la buena contemplación tanto del espacio arquitectónico como del patrimonio mueble que éste alberga.

Los criterios que hemos tenido en cuenta a la hora de elegir un sistema determinado han sido:

- Seguridad y fiabilidad en el suministro y en la instalación para que en todo momento se puedan satisfacer las necesidades de nuestro monasterio.

- Versatilidad de la instalación para posibles cambios y modificaciones en la ubicación de equipos, cambios de usos, etcétera, causando así el menor perjuicio al edificio.

- Diseño de la filosofía del sistema para asegurar el buen funcionamiento de los equipos en el futuro, pese a los cambios, y reducir el consumo de energía.

\footnotetext{
${ }^{40}$ Latova Fernández-Luna, J. [1999], p. 127.
} 
- Cumplimiento de la normativa legal vigente aplicable a un edificio de estas características.

- Mínimo impacto visual, por lo que toda la infraestructura necesaria para el suministro eléctrico se diseñará bajo esta condición.

- La operación segura del sistema que permita el funcionamiento ininterrumpido de los sistemas de emergencia, pese a averías o daños causados por operaciones internas o externas.

La disposición y el tipo de las luminarias elegidas para el diseño del monasterio cumplirán con la normativa europea vigente de iluminación de los espacios públicos, así como su cableado, canalización y cuadro eléctrico asociados cumplirán con lo regulado en la REBT y en la normativa europea aplicable.

Se deberán tener en cuenta los diferentes usos que tendrán cada una de las áreas del monasterio, aunque queremos conseguir que el resultado final sea el de un tipo de iluminación muy similar en todo el edificio, para intentar darle cierta uniformidad decorativa.

No hay que olvidar que un museo al exponer sus colecciones debe ofrecer un ambiente en el que el visitante pueda estudiar y disfrutar de esas piezas, contribuyendo igualmente a su conservación. De ahí, que la luz deba ser adecuada para permitir que el público pueda ver las obras con claridad, distinguir los detalles menores y las diferencias de color. Por ello, para el diseño de la iluminación de las salas en las que se exponen las piezas se han tenido en cuentan los siguientes factores:

- Niveles de iluminancia.

- Uniformidad

- Deslumbramiento desagradable y contraste visual.

- Brillo.

- Representación del color.

- Temperatura del color.

- Conservación.

- Radiación ultravioleta y exposición a rayos infrarrojos.

A continuación vamos a indicar qué tipo de iluminación situaremos en las distintas dependencias del Monasterio de San Jerónimo. 
En las salas de exposición permanente, presentan todas similares características en cuanto a su iluminación natural, éste penetra en las estancias de forma lateral, a través de vanos situados en uno de sus muros, en unas salas, por ejemplo en el Refectorio, los vanos tienen forma cuadrada, mientras que en otros, como en la Sacristía, son circulares, en ambos casos de reducidas dimensiones. Para evitar que estos vanos provoquen un efecto de contraluz a la hora de contemplar los objetos ubicados en estas salas, colocaremos cristales difusores que impidan la entrada de luz solar. Las salas también reciben luz natural, a través de las puertas que dan al claustro principal.
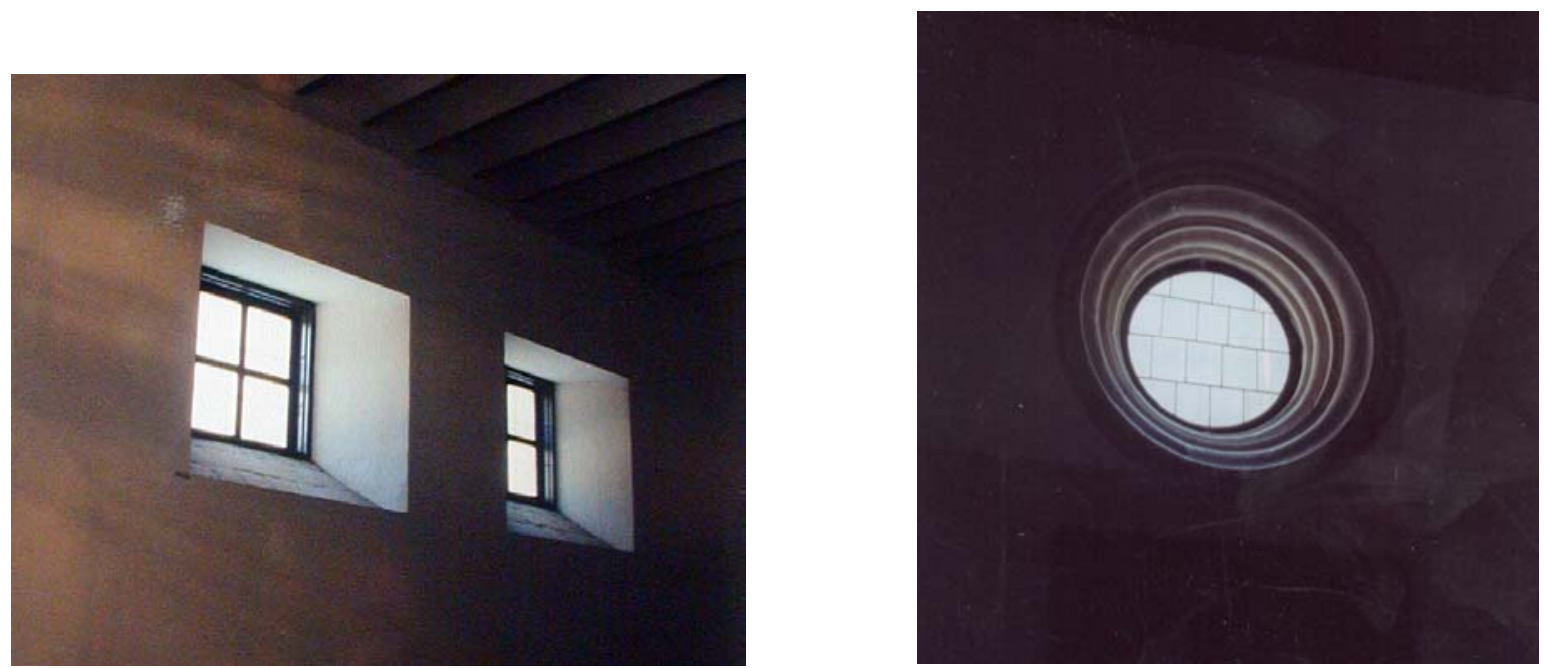

Ventanas del Monasterio de San Jerónimo.

Pero consideramos que esta luz no es suficiente, pues en la actualidad apenas permite ver las salas y las obras no se distinguen en absoluto. Por lo que instalaremos en ellas un nuevo sistema de iluminación. Ésta, será combinada, es decir, utilizaremos bañadores de pared para dar una luz ambiente a la sala y proyectores de acento para el realce lumínico de las obras de arte, estos se alimentarán desde carriles, con cableado trifásico, dispuestos en todas estas salas.

Para la instalación de cada uno de los proyectores se conectarán unas salidas de conexión, desde los registros primarios de cada estancia.

El zaguán es un espacio prácticamente cerrado, la única luz que tiene es la que penetra desde el exterior a través de la puerta de entrada. Por lo que instalaremos en todo el zaguán un alumbrado mediante bañadores de techo, que dará una iluminación indirecta a este espacio, pero en la zona de la taquilla, y en la tienda se reforzará este alumbrado indirecto mediante unas tiras lineales de fluorescentes, dando un acento lumínico a la taquilla e iluminando la zona de atención al público, y en la tienda resaltarán lumínicamente los productos a vender.

En la Biblioteca, situada en la segunda planta, se reforzará al alumbrado de la sala mediante downlights con lámparas halógenas de bajo voltaje que irán 
empotradas en el techo y lámparas de pie que pueden ubicarse en el lugar en el que sean requeridas.

En el claustro, situaremos luminarias empotradas en la pared, que darán una iluminación de ambiente al espacio, pero además esto se verá reforzado por un farol en cada esquina, utilizaremos los que existan en la actualidad, logrando así una unión entre funcionalidad y estética.

En la escalera, situaremos unas luminarias que iluminen la bóveda, de modo que resalten la decoración en relieve de yeserías.

Y por último, en la iglesia, donde nos encontramos ante el espacio más complicado de iluminar, tanto por sus dimensiones como por sus materiales. La luz natural que recibe la iglesia del Monasterio de San Jerónimo penetra a través de cuatro ventanas situadas en el muro del fondo del Coro y de las vidrieras ubicadas en la parte alta de los muros laterales.

El sistema que instalaremos será, en la iluminación general de la nave utilizaremos lámparas de descarga y fluorescentes, ya que presentan un gran rendimiento lumínico y un gran ahorro de energía. Además, distinguiremos dos tipos de iluminación diferentes:

- La iluminación ambiental, para la visita "turística" al Monasterio.

- La iluminación litúrgica, para las celebraciones litúrgicas.

La primera tendrá un alumbrado general de la nave, que resalte todos los elementos artísticos y arquitectónicos, permitiendo observar todos los detalles de las diferentes partes del templo.

En la segunda, la iluminación se centrará en los bancos donde se sitúan los fieles y en la Capilla Mayor, como detallamos a continuación.

En la iglesia nos encontramos con una de las piezas más importantes y significativas del Monasterio, el Retablo, ubicado tras el altar mayor. Además tendremos en cuenta que en ella se siguen celebrando algunas funciones litúrgicas, por lo que el presbiterio es el lugar donde se necesita una mayor cantidad de luz, por ello los gradientes de iluminación en los planos horizontal y vertical habrán de dirigirse a esta área. Intentaremos lograr que la mirada (que siempre se dirige a las zonas más iluminadas) se oriente de forma natural hacia esta zona.

La iluminación será mediante proyecciones laterales que formen cierto ángulo, (huyendo de una iluminación frontal y uniforme ya que tiende a aplanar la superficie) para realzar los volúmenes de las esculturas y relieves. 
Siguiendo las pautas que Rodríguez Lorite da para la iluminación de retablos ${ }^{41}$, armonizaremos dos sistemas de iluminación, uno de carácter general que alcanzará toda la superficie, con un valor de iluminancia bajo ya que la decoración de la obra es dorada, y un conjunto de localizaciones sobre los elementos iconográficos (esculturas) y litúrgicos (Sagrario).

Convendrá, por razones de uso, separar, los circuitos de modo que de disponga de un encendido general y otro específico, dirigido únicamente al motivo central del retablo y Sagrario.

En los aseos utilizaremos el sistema de tira lineal de fluorescentes, pero estos estarán empotrados en la parte inferior de los espejos, dando así un acento lumínico a los lavabos. Además se instalará un sistema de apagado y encendido del tipo temporizador para el ahorro de energía.

\section{- La iluminación de emergencia y señalización.}

Tanto el alumbrado de emergencia como el de señalización deberán funcionar de forma autónoma, durante tres horas, aunque la legislación sólo obliga a que la duración sea de una hora, creemos conveniente aumentarla para facilitar la evacuación tanto de personal como de piezas, en caso necesario.

Todo el alumbrado de señalización deberá indicar de manera permanente, la situación de las puertas, pasillos, escaleras, y salidas del edificio y deberá proporcionar en el eje de los pasos principales una iluminación mínima de luz.

Tanto el alumbrado de señalización como el de emergencia estarán constituidos por aparatos autónomos que en el momento en que se produzca un fallo del suministro entren en funcionamiento.

Todo ello según la normativa vigente de obligado cumplimiento.

\section{Dispositivos de la exposición.}

Los diferentes dispositivos que vamos a utilizar en la exposición, para facilitar la comprensión del Monasterio de San Jerónimo, son los siguientes:

- Los soportes. Los soportes tienen la función de ofrecer una buena sujeción, lo que permite realizar cambios dimensionales sin causar nuevas tensiones. A la hora de escoger el modelo de soporte tendremos en cuenta dos aspectos, por un lado el diseño, como punto principal de referencia tomaremos el centro de gravedad del objeto, sin dejar de tener en cuenta la finalidad original del objeto y por otro los materiales utilizados, que deben ser compatibles con el objeto y ser inertes, deberán servir de almohadillado y no tener bordes afilados ni ser fuente de abrasiones. Además el soporte no deberá perder estabilidad con el tiempo

${ }^{41}$ Rodríguez Lorite, M.A. [1999], p. 99-100. 
ni por las vibraciones, deberá amortiguar los movimientos siendo fácilmente accesible y fácil de quitar, y se utilizarán sistemas mecánicos para su colocación y no estarán unidos a los objetos de forma permanente.

Los clavos, ganchos y alambres utilizados para soporte deberán ser de acero inoxidable y estar cubiertos con tubos de nylon y polietileno.

- Pedestales. Los utilizaremos para situar sobre ellos las esculturas, de mediano y gran tamaño, con el objeto de realzarlas y aislarlas del suelo. Serán de madera y se construirán a medida, teniendo en cuenta el peso y las medidas del objeto que soportará. Constarán de cuatro caras laterales y una superior. Pintados de un color similar al de los muros (blancos), para no interferir en la visión de la pieza, ni de la sala en la que se encuentren ubicados.

- Las Vitrinas. Las utilizaremos para las esculturas que por su tamaño pueden ser susceptibles de robo o de otros posibles daños. Tendrán una medida aproximada de $60 \times 40 \mathrm{~cm}$. El diseño de las vitrinas que incorporemos al Monasterio, atenderá a determinadas normas de seguridad, ya que la conservación de los fondos en ellas expuestos, va a depender de ellas. Así, los materiales que usaremos en su construcción, madera y cristal, deben ser, en lo posible resistentes a los impactos, al fuego y a la humedad, y mostrarse químicamente estables y duraderos.

La estructura deberá estar muy bien equilibrada, pues deben aguantar vibraciones, sacudidas y golpes sin caer o derrumbarse. Los dispositivos de cierre no deben ser evidentes, para prevenir los intentos de robo o actos vandálicos.

No pueden tener resquicios, huecos o espacios abiertos por donde puedan introducirse elementos extraños como papeles o golosinas, extraerse los objetos del interior o hacer palanca para formar las cerraduras.

Tendremos también muy en cuenta el acceso al interior de las vitrinas, ya que éste deberá ser sencillo, cómodo y no interferir con los objetos, lo que facilitará la labor del técnico encargado de las colecciones.

La vitrina estará formada por tres partes diferenciadas, la base, la zona de exposición y un espacio donde albergar algún tipo de material higroscópico, capaz de regular la humedad relativa, así Art Sorb. exterior.

Las vitrinas carecerán de luz propia, las piezas será iluminadas desde el

Los cuatro flancos de la vitrina al ser transparentes permiten al visitante tener una visión global de la obra desde todos sus perfiles.

El mecanismo de apertura, uno de los cristales se corre lateralmente, para facilitar la labor del técnico contaremos con un instrumento tipo horquilla que sujete el cristal cuando se abra. 
- Los paneles. En la Portería, primera dependencia que se visitará en el Monasterio, ubicaremos una serie de paneles (8), aislados sobre la pared, en ellos habrá tanto información gráfica como de texto. Tendrán tres niveles de lectura, básica, medio y detallado. Toda la información estará tanto en castellano como en inglés, al igual que en sistema braille. A través de su información el visitante podrá conocer quién fundó el Monasterio y por qué, su historia, su vinculación con el urbanismo de la ciudad, etcétera. Todos los paneles, realizados en DM estarán situados sobre $110 \mathrm{~cm}$ del suelo, y las medidas serán 90 x $70 \mathrm{~cm}$.

- Módulo táctil. En la Portería ubicaremos un monitor, éste constará de una base de datos con información gráfica y de texto, sobre la historia del Monasterio de San Jerónimo de Granada, la Orden Jerónima en la historia y en la actualidad, etcétera. El monitor se encontrará a un metro del suelo, y tendrá cierta inclinación, con el objeto de que una persona en silla de ruedas pueda utilizarlo y visualizarlo sin problemas.

- Maquetas. Ubicaremos una maqueta del Monasterio, ésta podrá ser tocada, de modo que facilitará la comprensión de la arquitectura del monumento a los invidentes. Para su construcción utilizaremos, madera dura de algún árbol caducifolio, ya que este tipo presenta una mejor apariencia y mayor durabilidad.

- Reproducciones. Con el objeto de hacer más didáctica la exposición, ubicaremos en el claustro, en los huecos que hay en sus muros, unas reproducciones de pinturas con representaciones de la vida de San Jerónimo y de otros santos de la Orden, siguiendo la decoración original del claustro. Al encontrarse en el exterior los materiales serán, pintura acrílica (latex con pigmentos) sobre una tela de origen sintético con una preparación también sintética, de latex con una carga, por ejemplo blanco de España.

- El suelo. Mantendremos la solería de barro que hay en la actualidad en el Monasterio de San Jerónimo, al ser éste un material que actúa como un tampón, no refleja la luz y no resbala. En algunas zonas del Monasterio, así en la Sala de Profundis, quedan partes del suelo original, incluso aparece el año de 1543 en algunas de las olambrillas. Esta zona de solería la protegeremos para evitar su deterioro.

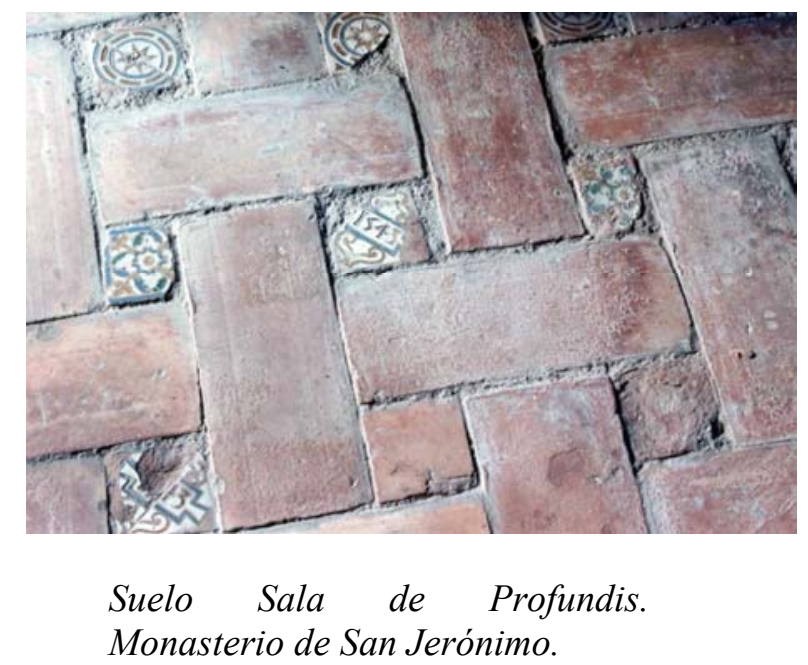


- Los techos. Mantendremos los techos, de madera, del Monasterio de San Jerónimo, ya que pretendemos respetar al máximo la arquitectura original. Monasterio.

- Las paredes. Conservaremos el color blanco de los muros de todo el

\section{El Almacén.}

"El Almacén o sala de reserva es un espacio fisico donde se instalan y ordenan las colecciones, se conservan y pueden ser utilizadas para diversos fines y actividades del museo como programas de exposiciones, de educación o investigación ${ }^{, 42}$. Es una de las áreas más importantes de un museo, pues de él se guardan las piezas de la colección que no están expuestas, pero no pueden almacenarse de cualquier manera ya que éstas deben de conservarse con unas condiciones de conservación y seguridad, igual o mejor que las piezas expuestas.

En cuanto a su ubicación, señalar que nos hubiera gustado situar el área de reserva de las colecciones en el propio edificio, pero debido a los problemas de espacio que éste presenta, hemos tenido que optar por instalarlo fuera. Estará ubicado en la Escuela de Latín y Música, en la parte del edificio que vamos a incorporar a nuestro proyecto, junto al Taller de restauración.

El acceso al almacén se realizará a través del Compás del Monasterio, de modo que el vehículo que transporte una pieza, pueda acceder hasta la misma puerta. Al igual que si hay que trasladar alguna pieza al Monasterio, el recorrido se hará dentro del propio recinto.

Los criterios, básicos, que seguiremos para el diseño del almacén del Monasterio Museo de San Jerónimo de Granada, son los siguientes ${ }^{43}$ :

- $\quad$ El espacio.

- Comunicación con otras áreas del Monasterio. Estará situado junto al taller de restauración.

- Formas y dimensiones. Las características espaciales de nuestro almacén se basan en el tipo de piezas (pintura, escultura y mobiliario) y en el tipo de sistema de almacenaje (peines, estantes y pallet). Lo construiremos previniendo necesidades futuras.

- Accesos. Estos se harán teniendo en cuenta que permitan facilidad de movimientos y que eviten maniobras difíciles.

\footnotetext{
${ }^{42}$ Hernández Hernández, F. [1998], p. 191.

${ }^{43}$ Nos hemos basado en las recomendaciones de Buces, J.A y Herráez, J.A. [1999], pp. 407-431
} 


\section{- La Colección.}

Los principales datos que necesitamos tener en cuenta a la hora de pensar en el almacén son acerca de la colección, así:

- Naturaleza de los materiales. La naturaleza de los materiales que constituyen las piezas de nuestra colección es determinante a la hora de tener en cuenta todas las normas a seguir para un correcto almacenaje. Así, nosotros tenemos óleo sobre lienzo y sobre tabla; marfil; madera estofada y policromada y mobiliario de madera.

- Técnica de ejecución. Dentro de cada objeto, hay que valorar la técnica artística empleada, el modo de ensamblaje, etcétera.

- Estado de conservación. Los objetos que presenten un estado de deterioro, al ser más sensibles a los factores de degradación, que los objetos que estén en buen estado de conservación, exigirán unas medidas más estrictas de conservación.

- Historial clínico. Conocer los tratamientos de conservación o restauración que ha sufrido una pieza son básicos para determinar unas condiciones óptimas de almacenamiento.

- Condiciones habituales de conservación. Es muy importante tener referencias de las condiciones de conservación, para poder definir unas condiciones óptimas y diseñar los mecanismos de control.

\section{- Disposición de los objetos.}

Teniendo en cuenta la naturaleza de nuestra colección, el sistema de almacenamiento que utilizaremos será el siguiente:

- Pintura, instalaremos un sistema de peines de rejillas metálicas, en los que se podrán ubicar los cuadros. Tomaremos la precaución de aislarlos del suelo (elevados a $10 \mathrm{~cm}$.), mantener su limpieza, protegerlos de la luz y revisarlos periódicamente.

- Escultura, los objetos de bulto redondo de gran peso y volumen los situaremos sobre pallet. Los aislaremos del suelo elevándolos $10 \mathrm{~cm}$. de éste y mantendremos la limpieza. En cuanto a la escultura de menor tamaño, se almacenará en estantes metálicos, protegidos por un material plástico transparente, permitiendo la ventilación.

- Mobiliario, estarán ubicados sobre pallet, de igual manera que las esculturas de gran peso y volumen. 

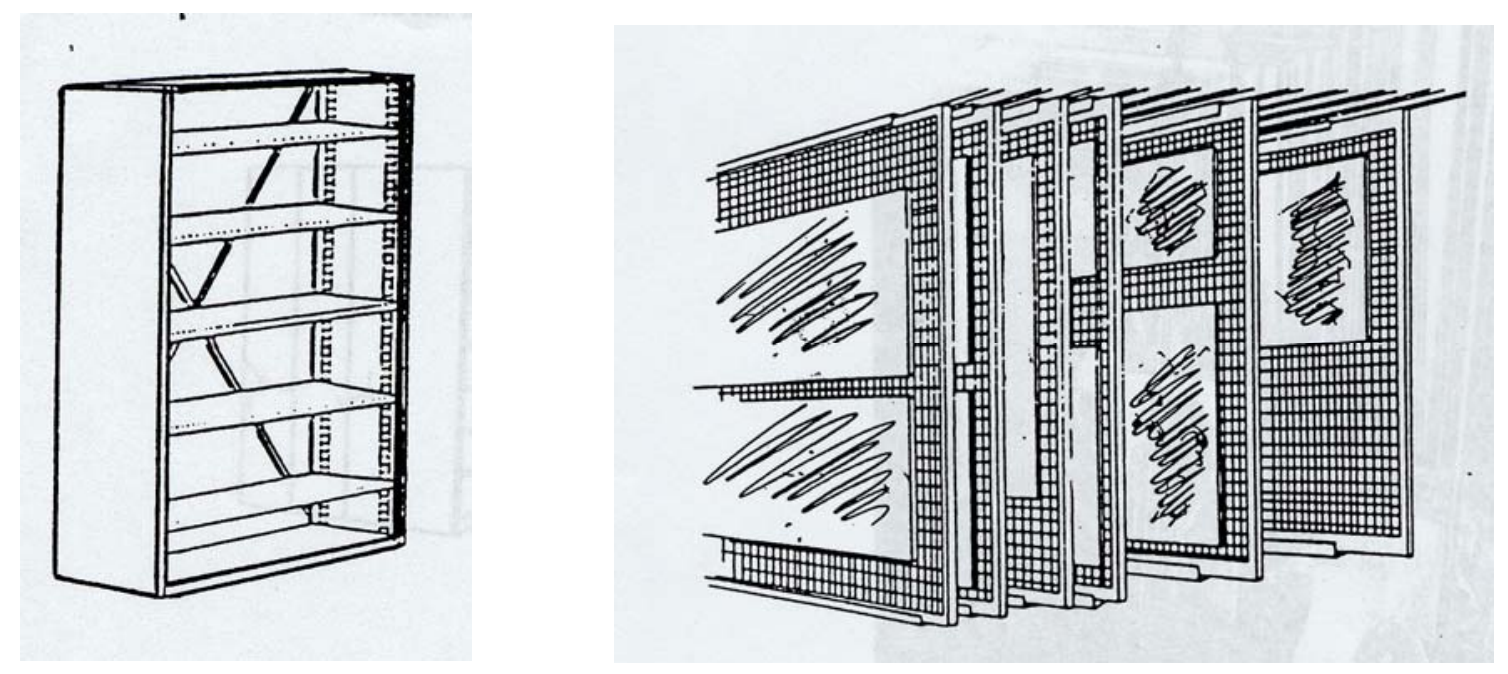

- Iluminación.

Debido a que esta sala tendrá un uso limitado a determinadas funciones, así la luz será necesaria para la limpieza, revisión de los objetos, movimiento de piezas, etcétera, prescindiremos de la luz natural, ya que ésa supone un factor de deterioro y perturbación de las condiciones ambientales.

Utilizaremos fuentes de luz cuya radiación infrarroja y ultravioleta sea la menor posible, teniendo en cuenta que no hay que seguir los condicionantes estéticos exigibles en las áreas de exposición.

Limitaremos el tiempo de encendido de la luz al necesario para llevar a cabo las distintas tareas, y tendremos mucho cuidado de que la luz no se quede conectada por descuido.

\section{- Factores microclimáticos.}

Los riesgos de deterioro de los objetos almacenados en el área de reserva se deben a niveles extremos o a cambios bruscos de humedad relativa y temperatura. De manera que procuraremos que en el almacén se tenga la máxima estabilidad térmica posible y que carezca de focos de humedad.

Controlaremos los datos de humedad relativa y temperatura mediante los sensores conectados al sistema automático e control, cuyo seguimiento realiza el conservador.

Las condiciones medioambientales que queremos mantener en el almacén, teniendo en cuenta los materiales, son:

- Humedad Relativa: 45\%-50\%.

- Temperatura: $15^{\circ}-20^{\circ}$. 


\section{- Manipulación, útiles y maquinaria.}

El momento de mayor peligro para los bienes culturales está en la fase de movimiento, ya que la manipulación conlleva los riesgos de vibración e impacto. Por ello, la manipulación deberá realizarse siempre por especialistas o estar supervisada por ellos, aplicando las siguientes normas ${ }^{44}$ :

- "La manipulación efectuada con las manos directamente requerirá del uso de guantes dobles; uno de látex, recubierto por otro de algodón. La utilización de guantes dobles evita que el sudor de las manos empape el guante de algodón, y éste dañe a la obra. Los guantes deben estar en todo momento en perfecto estado de limpieza.

- Se utilizarán cinchas de nylon cuando la peculiar textura, forma, peso, volumen o dificultad, así lo aconsejen.

- Los grandes pesos y volúmenes requerirán para su manipulación de mecanismos especiales".

- Prevención de riesgos. Seguridad.

- Robo y vandalismo. Para el área de reserva seguiremos las mismas normas de seguridad que para el resto del Monasterio, así utilizaremos cerramientos adecuados en muros, techos, suelos, ventanas y puertas, e instalaremos cerraduras de seguridad en puertas y ventanas para prevenir cualquier acto vandálico. También instalaremos mecanismos automáticos de detección con señales de alarma.

- Incendio. Contaremos con el mismo sistema de detección automática que en el Monasterio, la alarma estará conectada con las dependencias del personal de la institución y con el servicio de bomberos. Instalaremos, del mismo modo, sistemas de extinción manuales (extintores). Todos estos sistemas, junto con el eléctrico serán revisados periódicamente.

- Inundación. Es éste un peligro muy frecuente para los almacenes de museos, unas veces debido a catástrofes naturales y otras a fugas, roturas de las conducciones, etcétera, sobre todo si se producen por la noche. Para prevenirlo los peines, estantes y pallets nunca estarán situados directamente sobre el suelo, sino elevados a una altura mínima de 10 centímetros. Instalaremos un sistema automático de monitorización de las condiciones ambientales, dotados de una señal

\footnotetext{
${ }^{44}$ Buces, J.A. y Herráez, J.A. [1999], pp. 411-412.
} 
de alarma que detectará cualquier aumento brusco de humedad relativa. Siempre, después de una tormenta o tras un período de lluvias el almacén será revisado detenidamente.

- Terremoto. No debemos olvidar que Granada se encuentra situada en una zona sísmica, por lo que todos los bienes almacenados, igual que los expuestos, deberán estar bien anclados y correctamente situados.

- Plagas. Para prever posibles infestaciones, prescindiremos de la madera en la construcción del almacén, y las estructuras del edificio que sean de este material se tratarán adecuadamente con productos biocidas (insecticida y fungicida). Todos los cerramientos deberán tener la estanqueidad necesaria para impedir la entrada de organismos vivos, así aves o murciélagos, que pueden acumular mucha suciedad en rincones o agujeros que son focos de todo tipo de infestaciones. Las condiciones ambientales tienen relación directa con el control de plagas, de modo que evitaremos una humedad relativa alta, etcétera. En las inspecciones periódicas se tendrá especial atención a agujeros, rotos, manchas, excrementos, depósitos de serrín, escondrijos, etcétera.

- Contaminantes. Los cerramientos deberán tener la estanqueidad necesaria para impedir el paso de polvo y otras sustancias contaminantes. Los conductos que implican una recirculación del aire, así sistema de climatización y de ventilación, contarán con filtros adecuados para minimizar la entrada de polvo, contaminantes, etcétera. A la hora de construir el almacén tendremos en cuenta que los acabados interiores no desprendan sustancias volátiles que puedan reaccionar con las obras almacenadas. La limpieza se hará mediante aspiradores, la forma más óptima para eliminar el polvo y la suciedad. Se realizarán inspecciones periódicas de los objetos.

\section{Las áreas de servicio para el público general.}

Cada vez existe un mayor interés del público por los museos, los centros culturales y en general por la denominada cultura del ocio, etcétera. Y esta demanda supone más servicios y más exigencias.

serán:

Los espacios para el público general, dejando a un lado el área expositiva,

- Área de acogida, en el vestíbulo o zaguán, se encontrará la taquilla y el punto de información. 
- Los aseos estarán situados en el zaguán, de caballeros, de señoras (contarán con un espacio en el que poder cambiar los pañales a los niños pequeños), y para personas en sillas de ruedas. Cumplirán con la normativa europea vigente.

- Tienda, situada también en el zaguán.

- Área de descanso, durante todo el recorrido se ubicarán bancosasientos situados en puntos estratégicos para que las personas puedan descansar. El Compás del Monasterio, también cumplirá esta función.

No hemos contemplado la ubicación de una cafetería o de un restaurante, por las propias características espaciales y arquitectónicas de nuestro edificio. Además el Monasterio se encuentra ubicado en una zona muy céntrica de la ciudad, en la que se encuentran tan sólo a unos pasos numerosas cafeterías y restaurantes.

\section{Las áreas de servicio para el público especial.}

En la segunda planta del claustro principal, estará ubicada la Biblioteca del Monasterio, destinada a investigadores, contará con ejemplares de tres temáticas:

- Todo lo relacionado con el Monasterio de San Jerónimo.

- Todo lo relacionado con los bienes muebles que alberga el Monasterio.

- Todo lo relacionado con la Museografía, Museología y Patrimonio en general.

Pretendemos que la biblioteca del Monasterio Museo de San Jerónimo, sea un referente para la investigación de la Orden Jerónima, de sus monasterios, de sus bienes muebles, de sus monjes, etcétera.

\section{Las áreas de servicio internas.}

Las áreas de servicio internas, serán aquellas dependencias cuyo acceso tendrá un carácter restringido, ya que su uso exclusivo del personal de la institución, si bien podrán entrar otro tipo de personas pero siempre con una autorización.

En una de las alas de la segunda planta del claustro principal del Monasterio, estarán ubicados los despachos para el personal de la institución, es decir, en esta zona estarán ubicadas las siguientes áreas: 
- Área de Dirección.

- Área de Conservación e Investigación.

- Área de Difusión.

- Área de Administración.

Todos estos espacios contarán con el mobiliario y los instrumentos de trabajo necesarios. Estos espacios, al igual que el resto del edificio tendrán las condiciones de climatización, iluminación y seguridad determinadas, así:

\begin{tabular}{|l|l|l|}
\hline TEMPERATURA & HUMEDAD & OCUPACIÓN \\
\hline $20^{\circ}-25^{\circ}$ & Confort & $10 \mathrm{~m}^{2}$ por persona \\
\hline
\end{tabular}

El resto de espacios destinados a uso interno del personal de la institución son los siguientes:

- Vestuario, para el personal subalterno de la institución.

- Almacén para los útiles de limpieza y mantenimiento del edificio.

- Sala de máquinas.

- Sala para transformador de baja tensión.

- Sala para sistema de gestión de seguridad.

\begin{tabular}{|l|l|l|}
\hline TEMPERATURA & HUMEDAD & OCUPACIÓN \\
\hline $20^{\circ}-25^{\circ}$ & Confort & $5 \mathrm{~m}^{2}$ por persona \\
\hline
\end{tabular}

- El Taller de Restauración.

Esta zona de trabajo pertenece al Área de Conservación e Investigación, pero por las necesidades especiales que requiere este espacio, debido a su función, estará situado en otro lugar. El taller se ubicará en la Escuela de Latín y Música, junto al Almacén que ya comentamos. 
El objetivo primordial de este taller o laboratorio deberá ser la conservación y salvaguarda de todo el patrimonio que el Monasterio custodia. Además de este objetivo, en el taller podrán:

- Realizar estudios sobre el estado de conservación tanto de las piezas como del entorno que las alberga.

- Redactar informes sobre los conocimientos que se hayan obtenido al someter las piezas a estudio.

- Someter las piezas y edificio a acciones destinadas a su conservación preventiva.

- Actuar sobre las obras que así lo requieran: restaurando o conservando.

- Realizar un seguimiento exhaustivo del mantenimiento de las obras.

- Documentar y difundir todas sus actuaciones.

El taller para poder cumplir estos objetivos deberá contar con las siguientes características:

- Espacio suficiente, para separar todas las piezas, es decir, las tratadas de las no tratadas, las de distinta naturaleza material y cuya unión pudiese resultar nociva. Se tendrá sitio para trabajar con la facilitad y seguridad adecuada, contando con espacios independientes para la aplicación de barnices y vapores peligrosos, así como para la fumigación y otros tratamientos específicos.

- Accesibilidad, es fundamental que el taller cuente con puertas grandes que permitan el paso de obras de gran formato a esta sala, también deberá contar con palets, carros adecuados, etc. para facilitar el transporte de las piezas al taller, de ahí que éste situado en un espacio muy accesible, tanto desde las salas como desde el exterior.

- Iluminación, contará con iluminación tanto natural como artificial. La luz natural será lo más uniforme posible, evitando la luz directa del sol, por lo que situaremos en las ventanas unos filtros que eviten el paso de las radiaciones infrarrojas y ultravioletas que afectan a la obra, pero que dejan pasar la luz. En cuando a la artificial, es muy importante que se asemeje lo más posible a la luz natural, con el fin de que a la hora del tratamiento de la obra el restaurador pueda apreciar los colores sin ningún tipo de distorsión, ni vibración hacia ningún color, por lo que se usarán lámparas halógenas y fluorescentes. Para determinadas actuaciones el restaurador contará con lámparas articuladas de incidencia individual. 
- Ventilación, es muy importante, debido al uso de disolventes y otros productos que poseen gases tóxicos, tanto para el restaurador como para las obras. Ésta podrá ser natural, siempre que no afecte a la estabilidad de la temperatura y de la humedad o que permita el acceso al taller de sustancias perjudiciales para las obras, o artificial, es decir, campas de extracción, que resultan indispensables durante el uso de determinados productos e instrumentos o tratamientos.

- Climatización estable, tanto de la temperatura como de la humedad relativa.

- Agua abundante, con sistemas de desmineralización y/o destilación.

- Desagües apropiados y tratamiento de aguas residuales producidas por el taller, así se podrá componer por una fosa de aneación, fosa de decantación y un filtro biológico.

- Electricidad, con potencia adecuada, tanto alterna como continua, para los distintos aparatos.

- Seguridad, en esta zona se situarán los mismos elementos de seguridad que se instalarán en el resto del edificio y que ya comentamos al hablar de la seguridad, teniendo en cuenta que la peligrosidad que conlleva trabajar con determinados productos, altamente inflamables, es decir, protectores internos con detectores volumétricos, infrarrojos, y de temperatura, ..., circuito cerrado de televisión, control de accesos, detección automática y manual de incendios, sistemas de extinción de incendios, tanto automática como manual

El equipo básico y los instrumentos con los que contará el taller, serán:

- Sistema de calentamiento:

- Estufas.

- Pistolas de aire caliente, Leister.

- Lámparas con rayos infrarrojos.

- Sistemas de desecación:

- Cámara de desecación.

- Cámara de vacío.

- Baños en disolventes.

- Sistema de visibilidad:

- Lupas o Binoculares con soporte.

- Microscopio.

- Cámara fotográfica. 
- Recipientes para:

- Soluciones y Disolventes.

- Productos sólidos.

- Otros.

Además, teniendo en cuenta que la casi totalidad de las obras que se tratarán serán lienzos, tablas y tallas de madera el taller podrá contar con los siguientes instrumentos:

- Agua de Soldar.

- Espátula caliente.

- Plancha.

- Mesa de Baja Presión.

- Bolsa de Vacío (envoltura de vacío).

- Radiador Infrarrojo, Varilla Calorífera Infrarroja.

- Microscopio.

- Balanza electrónica para pesar productos usados, en procesos de restauración.

- Etcétera.

\section{Especificaciones de señalética.}

En toda exposición existe una historia que contar, y la señalética que vamos a emplear nos ayudará a hacerlo. Elaboraremos una estrategia de comunicación que facilitará al visitante la comprensión de lo que queremos contarle, darle la clave de nuestro discurso expositivo, es decir, interpretar la información para que la exposición no resulte confusa.

Una información que permitirá el acceso a los contenidos del Monasterio, desde cuatro niveles de orientación, geográfico, psicológico, intelectual y conceptual.

Para transmitir esta información nos serviremos del texto escrito, la forma más tradicional y usual de ofrecer información en las exposiciones. Los numerosos estudios que se vienen ocupando de los textos consideran en ellos una serie de aspectos significativos en relación con la comunicación:

- Los diferentes contenidos;

- Las características de legibilidad o confort visual de los textos;

- Las condiciones de atracción, atención y comprensión de los textos;

- Su situación en relación con el contenido previsto;

- Las interrelaciones entre soportes y contenidos informáticos. 
Dentro de la señalética que situaremos en el Monasterio podemos establecer diferentes tipos que se corresponden con diferentes usos, así orientativos, explicativos y de identificación, por lo tanto contaremos con señales que:

- Orienten en el exterior del Monasterio;

- Ubican al visitante;

- Identifiquen cada dependencia;

- Identifiquen cada obra.

El diseño que emplearemos en la elaboración de las distintas señales pretendemos que sea ante todo simple y claro, sin olvidar que la historia contada a través de los textos debe estar en total armonía con el diseño expositivo.

En cuanto a las condiciones de legibilidad tipográfica en la producción de los textos vamos a seguir las siguientes recomendaciones generales, dadas por Ángela García Blanco ${ }^{45}$ :

- Que exista contraste entre el color de fondo y el del texto, teniendo en cuenta que el mayor contraste se produce entre el blanco y el negro, éste será el que utilizaremos.

- El tamaño de los caracteres deberá ser tal, teniendo en cuenta distancia y destinatario, que por encima del cual no se mejore la lectura y por debajo no se pueda leer. En concreto:

- Cartelas: 24 puntos.

- Textos de conjunto: entre 30 y 36 puntos.

- Textos principales: entre 48 y 60 puntos.

- En cuanto al dibujo de los caracteres y la tipografía, tendremos en cuenta que se leen mejor las minúsculas que las mayúsculas, y mejor en tipo romano que en bastardilla. Este tipo lo podremos emplear en textos cortos o expresiones especiales. La mayúscula la usaremos para los títulos o subtítulos.

- La longitud de las líneas será tal que el ojo no se pierda, si son demasiado largas, o que éste continuamente volviendo si son demasiado cortas. Creemos que una longitud óptima sería una línea que comprenda entre diez o doce palabras, es decir, entre sesenta y setenta caracteres.

- El espaciado de líneas deberá ser armonioso de modo que no resulten textos demasiado blancos o demasiado negros.

\footnotetext{
${ }^{45}$ García Blanco, A. [199], p. 140-141.
} 
- Los párrafos no serán demasiado largos y densos, con el fin de que no necesiten mucho tiempo para ser leídos.

- Utilizaremos frases cortas y simples, teniendo en cuenta que el largo medio de una frase eficaz para adultos es más o menos de quince palabras.

- También, cuidaremos la estructura de las frases, la lógica de la sintaxis. Colocando, por ejemplo, las palabras esenciales al principio de la frase porque son las que se retienen mejor.

A continuación describiremos los modelos propuestos para la señalética del Monasterio de San Jerónimo de Granada.

\section{- Las señales del exterior del Monasterio.}

Hemos podido comprobar que sólo existen dos señales orientativas, que nos indican hacia donde ir para poder visitar el Monasterio, una ésta ubicada junto al Hospital de San Juan de Dios y la otra junto a las oficinas del periódico Ideal. Creemos que su ubicación no es la más idónea pues están demasiado cerca del monumento, debería haber otras señales antes, por ejemplo, localizadas en los cruces de las calles:

- Esquina Avenida de la Constitución con la calle San Juan de Dios.

- Avenida de la Constitución, en el giro hacia la calle Severo Ochoa.

- Doctor Severo Ochoa, en el giro hacia la calle Rector López Argüeta.

Nos pondremos en contacto con el Ayuntamiento de la ciudad para ubicar estas nuevas señales, ya que las consideramos muy importantes, pues si un visitante no puede llegar hasta el Monasterio nosotros no podemos ofrecerle nada.

Respecto a las señales que identifican el Monasterio, responden al modelo que el Ayuntamiento de Granada ha establecido para todos los edificios singulares, son dos, una está ubicada en el muro, a la izquierda de la puerta por la que se accede al Monasterio, en la calle Rector López Argüeta y la otra se encuentra sobre un mástil junto a la otra puerta de acceso. 


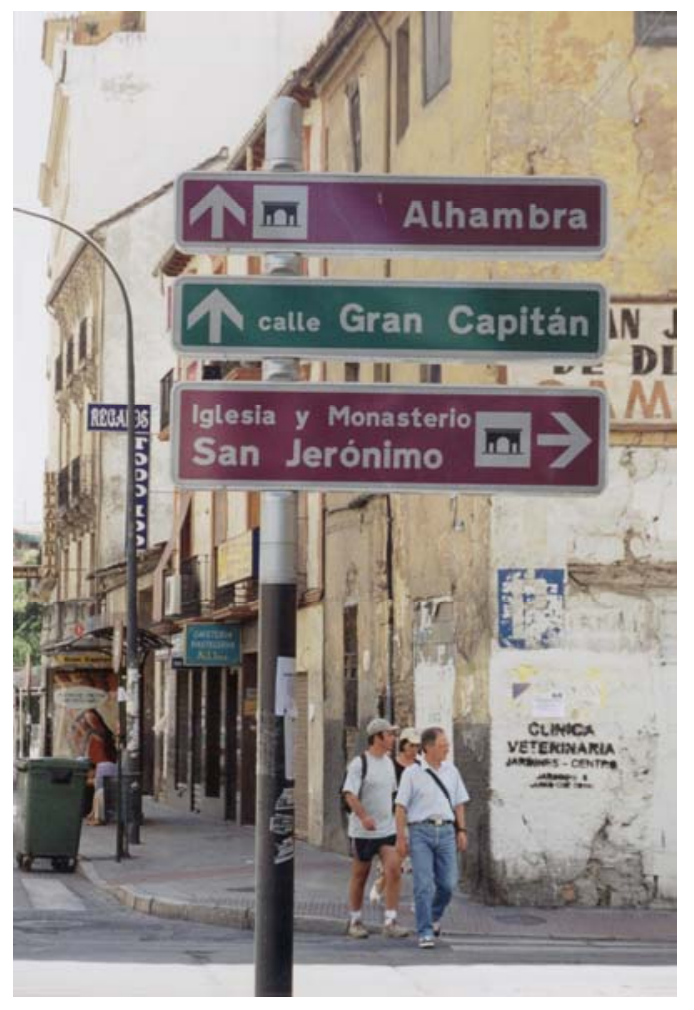

Cruce San Juan de Dios con Rector López Argüeta

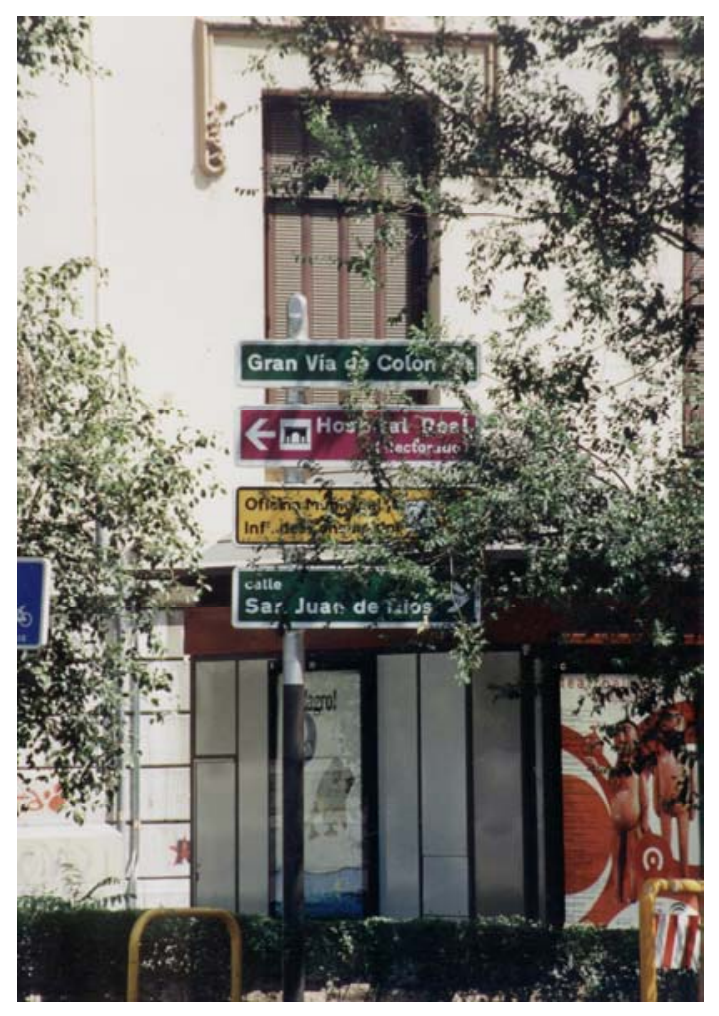

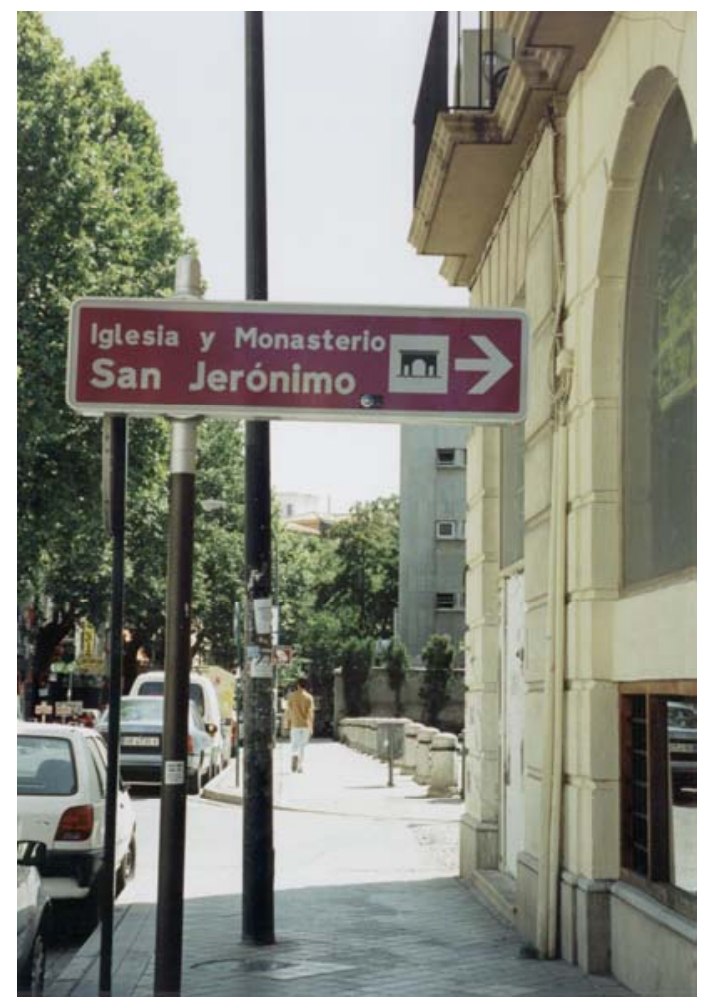

Junto a las oficinas de Ideal Gran Capitán

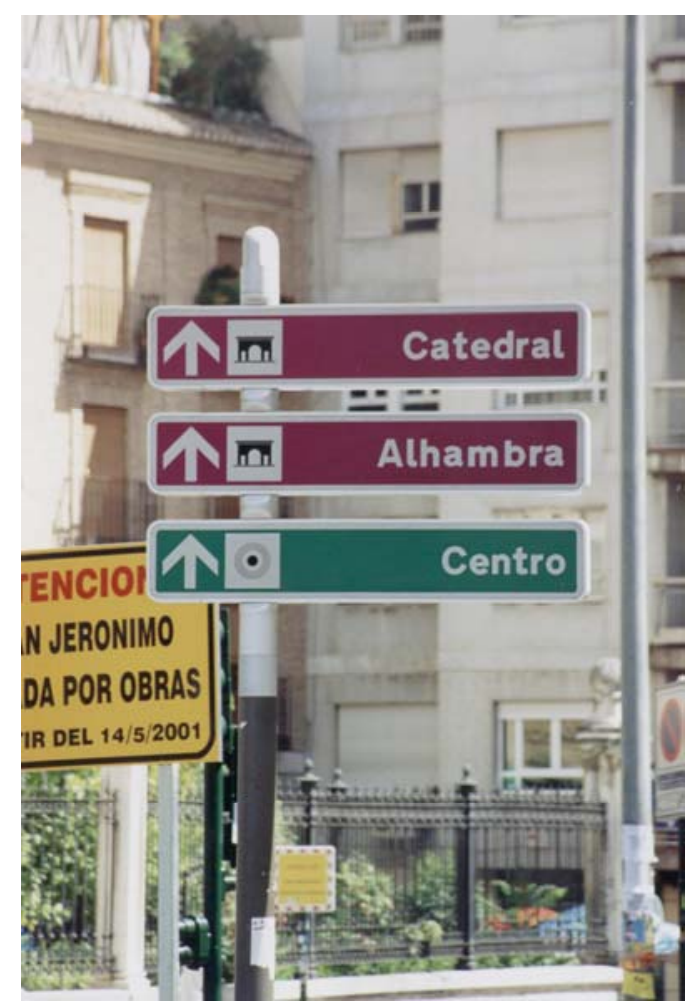

Señales orientativas en los cruces de Gran Via y San Juan de Dios. 


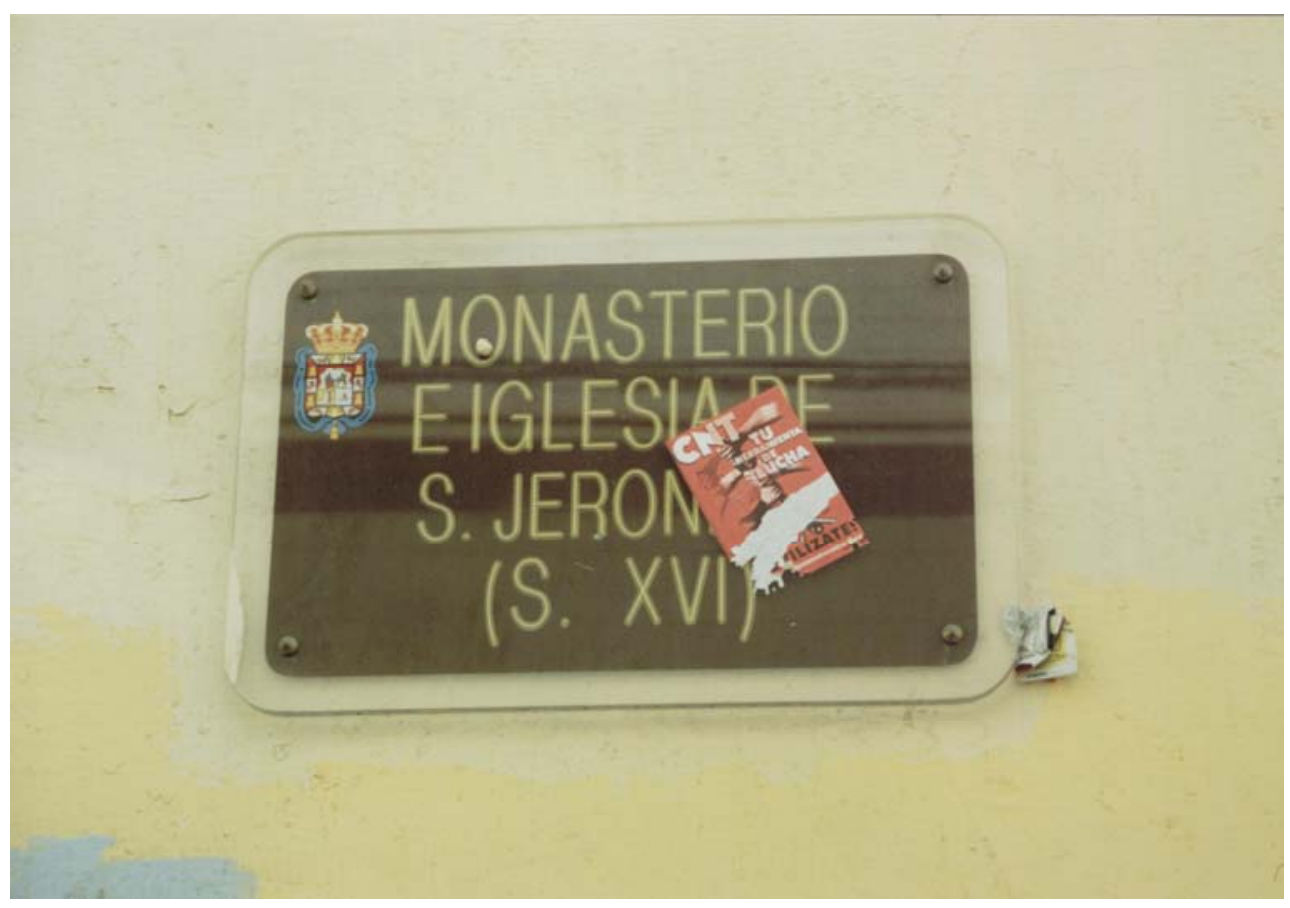

Señal, acceso desde Rector López Argüeta.

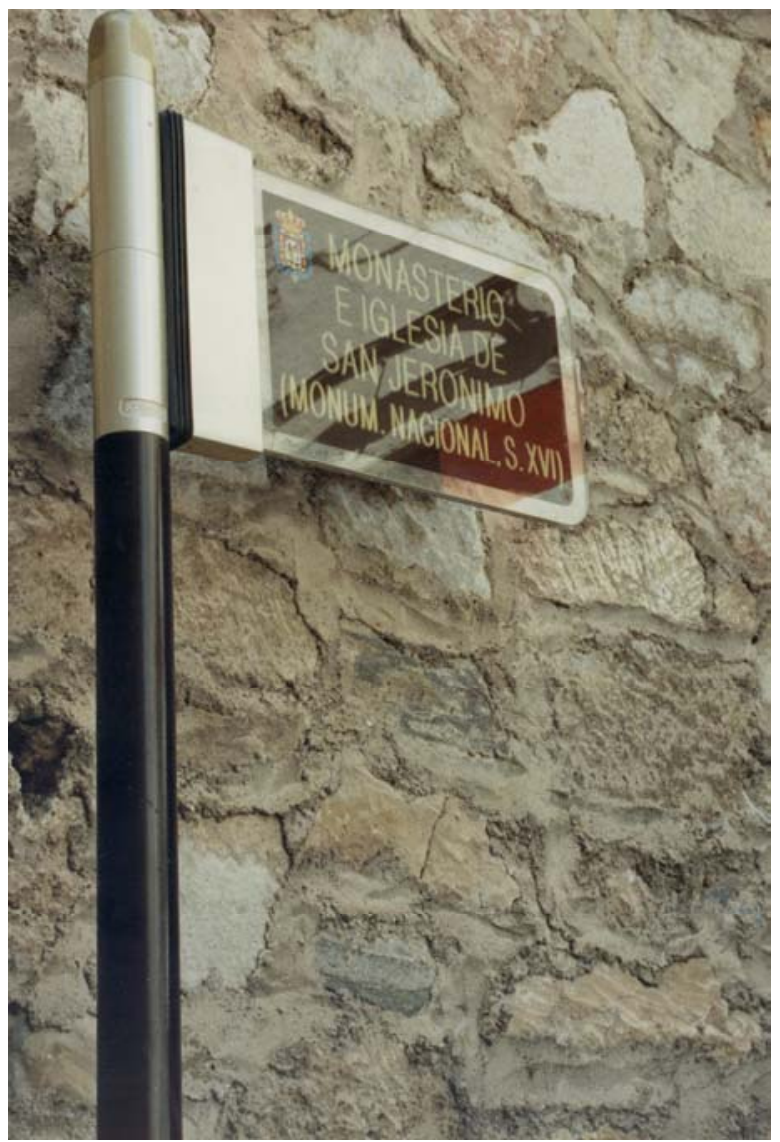

Señal, acceso desde Gran Capitán. 


\section{- Las señales del interior del Monasterio.}

- Panel orientativo del edificio. Situaremos un panel en el zaguán, a la derecha, en la pared, de la puerta de entrada a la portería del Monasterio. En éste panel se incluirá un plano del edificio, indicando dónde se encuentra cada sala, deberá ser comprensible para cualquier tipo de público y nos dará una imagen global del edificio. Será el mismo que aparezca en el tríptico informativo.

El panel será de metacrilato transparente y la leyenda en color negro, ya que la pared sobre la que va colocado es de color blanco.

- Título de las Salas. Identificaremos cada sala con un título, éste será el nombre de la dependencia, haciendo referencia a su función original. Será de metacrilato transparente y el nombre en color negro. Lo situaremos a la derecha de la puerta.

- Panel explicativo. Dentro de la sala pondremos un texto más largo, en el que contaremos la función de la dependencia. El texto irá acompañado de un grabado en el que se represente alguna escena que tuviera lugar en esa sala. Este texto es muy importante ya que interpreta gran parte de la exposición, su contenido estará estructurado con gran cuidado debido a su carácter explicativo.

- Cartelas. Junto a cada objeto situaremos una etiqueta o cartela, es decir, un soporte de pequeñas dimensiones en el que aparecerá escrito un texto corto que dará una información básica del objeto, así: nombre del objeto, autor, escuela, año y materiales.

No obstante, en algunos casos concretos se podrán ofrecer detalles específicos más amplios sobre determinadas piezas de la colección.

Así, el Retablo de la Capilla Mayor, debido a sus características tendrá una cartela con un diseño y un contenido muy distinto al resto, más parecida a los textos explicativos de cada una de las salas, pero un módulo de pie, vertical, que pueda eliminarse a la hora de las celebraciones litúrgicas. Consistirá en un diagrama del Retablo en el que se identificarán mediante números todos los temas iconográficos que aparecen.

El mayor problema que nos encontramos, es la ubicación de esta información, ya que no podemos colocar nada sobre la pared, al estar todos los muros cubiertos por pinturas, ni colocar nada que perturbe la contemplación de esta magnífica iglesia. Tras comprobar in situ cual sería el lugar más idóneo hemos optado por colocar este panel informativo en la capilla mayor, en el lateral del lado de la Epístola.

Por último señalar que la información escrita lo estará en braille, castellano y en inglés, ya que muchos de los visitantes serán extranjeros. Nos gustaría incluir otras lenguas pero esto acarrearía la necesidad de mayor espacio, lo que no es 
posible si queremos que las señales pasen lo más desapercibidas posible, por lo que optaremos sólo por el inglés. Jerónimo:

Ejemplos de algunas señales que vamos a situar en el Monasterio de San

- Título de la Sala:

\section{Refectorio}

- Cartela identificativa:

La Coronación de la Virgen Pedro Atanasio Bocanegra $1685-1714$

Escuela granadina Óleo sobre lienzo 
- Texto explicativo de sala:

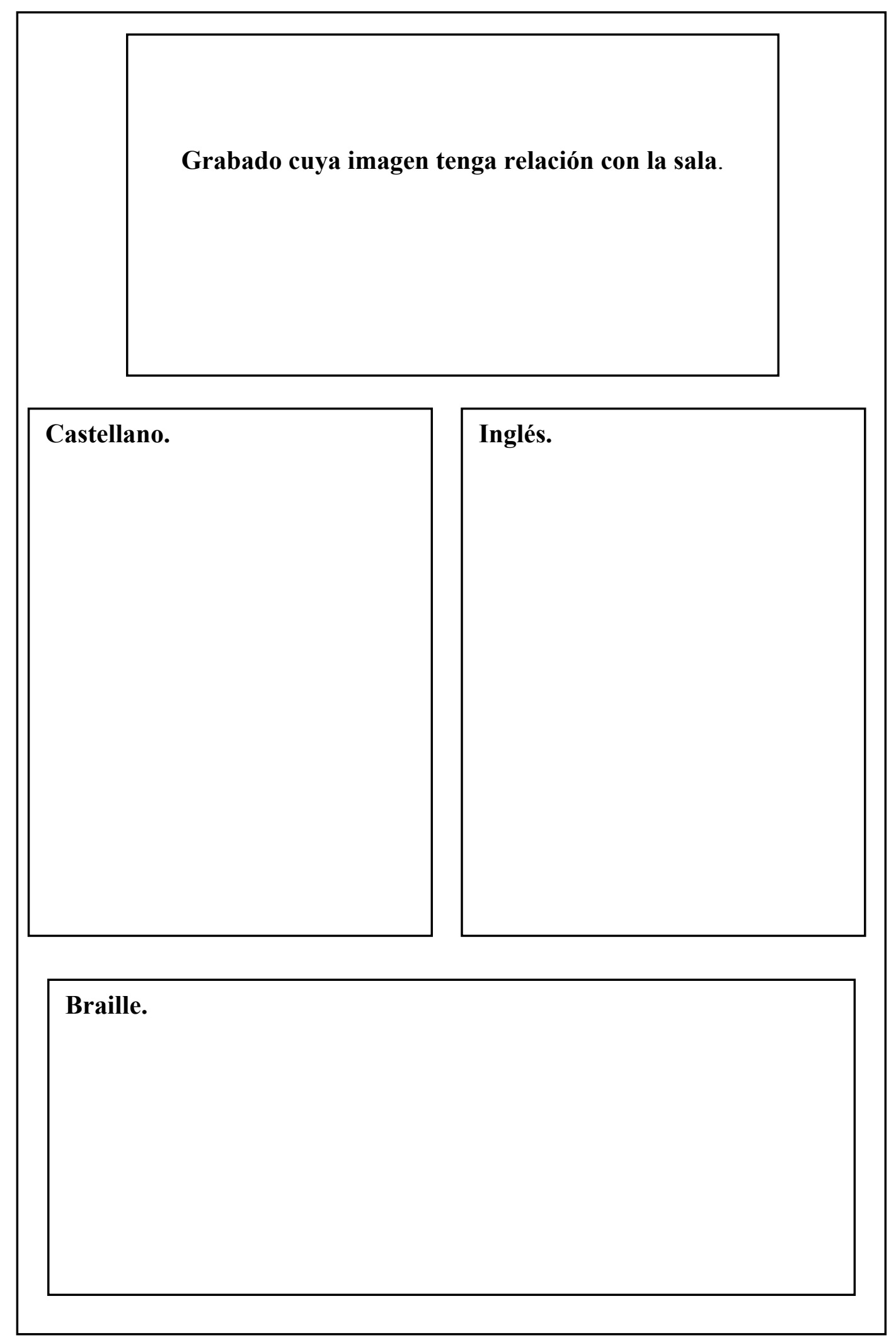


- Retablo Panel informativo. En él se incluirán los temas iconográficos representados ${ }^{46}$, así:
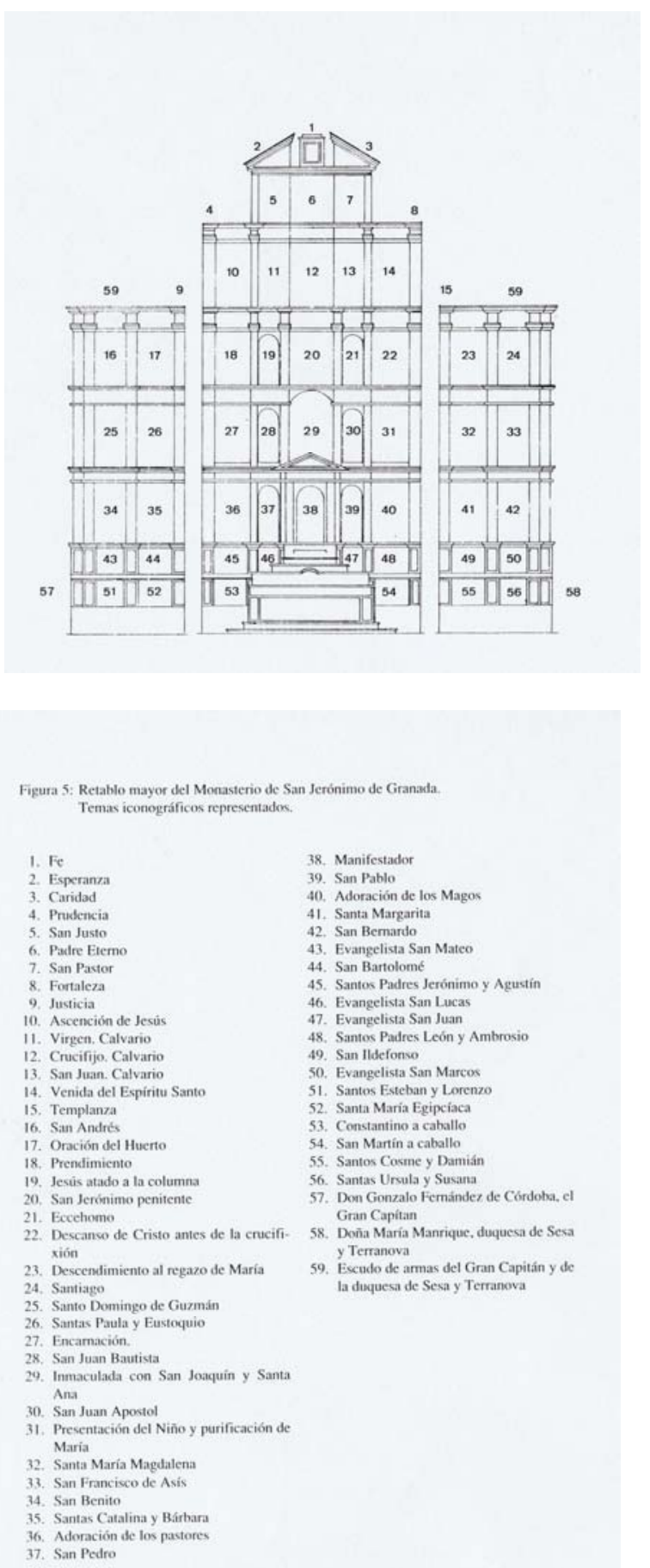

${ }^{46}$ Martínez Medina, F.J. [1989], fig. 5. 
- Señales de evacuación. Encargaremos el diseño de un modelo especial de señalética, que respete la estética del Monasterio. Podría ser similar a la diseñada por Julio Juste y realizada por Antonio Sorroche, para el Museo de la Casa de los Tiros de Granada.
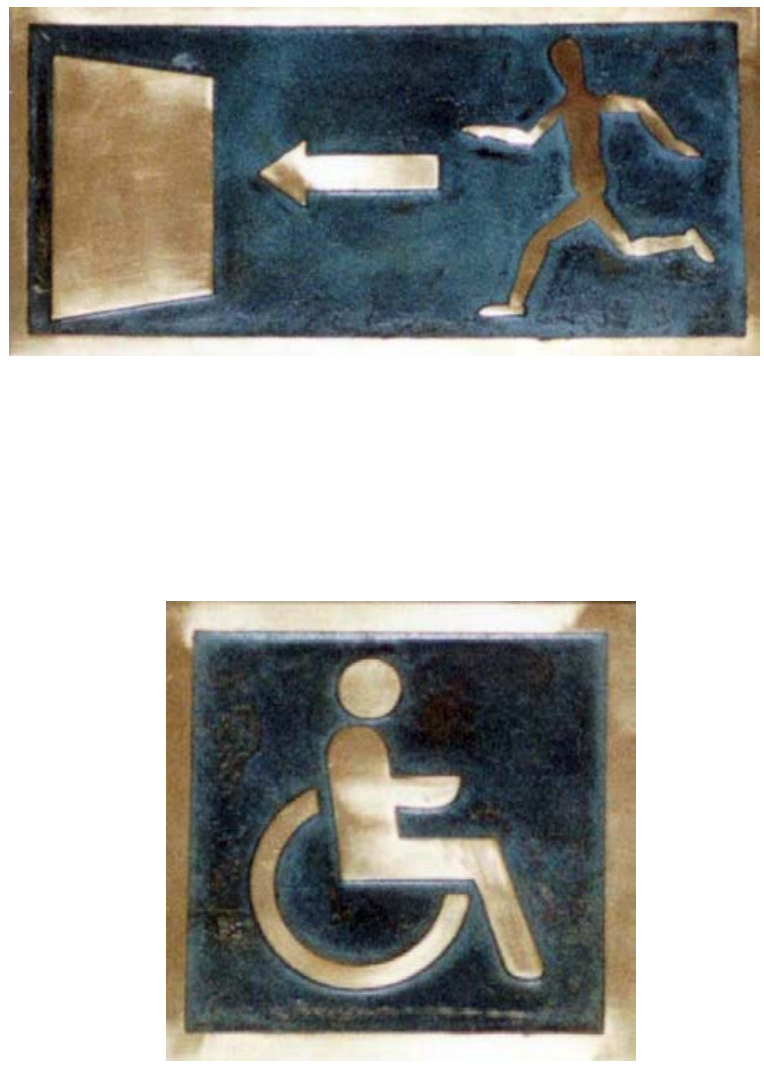

Ejemplos de señalización del Museo Casa de los Tiros. 
IV. EL CONTENIDO. 


\section{EL CONTENIDO.}

\section{La colección fundacional.}

Como ya comentamos al principio, el contenido que queremos mostrar al público que visite el Monasterio de San Jerónimo, es por un lado, el propio edificio, y por otro, los bienes muebles que éste alberga, al haber hablado ya del edificio como contenedor, ahora nos centraremos exclusivamente en el patrimonio mueble.

El hecho de que la Orden Jerónima se dedicará plenamente al aspecto espiritual y no al político provocó que reyes y nobles depositarán el cuidado de su espíritu en esta Orden, protegiéndolos desde el comienzo de su fundación. También se fueron acercando a la devoción de la Orden burgueses, lo que ayudó mucho al enriquecimiento de los monasterios jerónimos.

Al principio, los monjes de la Orden Jerónima no eran hombres de letras, pero a mediados del siglo XV existen entre ellos varios miembros capacitados en las diversas Artes, surgiendo las bibliotecas, además a partir del siglo XVI empiezan a surgir los Colegios, en los que se enseñan las Ciencias Humanísticas, así como las Universidades.

Como hemos dicho, la realeza, la nobleza y la burguesía bien acomodada acudirán en demanda de consejos espirituales, impresionados por la vida ascética de los monjes jerónimos, a cambio de esta ayuda espiritual se convertían en donantes de tierras y de objetos artísticos, llegando muchos de estos bienes a la Orden por legado testamentario de sus benefactores.

Por ello, en parte, el gusto que impere en el patrimonio de los monasterios jerónimos será el de los donantes de las obras. Con la llegada del Renacimiento y sobre todo del Barroco, los jerónimos abrirán su sensibilidad cultural a las tendencias artísticas que imperaban en la época, facilitando el enriquecimiento de retablos, pinturas, esculturas y objetos litúrgicos, contando además con la presencia de los artistas más insignes del momento, quienes se enorgullecían de que sus obras estuvieran presentes en edificios de tanta trascendencia.

"Artistas locales o de dimensión nacional e internacional encontraron en los claustros, en las iglesias, sacristías o salas capitulares el marco más ensalzador de sus creaciones artísticas, "Adorad al Señor con sagrada pompa", dice el salmista y, para conseguirlo, los artistas unieron sus inspiradas creaciones a la austera majestuosidad de las celebraciones religiosas de los jerónimos". ${ }^{47}$

Además de estos artistas habría que contar con los propios monjes, que se dedicaban a realizar los trabajos que precisaban los monasterios, así miniaturas, bordados de ropas litúrgicas, forja, etc. El prior del monasterio presentaba al

${ }^{47}$ Mateo Gómez, I., Prados García, J.M. y López Yarto Elizalde, A. [1999], p.75. 
Capítulo, sin su aprobación no se podía llevar a cabo la obra, las necesidades que tenían de bienes artísticos muebles. Una vez aprobado, el prior era el responsable directo de la obra y debía informar a los visitadores de la provincia sobre la forma, funcionalidad y coste de la obra. Si los visitadores observaban alguna anormalidad, informaban a los Generales, que en caso de pleito o necesidad podían enviar inspectores. En cuanto a pintura y escultura, todo lo que pudiera tener algo de "impuro", por ser contrario a las buenas costumbres y sencillez de la Orden, se desaprobaba.

El desapego "oficial" que los monjes jerónimos tenían ante la abundancia de sus bienes materiales, causó que los reyes acudieran a ellos de forma asidua para solicitar ayuda económica. Esta situación se puede ver reflejada en un refrán del siglo XVII: "Mesa de francisco, coro de bernardo, hábito de agustino, bolsa de jerónimo, púlpito de dominico" 48 .

La preocupación que tenían los jerónimos por lograr el esplendor del culto, les llevó a hacer de sus monasterios importantes museos, en los que sus retablos se dedicaban a la vida de Cristo o de la Virgen, aunque siempre había alguno lateral o en el claustro, dedicado a San Jerónimo. Desde el siglo XV, bien al temple, al fresco o al óleo, había series de la vida del Santo e historias de la Orden decorando los claustros, salas capitulares o sacristías. También custodiaban importantes objetos litúrgicos en plata, oro, piedras preciosas y ropas litúrgicas que llegaron a ellos por testamento o donación y ya a partir del siglo XVII por encargo de la propia Orden.

El Monasterio de Granada fue un claro ejemplo de lo que acabamos de decir, había sido enriquecido con numerosas obras de arte, hasta que lo perdió todo, primero durante la invasión francesa y después con la Desamortización de Mendizábal en el año 1835.

A los pocos días de haber sido ocupada la ciudad en 1810, unos comisionados de José Miguel de Asanza, comisario regio nombrado por los franceses, recorrieron el monasterio para realizar un inventario, como podemos deducir de sus palabras, la situación era desoladora:

"Nos constituímos dentro del Monasterio después de haver vencido alguna dificultad que ocurrió con los Zentinelas y tropas que estaban apoderadas de todo lo interior del Conbento y haviendo registrado muy despacio las Celdas de los dos Claustros altos las hallamos quebrantadas todas las Puertas a la violencia, rotas las Cerradras, las mas con tablas despedazadas y dentro los muebles de sillas, papeleras rotas y robadas, trastos, papeles y Libros por medio, con evidencia de su total transtorno y robo que en ellas se havía hecho. Después bajamos a la iglesia y con dolor reconocimos que los Sagrarios estaban quebrantados, sin haber en ellos ni en sus Altares Copón, ni cosa sagrada, no existía ninguna Lámpara de Plata de las muchas que havía, la Imagen de Nuestra Señora del buen Suceso y el Niño, sin las coronas de Plata y todos los demás Altares y relicarios atropellados. En la

\footnotetext{
${ }^{48}$ Mateo Gómez, I., Prados García, J.M. y López Yarto Elizalde, A. [1999], p.76.
} 
Sacristia, cuyas puertas estaban también quebrantadas y Francas, nos hallamos todos los Hornamentos de casullas, Capas, Dalmáticas, Estolas, Manípulos, paños de Cáliz, Volsas de Corporales y demás de esta clase, rodando por el suelo, las más de ellas quitados los galones y despedazadas por muchas partes. Los cajones donde se custodiaban, quebrantados y habiertos. La taca donde se custodiaban los cálices, quebrantada y sin plata alguna dentro [...].

[Es] indispensable providenciar el auxilio de quatro zentinelas militares, que impidan el que la demás tropa se interne dentro del conbento, a lo menos en las piezas donde existen los enseres, pues estando yo arreglando los efectos para el inventario, handan por medio de nosotros los soldados escogiendo y tomando lo que les parece". ${ }^{4}$

Debieron ser muchas las obras de San Jerónimo ya que los Reyes Católicos y los primeros señores de Granada le cedieron muchos bienes. Así, Doña María Manrique, duquesa de Sessa, legó todos sus retablos, imágenes, ornamentos, tapices, banderas y joyas, entre las que destacaba una cruz de oro con un Lignum Crucis, además de otras muy ricas para hacer una custodia.

Isabel Mateo, José Ma Prados y Amelia López-Yarto, en su estudio sobre el arte de la Orden Jerónima comentan algunos Libros de Actas Capitulares que se encuentran en el Archivo Histórico Nacional. En la mayoría se recogen de manera preferente las fundaciones de capellanías para sepulturas y en otras se refiere sólo a la petición de enterramiento en el monasterio, muchas conllevan algún dato artístico por lo que nos podemos hacer una idea de lo que existía en el Monasterio de San Jerónimo, así:

- Con fecha 19 de agosto de 1528, Doña María de Peñalosa solicitaba al convento que se diese para su enterramiento y sus descendientes "el refitorio viejo que solía ser y que se pasase a él le capitulo y que ella se ocuparia de adornar de ornamentos y retablo con lo demás y que se le dixesen cuatro misas cada semana con ciertas fiestas para lo cual daba dote suficiente en limosnas" $\left(\mathrm{f}^{\mathrm{0}} 11 \mathrm{v}\right)$.

- El 21 de octubre de 1530, Antonio de Vallejo demandaba para su enterramiento y de su mujer y sucesores "la capilla que es del claustro media entre la capilla del Alcaylde Medrano y otra que tiene agora la casa en que está la puerta donde entran del claustro a la iglesia que agora tenemos que es del lienzo donde está el retablo del licenciado Puebla..." (fo 12v)

Este documento trae además una lista de capillas otorgadas, de las que vamos a incluir aquellas en que consta un ornamento o aderezo concreto, y que son del siglo XVI:

\footnotetext{
49 "Diligencias e Inbentario gral. de la Platta Muebles y demás effectos que se encontaron en el Monasterio de S. Jerónimo" Documento citado por Gallego y Burín, pp. 71-72.
} 
- Enterramiento de Domingo Velastegui, escribano de la Audiencia Real que dio 234.384 maravedís, gastándose 57.000 maravedís en un retablo que "está en la estación y rincón donde está enterrado el licenciado Puebla, abogado de esta audiencia y él hizo un retablo muy bueno que está en la dicha estación y dio un ornamento de terciopelo negro a la casa".

- Doña María de Pañalosa costea el reparo de los ornamentos e hizo un retablo en el capítulo.

- El capitán Cepeda de Ayala quería también una capilla y se compromete a labrar la reja y el retablo así como los ornamentos necesarios.

A partir del folio 142 , ya en el año 1607 , se señalan nuevas capellanías que, con las anteriores, da idea de la abundante retablística renacentista y barroca localizada en las capillas del claustro y otros lugares, así:

- El 18 de agosto de 1610 Francisco de Trillo adereza su capilla funeraria (dentro de la iglesia) con retablo, reja y otros ornamentos $\left(\mathrm{f}^{\mathrm{o}} 152 \mathrm{v}\right)$.

- En 1618 Pedro Martínez por precio de 100 ducados adquiere una capilla para su entierro con la condición que se adorne de retablo y reja y ornamentos $\left(\mathrm{f}^{\mathrm{o}}\right.$ $179 \mathrm{v})$.

Otras notas que aparecen en el Libro de Actas Capitulares referentes a reformas y obras menores son:

- El 26 de noviembre de 1595 se propone que la capilla del Santísimo se incorpore a la Sacristía "para servicio de ella...y que en reparos de los cajones de la sacristía y otras cosas y en incorporar la dicha capilla gastase hasta quinientos ducados" (fo 92v).

- Con fecha de 6 de mayo de 1598 el prior fray Gabriel de San Jerónimo dice que de su dinero quería hacer "una pila grande de piedra blanca de la sierra de Filabres con su pedestal blanco para el claustro grande que costaría como doscientos ducados" (f 105$)$.

- El 21 de julio 1600 se recoge que "los retablos de la capilla mayor que es de San Gregorio y de nuestro padre San Jerónimo [laterales del crucero] se acabasen ansí lo de la madera...como lo de la pintura y doramiento" $\left(\mathrm{f}^{\mathrm{o}} 112 \mathrm{v}\right)$.

- En julio de 1600 se señala la conveniencia de hacer una lámpara de plata "que costase quinientos ducados poco más o menos" para la capilla mayor. Se alude también a la venta de ropas de culto viejas para hacer otras nuevas.

- El 2 de julio de 1606 se propone hacer unos candeleros de plata, pues "tanta necesidad habia de ellos". 
- El 27 de mayo de 1604 las noticias son referentes al testamento de la Duquesa de Sesa, doña María Sarmiento, que "se enterró en la capilla mayor. Abierto el testamento deja al monasterio un juro de 140.000 maravedís de renta perpetua...un portapaz de oro, un cáliz de plata, un cofre de corporales y paños para la sacristía, una cruz pequeña de cristal, una imagen de Nuestra Señora que ahora está en un marco en la sacristía y es la imagen de oro y seda, un dosel pequeño de terciopelo morado, un pedazo de tela y una alfombra" (f $\left.\mathrm{f}^{\circ} 136 \mathrm{v}\right)$.

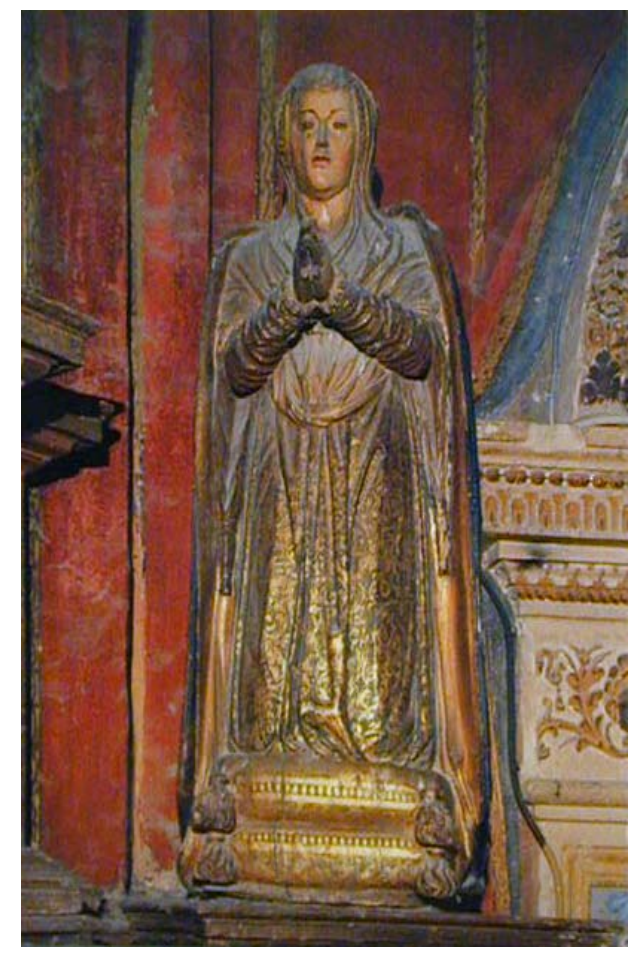

Dña. María de Manrique, duquesa de Sesa.

Monasterio de San Jerónimo.

También señalan estos mismos autores el Libro Becerro del Archivo Histórico Nacional (Clero, Libro 3692), en éste aparece la solicitud y concesión de la capilla funeraria de doña María Manrique requiriendo que se pudiera enterrar en la capilla mayor a su esposo, el Gran Capitán, pormenorizando cómo había de ir el sepulcro en cuanto a ornamentación, dando de dote para ello 50.000 maravedís de renta anuales el 27 de marzo de 1523. Así: para la capilla mayor, "el aderezo de capilla de plata el mejor que tengo que es la cruz, vinajeras e portapaz y la cruz de oro del Lignum Crucis, y que de ciertas joyas de oro que yo tengo y que fueron de mis hijas María y Beatriz se haga una custodia en que e ponga el Lignum Crucis y otra reliquia que tengo de San Jerónimo”; dona ricos paños para ropas de culto; "que todos los retablos principales que tengo se den a nuestra capilla"; las imágenes siguientes para los altares pequeños de la capilla: "una imagen de la Piedad, el retablo de los Reyes, el de San Miguel, el de la Resurrección, el que tiene una imagen de la Nuestra Señora con su Hijo en brazos, las tablas pintadas de negro con letras de oro, otra imagen grande de Nápoles questa en el oratorio 
do dicen misa, otra imagen pequeña de cuando Nuestra Señora fue huyendo a Egipto para que la pongan encima de estas imágenes en algún altar chiquito, el Jesús, la imagen de San Francisco, las otras imágenes que se repartan entre mis herederos".

Han localizado también, en el mismo Archivo, las Actas Capitulares desde el año 1777 hasta el 1808 (Libro 3727), en el que se recogen datos interesantes sobre el contenido artístico, así podemos destacar:

- En 1777 se ayuda con limosnas a las monjas de Santa Paula para concluir el retablo de San Clemente.

- En 1779 "un devoto estaba dispuesto a solar y poner de piedra la capilla y frontal de Nuestra Señora de la Concepción y de la capilla de las Gracias y asimismo para su mayor culto y que se pudiera decir misa en su altar si venían en que se abriese el arco que correspondía a la capilla de San Judas y custodiándolo con una reja".

- En 1792, reunida la comunidad el prior dio a conocer una carta de doña María de Heyrame, vecina de Jerez de la Frontera, en la que a través de fray Juan de Granada, "donaba una cruz que consta de catorce esmeraldas con su botón y unas jitanillas de las mismas, que cada una tiene ocho, para que siempre las tenga puestas dicha Señora [de los Afligidos]...no se pueda prestar, deshacer, ni cambiar dicha alhaja...y al final de sus días le canten una misa de réquiem con vigilia por sólo una vez". "El prior dijo abriese un libro con todas las alhajas donadas y el nombre de los donantes".

\section{La colección dispersa.}

No todas las piezas se perdieron, pues "la desamortización fue responsable del surgimiento en nuestro país de instituciones culturales periféricas que, con mayor o menor fortuna, quedaron convertidas en almacenes del patrimonio artístico incautado a las órdenes religiosas" ${ }^{~}$, , las Comisiones de Monumentos fueron las encargadas de la recogida de las piezas, cuyo conjunto será el germen para la creación de un museo en la ciudad, el actual Museo de Bellas Artes de Granada. Hasta su ubicación actual, en el palacio de Carlos V, fueron varios los lugares que se buscaron para albergar las obras inventariadas, así el convento del Ángel Custodio, el convento dominico de Santa Cruz la Real, la casa número 11 de la calle Arandas o la Casa de Castril, e incluso se propuso al principio el Monasterio de la Cartuja.

En todo este largo y arduo proceso las piezas sufrieron diversos avatares, así el 14 de febrero de 1839 se descubrió el robo de nueve lienzos en el convento

\footnotetext{
${ }^{50}$ Villafranca Jiménez, M.M. [1998], p. 43.
} 
dominico, éste hecho fue descrito por José de Castro y Orozco el 20 de marzo de 1839, uno de los lienzos procedía de San Jerónimo:

" $\mathrm{N}^{\mathrm{o}}$ 2.-El Salvador de un apostolado de escuela flamenca de altura más de dos varas y vara y media de ancho. Era procedente del Monasterio de San Jerónimo" ${ }^{51}$.

Señalamos a continuación las piezas que pertenecían al Monasterio de San Jerónimo y que hoy son propiedad del Museo de Bellas Artes de Granada:

- Trozo decorativo de un retablo, con medallón con busto, jinetes, mascarones, calaveras y cartela, Anónimo.

- El cuadro Virgen en la casa de Nazaret, de Pedro de Raxis.

- La talla de madera San José, de José Risueño.

- El esmalte denominado El Tríptico del Gran Capitán, de Penicaud.

- El grupo escultórico del Santo Entierro de Jacobo Florentino.

- La Circuncisión del Señor de Arnao de Vergara.

- Virgen con el Niño de Diego de Siloé.

- Santo Tomás, Anónimo.

- Santiago, Anónimo.

- San Simón, Anónimo.

- San Felipe Apóstol, Anónimo.

- San Matías, Anónimo.

- San Jerónimo, Anónimo.

- San Pedro, Anónimo.

- Santiago el Menor, Anónimo.

- San Juan, Anónimo.

- San Judas Tadeo, Anónimo.

- San Andrés, Anónimo.

${ }^{51}$ Archivo de la Real Academia de Bellas Artes de San Fernando. Legajo 2-48/1, documento citado por Villafranca Jiménez, M.M. [1998], p.49. 


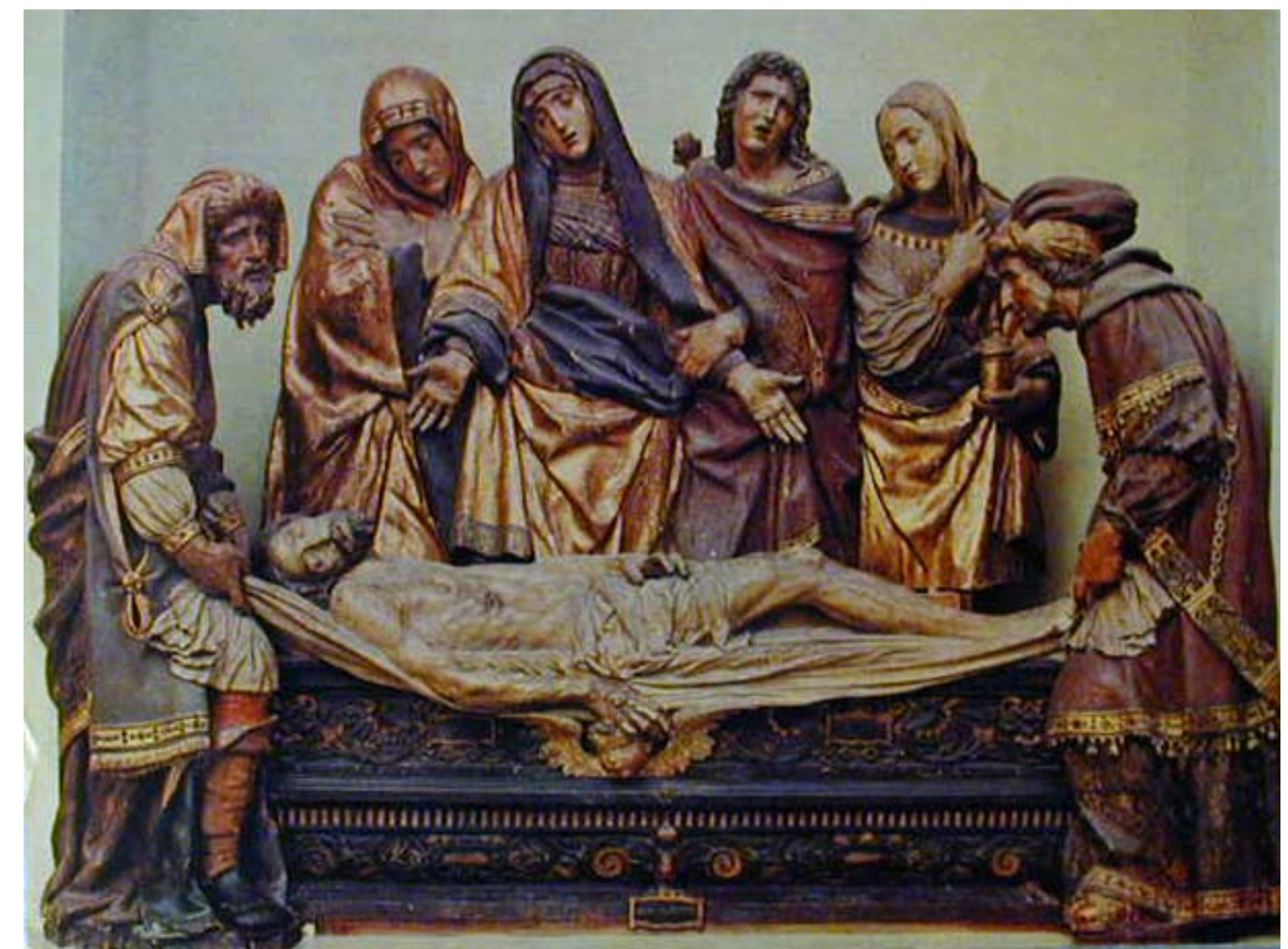

Santo Entierro, Jacobo Florentino. Museo de Bellas Artes de Granada.

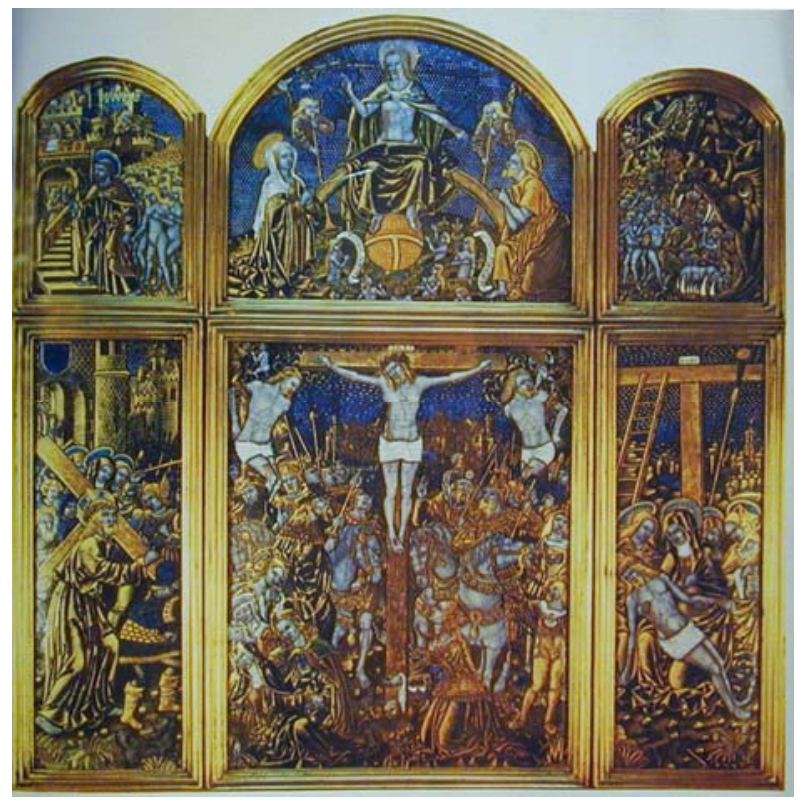

Esmalte del Gran Capitán, Penicaud. Museo de Bellas Artes de Granada. 
- San Andrés, Anónimo.

- San Mateo, Anónimo.

- Virgen con el Niño, Anónimo.

- San Bartolomé, Anónimo.

- Inmaculada, Anónimo.

- Ilmo. Sr. D. Cristóbal de Castilla y Zamora, Anónimo.

- Don Esteban de la Fuente y Alanis, Escuela madrileña.

- Ilmo. D. Andrés de Rueda y Rico, copia.

- Ilmo. Sr. D. Jerónimo del Valle y Ledesma, copia.

- Ilmo. Sr. D. José Pérez Valiente Pretel de Granada, Joaquín Inza.

También pertenecen al Museo de Bellas Artes de Granada otras dos piezas que se encuentran depositadas en otros dos museos, así:

- 18 colegiales del Seminario de San Jerónimo, obra anónima que fue depositada en el Museo Casa de los Tiros de Granada el 3 de Noviembre de 19129. de Toledo.

- Adoración de los Reyes de Arnao de Vergara en el Museo de Santa Cruz

Es posible que existan otras piezas en el Museo de Bellas Artes de Granada que procedan del Monasterio, pues en el Catálogo de este Museo, aparecen muchas en las que se indica que proceden de conventos, sin especificar a cual. Por falta de tiempo no hemos podido investigar los libros de registro del Museo de Bellas Artes de Granada con detenimiento, pero dejamos abierta la posibilidad de hacerlo en un futuro, ya que el tema nos parece muy interesante.

\section{La colección actual.}

Actualmente las obras que se encuentran en el Monasterio de San Jerónimo de Granada, proceden de diversos lugares.

La mayor parte de ellas del Convento de Santa Paula, que como ya comentamos anteriormente, era el Convento en él que la comunidad de monjas jerónimas residía, y que cuando se trasladaron a San Jerónimo lo hicieron junto con todas sus obras. 
Pero también, nos encontramos con obras que proceden del Carmen de los Mártires, propiedad de Sor Cristina de la Cruz Arteaga quien lo había heredado de su padre, el Duque del Infantado, quien a su vez lo había comprado a Huberto Meersmans de Smet. Éste último había mandado construir un edificio junto al Carmen de los Mártires para albergar su inmensa colección, el Museo de los Mártires, que permaneció abierto durante casi veinte años. Sor Cristina vendió la mayor parte de las obras, destinando los ingresos obtenidos al acondicionamiento y ayuda de los distintos conventos de la Orden Jerónima, las piezas que no vendió, de temática religiosa, fueron depositadas en el convento de Santa Paula en Sevilla y en San Jerónimo de Granada ${ }^{52}$.

Otras obras se encuentran depositadas en el Monasterio, así Pérez Sánchez al estudiar la Obra de Juan de Sevilla ${ }^{53}$ hace referencia a los lienzos de la Historia de San Juan de Dios, propiedad de la Hermandad del Refugio.

Gallego y Burín señala en su Guía de Granada ${ }^{54}$ que en la clausura del Monasterio se conservan numerosas obras de arte, indicando, además, muchas veces la procedencia de éstas:

- un cuadro grande de la Virgen Niña, con San Joaquín y Santa Ana de Pedro Atanasio Bocanegra;

- cuatro paisajes con motivos evangélicos de José de Cieza;

- dos cuadros con cabezas de mártires, firmados por Sebastián Valdés del Llano, procedentes de los Mártires;

- un lienzo del Sacrificio de Abraham, de Risueño;

- un San Jerónimo, de Marinus;

- dos cuadros, de la Virgen lactando al Niño y San Antonio, de estampa canesca, ambos procedentes del Monasterio de Santa Paula;

- un busto de la Virgen de Belén, de Risueño, procedente de la casa del Duque del Infantado; Galdeano;

- una cabeza de San Juan Bautista, procedente de la colección Lázaro

- un retablo enmarcado por columnas salomónicas; Mártires;

- un cuadro de la Sagrada Familia de Sánchez Cotán, procedente de los

\footnotetext{
${ }^{52}$ Gutiérrez García, A.M. y Hermoso Romero, I. [2000], p. 292.

${ }^{53}$ Pérez Sánchez, A. E. [1982], p.385.

${ }^{54}$ Gallego y Burín, A. [1996], p.294.
} 
- un retablo del siglo XVI, procedente de la iglesia de San Matías, presidido por una imagen del siglo XVI, de la Virgen y el Niño, procedente del Hospital de la Caridad y del Refugio;

- una figura en barro cocido, de San Jerónimo penitente, firmada por Alonso Cano en 1649;

- un lienzo de la Purísima, de Teodoro Ardemans, procedente de Santa Paula;

- un lienzo de Cristo y Pedro, de Rueda, también de Santa Paula.

Actualmente y según el Inventario de los Bienes Muebles de la Iglesia Católica, realizado en el Monasterio de San Jerónimo de Granada por el Instituto Andaluz del Patrimonio Histórico (I.A.P.H) ${ }^{55}$, la colección artística del Monasterio estaría constituida por los siguientes bienes:

(Los datos que se facilitan en este Inventario siguen el orden de Título; Tipología; Autor; Cronología; Estilo; Escuela; Materiales; Técnica; Medidas.)

- Virgen de las Angustias. Pintura de caballete; Anónimo español; Barroco; Escuela granadina; 1700-1714; Pigmento, Aceite; Pintura al óleo; 2,27 x 1,54 m.

- San José. Escultura; Anónimo español;1650-1699; Barroco; Escuela granadina; Pan, Oro, Pigmentos; Estofado, Policromado y Tallado; 1,38 x 0,59 x $0,42 \mathrm{~m}$.

- San Cristóbal.; Pintura de caballete; Bocanegra, Pedro Atanasio, Guevara; 1650-1699; Barroco; Escuela granadina; Pigmentos, Aceite; Pintura al óleo; $3,22 \times 1,79 \mathrm{~m}$.

- Cristo atado a la columna; Escultura de bulto redondo; Anónimo español; 1585-1599; Manierismo; Escuela granadina; Pan. Oro, Pigmento Pan. Oro, Pigmento; Estofado, Policromado y Tallado; 2,23 x 0,98 m.

- San Pedro penitente. Esculturas de bulto redondo; Anónimo español; 1585-1599; Manierismo; Escuela granadina; Pan, Oro y Pigmentos; Estofado, Policromado y Tallado; 1,37 x 1,02 x 0,23.

- El Calvario. Pinturas de caballete; Anónimo español; 1600-1699; Barroco; Escuela española; Pigmentos y Aceite; Pintura al óleo; 1,48 x 1,04 m

\footnotetext{
${ }^{55}$ Agradecemos al Departamento de Documentación del I.A.P.H. el habernos facilitado una copia de este Inventario para incluirla en el Proyecto de musealización del Monasterio de San Jerónimo de Granada.
} 
- Marco; Calvario. Marcos; Anónimo español; 1600-1699; Barroco; Escuela granadina; Pan. Oro y Pigmentos; Policromado, Tallado y Dorado; 2 x $1,52 \mathrm{~m}$.

- La Virgen entrega el rosario a Santo Domingo. Pinturas de caballete; Anónimo español; 1600-1699; Barroco; Escuela española; Pigmentos y Aceite; Pintura al óleo; 1,22 x 1,21 m.

- Marco; Virgen entregando el rosario a Santo Domingo. Marcos; Anónimo español; 1600-1699; Barroco; Escuela granadina; Pan. Oro, Pigmentos; Policromado, Tallado, dorado; $1,66 \times 1,70 \times 0,57 \mathrm{~m}$.

- Virgen de Guadalupe. Pinturas de caballete; Anónimo español; 16001699; Barroco; Escuela granadina; Pigmento. Aceite; Pintura al óleo; 2,05 x 1,43 $\mathrm{m}$.

- San Pío V. Escultura de bulto redondo; Anónimo español; 1600-1699; Barroco; Escuela granadina; Pan. Oro, Pigmento; Estofado Policromado Tallado; $1,90 \times 0,66 \times 0,52 \mathrm{~m}$.

- Cristo atado a la columna. Pinturas de caballete; Bocanegra, Pedro Atanasio; 1650-1676; Barroco; Escuela granadina; Pigmento. Aceite; Pintura al óleo; 1,25 x 1,25 m.

- Santa. Pinturas de caballete; Anónimo español; 1600-1699; Barroco; Escuela española; Pigmento. Aceite; Pintura al óleo; 1,35 x 1 m.

- Virgen Dolorosa. Esculturas de vestir; Risueño, José, Seguidor de; 16501699; Barroco; Escuela granadina; Pan. Oro, Pigmento; Estofado Policromado Tallado; $1,58 \times 1 \times 0,70 \mathrm{~m}$.

- Cristo yacente. Escultura de bulto redondo; Mora, Seguidor de los; $1595-$ 1599; Manierismo; Escuela granadina; Pan. Oro, Pigmento; Estofado Policromado, Tallado; $1,89 \times 0,29 \times 0,54 \mathrm{~m}$

- Sillón. Mobiliario, Sillones frailero; Anónimo español; 1600-1699; Barroco; Escuela española; Damasco; Técnica de ebanistería; 1,06 x 0,68 x 0,60 m.

- Retablo de los Fundadores. Retablos; Anónimo español; 1795-1795; Barroco; Escuela española; Piedra; Estucado; 5,20 x 6,70 x $1 \mathrm{~m}$.

- Retablo de los Fundadores. Retablos; Florentino, Jacobo, llamado "El Indaco", Siloé, Diego de; 1500-1599; Renacimiento; Escuela española; Piedra; Estucado, Policromado, Dorado; 7,55 x 7 x 0,60 m.

- Lansquenete; Retablo de los Fundadores. Escultura de bulto redondo; Anónimo español; 1500-1599; Renacimiento; Escuela española; Piedra; Estucado, Policromado; $1,82 \times 0,50 \times 0,45 \mathrm{~m}$. 
- Escudo; Retablo de los Fundadores. Escudo heráldico; Siloé, Diego de; 1500-1599; Renacimiento; Escuela española; Piedra; Estucado, Policromado dorado; $3,36 \times 1,93 \mathrm{~m}$.

- Lansquenete; Retablo de los Fundadores. Esculturas de bulto redondo; Anónimo español; 1500-1599; Renacimiento; Escuela española; Piedra; Estucado, Policromado, Dorado; 1,78 x 0,58 x 0,45 m.

- Fe; Retablo de los Fundadores. Esculturas de bulto redondo; Anónimo español; 1500-1599; Renacimiento; Escuela española; Piedra; Estucado, Policromado; $1,21 \times 1,25 \times 0,40 \mathrm{~m}$.

- Figura masculina; Retablo de los Fundadores. Esculturas de bulto redondo; Anónimo español; 1500-1500; Renacimiento; Escuela española; Piedra; Estucado, Policromado; 80 × 87 × $25 \mathrm{~cm}$.

- La Esperanza; Retablo de los Fundadores. Esculturas de bulto redondo; Anónimo español; 1500-1599; Renacimiento; Escuela española; Piedra; Estucado, Policromado; $1,25 \times 1,08 \times 0,40 \mathrm{~m}$.

- Púlpito. Púlpitos; Anónimo español; 1600-1699; Barroco; Escuela española; Mármol; Labrado, Pulido, Taracea; 2,70 x 2,86 x 1,36 m.

- Santa; Púlpito. Relieves; Anónimo español; 1600-1699; Barroco; Escuela española; Pan. Oro; Pulido, Tallado, Técnica de dorado; 23 x 18 cm.

- Santa; Púlpito. Relieves; Anónimo español; 1600-1699; Barroco; Escuela española; Pan. Oro; Labrado, Pulido, Técnica de dorado; 23 x 18 cm.

- Santo; Púlpito. Relieves; Anónimo español; 1600-1699; Barroco; Escuela española; Pan. Oro; Labrado, Pulido, Técnica de dorado; 29 x $22 \mathrm{~cm}$.

- Santo Papa; Púlpito. Relieves; Anónimo español; 1600-1699; Barroco; Escuela española; Pan. Oro; Labrado, Pulido, Técnica de dorado; 29 x $22 \mathrm{~cm}$.

- Santo Obispo; Púlpito. Relieves; Anónimo español; 1600-1699; Barroco Escuela española; Pan. Oro; Labrado, Pulido, Técnica de dorado; 29 x 22 cm.

- Santo; Púlpito. Relieves; Anónimo español; 1600-1699; Barroco; Escuela española; Pan. Oro; Labrado, Pulido, Técnica de dorado; 29 x 22 cm.

- Retablo de los Fundadores. Retablos; Florentino, Jacobo, llamado "El Indaco", Siloé, Diego de; 1500-1599; Renacimiento ; Escuela española; Piedra; Estucado, Policromado dorado; 9,34 x 7,10 x 0,85 m. 
- Lansquenete; Retablo de los Fundadores. Esculturas de bulto redondo; Anónimo español; 1500-1599; Renacimiento; Escuela española; Piedra; Estucado, Policromado; $1,84 \times 0,50 \times 0,40 \mathrm{~m}$.

- Escudo; Retablo de los Fundadores. Escudos heráldicos; Siloé, Diego de; 1500-1599; Renacimiento; Escuela española; Piedra; Estucado, Policromado Técnica de dorado; 3,36 x 1,93 m.

- Lansquenete; Retablo de los Fundadores. Esculturas de bulto redondo; Anónimo español; 1500-1599; Renacimiento; Escuela española; Piedra; Estucado, Policromado $1,86 \times 0,55 \times 0,40 \mathrm{~m}$.

- La Fortaleza; Retablo de los Fundadores. Esculturas de bulto redondo; Anónimo español; 1500-1599; Renacimiento; Escuela española; Estucado, Policromado; $1,38 \times 1,30 \times 0,35 \mathrm{~m}$.

- Figura masculina; Retablo de los Fundadores. Esculturas de bulto redondo; Anónimo español; 1500-1599; Renacimiento; Escuela española; Piedra, Estucado, Policromado; 90 × 77 × $25 \mathrm{~cm}$.

- La Justicia; Retablo de los Fundadores. Escultura de bulto redondo; Anónimo español; 1500-1599; Renacimiento; Escuela española; Piedra; Estucado, Policromado; $1,35 \times 1,20 \times 0,37 \mathrm{~m}$.

- Vidriera. Pinturas, Vidrieras; Vergara, Arnao de; 1500-1599; Renacimiento; Escuela española; Pigmento, Plomo, Vidrio; Ensamble, Policromado Soplado de vidrio; 2,12 x 2,14 m.

- Calvario. Pinturas, Vidrieras; Vergara, Arnao de; 1500-1599; Renacimiento; Escuela española; Pigmento, Plomo, Vidrio; Ensamble, Policromado, Soplado de vidrio; 3 x 2,08 m.

- La Oración de Getsemaní. Pinturas, Vidrieras; Vergara, Arnao de; 15001599; Renacimiento; Escuela española; Pigmento, Plomo, Vidrio; Ensamble, Policromado, Soplado de vidrio; 2,12 x 2,14 m.

- Frontal de altar. Frontales de altar; Anónimo español; 1500-1599; Renacimiento; Escuela española; Mármol; Cincelado, Labrado, Pulido; 1,02 x 2,19 $\mathrm{m}$.

- Frontal de altar. Frontales de altar; Anónimo español; 1500-1599; Renacimiento; Escuela española; Mármol; Cincelado, Labrado; 1,04 x 3,40 m.

- La Ascensión. Pinturas, Vidrieras; Vergara, Arnao de; 1500-1599; Renacimiento; Escuela española; Pigmento, Plomo, Vidrio; Ensamble, Pintura al óleo, Soplado de vidrio; 2,12 x 2,14 m. 
- Atril. Atriles, Mobiliario; Anónimo español; 1600-1799; Barroco; Escuela española; Madera; Técnica de ebanistería; 1,27 x 0,63 x 0,57 m.

- Mesa. Mesas, Mobiliario; Anónimo español; 1600-1699; Barroco; Escuela española; Hierro, Madera; Técnica de ebanistería; 0,85 x 1,66 x 0,90 m.

- San Jerónimo y San Gregorio Magno. Pinturas, Pinturas de caballete; Anónimo español; 1650-1699; Barroco; Escuela granadina; Pigmento. Aceite; Pintura al óleo; 2,14 x 1,66 m.

- San Ambrosio y San Agustín. Pinturas, Pinturas de caballete; Anónimo español; 1650-1699; Barroco; Escuela española; Pigmento. Aceite; Pintura al óleo $2,14 \times 1,66 \mathrm{~m}$.

- Caja de órgano. Tipologías: Cajas del órgano; Anónimo español; $1585-$ 1614; Barroco; Escuela granadina; Pan. Oro, Pigmento; Ensamble, Policromado Tallado; $5,51 \times 2,48 \times 0,80 \mathrm{~m}$.

- San Miguel arcángel. Esculturas de bulto redondos; Ruiz del Peral, Torcuato, Seguidor de; 1700-1714; Barroco; Escuela granadina; Pan. Oro, Pigmento; Estofado Policromado Tallado; 1,03 x 0,54 x 0,50 m.

- Virgen con el Niño. Esculturas de bulto redondo, Balduque, Roque de; 1585-1614; Renacimiento; Escuela española; Pan. Oro, Pigmento; Estofado Policromado Tallado; $1,90 \times 0,80 \times 0,67 \mathrm{~m}$.

- Niño Jesús; Virgen con el Niño. Esculturas de bulto redondo; Balduque, Roque de; 1585-1614; Renacimiento; Escuela española; Pan. Oro, Pigmento; Estofado, Policromado; Tallado; 50 × 30 x $19 \mathrm{~cm}$.

- San Jerónimo. Esculturas de bulto redondo, Esculturas; Anónimo granadino; 1600-1699; Barroco Escuela granadina; San Jerónimo; Pan. Oro, Pigmento; Estofado, Policromado, Tallado; 1,44 x 0,86 x 0,57 m.

- Santa Paula. Esculturas de bulto redondo; Anónimo granadino; 16001699; Barroco Escuela granadina; Pan. Oro, Pigmento; Policromado Tallado, Técnica de dorado; $1,40 \times 0,62 \times 0,44 \mathrm{~m}$.

- San Gabriel arcángel. Esculturas de bulto redondo, Ruiz del Peral, Torcuato, Seguidor de; 1700-1799; Barroco Escuela granadina; Pan. Oro, Pigmento; Estofado, Policromado, Tallado; 1,01 x 0,67 x 0,45 m.

- Ángel niño. Esculturas de bulto redondo; 1600-1799; Barroco Escuelas: Escuela granadina; Pan. Oro, Pigmento; Policromado, Tallado; 62 x 42 x $31 \mathrm{~cm}$.

- Ángel niño. Esculturas de bulto redondo; Anónimo español; 1600-1799; Barroco Escuela granadina; Pigmento; Policromado, Tallado; 66 x 42 x $31 \mathrm{~cm}$. 
- Ángel niño. Esculturas de bulto redondo; Anónimo español; 1600-1799; Barroco Escuela granadina; Pan. Oro, Pigmento; Policromado, Tallado; 48 x 28 x $9 \mathrm{~cm}$.

- Ángel niño. Esculturas de bulto redondo; Anónimo español; 1600-1799; Barroco; Escuela granadina; Pan. Oro, Pigmento; Policromado, Tallado; 63 x 33 x $20 \mathrm{~cm}$.

- Retablo de San Jerónimo. Retablos. Capillas mayores; Aragón, Juan, Gaviria, Bernabé de, Martínez Montañés, Juan, Navas, Diego de, Orea, Pedro de, Pesquera, Diego de, Raxis, Pedro de, Rojas, Pablo de, Vázquez, Juan Bautista, llamado "el Mozo" o "El Jo, Velasco, Lázaro de; 1570-1605; Renacimiento Escuela granadina; San Jerónimo; Pan. Oro, Pigmento; Técnicas: Ensamble, Tallado, Técnica de dorado.

- Gran Capitán; Retablo de San Jerónimo. Esculturas de bulto redondo; Gabiria, Bernabé de, Martínez Montañés, Juan, Navas, Diego de, Raxis, Pedro de, Rojas, Pablo de; 1573-1573; Renacimiento; Escuela granadina; Pan. Oro, Pigmento; Estofado, Policromado y Tallado; 1,62 x 0,57 x 0,75 m.

- Doña María Manrique; Retablo de San Jerónimo. Esculturas de bulto redondo; Gabiria, Bernabé de, Martínez Montañés, Juan, Navas, Diego de, Raxis, Pedro de, Rojas, Pablo de; 1573-1573; Renacimiento; Escuela granadina; Pan. Oro, Pigmento; Estofado, Policromado y Tallado; 1,62 x 0,60 x 0,74 m.

- Santa Ursúla y Susana; Retablo de San Jerónimo. Relieves; Gabiria, Bernabé de, Martínez Montañés, Juan, Navas, Diego de, Raxis, Pedro de, Rojas, Pablo de; 1573-1573; Renacimiento; Escuela granadina; Pan. Oro, Pigmentos; Policromado, Tallado, Dorado; 80 x $62 \mathrm{~cm}$.

- San Cosme y San Damián; Retablo de San Jerónimo. Relieves; Gabiria, Bernabé de, Martínez Montañés, Juan, Navas, Diego de, Raxis, Pedro de, Rojas, Pablo de; 1573-1573; Renacimiento; Escuela granadina; Pan. Oro, Pigmentos; Policromado, Tallado, Dorado; 0,80 x 1,06 m.

- San Martín; Retablo de San Jerónimo. Relieves; Gabiria, Bernabé de, Martínez Montañés, Juan, Navas, Diego de, Raxis, Pedro de, Rojas, Pablo de; 1573-1573; Renacimiento; Escuela granadina; Pan. Oro, Pigmentos; Policromado, Tallado, Dorado; 0,80 x 1,03 m.

- Constantino a caballo; Retablo de San Jerónimo. Relieves; Gabiria, Bernabé de, Martínez Montañés, Juan, Navas, Diego de, Raxis, Pedro de, Rojas, Pablo de; 1573-1573; Renacimiento; Escuela granadina; Pan. Oro, Pigmento; Estofado, Policromado y Tallado; 0,80 x 1,03 m.

- Santa María egipcíaca; Retablo de San Jerónimo. Relieves; Gabiria, Bernabé de, Martínez Montañés, Juan, Navas, Diego de, Raxis, Pedro de, Rojas, 
Pablo de; 1573-1573; Renacimiento; Escuela granadina; Pan. Oro, Pigmento; Policromado, Tallado, Dorado; 0,80 x 1,06 m.

- San Esteban y San Bartolomé; Retablo de San Bartolomé. Relieves; Gabiria, Bernabé de, Martínez Montañés, Juan, Navas, Diego de, Raxis, Pedro de, Rojas, Pablo de; 1573-1573; Renacimiento; Escuela granadina; Pan. Oro, Pigmento; Policromado, Tallado, Dorado; 80 x $62 \mathrm{~cm}$.

- San Marcos; Retablo de San Jerónimo. Relieves; Gabiria, Bernabé de, Martínez Montañés, Juan, Navas, Diego de, Raxis, Pedro de, Rojas, Pablo de; 1573-1573; Renacimiento; Escuela granadina; Pan. Oro, Pigmento; Policromado, Tallado, Dorado; 75 x $62 \mathrm{~cm}$.

- San Ildefonso; Retablo de San Jerónimo. Relieves; Gabiria, Bernabé de, Martínez Montañés, Juan, Navas, Diego de, Raxis, Pedro de, Rojas, Pablo de; 1573-1573; Renacimiento; Escuela granadina; Pan. Oro, Pigmento; Policromado, Tallado, Dorado; 0,75 x 1,05 m.

- Santos padres León y Ambrosio; Retablo de San Jerónimo. Relieves; Gabiria, Bernabé de, Martínez Montañés, Juan, Navas, Diego de, Raxis, Pedro de, Rojas, Pablo de; 1573-1573; Renacimiento; Escuela granadina; Pan. Oro, Pigmento; Policromado, Tallado, Dorado; 0,75 x 1,05 m.

- San Juan Evangelista; Retablo de San Jerónimo. Relieves; Gabiria, Bernabé de, Martínez Montañés, Juan, Navas, Diego de, Raxis, Pedro de, Rojas, Pablo de; 1573-1573; Renacimiento; Escuela granadina; Pan. Oro, Pigmento; Policromado, Tallado, Dorado; 75 x $60 \mathrm{~cm}$.

- San Lucas; Retablo de San Jerónimo. Relieves; Gabiria, Bernabé de, Martínez Montañés, Juan, Navas, Diego de, Raxis, Pedro de, Rojas, Pablo de; 1573-1573; Renacimiento; Escuela granadina; Pan. Oro, Pigmento; Policromado, Tallado, Dorado; 75 x $60 \mathrm{~cm}$.

- Santos padres San Jerónimo y San Agustín; Retablo de San Jerónimo. Relieves; Gabiria, Bernabé de, Martínez Montañés, Juan, Navas, Diego de, Raxis, Pedro de, Rojas, Pablo de; 1573-1573; Renacimiento; Escuela granadina; Pan. Oro, Pigmento; Policromado, Tallado, Dorado; 0,75 x 1,05 m.

- San Bartolomé; Retablo de San Jerónimo. Relieves; Gabiria, Bernabé de, Martínez Montañés, Juan, Navas, Diego de, Raxis, Pedro de, Rojas, Pablo de; 1573-1573; Renacimiento; Escuela granadina; Pan. Oro, Pigmento; Policromado, Tallado, Dorado; 0,75 x 1,05 m.

- San Bernardo; Retablo de San Jerónimo. Esculturas de bulto redondo; Gabiria, Bernabé de, Martínez Montañés, Juan, Navas, Diego de, Raxis, Pedro de, Rojas, Pablo de; 1573-1573; Renacimiento; Escuela granadina; Pan. Oro, Pigmento Policromado Tallado, Dorado; 1,57 x 0,60 x 0,42 m. 
- Santa Margarita; Retablo de San Jerónimo. Relieves; Gabiria, Bernabé de, Martínez Montañés, Juan, Navas, Diego de, Raxis, Pedro de, Rojas, Pablo de; 1573-1573; Renacimiento; Escuela granadina; Pan. Oro, Pigmento; Policromado, Tallado, Dorado; 1,85 x 1,05 m.

- La Adoración de los magos; Retablo de San Jerónimo. Relieves; Gabiria, Bernabé de, Martínez Montañés, Juan, Navas, Diego de, Raxis, Pedro de, Rojas, Pablo de; 1573-1573; Renacimiento; Escuela granadina; Pan. Oro, Pigmento; Policromado, Tallado, Dorado; 1,85 x 1,05 m.

- San Pablo; Retablo de San Jerónimo. Esculturas de bulto redondo; Gabiria, Bernabé de, Martínez Montañés, Juan, Navas, Diego de, Raxis, Pedro de, Rojas, Pablo de; 1573-1573; Renacimiento; Escuela granadina; Pan. Oro, Pigmento Estofado Policromado Tallado; 1,77 x 0,66 x 0,46 m.

- San Pedro; Retablo de San Jerónimo. Esculturas de bulto redondo; Gabiria, Bernabé de, Martínez Montañés, Juan, Navas, Diego de, Raxis, Pedro de, Rojas, Pablo de; 1573-1573; Renacimiento; Escuela granadina; Pan. Oro, Pigmento Estofado, Policromado, Tallado; 1,74 x 0,34 x 0,42 m.

- La Adoración de los pastores; Retablo de San Jerónimo. Relieves; Gabiria, Bernabé de, Martínez Montañés, Juan, Navas, Diego de, Raxis, Pedro de, Rojas, Pablo de; 1573-1573; Renacimiento; Escuela granadina; Pan. Oro, Pigmento Estofado, Policromado, Tallado; 1,85 x 1,05 m.

- Santa Catalina y Santa Bárbara; Retablo de San Jerónimo. Relieves; Gabiria, Bernabé de, Martínez Montañés, Juan, Navas, Diego de, Raxis, Pedro de, Rojas, Pablo de; 1573-1573; Renacimiento; Escuela granadina; Pan. Oro, Pigmento; Policromado, Tallado y Dorado; 1,85 x 1,05 m.

- San Benito; Retablo de San Jerónimo. Escultura de bulto redondo; Gabiria, Bernabé de, Martínez Montañés, Juan, Navas, Diego de, Raxis, Pedro de, Rojas, Pablo de; 1573-1573; Renacimiento; Escuela granadina; Pan. Oro, Pigmento; Estofado, Policromado, Tallado; 1,52 x 0,71 x 0,56 m.

- San Francisco de Así; Retablo de San Jerónimo. Escultura de bulto redondo; Gabiria, Bernabé de, Martínez Montañés, Juan, Navas, Diego de, Raxis, Pedro de, Rojas, Pablo de; 1573-1573; Renacimiento; Escuela granadina; Pan. Oro, Pigmento; Policromado, Tallado y Dorado; 1,62 x 0,78 x 0,48 m.

- Santa María Magdalena; Retablo de San Jerónimo. Relieves; Gabiria, Bernabé de, Martínez Montañés, Juan, Navas, Diego de, Raxis, Pedro de, Rojas, Pablo de; 1573-1573; Renacimiento; Escuela granadina; Pan. Oro, Pigmento; Policromado, Tallado y Dorado; 1,85 x 1,05 m.

- Presentación de Jesús en el templo; Retablo de San Jerónimo. Relieves; Gabiria, Bernabé de, Martínez Montañés, Juan, Navas, Diego de, Raxis, Pedro de, 
Rojas, Pablo de; 1573-1573; Renacimiento; Escuela granadina; Pan. Oro, Pigmento; Estofado, Policromado, Tallado; 1,85 x 1,05 m.

- San Juan Evangelista; Retablo de San Jerónimo. Escultura de bulto redondo; Gabiria, Bernabé de, Martínez Montañés, Juan, Navas, Diego de, Raxis, Pedro de, Rojas, Pablo de; 1573-1573; Renacimiento; Escuela granadina; Pan. Oro, Pigmento; Estofado, Policromado, Tallado; 1,74 x 0,60 x 0,45 m.

- Inmaculada; Retablo de San Jerónimo. Esculturas de bulto redondo; Gabiria, Bernabé de, Martínez Montañés, Juan, Navas, Diego de, Raxis, Pedro de, Rojas, Pablo de; 1573-1573; Renacimiento; Escuela granadina; Pan. Oro, Pigmento Estofado, Policromado, Tallado; $1,56 \times 0,56 \times 0,40 \mathrm{~m}$.

- Santa Ana; Retablo de San Jerónimo. Esculturas de busto; Gabiria, Bernabé de, Martínez Montañés, Juan, Navas, Diego de, Raxis, Pedro de, Rojas, Pablo de; 1573-1573; Renacimiento; Escuela granadina; Pan. Oro, Pigmento; Estofado, Policromado, Tallado; 67 x 50 x $45 \mathrm{~cm}$.

- San Joaquín; Retablo de San Jerónimo. Esculturas de busto; Gabiria, Bernabé de, Martínez Montañés, Juan, Navas, Diego de, Raxis, Pedro de, Rojas, Pablo de; 1573-1573; Renacimiento; Escuela granadina; Pan. Oro, Pigmento; Estofado, Policromado, Tallado; 73 x 53 x $40 \mathrm{~cm}$.

- Inmaculada, San Joaquín y Santa Ana; Retablo de San Jerónimo. Esculturas de bulto redondo; Gabiria, Bernabé de, Martínez Montañés, Juan, Navas, Diego de, Raxis, Pedro de, Rojas, Pablo de; 1573-1573; Renacimiento; Escuela granadina; Pan. Oro, Pigmento; Estofado, Policromado, Tallado;1,56 x $1,22 \times 1,10 \mathrm{~m}$.

- San Juan Bautista; Retablo de San Jerónimo. Esculturas de bulto redondo; Gabiria, Bernabé de, Martínez Montañés, Juan, Navas, Diego de, Raxis, Pedro de, Rojas, Pablo de; 1573-1573; Renacimiento; Escuela granadina; Pan. Oro, Pigmento; Estofado, Policromado, Tallado; 1,66 x 0,45 x 0,50 m.

- La Anunciación; Retablo de San Jerónimo. Relieves; Vázquez, Juan Bautista, llamado "el Mozo" o "El Joven"; 1573-1573; Renacimiento; Escuela granadina; Pan. Oro, Pigmento; Estofado, Policromado, Tallado; 1,85 x 1,05 m.

- Santa Paula y Santa Estoquia; Retablo de San Jerónimo. Relieves; Gabiria, Bernabé de, Martínez Montañés, Juan, Navas, Diego de, Raxis, Pedro de, Rojas, Pablo de; 1573-1573; Renacimiento; Escuela granadina; Pan. Oro, Pigmento Estofado, Policromado, Tallado; 1,85 x 1,05 m.

- San Bernardo; Retablo de San Jerónimo. Esculturas de bulto redondo; Gabiria, Bernabé de, Martínez Montañés, Juan, Navas, Diego de, Raxis, Pedro de, Rojas, Pablo de; 1573-1573; Renacimiento; Escuela granadina; Pan. Oro, Pigmento Policromado Tallado, Dorado; 1,57 x 0,60 x 0,42 m. 
- Santa Margarita; Retablo de San Jerónimo. Relieves; Gabiria, Bernabé de, Martínez Montañés, Juan, Navas, Diego de, Raxis, Pedro de, Rojas, Pablo de; 1573-1573; Renacimiento; Escuela granadina; Pan. Oro, Pigmento; Policromado, Tallado, Dorado; 1,85 x 1,05 m.

- La Adoración de los magos; Retablo de San Jerónimo. Relieves; Gabiria, Bernabé de, Martínez Montañés, Juan, Navas, Diego de, Raxis, Pedro de, Rojas, Pablo de; 1573-1573; Renacimiento; Escuela granadina; Pan. Oro, Pigmento; Policromado, Tallado, Dorado; 1,85 x 1,05 m.

- San Pablo; Retablo de San Jerónimo. Esculturas de bulto redondo; Gabiria, Bernabé de, Martínez Montañés, Juan, Navas, Diego de, Raxis, Pedro de, Rojas, Pablo de; 1573-1573; Renacimiento; Escuela granadina; Pan. Oro, Pigmento Estofado Policromado Tallado; 1,77 x 0,66 x 0,46 m.

- San Pedro; Retablo de San Jerónimo. Esculturas de bulto redondo; Gabiria, Bernabé de, Martínez Montañés, Juan, Navas, Diego de, Raxis, Pedro de, Rojas, Pablo de; 1573-1573; Renacimiento; Escuela granadina; Pan. Oro, Pigmento Estofado, Policromado, Tallado; 1,74 x 0,34 x 0,42 m.

- La Adoración de los pastores; Retablo de San Jerónimo. Relieves; Gabiria, Bernabé de, Martínez Montañés, Juan, Navas, Diego de, Raxis, Pedro de, Rojas, Pablo de; 1573-1573; Renacimiento; Escuela granadina; Pan. Oro, Pigmento Estofado, Policromado, Tallado; 1,85 x 1,05 m.

- Santa Catalina y Santa Bárbara; Retablo de San Jerónimo. Relieves; Gabiria, Bernabé de, Martínez Montañés, Juan, Navas, Diego de, Raxis, Pedro de, Rojas, Pablo de; 1573-1573; Renacimiento; Escuela granadina; Pan. Oro, Pigmento; Policromado, Tallado y Dorado; 1,85 x 1,05 m.

- San Benito; Retablo de San Jerónimo. Escultura de bulto redondo; Gabiria, Bernabé de, Martínez Montañés, Juan, Navas, Diego de, Raxis, Pedro de, Rojas, Pablo de; 1573-1573; Renacimiento; Escuela granadina; Pan. Oro, Pigmento; Estofado, Policromado, Tallado; 1,52 x 0,71 x 0,56 m.

- San Francisco de Así; Retablo de San Jerónimo. Escultura de bulto redondo; Gabiria, Bernabé de, Martínez Montañés, Juan, Navas, Diego de, Raxis, Pedro de, Rojas, Pablo de; 1573-1573; Renacimiento; Escuela granadina; Pan. Oro, Pigmento; Policromado, Tallado y Dorado; 1,62 x 0,78 x 0,48 m.

- Santa María Magdalena; Retablo de San Jerónimo. Relieves; Gabiria, Bernabé de, Martínez Montañés, Juan, Navas, Diego de, Raxis, Pedro de, Rojas, Pablo de; 1573-1573; Renacimiento; Escuela granadina; Pan. Oro, Pigmento; Policromado, Tallado y Dorado; 1,85 x 1,05 m.

- Presentación de Jesús en el templo; Retablo de San Jerónimo. Relieves; Gabiria, Bernabé de, Martínez Montañés, Juan, Navas, Diego de, Raxis, Pedro de, 
Rojas, Pablo de; 1573-1573; Renacimiento; Escuela granadina; Pan. Oro, Pigmento; Estofado, Policromado, Tallado; 1,85 x 1,05 m.

- San Juan Evangelista; Retablo de San Jerónimo. Escultura de bulto redondo; Gabiria, Bernabé de, Martínez Montañés, Juan, Navas, Diego de, Raxis, Pedro de, Rojas, Pablo de; 1573-1573; Renacimiento; Escuela granadina; Pan. Oro, Pigmento; Estofado, Policromado, Tallado; 1,74 x 0,60 x 0,45 m.

- Inmaculada; Retablo de San Jerónimo. Esculturas de bulto redondo; Gabiria, Bernabé de, Martínez Montañés, Juan, Navas, Diego de, Raxis, Pedro de, Rojas, Pablo de; 1573-1573; Renacimiento; Escuela granadina; Pan. Oro, Pigmento Estofado, Policromado, Tallado; $1,56 \times 0,56 \times 0,40 \mathrm{~m}$.

- Santa Ana; Retablo de San Jerónimo. Esculturas de busto; Gabiria, Bernabé de, Martínez Montañés, Juan, Navas, Diego de, Raxis, Pedro de, Rojas, Pablo de; 1573-1573; Renacimiento; Escuela granadina; Pan. Oro, Pigmento; Estofado, Policromado, Tallado; 67 x 50 x $45 \mathrm{~cm}$.

- San Joaquín; Retablo de San Jerónimo. Esculturas de busto; Gabiria, Bernabé de, Martínez Montañés, Juan, Navas, Diego de, Raxis, Pedro de, Rojas, Pablo de; 1573-1573; Renacimiento; Escuela granadina; Pan. Oro, Pigmento; Estofado, Policromado, Tallado; 73 x 53 x $40 \mathrm{~cm}$.

- Inmaculada, San Joaquín y Santa Ana; Retablo de San Jerónimo. Esculturas de bulto redondo; Gabiria, Bernabé de, Martínez Montañés, Juan, Navas, Diego de, Raxis, Pedro de, Rojas, Pablo de; 1573-1573; Renacimiento; Escuela granadina; Pan. Oro, Pigmento; Estofado, Policromado, Tallado; 1,56 x $1,22 \times 1,10 \mathrm{~m}$.

- San Juan Bautista; Retablo de San Jerónimo. Esculturas de bulto redondo; Gabiria, Bernabé de, Martínez Montañés, Juan, Navas, Diego de, Raxis, Pedro de, Rojas, Pablo de; 1573-1573; Renacimiento; Escuela granadina; Pan. Oro, Pigmento; Estofado, Policromado, Tallado; 1,66 x 0,45 x 0,50 m.

- La Anunciación; Retablo de San Jerónimo. Relieves; Vázquez, Juan Bautista, llamado "el Mozo" o "El Joven"; 1573-1573; Renacimiento; Escuela granadina; Pan. Oro, Pigmento; Estofado, Policromado, Tallado; 1,85 x 1,05 m.

- Santa Paula y Santa Estoquia; Retablo de San Jerónimo. Relieves; Gabiria, Bernabé de, Martínez Montañés, Juan, Navas, Diego de, Raxis, Pedro de, Rojas, Pablo de; 1573-1573; Renacimiento; Escuela granadina; Pan. Oro, Pigmento Estofado, Policromado, Tallado; 1,85 x 1,05 m.

- Santo Domingo de Guzmán; Retablo de San Jerónimo. Esculturas de bulto redondo; Gabiria, Bernabé de, Martínez Montañés, Juan, Navas, Diego de, Raxis, Pedro de, Rojas, Pablo de; 1573-1573; Renacimiento; Escuela granadina; Pan. Oro, Pigmento; Estofado Policromado Tallado; 1,56 x 0,71 x 0,65 m. 

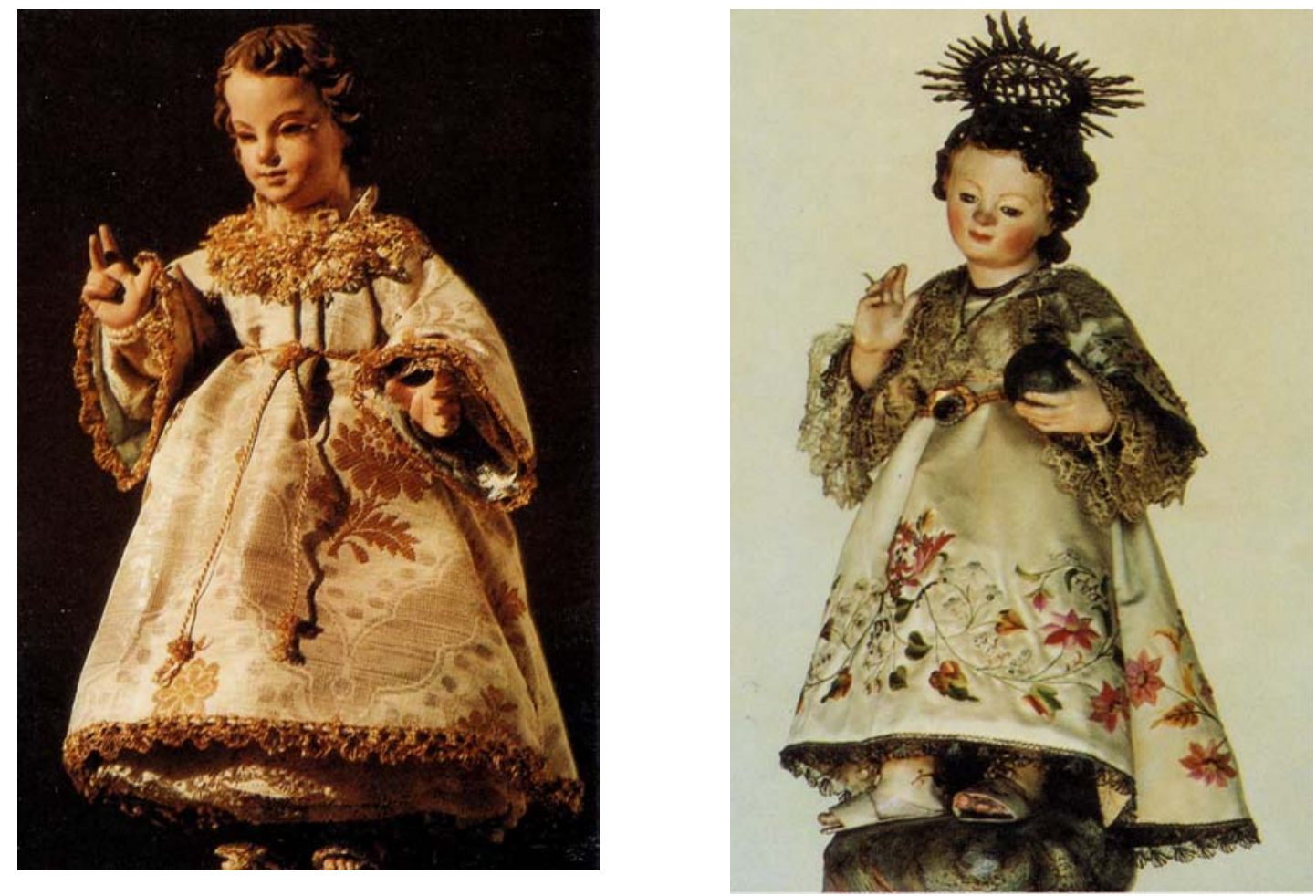

Niños Jesús. Monasterio. de San Jerónimo
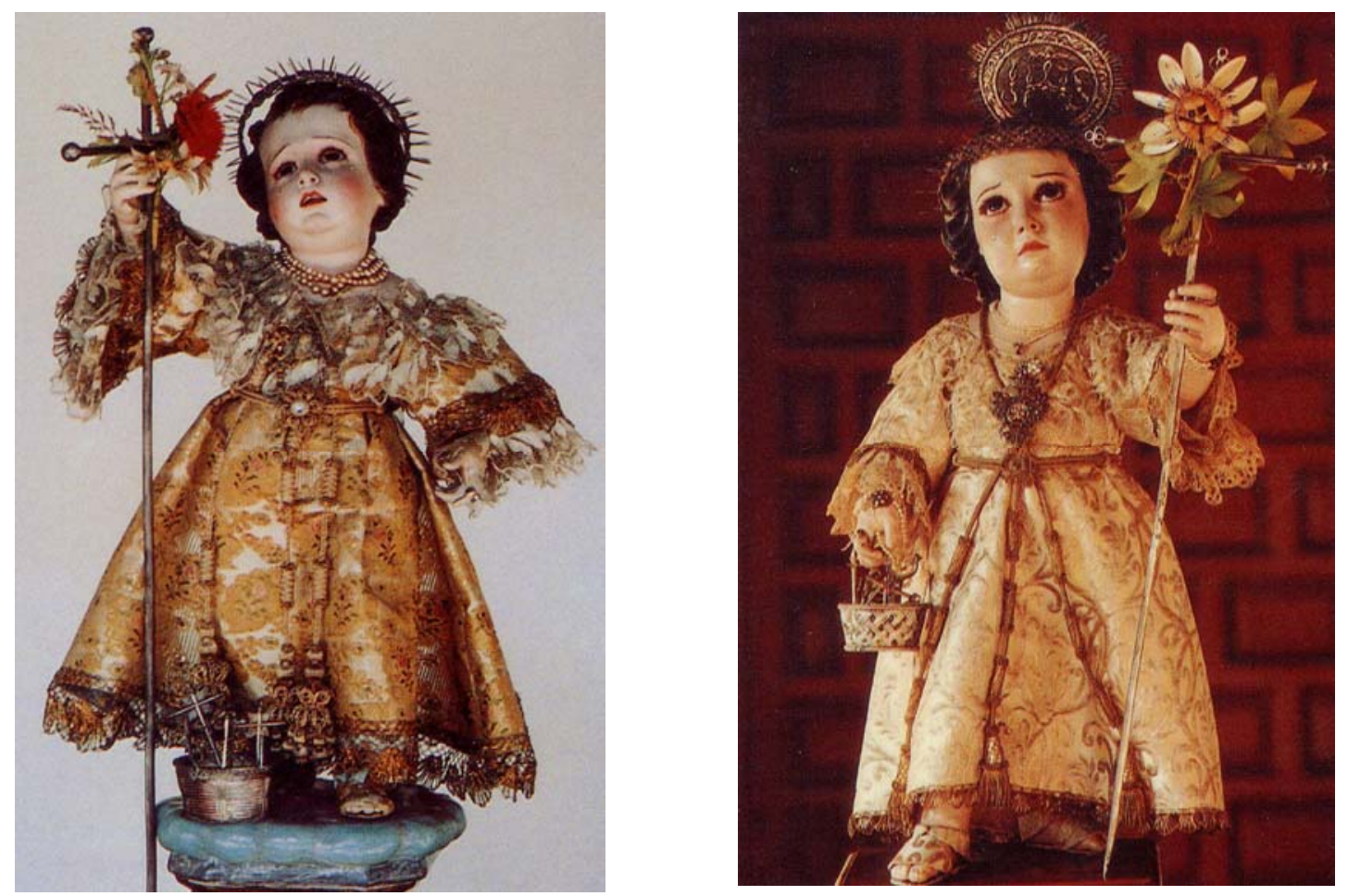

Niños Jesús de la Pasión. Monasterio de San Jerónimo. 
- Santiago; Retablo de San Jerónimo. Esculturas de bulto redondo; Gabiria, Bernabé de, Martínez Montañés, Juan, Navas, Diego de, Raxis, Pedro de, Rojas, Pablo de; 1573-1573; Renacimiento; Escuela granadina; Pan. Oro, Pigmento; Estofado. Policromado, Tallado; 1,60 x 0,71 x 0,44 m.

- Descendimiento; Retablo de San Jerónimo. Relieves; Gabiria, Bernabé de, Martínez Montañés, Juan, Navas, Diego de, Raxis, Pedro de, Rojas, Pablo de; 1573-1573; Renacimiento; Escuela granadina; Pan. Oro, Pigmento; Estofado, Policromado, Tallado; 1,95 x 1,05 m.

- Cristo ayudado por un cirineo; Retablo de San Jerónimo. Relieves; Gabiria, Bernabé de, Martínez Montañés, Juan, Navas, Diego de, Raxis, Pedro de, Rojas, Pablo de; 1573-1573; Renacimiento; Escuela granadina; Pan. Oro, Pigmento; Estofado; Policromado, Tallado; Medidas: 1,95 x 1,05 m.

- Ecce Homo; Retablo de San Jerónimo. Esculturas de bulto redondo; Gabiria, Bernabé de, Martínez Montañés, Juan, Navas, Diego de, Raxis, Pedro de, Rojas, Pablo de; 1573-1573; Renacimiento; Escuela granadina; Pan. Oro, Pigmento; Estofado, Policromado, Tallado; 1,54 x 0,55 x 0,38 m.

- San Jerónimo; Retablo de San Jerónimo. Altorrelieves, Relieves; Gabiria, Bernabé de, Martínez Montañés, Juan, Navas, Diego de, Raxis, Pedro de, Rojas, Pablo de; 1573-1573; Renacimiento; Escuela granadina; Pan. Oro, Pigmentos; Estofado, Policromado, Tallado; 1,95 x 1,33 m.

- Cristo atado a la columna; Retablo de San Jerónimo. Esculturas de bulto redondo; Gabiria, Bernabé de, Martínez Montañés, Juan, Navas, Diego de, Raxis, Pedro de, Rojas, Pablo de; 1573-1573; Renacimiento; Escuela granadina; Pan. Oro, Pigmento; Policromado, Tallado, Técnica de dorado; 1,56 x 0,37 x 0,36 m.

- El Prendimiento; Retablo de San Jerónimo. Relieves; Gabiria, Bernabé de, Martínez Montañés, Juan, Navas, Diego de, Raxis, Pedro de, Rojas, Pablo de; 1573-1573; Renacimiento; Escuela granadina; Pan. Oro, Pigmento; Estofado, Policromado, Tallado; 1,95 x 1,05 m.

- La Oración en el huerto; Retablo de San Jerónimo. Relieves; Gabiria, Bernabé de, Martínez Montañés, Juan, Navas, Diego de, Raxis, Pedro de, Rojas, Pablo de; 1573-1573; Renacimiento; Escuela granadina; Pan. Oro, Pigmento; Estofado, Policromado, Tallado; 1,95 x 1,05 m.

- San Andrés; Retablo de San Jerónimo. Esculturas de bulto redondo; Gabiria, Bernabé de, Martínez Montañés, Juan, Navas, Diego de, Raxis, Pedro de, Rojas, Pablo de; 1573-1573; Renacimiento; Escuela granadina; Pan. Oro, Pigmento Estofado, Policromado, Tallado; $1,53 \times 0,62 \times 0,60 \mathrm{~m}$.

- Templanza; Retablo de San Jerónimo. Esculturas de bulto redondo; Gabiria, Bernabé de, Martínez Montañés, Juan, Navas, Diego de, Raxis, Pedro de, Rojas, Pablo de; 1573-1573; Renacimiento; Escuela granadina; Pan. Oro, Pigmento 
Estofado, Policromado, Tallado; $1,70 \times 0,65$ x 0,60 m.

- La venida del Espíritu Santo; Retablo de San Jerónimo. Relieves; Gabiria, Bernabé de, Martínez Montañés, Juan, Navas, Diego de, Raxis, Pedro de, Rojas, Pablo de; 1605-1605; Renacimiento; Escuela granadina; Pan. Oro, Pigmento Estofado, Policromado, Tallado; 1,85 x 1,30 m.

- San Juan, Calvario; Retablo de San Jerónimo. Esculturas de bulto redondo; Gabiria, Bernabé de, Martínez Montañés, Juan, Navas, Diego de, Raxis, Pedro de, Rojas, Pablo de; 1573-1573; Renacimiento; Escuela granadina; Pan. Oro, Pigmento; Estofado, Policromado, Tallado; 1,55 x 0,62x 0,60 m.

- Crucificado, Calvario; Retablo de San Jerónimo. Esculturas de bulto redondo; Gabiria, Bernabé de, Martínez Montañés, Juan, Navas, Diego de, Raxis, Pedro de, Rojas, Pablo de; 1573-1573; Renacimiento; Escuela granadina; Pan. Oro, Pigmento; Estofado, Policromado, Tallado; 1,55 x 1,60 x 0,45 m.

- Virgen, Calvario; Retablo de San Jerónimo. Esculturas de bulto redondo; Gabiria, Bernabé de, Martínez Montañés, Juan, Navas, Diego de, Raxis, Pedro de, Rojas, Pablo de; 1573-1573; Renacimiento; Escuela granadina; Pan. Oro, Pigmento; Estofado, Policromado, Tallado; 1,50 x 0,62 x 0,60 m.

- Ascensión de Jesús; Retablo de San Jerónimo. Relieves; Gabiria, Bernabé de, Martínez Montañés, Juan, Navas, Diego de, Raxis, Pedro de, Rojas, Pablo de; 1605-1605; Renacimiento; Escuela granadina; Pan. Oro, Pigmento; Estofado, Policromado, Tallado; 1,85 x 1,20 m.

- Justicia; Retablo de San Jerónimo. Esculturas de bulto redondo; Gabiria, Bernabé de, Martínez Montañés, Juan, Navas, Diego de, Raxis, Pedro de, Rojas, Pablo de; 1605-1605; Barroco; Escuela granadina; Pan. Oro, Pigmento; Estofado, Policromado, Tallado; $1,55 \times 0,62 \times 0,60 \mathrm{~m}$.

- Fortaleza; Retablo de San Jerónimo. Esculturas de bulto redondo; Gabiria, Bernabé de, Martínez Montañés, Juan, Navas, Diego de, Raxis, Pedro de, Rojas, Pablo de; 1573-1573; Renacimiento; Escuela granadina; Materiales: Pan. Oro, Pigmento; Estofado, Policromado, Tallado; 1,70 x 0,45 x 0,45 m.

- San Pastor; Retablo de San Jerónimo. Esculturas de bulto redondo; Gabiria, Bernabé de, Martínez Montañés, Juan, Navas, Diego de, Raxis, Pedro de, Rojas, Pablo de; 1605-1605; Barroco; Escuela granadina; Pan. Oro, Pigmento; Estofado, Policromado, Tallado; 1,65 x 0,35 x 0,45 m.

- Padre Eterno; Retablo de San Jerónimo. Esculturas de busto; Gabiria, Bernabé de, Martínez Montañés, Juan, Navas, Diego de, Raxis, Pedro de, Rojas, Pablo de; 1573-1605; Renacimiento; Escuela granadina; Pan. Oro, Pigmento; Estofado, Policromado, Tallado; 1,50 x 1,55 x 0,45 m. 


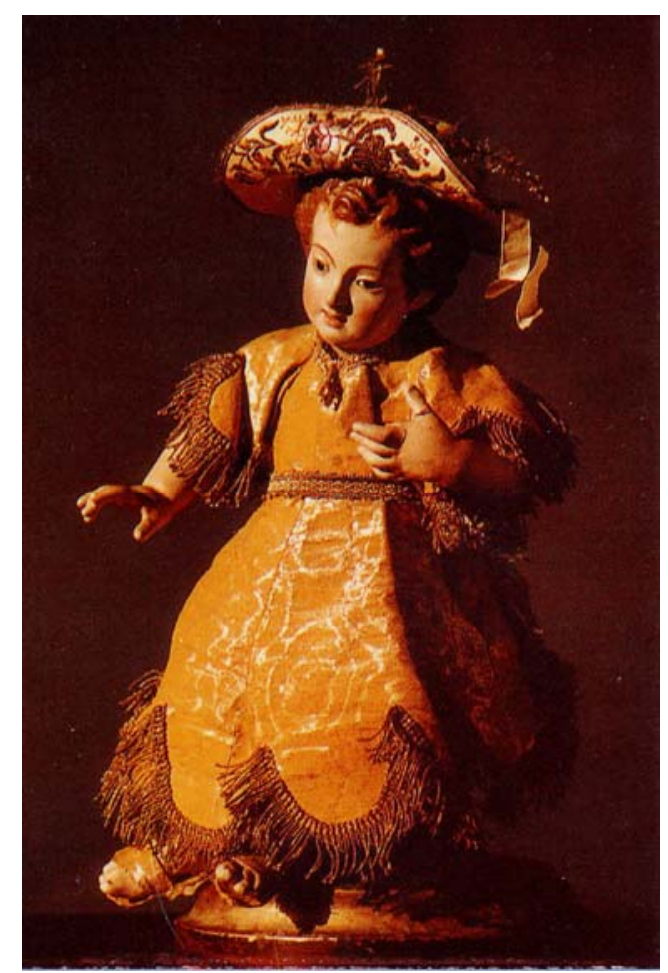

Niño Jesús. Monasterio de San Jerónimo.

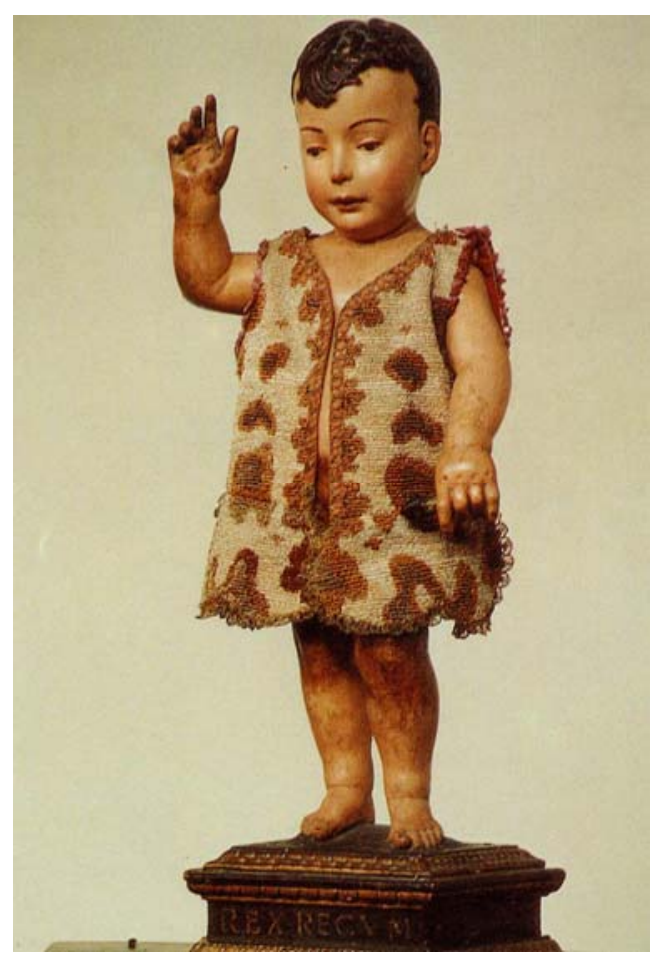

Niño Jesús del Gran Capitán. Monasterio de San Jerónimo.

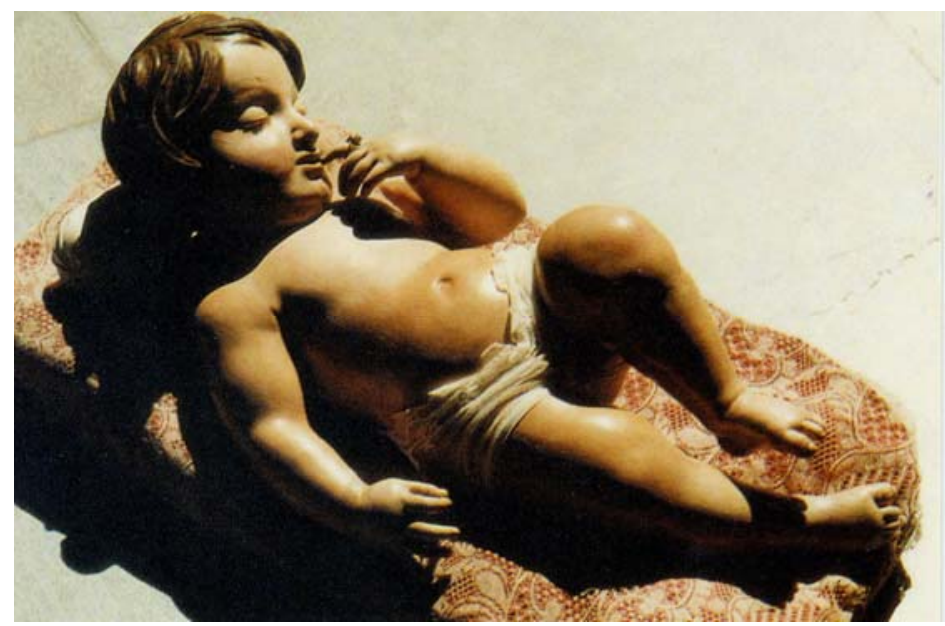

Niño Jesús dormido. Monasterio de San Jerónimo. 
- San Justo; Retablo de San Jerónimo. Esculturas de bulto redondo; Gabiria, Bernabé de, Martínez Montañés, Juan, Navas, Diego de, Raxis, Pedro de, Rojas, Pablo de; 1605-1605; Barroco; Escuela granadina; Pan. Oro, Pigmento; Estofado, Policromado, Tallado; 1,65 x 0,55 x 0,45 m.

- Caridad; Retablo de San Jerónimo. Esculturas de bulto redondo; Gabiria, Bernabé de, Martínez Montañés, Juan, Navas, Diego de, Raxis, Pedro de, Rojas, Pablo de; 1573-1573; Renacimiento; Escuela granadina; Pan. Oro, Pigmento; Estofado, Policromado, Tallado; 0,60 x 1,50 x 0,45 m.

- Templanza; Retablo de San Jerónimo. Esculturas de bulto redondo; Gabiria, Bernabé de, Martínez Montañés, Juan, Navas, Diego de, Raxis, Pedro de, Rojas, Pablo de; 1573-1573; Renacimiento; Escuela granadina; Pan. Oro, Pigmento; Estofado, Policromado, Tallado; 1,50 x 1,65 x 0,50 m.

- Esperanza; Retablo de San Jerónimo. Esculturas de bulto redondo; Gabiria, Bernabé de, Martínez Montañés, Juan, Navas, Diego de, Raxis, Pedro de, Rojas, Pablo de; 1573-1573; Renacimiento; Escuela granadina; Pan. Oro, Pigmento; Estofado, Policromado, Tallado; 1,60 x 0,50 x 0,50 m.

- Escudo; Retablo de San Jerónimo. Escudos heráldicos; Gabiria, Bernabé de, Navas, Diego de, Raxis, Pedro de; 1605-1605; Renacimiento; Escuela española; Pan. Oro, Pigmento; Policromado, Tallado, Técnica de dorado; 2,08 x 1,37 m.

- Escudo; Retablo de San Jerónimo. Escudos heráldicos; Gabiria, Bernabé de, Navas, Diego de, Raxis, Pedro de; 1605-1605; Renacimiento; Escuela española; Pan. Oro, Pigmento; Policromado, Tallado, Técnica de dorado; 2,08 x 1,37 m.

- Virgen con el Niño. Esculturas de bulto redondo; Anónimo español; 1500-1599; Renacimiento; Escuela española; Pan. Oro, Pigmento; Estofado, Policromado, Tallado; 78 × 28 × $30 \mathrm{~cm}$.

- Peana. Peanas; Anónimo español; 1600-1699; Barroco; Escuela granadina; Pigmento; Policromado, Tallado; 29 x 34 x $34 \mathrm{~cm}$.

- San Pedro. Esculturas de bulto redondo; Anónimo español; 1600-1699; Barroco; Escuela granadina; Pan. Oro, Pigmento; Estofado, Policromado, Tallado; $1,34 \times 0,62 \times 0,56 \mathrm{~m}$.

- Caja de órgano. Cajas del órgano; Anónimo español; 1700-1799; Barroco Escuela española; Pan. Oro, Pigmento; Policromado, Tallado, Técnica de dorado; $9,17 \times 6,20 \times 2 \mathrm{~m}$.

- Angelillo; Órgano. Esculturas de bulto redondo, Anónimo español; 17001799; Barroco Escuela española; Ángeles; Pigmento; Policromado, Tallado; 50 x $20 \times 12 \mathrm{~cm}$. 
- Angelito. Órgano. Esculturas de bulto redondo; Anónimo español; 17001799; Barroco; Escuela española; Pigmento; Policromado, Tallado; 70 x 30 x 30 $\mathrm{cm}$.

- Angelito; Órgano. Esculturas de bulto redondo; Anónimo español; 17001799; Barroco (Estilo); Escuela española; Pigmento Policromado, Tallado; 70 x 30 $\mathrm{x} 30 \mathrm{~cm}$.

- Angelito; Órgano. Esculturas de bulto redondo; Anónimo español; 17001799; Barroco; Escuela española; Pigmento; Policromado, Tallado; 50 × 20 x 15 $\mathrm{cm}$.

- Figura femenina; Órgano. Esculturas de bulto redondo; Anónimo español; 1700-1799; Barroco Escuela española; Pigmento; Policromado, Tallado; $1,70 \times 0,60 \times 0,40 \mathrm{~m}$.

- Caja de órgano. Cajas del órgano; Anónimo español; 1700-1799; Barroco Escuela española; Pan. Oro, Pigmento; Policromado, Técnica de dorado, Técnica de ebanistería; 8,20 × 4,90 × 2 m.

- Ángel; Órgano. Esculturas de bulto redondo; Anónimo español; 17001799; Barroco Escuela española; Pigmento; Policromado, Tallado; 1,20 x 0,25 x $0,40 \mathrm{~m}$.

- Órgano. Órganos (Instrumentos); Anónimo español; 1700-1799; Estilos: Barroco Escuelas: Escuela española; Pan. Oro, Pigmento; Policromado, Técnica de dorado, Técnica de ebanistería; 2,92 x 2,40 x 0,60 m.

-Tabernáculo. Tabernáculos; Anónimo español; 1700-1799; Barroco; Escuela granadina; Pan. Oro, Pigmento; Policromado, Tallado, Técnica de dorado; $3 \times 2,53 \mathrm{~m}$.

- Virgen de Belén. Esculturas de bulto redondo; Anónimo español, Círculo de los Mora; 1650-1699; Barroco Escuelas: Escuela granadina; Pan. Oro, Pigmento; Estofado (Técnica), Policromado (Técnica), Tallado; 1,10 x 0,70 x 0,63 $\mathrm{m}$.

- Apóstoles. Pinturas, Pinturas de caballete; Anónimo español; 1600-1699; Barroco (Estilo); Escuela granadina; Pigmento. Aceite; Pintura al óleo (Técnica); $1,62 \times 1,16 \mathrm{~m}$.

- Martirio de San Bartolomé. Pinturas, Pinturas de caballete; Anónimo español; 1700-1799; Barroco (Estilo); Escuela granadina; Pigmento. Aceite; Pintura al óleo (Técnica); 1,63 x 1,17 m.

- Retablo de San Miguel. Retablos. Capillas de iglesias; Anónimo español; 1700-1714; Barroco (Estilo); Escuela granadina; Pan. Oro, Pigmento; Estofado (Técnica), Policromado (Técnica), Tallado; 4,35 x 2,90 x 1,10 m. 
- San Miguel arcángel; Retablo de San Miguel. Esculturas de bulto redondo; Anónimo español; 1600-1614; Barroco; Escuela granadina; Pan. Oro, Pigmentos; Estofado, Policromado, Tallado; 1,70 x 0,95 x 0,50 m.

- San José con el Niño. Pinturas, Pinturas de caballete; Anónimo español; 1685-1714; Barroco; Escuela granadina; Pigmentos, Aceite; Pintura al óleo 80 x $60 \mathrm{~cm}$.

- San José con el Niño; Frontal de altar. Relieves; Anónimo español; 1700-1799; Barroco; Escuela granadina; Pigmentos; Labrado, Policromado 60 x 27 $\mathrm{cm}$.

- Frontal de altar. Frontales de altar; Anónimo español; 1600-1799; Barroco; Escuela granadina; Pigmentos; Tallado, Embutido; 1 x 2,75 m.

- San Francisco de Asís. Esculturas de bulto redondo; Anónimo español; 1600-1614; Barroco; Escuela granadina; Pan. Oro, Pigmento; Estofado, Policromado, Tallado; $1,10 \times 0,52 \times 0,34 \mathrm{~m}$.

- San Francisco de Paula. Esculturas de bulto redondo, Anónimo español; 1650-1699; Barroco; Escuela granadina; Pan. Oro, Pigmento; Estofado, Policromado, Tallado; 1,37 x 0,57 x 0,52 m.

- Virgen de la Soledad. Pinturas, Pinturas de caballete; Anónimo español; 1650-1699; Barroco; Escuela granadina; Pigmento. Aceite; Pintura al óleo; 1,56 x $1,11 \mathrm{~m}$

- Santa Rosa de Lima. Pinturas, Pinturas de caballete; Anónimo español; 1685-1714; Barroco; Escuela granadina; Pigmento. Aceite; Pintura al óleo; 1,42 x $0,89 \mathrm{~m}$.

- Inmaculada Concepción. Pinturas, Pinturas de caballete; Cano, Alonso; 1650-1699; Barroco; Escuela granadina; Pigmento. Aceite; Pintura al óleo: 2 x $1,44 \mathrm{~m}$.

- Pila lavamanos. Pilas de agua bendita. Adosado; Anónimo español; 1500-1599; Renacimiento; Escuela española; Mármol; Labrado, Pulido;1,80 x 0,88 x $0,65 \mathrm{~m}$.

- La Caridad. Relieves; Anónimo español; 1500-1599; Renacimiento; Escuela española; Piedra; Labrado; 1,20 x 1,20 m.

- Consola. Consolas, Mobiliario; Anónimo español; 1600-1699; Barroco ; Escuela granadina; Mármol; Labrado, Pulido; 1,14 x 0,94 x 0,70 m. 
- Cajonería. Cajonerías, Mobiliario; Anónimo español; 1600-1699; Barroco; Escuela española; Madera, Metal, Vidrio; Ebanistería; 1,84 x 4,22 x 0,88 $\mathrm{m}$.

- Banco. Bancos (Asientos)., Mobiliario; Anónimo español; 1700-1799; Barroco; Escuela española; Madera; Ebanistería; 0,96 x 2,34 x 0,58 m.

- Atril. Atriles, Mobiliario; Anónimo español; 1500-1599; Renacimiento; Escuela española; Hierro; Forjado, Repujado; 1,10 x 0,44 x 0,43 m.

- Dos bichas sosteniendo un escudo; Atril. Relieves; Anónimo español; 1500-1599; Renacimiento; Escuela española; Hierro; Forjado, Repujado; 30 x 43,5 $\mathrm{cm}$.

- San Juan Evangelista; Atril. Relieves; Anónimo español; 1500-1599; Renacimiento; Escuela española; Hierro; Forjado, Repujado; 27,5 x 34,5 cm.

- Santo; Atril. Relieves; Anónimo español; 1500-1599; Renacimiento; Escuela española; Hierro; Forjado, Repujado; 27,5 x 34,5 cm.

- Angelitos sosteniendo un escudo; Atril. Relieves; Anónimo español; 1500-1599; Renacimiento; Escuela española; Hierro; Forjado, Repujado; 30 x 43,5 $\mathrm{cm}$.

- Puerta. Mobiliario, Puertas de cuarterones; Anónimo español; 16001699; Barroco; Escuela española; Madera, Metal; Ebanistería; 2,90 x 1,68 m.

- Cajonería. Cajonerías, Mobiliario; Anónimo español; 1600-1699; Barroco; Escuela española; Hierro, Madera; Ebanistería; 1,18 x 2,92 m.

- Puerta. Mobiliario, Puertas, Puertas de cuarterones; Anónimo español; 1600-1699; Barroco; Escuela española; Madera, Metal; Ebanistería; 2,56 x 1,53 m.

- Cornucopia. Cornucopias, Mobiliario; Anónimo español; 1600-1699; Barroco; Escuela española; Pan. Oro, Pigmentos; Policromado, Tallado, Dorado; $96 \times 73 \mathrm{~cm}$.

- Sillón frailero. Mobiliario, Sillones frailero; Anónimo español; 16001699; Barroco; Escuela española; Damasco, Madera, Metal; Técnica de ebanistería; 1,10 x 0,73 × $0,62 \mathrm{~m}$.

- Silla. Mobiliario, Sillas; Anónimo español; 1750-1799; Barroco; Escuela española; Damasco, Madera; Técnica de ebanistería; 1,01 x 0,50 x 0,50 m.

- Mesa. Mobiliario; Anónimo español; 1600-1699; Barroco; Escuela española; Hierro, Mármol; Forjado, Labrado, Pulido; 1,05 x 2,46 x 1,93 m. 
- Reclinatorio. Mobiliario; Anónimo español; 1800-1899; Neo. Gótico Escuela española; Madera; Ebanistería; 92 x 62 × $50 \mathrm{~cm}$.

- Reclinatorio. Mobiliario; Anónimo español; 1800-1899; Neo. Gótico; Escuela española; Cuero, Madera; Ebanistería; 89 x 57 x $62 \mathrm{~cm}$.

- Arcón. Arcones, Mobiliario; Anónimo español; 1500-1599; Renacimiento; Escuela española; Madera, Metal; Ebanistería; 0,50 x 1,60 x 0,62 m.

- Farol. Faroles, Mobiliario; Anónimo español; 1600-1699; Barroco; Escuela española; Metal, Vidrio; Soldado (Unión); 1,32 x 0,45 x 0,45 m.

- La Coronación de espinas. Pinturas, Pinturas de caballete; Anónimo español; 1600-1699; Barroco; Escuela española; Pigmento. Aceite; Pintura al óleo $70 \times 95 \mathrm{~cm}$.

- San Jerónimo penitente. Pinturas, Pinturas de caballete; Anónimo español; 1600-1699; Barroco; Escuela española; Pigmento. Aceite; Pintura al óleo $1,46 \times 1,11 \mathrm{~m}$.

- Marco; San Jerónimo penitente. Marcos (Cuadros); Anónimo español; 1600-1699; Barroco; Escuela española; Pan. Oro, Pigmento; Policromado, Tallado, Técnica de dorado; $1,70 \times 1,38 \mathrm{~m}$.

- Reloj. Relojes. Paredes; Anónimo español; 1700-1799; Barroco; Escuela española; Pigmentos; Policromado, Repujado, Técnica de ebanistería; 2,08 x 0,43 x $0,31 \mathrm{~m}$.

- Consola. Consolas, Mobiliario; Anónimo español; 1800-1899; Neoclasicismo; Escuela española; Madera, Vidrio; Técnica de ebanistería; 1,95 x $0,93 \times 0,65 \mathrm{~m}$.

- Banco. Bancos (Asientos), Mobiliario; Anónimo español; 1600-1699; Barroco; Escuela española; Madera; Ebanistería; 1 x 2,16 x 0,51 m.

- Urna. Mobiliario, Urnas; Anónimo español; 1600-1699; Barroco; Escuela española; Madera, Metal, Vidrio; Repujado, Tallado, Técnica de dorado; 1,09 x $0,63 \times 0,58 \mathrm{~m}$.

- Santa Apolonia. Pinturas, Pinturas de caballete; Anónimo español; 16001699; Escuela española; Pigmentos. Aceite; Pintura al óleo 1,29 x 0,53 m.

- San Jerónimo penitente. Esculturas de bulto redondo; Anónimo español; 1600-1699; Barroco; Escuela española; Pigmentos; Policromado, Tallado; 49 x 19 x $34 \mathrm{~cm}$. 

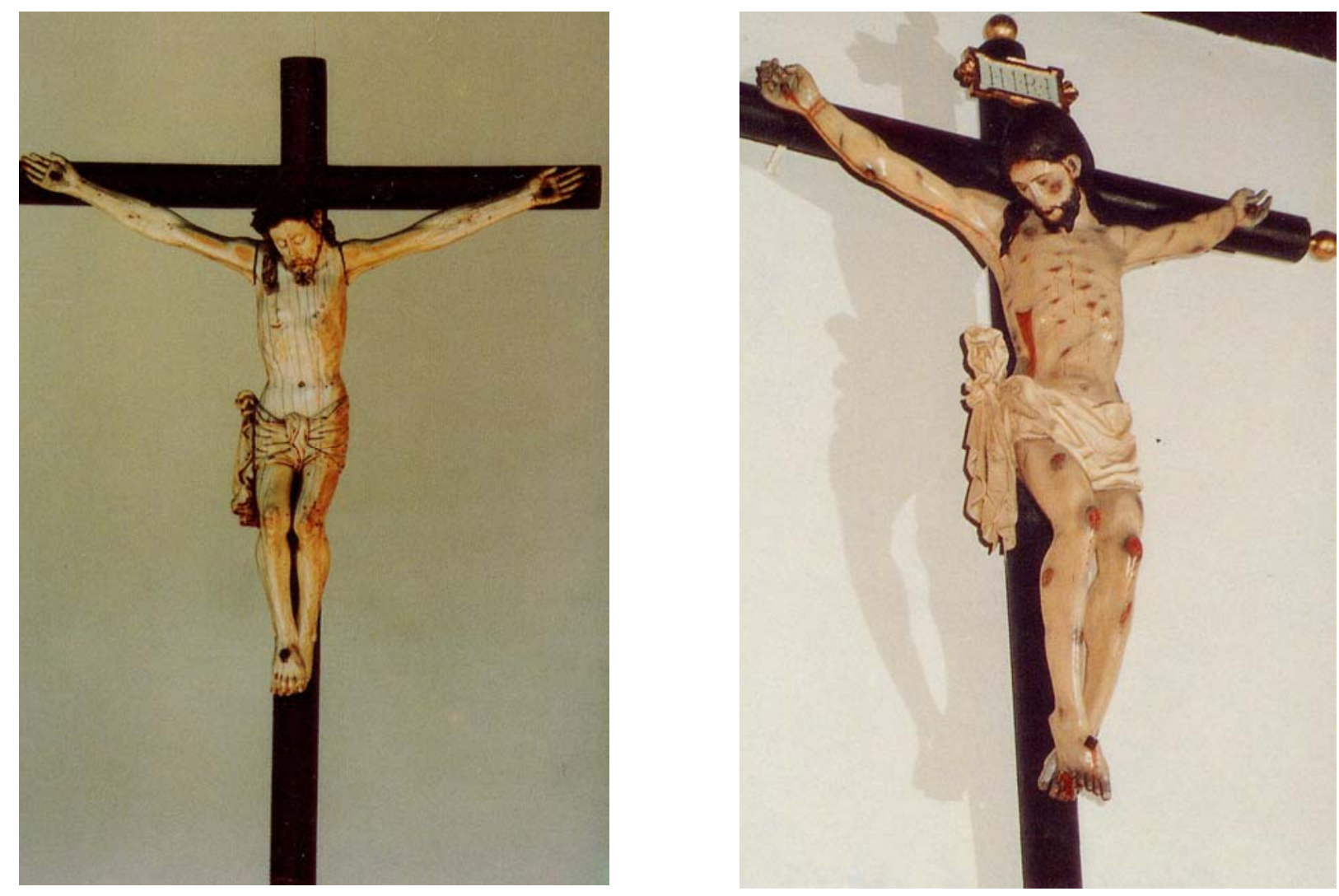

Crucificados. Monasterio de San Jerónimo.

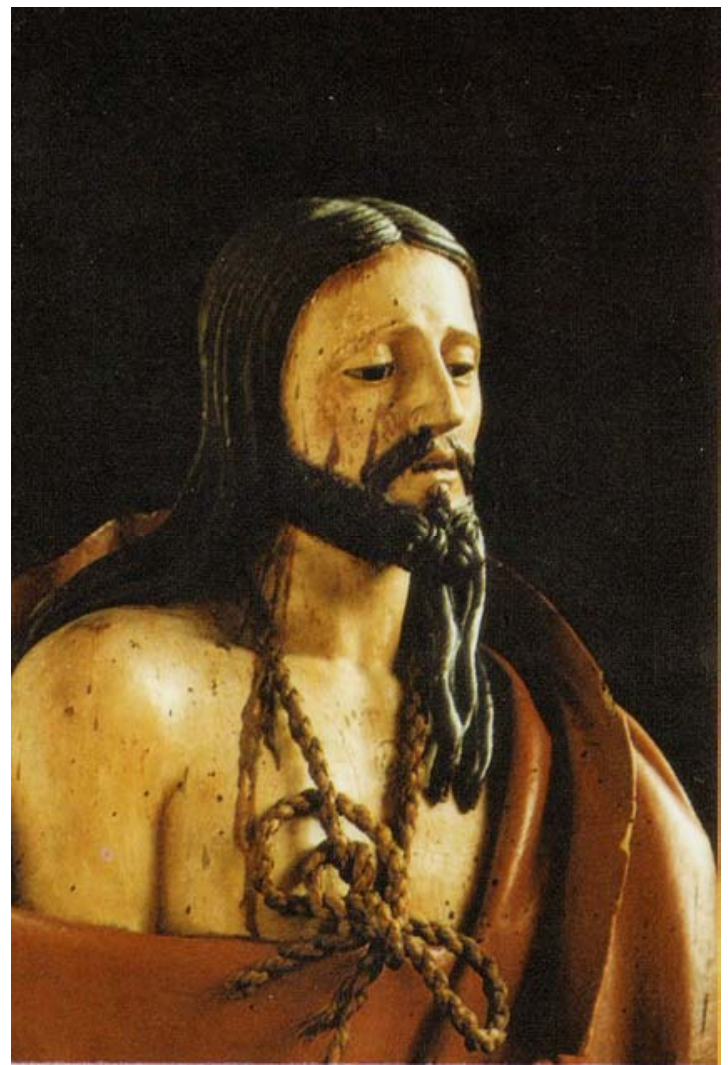

Ecce Homo. Monasterio de San Jerónimo. 
- Inmaculada Concepción. Esculturas de bulto redondo; Cano, Alonso, Seguidor de; 1700-1799; Rococó; Escuela granadina; Pan. Oro, Pigmento; Policromado, Tallado, Dorado; 45 x 16 x $15 \mathrm{~cm}$.

- Peana. Peanas; Anónimo español; 1700-1799; Rococó; Escuela española; Pan. Oro; Bruñido, Tallado, Dorado; 18 x 21 x $21 \mathrm{~cm}$.

- Taquillón. Mobiliario, Taquillones; Anónimo español; 1600-1699; Barroco; Escuela española; Metal; Ebanistería; 1,04 x 1,20 x 0,84 m.

- Crucificado. Esculturas de bulto redondo; Anónimo español; 1700-1799; Barroco; Escuela española; Pigmentos; Policromado, Tallado; 1,25 x 0,90 x 0,17 $\mathrm{m}$.

- Hachón. Hachones; Anónimo español; 1600-1699; Barroco; Escuela española; Pan. Oro, Pigmento; Tallado, Técnica de dorado; 3,50 x 1,16 x 1 m.

- Urna. Mobiliario, Urnas; Anónimo español; 1700-1799; Barroco; Escuela española; Madera, Vidrio; Repujado, Técnica de soldado (Unión); 57 x 38 x 30 cm.

- Niño Jesús. Esculturas de bulto redondo; Anónimo español; 1700-1799; Barroco; Escuela española; Pigmentos; Policromado, Tallado; 16 x 14 x 18 cm.

- La entrega de las llaves a San Pedro. Pinturas, Pinturas de caballete; Rueda, Esteban de; 1600-1699; Barroco; Escuela española; Pigmento. Aceite; Pintura al óleo; 2,10 x 1,66 m.

- Inmaculada Concepción. Pinturas, Pinturas de caballete; Ardemans, Teodoro; 1600-1699; Barroco; Escuela española; Pigmento. Aceite; Pintura al óleo $2,20 \times 1,30 \mathrm{~m}$.

- Santa Lucía. Pinturas, Pinturas de caballete; Anónimo español; 16001699; Barroco; Escuela española; Pigmento. Aceite; Pintura al óleo; 1,29 x 0,53 m.

- Marco. Marcos (Cuadros); Anónimo español; 1600-1699; Barroco; Escuela española; Pan. Oro, Pigmento; Policromado, Tallado, Dorado; 0,92 x 1,24 m.

- San Liborio. Pinturas, Pinturas de caballete; Sevilla Romero y Escalante, Juan de; 1650-1699; Barroco; Escuela granadina; Pigmento. Aceite; Pintura al óleo; 1,60 x 1,47 m.

- Ángel Custodio. Pinturas, Pinturas de caballete; Sevilla Romero y Escalante, Juan de; 1650-1699; Barroco; Escuela granadina; Pigmento. Aceite; Pintura al óleo; 1,60 x 1,47 m. 
- Marco; Ángel Custodio. Marcos (Cuadros); Anónimo español; 16501699; Barroco; Escuela granadina; Pan. Oro, Pigmento; Policromado, Tallado; 2,10 $\mathrm{x} 1,97 \mathrm{~m}$.

- San Antonio de Padua con el Niño Jesús. Pinturas, Pinturas de caballete; Sevilla Romero y Escalante, Juan de; 1650-1699; Barroco; Escuela granadina; Pigmento. Aceite; Pintura al óleo; 1,03 x 1,35 m.

- Cristo, Salvador del mundo. Pinturas, Pinturas de caballete; Anónimo flamenco; 1500-1599; Gótico; Escuela flamenca; Pigmento. Aceite; Pintura al óleo; $90 \times 66 \mathrm{~cm}$.

- Virgen orante. Pinturas, Pinturas de caballete; Anónimo flamenco; 15851599; Gótico; Escuela flamenca; Pigmento. Aceite; Pintura al óleo; 90 x 66 cm.

- Crucificado. Pinturas, Pinturas de caballete; Risueño, José; 1693-1712; Barroco; Escuela granadina; Pigmento. Aceite; Pintura al óleo; 1,88 x 1,87 m.

- Marco; Crucificado. Marcos (Cuadros); Anónimo español;1685-1714; Barroco; Escuela granadina; Pan. Oro, Pigmento; Policromado, Tallado, Dorado; $2,17 \times 2,17 \mathrm{~m}$.

- Santa Teresa de Jesús. Anónimo español; 1600-1699; Barroco; Escuela granadina; Pan. Oro, Pigmento; Estofado, Policromado, Tallado; 1,13 x 0,43 x 0,44 m.

- La Coronación de la Virgen. Bocanegra, Pedro Atanasio; 1685-1714; Barroco; Escuela granadina; Pigmento. Aceite; Pintura al óleo; 1,02 x 0,82 m.

- Marco; La Coronación de la Virgen. Anónimo español; 1685-1699; Barroco; Escuela granadina; Pan. Oro; Tallado, Técnica de dorado; 1,25 x 1,05 m.

- Inmaculada Concepción. Mena y Medrano, Pedro de; 1650-1724; Barroco; Escuela granadina; Pan. Oro, Pigmento; Estofado, Policromado, Tallado; $67 \times 24 \times 20 \mathrm{~cm}$.

- Urna; Inmaculada Concepción. Anónimo español; 1800-1899; Barroco; Escuela granadina; Bronce, Madera, Marfil; Tallado, Taracea; 1,22 × 1,08 x 0,45 $\mathrm{m}$.

- San Cornelio. Mena y Escalante, Alonso de; 1600-1624; Barroco; Escuela granadina; Pan. Oro, Pigmento; Estofado, Policromado, Tallado; 77 x 62 x $52 \mathrm{~cm}$.

- Ecce-Homo. Anónimo español; 1600-1699; Barroco; Escuela granadina; Pigmento. Aceite; Pintura al óleo; 83 x $57 \mathrm{~cm}$. 
- Marco; Ecce-homo. Marcos; Anónimo español; 1600-1699; Barroco; Escuela granadina; Pigmento; Policromado, Tallado; 1,05 x 0,81 m.

- Santa Catalina de Alejandría. Pinturas, Pinturas de caballete; Anónimo español; 1600-1799; Barroco; Escuela granadina; Pigmento. Aceite; Pintura al óleo; 1,08 x 1,08 m.

- Sagrada Familia. Pinturas, Pinturas de caballete; Anónimo español; 1600-1699; Barroco; Escuela granadina; Pigmento. Aceite; Pintura al óleo; 1,60 x $1,14 \mathrm{~m}$

- Inmaculada Concepción. Pinturas, Pinturas de caballete; Anónimo español; 1600-1699; Barroco; Escuela granadina; Pigmento. Aceite; Pintura al óleo; 1,83 x 1,39 m.

- Virgen de las Angustias. Pinturas, Pinturas de caballete; Anónimo español; 1600-1699; Barroco; Escuela granadina; Pigmento. Aceite; Pintura al óleo; 1,57 x $0,98 \mathrm{~m}$.

- Niño Jesús de gloria. Esculturas de bulto redondo; Anónimo español; 1500-1599; Manierismo; Escuela granadina; Pan. Oro, Pigmento; Estofado, Policromado, Tallado; $67 \times 25 \times 16 \mathrm{~cm}$.

- Urna; Niño Jesús de gloria. Urnas; Anónimo español; 1700-1799; Barroco; Escuela granadina; Pan. Oro; Tallado, Técnica de dorado; 1,28 x 0,95 x $0,52 \mathrm{~m}$.

- Calvario. Pinturas, Pinturas de caballete; Anónimo español; 1600-1699; Barroco; Escuela andaluza; Pigmento. Aceite; Pintura al óleo; 2,19 x 1,28 m.

- Virgen Dolorosa. Pinturas, Pinturas de caballete; Anónimo español; 1600-1699; Barroco; Escuela granadina; Pigmento. Aceite; Pintura al óleo; 1,46 x $1,03 \mathrm{~m}$.

- Crucificado. Pinturas, Pinturas de caballete; Anónimo español; 16001699; Barroco; Escuela granadina; Pigmento. Aceite; Pintura al óleo; 1,45 x 1,05 $\mathrm{m}$.

- Marco; San Juan Bautista. Marcos (Cuadros); Anónimo español; 16001799; Barroco; Escuela española; Pan. Oro; Tallado, Técnica de dorado; 2,28 x $2,06 \mathrm{~m}$.

- San Juan Bautista. Pinturas, Pinturas de caballete; Anónimo español; 1600-1699; Barroco; Escuela española; Pigmento. Aceite; Pintura al óleo: 1,88 x $1,66 \mathrm{~m}$.

- Puerta de ventanas. Ventanales; Anónimo español; 1500-1599; Gótico; Escuela española; Madera, Metal, Vidrio; Técnica de ebanistería; 1,42 x 1,33 m. 
- Puerta. Mobiliario, Puertas de cuarterones; Anónimo español; 16001699; Barroco; Escuela española; Madera, Metal; Técnica de ebanistería; 1,13 x $0,94 \mathrm{~m}$.

- Inmaculada Concepción. Pinturas, Pinturas de caballete; Bocanegra, Ambrosio Atanasio; 1690-1690; Barroco; Escuela granadina; Pigmento. Aceite; Pintura al óleo; 1,68 x 1,14 m.

- Marco; Inmaculada Concepción. Marcos (Cuadros); Anónimo español; 1690-1690; Barroco; Escuela española; Pan. Oro, Pigmento; Policromado Tallado, Técnica de dorado; 1,75 x 1,21 m.

- Mesa. Mesas, Mobiliario; Anónimo español; 1600-1699; Barroco; Escuela española; Madera; Técnica de ebanistería; 0,84 x 1,32 x 0,86 m.

- Arcón. Arcones, Mobiliario; Anónimo español; 1600-1699; Barroco; Escuela española; Madera, Metal; Técnica de ebanistería; 0,73 x 1,88 x 0,71 m.

- La Anunciación. Pinturas, Pinturas de caballete; Sevilla Romero y Escalante, Juan de; 1600-1699; Barroco; Escuela granadina; Materiales: Pigmento. Aceite; Técnicas: Pintura al óleo; 2,40 x 2,02 m.

- La Cena de Emaús. Pinturas, Pinturas de caballete; Sevilla Romero y Escalante, Juan de; 1685-1699; Barroco; Escuela granadina; Materiales: Pigmento. Aceite; $2,51 \times 2,10 \mathrm{~m}$.

- Multiplicación de los panes y los peces. Pinturas, Pinturas de caballete; Sevilla Romero y Escalante, Juan de; 1600-1699; Barroco; Escuela granadina; Materiales: Pigmento. Aceite; Técnicas: Pintura al óleo; 2,51 x 3,34 m.

- San Juan de Dios repartiendo limosna. Pinturas, Pinturas de caballete; Sevilla Romero y Escalante, Juan de; 1600-1699; Barroco; Escuela granadina; Materiales: Pigmento. Aceite; Técnicas: Pintura al óleo; 2,51 x 2,07 m.

- Marco; Santo Tomás dando limosna. Marcos (Cuadros); Sevilla Romero y Escalante, Juan de; 1600-1799; Barroco; Escuela española; Pan. Oro; Tallado, Técnica de dorado; $0,82 \times 1,01 \mathrm{~m}$.

- La Sagrada Familia comiendo. Pinturas, Pinturas de caballete; Sevilla Romero y Escalante, Juan de; 1600-1699; Barroco; Escuela granadina; Materiales: Pigmento. Aceite; Técnicas: Pintura al óleo; 2,48 x 2,07 m.

- San Juan de Dios llevando a un pobre enfermo sobre sus hombros. Pinturas, Pinturas de caballete; Sevilla Romero y Escalante, Juan de; 1600-1699; Barroco; Escuela granadina; Materiales: Pigmento. Aceite; Técnicas: Pintura al óleo; 62 × $83 \mathrm{~cm}$. 
- Santo Tomás dando limosna. Pinturas, Pinturas de caballete; Sevilla Romero y Escalante, Juan de; 1600-1699; Barroco; Escuela granadina; Materiales: Pigmento. Aceite; Técnicas: Pintura al óleo; 62 x $83 \mathrm{~cm}$.

- Ecce-Homo. Pinturas, Pinturas de caballete; Anónimo español; 16001699; Barroco; Escuela española; Pigmento. Aceite; Pintura al óleo; 1,05 x 0,85 m.

- Puerta. Mobiliario, Puertas de cuarterones; Anónimo español; 1600-1799; Barroco; Escuela española; Madera; Técnica de ebanistería; 3,90 x 2,25 m.

- Mesa. Mesas. Refectorios, Mobiliario; Anónimo español; 1500-1599; Renacimiento; Escuela española; Hierro, Madera; Forjado, Técnica de ebanistería; $0,98 \times 3,15 \times 0,62 \mathrm{~m}$.

- Mesa. Mesas. Refectorios, Mobiliario; Anónimo español; 1500-1599; Renacimiento; Escuela española; Madera; Técnica de ebanistería; 0,98 x 5,75 x $0,50 \mathrm{~m}$.

- Azulejo. Azulejo; Anónimo español; 1500-1599; Renacimiento; Escuela española; Pigmento; Cocción. Hornos, Modelado, Vidriado; 25,5 x 19,5cm.

- Azulejo. Azulejo; Anónimo español; 1500-1599; Renacimiento; Escuela española; Pigmento; Cocción. Hornos, Modelado, Vidriado; 25,5 x 19,5 cm.

- Azulejo. Azulejo; Anónimo español; 1500-1599; Renacimiento; Escuela española; Pigmento; Cocción. Hornos, Modelado, Vidriado; 25,5 x 19,5 cm.

- Tríptico de Cristo Muerto. Pinturas de caballete, Retablos. Tríptico; Cuevas; 1600-1799; Barroco; Escuela española; Pigmento. Aceite; Pintura al óleo $1,50 \times 3,20 \mathrm{~m}$.

- San Francisco de Paula; Tríptico de Cristo muerto. Pinturas, Pinturas de caballete; Cuevas; 1600-1799; Barroco; Escuela española; Pigmento. Aceite; Pintura al óleo; 1,25 x 1,02 m.

- Cristo muerto; Tríptico de Cristo muerto. Tipologías: Pinturas, Pinturas de caballete; Cuevas; 1600-1799; Barroco; Escuela española; Pigmento. Aceite; Pintura al óleo; 1,25 x 2,53 m.

- San Francisco de Asís; Tríptico de Cristo muerto. Pinturas, Pinturas de caballete; Cuevas; 1600-1799; Barroco; Escuelas: Escuela española; Pigmento. Aceite; Pintura al óleo 1,25 x 1,02 m.

- Aparición del ángel a San Pedro. Pinturas, Pinturas de caballete; Anónimo español; 1600-1699; Barroco; Escuela española; Pigmento. Aceite; Pintura al óleo 1,65 x 2,07 m. 


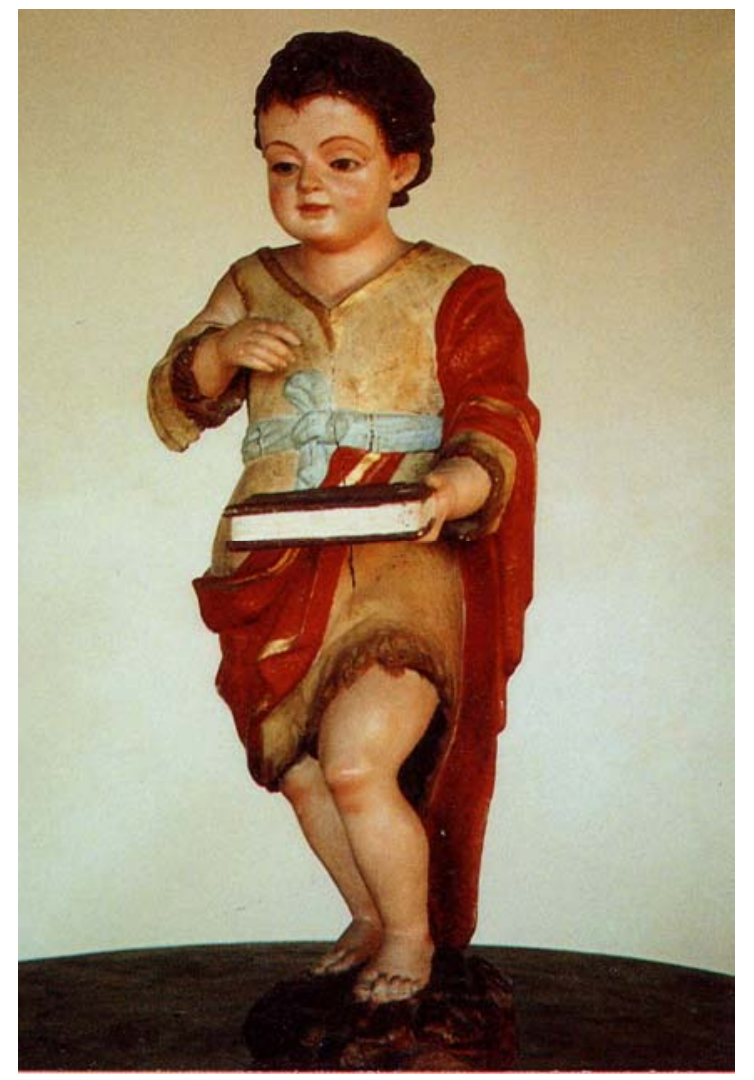

San Juan Bautista. Monasterio de San Jerónimo.

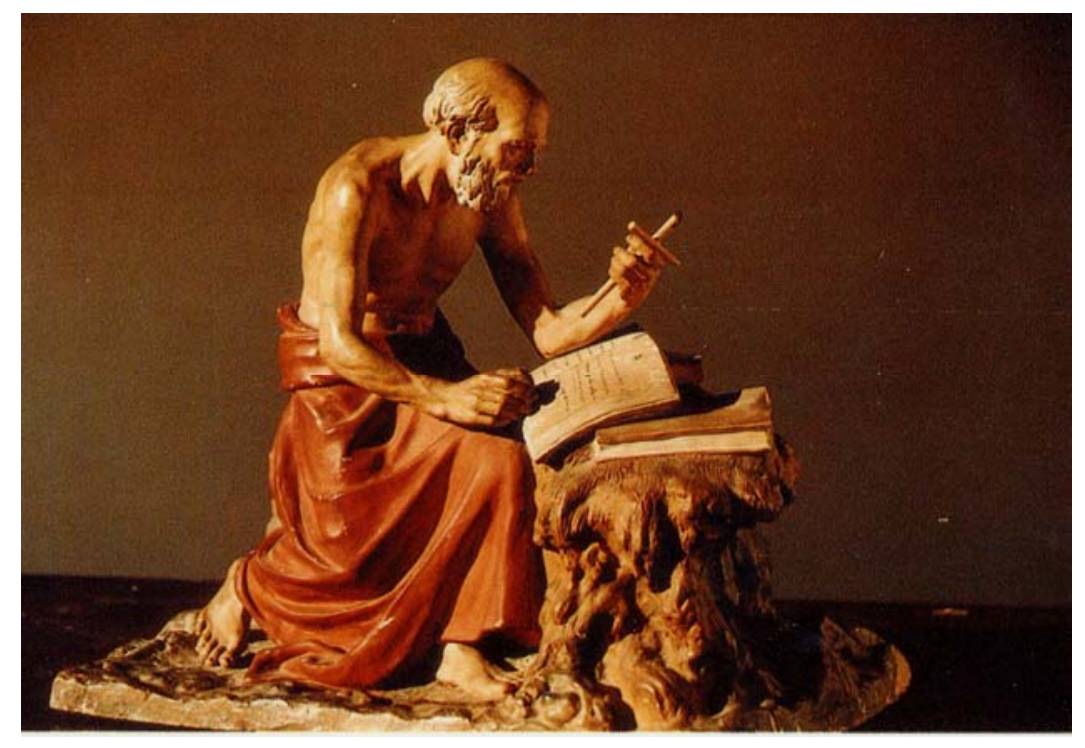

San Jerónimo. Monasterio de San Jerónimo. 
- San Jerónimo penitente. Pinturas, Pinturas de caballete; Anónimo español; 1600-1699; Barroco; Escuela española; Pigmento. Aceite; Pintura al óleo; $1,47 \times 2,08 \mathrm{~m}$.

- Virgen Dolorosa. Esculturas de busto; Anónimo granadino; 1500-1599; Renacimiento; Escuela granadina; Pigmento; Policromado, Tallado; 38 x 35 x 23 $\mathrm{cm}$.

- Urna; Virgen Dolorosa. Urnas; Anónimo español; 1600-1699; Barroco; Escuela española; Pan. Oro, Pigmento; Policromado Tallado, Técnica de dorado; $90 \times 59 \times 43 \mathrm{~cm}$.

- Ecce Homo. Esculturas de busto; Anónimo granadino; 1500-1599; Renacimiento; Escuela granadina; Pigmento; Policromado, Tallado; 44 x 40 x 23 $\mathrm{cm}$.

- Taquillón. Mobiliario, Taquillones; Anónimo español; 1600-1699; Barroco; Escuela española; Madera, Metal; Técnica de ebanistería; 1,06 x 1,21 x $0,63 \mathrm{~m}$.

-Pila lavamanos. Aguamaniles; Anónimo español; 1500-1599; Renacimiento; Escuela española; Mármol; Labrado; 2,70 x 1,85 x 0,53 m.

- Escudo; Pila lavamanos. Escudos heráldicos; Anónimo español; 15001599; Renacimiento; Escuela española; Mármol; Labrado; 74 x 58 cm

- Puerta. Mobiliario, Puertas de cuarterones; Anónimo español; 17001799; Barroco; Escuela española; Madera; Técnica de ebanistería; 3,90 x 2,25 m.

- Puerta de ventanas. Mobiliario, Ventanales; Anónimo español; 16001699; Barroco; Escuela española; Madera, Metal, Vidrio; Técnica de ebanistería; $2,45 \times 1,97 \mathrm{~m}$.

- Retablo del Calvario. Retablos; Anónimo español; 1700-1799; Barroco; Escuela española; Pan. Oro; Ensamble, Tallado, Técnica de dorado; 3,18 x 3,10 x $0,75 \mathrm{~m}$.

- Mesa de altar; Retablo del Calvario. Altares fijos; Anónimo español; 1500-1599; Renacimiento; Escuela española; Mármol; Cincelado, Labrado, Pulido; 1,02 × 2,33 m.

- Sagrario; Retablo del Calvario. Sagrarios (Objetos); Anónimo español; 1500-1599; Renacimiento; Escuela española; Pan. Oro; Tallado, Técnica de dorado; 80 × $58 \times 38 \mathrm{~cm}$.

- Santo; Retablo del Calvario. Esculturas de bulto redondo; Anónimo español; 1600-1699; Barroco; Escuela española; Pan. Oro, Pigmento; Policromado, Tallado, Técnica de dorado; 1,39 × $0,60 \times 0,40 \mathrm{~m}$. 
- Santo; Retablo del Calvario. Esculturas de bulto redondo; Anónimo español; 1600-1699; Barroco; Escuela española; Pan. Oro, Pigmento; Policromado, Tallado, Técnica de dorado; $1,41 \times 0,66$ x 0,45 m.

- San Juan Bautista; Retablo del Calvario. Esculturas de bulto redondo; Anónimo español; 1600-1699; Barroco; Escuela española; Pan. Oro, Pigmento; Policromado, Tallado, Técnica de dorado; $72 \times 26$ × $26 \mathrm{~cm}$.

- Cristo atado a la columna. Pinturas, Pinturas de caballete; Anónimo español; 1500-1699; Manierismo; Escuela española; Pigmento. Aceite; Pintura al óleo; 1,43 x 1,17 m.

- Virgen de la Soledad. Pinturas, Pinturas de caballete; Anónimo español; 1600-1699; Barroco; Escuela española; Pigmento. Aceite; Pintura al óleo 1,21 x $0,60 \mathrm{~m}$.

- Cristo con la cruz a cuestas. Pinturas, Pinturas de caballete; Anónimo español; 1600-1699; Barroco; Escuela española; Pigmento. Aceite; Pintura al óleo $1,21 \times 0,60 \mathrm{~m}$.

- Muerte de San Juan de Dios. Pinturas, Pinturas de caballete; Anónimo español; 1600-1699; Barroco; Escuela española; Pigmento. Aceite; Pintura al óleo; $1,25 \times 0,83 \mathrm{~m}$.

- Marco; Muerte de San Juan de Dios. Marcos (Cuadros), Mobiliario; Anónimo español; 1600-1699; Barroco; Escuela granadina; Pan. Oro, Pigmento; Policromado, Tallado, Técnica de dorado; 1,50 x 1,10 m.

- Ecce-Homo. Esculturas de bulto redondo; Anónimo español; 1700-1799; Barroco Escuela española; Pigmento; Policromado, Tallado; 1,70 x 0,60 x 0,45 m.

- Cruz. Anónimo español; 1600-1699; Barroco; Escuela española; Piedra; Labrado; $62 \times 23 \mathrm{~cm}$.

- Banco. Bancos (Asientos). Mobiliario; Anónimo español; 1600-1699; Barroco; Escuela española; Madera; Técnica de ebanistería; 0,93 x 2,85 x 0,44 m.

- Campana. Campanas; Anónimo español; 1400-1599; Gótico; Escuela española; Bronce, Hierro; Fundición; 28 x 25 cm.

- Vidriera. Vidrieras; Anónimo español; 1500-1599; Gótico; Escuela española; Pigmento, Plomo, Vidrio; Ensamble, Policromado, Soplado de vidrio; $1,15 \mathrm{~m}$.

- Lámpara. Lámparas; Anónimo español; 1600-1699; Barroco; Escuela española; Metal; Fundición; 58 x 20 cm. 
- Puerta. Mobiliario, Puertas de cuarterones; Anónimo español; 16001699; Barroco; Escuela española; Madera; Técnica de ebanistería; 1,62 x 1,43 m.

- Banco. Bancos (Asientos)., Mobiliario; Anónimo español; 1600-1699; Barroco; Escuela española; Madera; Técnica de ebanistería; 0,80 x 2,31 x 0,45 m.

- Banco. Bancos (Asientos). Mobiliario; Anónimo español; 1600-1699; Barroco; Escuela española; Madera; Técnica de ebanistería; 0,80 x 2,43 x 0,49 m.

- Banco. Bancos (Asientos). Mobiliario; Anónimo español; 1600-1699; Barroco; Escuela española; Madera; Técnica de ebanistería; 0,88 x 1,93 x 0,46 m.

- Farol. Faroles; Anónimo español; 1600-1699; Barroco; Escuela española; Hierro, Vidrio; Forjado, Repujado; 1,55 x 0,67 m.

- Puerta. Mobiliario, Puertas; Anónimo español; 1500-1599; Renacimiento; Escuela española; Madera, Metal; Técnica de ebanistería; 3,40 x $2,10 \mathrm{~m}$.

- Virgen con el Niño. Esculturas de bulto redondo; Anónimo español; 1600-1699; Barroco; Escuela española; Mármol; Labrado, Pulido; 60 x 30 x 27 $\mathrm{cm}$.

- Reja. Rejas; Anónimo español; 1600-1699; Barroco; Escuela española; Hierro; Cincelado, Forjado; 1,69 x 3,45 m.

- Reja. Rejas; Anónimo español; 1600-1699; Barroco; Escuela española; Hierro; Cincelado, Forjado, Repujado; 2,70 x 1,73 m.

- Reja. Rejas; Anónimo español; 1700-1799; Barroco; Escuela española; Hierro; Forjado, Repujado; 1,69 x 2,74 m.

- Reja. Rejas; Anónimo español; 1700-1799; Barroco; Escuela española; Hierro; Forjado, Repujado; 1,69 x 2,74 m.

- Reja. Rejas; Anónimo español; 1600-1699; Barroco; Escuela española; Hierro; Forjado; 1,22 x 2,27 x 0,68 m.

- Reja. Rejas; Anónimo español; 1700-1799; Barroco; Escuela española; Hierro; Forjado, Repujado; 0,88 x 2,67 m.

- Sillón frailero. Mobiliario, Sillones frailero; Anónimo español; 16001699; Barroco; Escuela española; Anea, Cuero, Madera; Técnica de ebanistería; $99 \times 69 \times 58 \mathrm{~cm}$.

- Frontal de altar. Frontales de altar; Anónimo italiano; 1500-1599; Renacimiento; Escuela italiana; Mármol; Labrado, Pulido; 1,06 x 3,48 m. 
- Puerta. Mobiliario; Puertas; Anónimo español; 1500-1599; Renacimiento; Escuela española; Madera, Metal, Técnica de ebanistería; 2,90 x $2,22 \mathrm{~m}$

- Puerta. Mobiliario; Puertas; Puertas de cuarterones; Anónimo español 1700-1799; Barroco Escuela española; Madera Técnica de ebanistería; 3,32 x 1,88 m.

- Puerta. Mobiliario; Puertas; Puertas de cuarterones; Anónimo español 1700-1799; Barroco; Escuela española; Madera Técnica de ebanistería; 3,22 x 1,78 $\mathrm{m}$.

- Banco. Tipologías: Bancos (Asientos). Iglesias, Mobiliario, Anónimo español; 1600-1699; Barroco Escuela española, Madera; Técnica de ebanistería; $1,01 \times 2,68 \times 0,57 \mathrm{~m}$.

- Banco. Bancos (Asientos). Iglesias, Mobiliario; Anónimo español; 16001699; Barroco; Escuela española; Madera; Técnica de ebanistería; 1,21 x 2,52 m.

- Santa Ana. Pinturas, Pinturas de caballete; Bocanegra, Pedro Atanasio; 1600-1699; Barroco; Escuela española; Pigmento. Aceite; Pintura al óleo; 2 x 1,20 m.

- San Joaquin. Pinturas, Pinturas de caballete; Bocanegra, Pedro Atanasio; 1600-1699; Barroco; Escuela española; Pigmento. Aceite; Pintura al óleo; 2 x 1,20 $\mathrm{m}$.

- Inmaculada Concepción. Pinturas, Pinturas de caballete; Cano, Alonso, Seguidor de; 1600-1799; Barroco; Escuela española; Pigmento. Aceite; Pintura al óleo; 2,30 x 1,50 m.

-Reja. Rejas; Anónimo español; 1800-1899; Neoclasicismo; Escuela española; Hierro; Forjado; 1,30 x 2,30 m.

-Jesús con la cruz a cuestas ayudado por el Cirineo. Pinturas, Pinturas de caballete; Anónimo español; 1600-1699; Barroco; Escuela española; Jesús ayudado por un cirineo; Pigmento. Aceite; Pintura al óleo 1,60 x 1,40 m.

-San Juan Evangelista. Esculturas de bulto redondo; Siloé, Diego de; 15001599; Renacimiento; Escuela española; San Juan Evangelista; Piedra, Estucado, Policromado; $1,51 \times 1,02 \times 0,67 \mathrm{~m}$.

- San Marcos. Esculturas de bulto redondo; Siloé, Diego de; 1500-1599; Renacimiento; Escuela española; San Marcos; Piedra; Estucado, Policromado; $1,52 \times 0,99 \times 0,58 \mathrm{~m}$. 
- San Lucas. Esculturas de bulto redondo; Siloé, Diego de; 1500-1599; Renacimiento; Escuela española; San Lucas; Piedra; Estucado, Policromado; 0,52 $\mathrm{x} 1 \mathrm{x} 0,60 \mathrm{~m}$.

- San Mateo. Esculturas de bulto redondo; Siloé, Diego de 1500-1599; Renacimiento; Escuela española; San Mateo (Evangelista); Piedra; Estucado, Policromado; 1,56 x 1,01 m.

- Escudo de la familia Fernández de Córdoba. Pinturas, Vidrieras; Vergara, Arnao de; 1500-1599; Renacimiento Escuelas: Escuela española; Pigmento, Plomo, Vidrio; Ensamble, Policromado, Soplado de vidrio; 2,90 x 2,90 m.

- Escudo de la ciudad de Granada. Pinturas, Vidrieras; Vergara, Arnao de; 1500-1599; Renacimiento; Escuela española; Pigmento, Plomo, Vidrio; Ensamble, Policromado, Soplado de vidrio; $2,90 \mathrm{~m}$.

- Escudo de la ciudad de Granada. Pinturas, Vidrieras; Vergara, Arnao de; 1500-1599; Renacimiento; Escuela española; Pigmento, Plomo, Vidrio; Ensamble, Policromado, Soplado de vidrio; 2,30 x 2,30 m.

- Escudo. Pinturas, Vidrieras; Vergara, Arnao de; 1500-1599; Renacimiento; Escuela española; Pigmento, Plomo, Vidrio; Ensamble, Policromado, Soplado de vidrio; $2,90 \mathrm{~m}$.

- Escudo de la ciudad de Granada. Pinturas, Vidrieras; Vergara, Arnao de; 1500-1599; Renacimiento; Escuela española; Pigmento, Plomo, Vidrio; Ensamble, Policromado, Soplado de vidrio; 2,90 m.

- Escudo de Fray Hernando de Talavera. Pinturas, Vidrieras; Vergara, Arnao de; 1500-1599; Renacimiento; Escuela española; Pigmento, Plomo, Vidrio; Ensamble, Policromado, Soplado de vidrio; 2,30 x 2,20 m.

- Escudo de Fray Hernado de Talavera. Pinturas, Pinturas de caballete; Anónimo español; 1600-1699; Barroco; Escuela española Pigmento. Aceite; Pintura al óleo; 0,75 x 1,08 m.

- Banco. Bancos (Asientos). Mobiliario; Anónimo español; 1696-1696; Barroco Escuela española; Madera; Técnica de ebanistería; 1,02 x 2,61 x 0,66 m.

- Mesa. Mesas, Mobiliario; Anónimo español; 1600-1699; Barroco; Escuela española; Madera; Técnica de ebanistería; 0,96 x 1,55 x 0,92 m.

- Mesa. Mesas, Mobiliario; Anónimo español; 1600-1699; Barroco; Escuela española; Madera; Técnica de ebanistería; 0,87 x 1,35 x 0,91 m. 
- Cristo con la cruz a cuestas. Pinturas, Pinturas de caballete; Anónimo español; 1600-1699; Barroco; Escuela española; Pigmento. Aceite; Pintura al óleo ; $58 \times 79 \mathrm{~cm}$.

- Marco; Cristo con la cruz a cuestas. Marcos (Cuadros); Anónimo español; 1700-1799; Rococó; Escuela española; Pan. Oro; Bruñido, Tallado, Técnica de dorado; $1,08 \times 1,20 \mathrm{~m}$.

- Puerta. Mobiliario, Puertas de cuarterones; Anónimo español; 16001699; Barroco; Escuela española; Madera; Técnica de ebanistería; 2,90 x 1,46 m.

- Puerta. Mobiliario, Puertas de cuarterones; Anónimo español; 16001699; Barroco; Escuela española; Madera; Técnica de ebanistería; 2,51 x 1,42 m.

- Puerta. Mobiliario, Puertas de cuarterones; Anónimo español; 15001599-, Renacimiento; Escuela española; Madera, Metal; Técnica de ebanistería; $3,38 \times 2,32 \mathrm{~m}$.

- Puerta. Mobiliario, Puertas de cuarterones; Anónimo español; 16001699; Barroco; Escuela española; Madera; Técnica de ebanistería; 2,78 x 1,68 m.

- Consola. Consolas, Mobiliario; Anónimo español; 1770-1799; Barroco; Escuela española; Pan. Oro; Policromado, Tallado, Técnica de dorado; 0,90 x 1,12 $\mathrm{x} 0,39 \mathrm{~m}$.

- Silla. Mobiliario, Sillas; Anónimo español; 1600-1699; Barroco; Escuela española; Cuero, Madera, Metal; Técnica de ebanistería; 97 x 43 x 36 cm.

- Mesa. Mesas, Mobiliario; Anónimo español; 1600-1699; Barroco; Escuela española; Madera; Técnica de ebanistería; 0,85 x 2,10 x 0,83 m.

- Marco. Marcos (Cuadros); Anónimo español; 1750-1899; Barroco; Escuela española; Pan. Oro; Bruñido, Tallado, Técnica de dorado; 52 x 43,5 cm.

- Reja. Rejas; Anónimo español; 1700-1799; Barroco; Escuela española; Hierro; Cincelado, Forjado, Repujado; 2,50 x 4,98 m.

- Peana. Peanas; Anónimo español; 1500-1599; Renacimiento; Escuela española; Madera; Tallado; 0,30 x 1,19 x 0,30 m.

- Banco. Bancos (Asientos). Mobiliario; Anónimo español; 1600-1699; Barroco; Escuela española; Madera; Técnica de ebanistería; 1,20 x 2,18 x 0,80 m.

-Reja. Rejas; Anónimo español; 1700-1799; Barroco; Escuela española Hierro; Forjado, Repujado; 1,30 x 2,56 m. 
- Candelero. Candeleros; Anónimo español; 1600-1699; Barroco; Escuela española; Pigmento; Policromado, Tallado, Torneado; 34 x 14 x 14 cm.

- Candelero. Candeleros; Anónimo español; 1600-1699; Barroco; Escuela española; Pigmento; Policromado, Tallado, Torneado; 42 x 17 x $17 \mathrm{~cm}$.

- Retablo de Nuestra Señora de los Siete Dolores. Retablos. Capillas de iglesias; Anónimo español; 1800-1800; Barroco; Escuela española; Pan. Oro, Pigmento; Policromado, Tallado, Técnica de dorado; 3,10 x 3 x 0,23 m.

- Buen Pastor; Retablo de Nuestra Señora de los Dolores. Retablos. Capillas de iglesias; Anónimo español; 1700-1700; Barroco; Escuela española; Pigmento. Aceite; Pintura al óleo; 40 x $27 \mathrm{~cm}$.

- Nuestra Señora de los Siete Dolores; Retablo de Nuestra Señora de los Siete Dolores; Pinturas, Pinturas de caballete; Anónimo español; 1700-1700; Barroco; Escuela española; Pigmento; Pintura al óleo; 1,70 x 1,22 m.

- Aparición de un ángel a un San Pedro. Pinturas, Pinturas de caballete; Anónimo español; 1700-1700; Barroco; Escuela española; Pigmento. Aceite; Pintura al óleo; 30 x $45 \mathrm{~cm}$.

- Frontal de altar. Frontales de altar; Anónimo español; 1600-1799; Barroco; Escuela española; Mármol; Labrado, Pulido; 1,03 x 2,21 m.

- Hachón. Hachones; Anónimo español; 1700-1799; Barroco; Escuela española; Pan. Oro, Pigmento; Policromado, Tallado, Técnica de dorado; 1,57 x $0,64 \times 0,55 \mathrm{~m}$.

- La colocación de Cristo en el sepulcro. Pinturas, Pinturas de caballete; Anónimo español; 1500-1599; Renacimiento; Escuela española; Pigmento. Aceite; Pintura al óleo; $1,43 \times 0,93 \mathrm{~m}$.

- Calvario. Pinturas, Pinturas de caballete; Anónimo español; 1600-1699; Barroco; Escuela española; Pigmento. Aceite; Pintura al óleo; 2,16 x 1,63 m.

- Lámpara. Lámparas; Anónimo español; 1600-1699; Barroco; Escuela española; Metal; Fundición; 1,02 x 0,43 x 0,43 m.

- Reja. Rejas; Anónimo español; 1700-1799; Barroco; Escuela española; Hierro, Mármol; Forjado, Repujado, Técnica de dorado; 1,52 x 5,15 m.

- Frontal de altar. Frontales de altar; Anónimo español; 1600-1699; Barroco; Escuela española; Mármol; Labrado, Pulido; 1,02 x 2,90 m. 


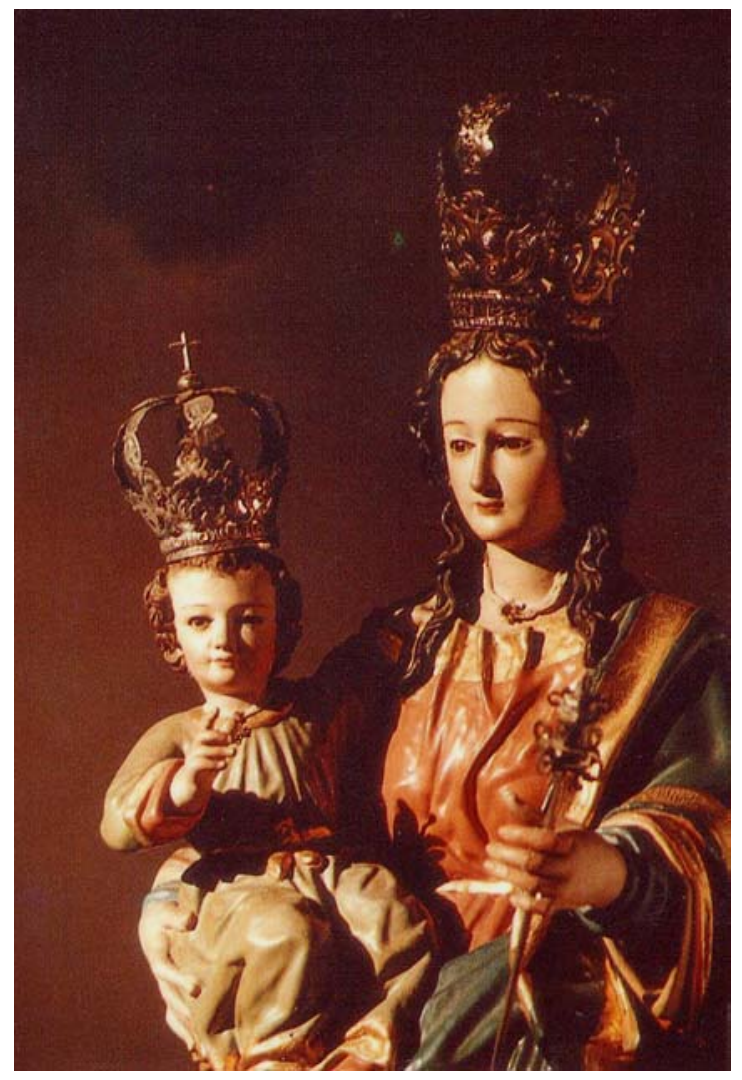

Virgen con el Niño.

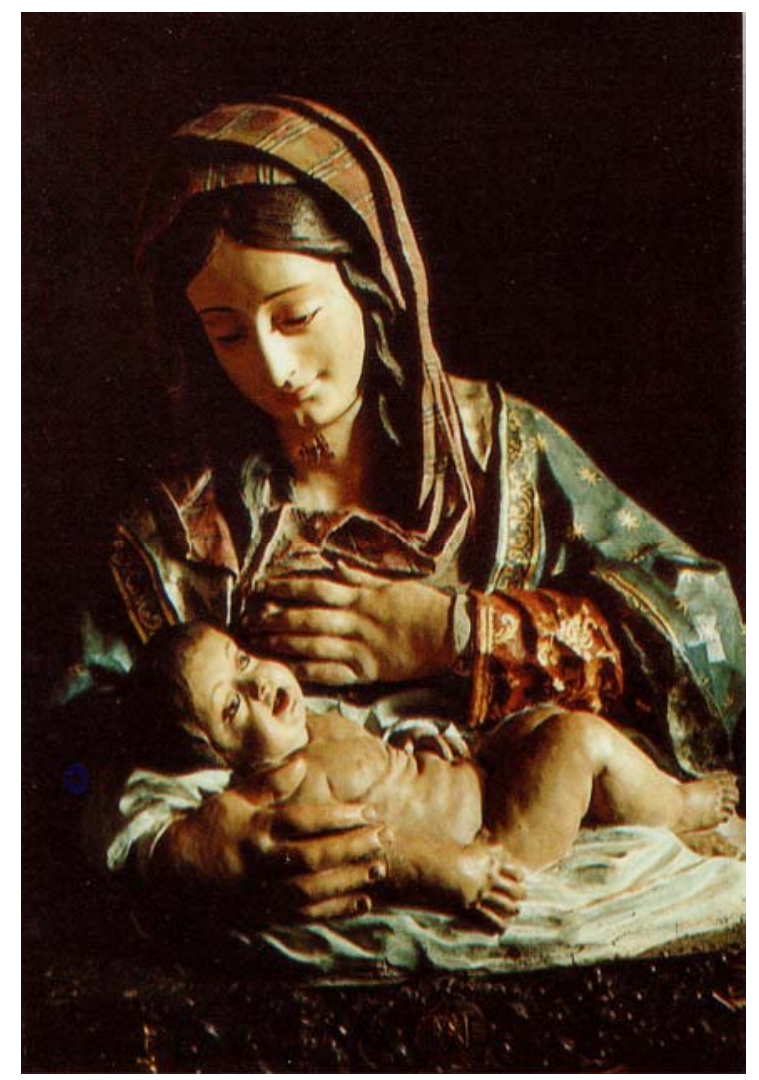

Virgen de Belén.

Monasterio de San Jerónimo.

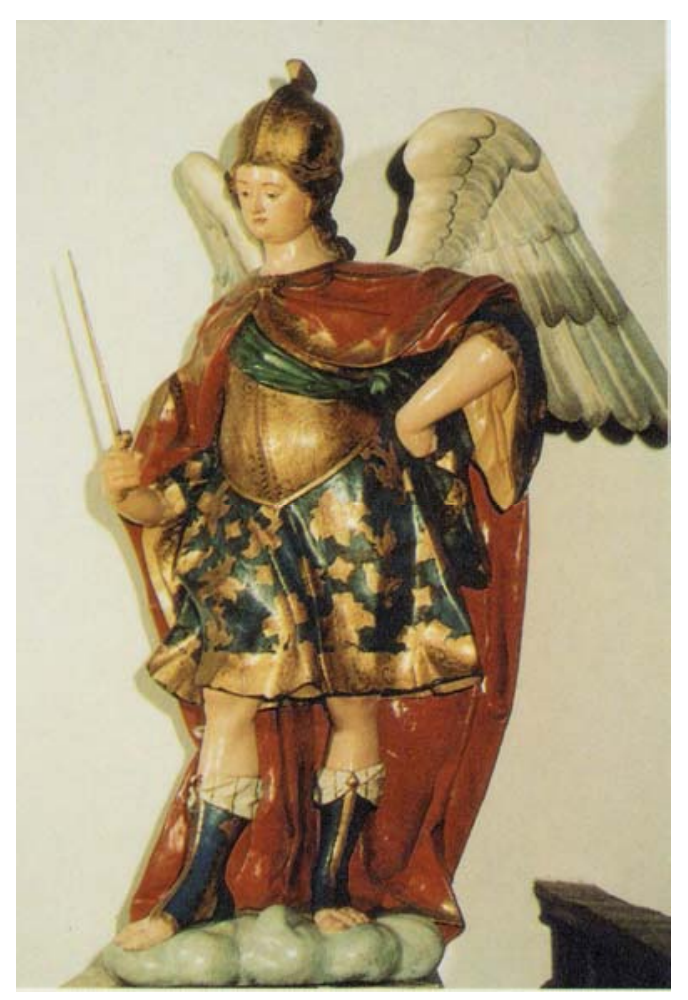

San Miguel.

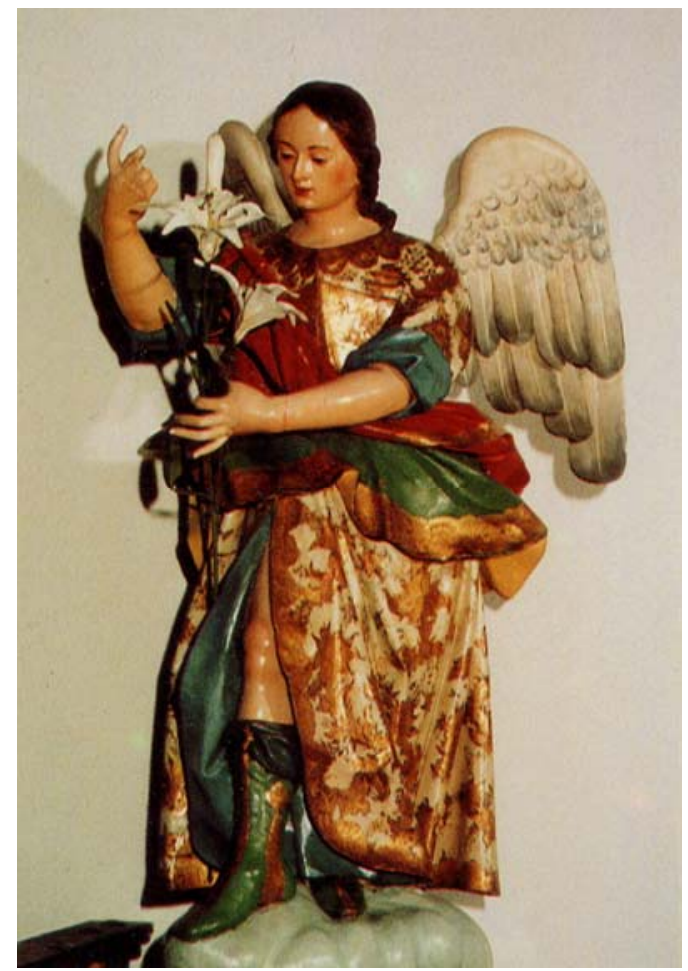

San Gabriel.

Monasterio de San Jerónimo. 
- Consola. Consolas, Mobiliario; Anónimo español; 1700-1799; Barroco; Escuela española; Madera, Mármol; Labrado, Técnica de ebanistería; 0,92 x 1,34 x $0,64 \mathrm{~m}$.

- Consola. Consolas, Mobiliario; Anónimo español; 1700-1799; Barroco; Escuela española; Madera, Mármol; Labrado, Técnica de ebanistería; 0,87 x 1,40 x $0,62 \mathrm{~m}$.

- Reja. Rejas; Anónimo español; 1700-1799; Barroco; Escuela española; Pan. Oro; Forjado, Repujado, Técnica de dorado; 1,28 x 5,18 m.

- Frontal de altar. Frontales de altar; Anónimo español; 1600-1699; Barroco; Escuela española; Mármol; Pulido; 1,02 x 2,35 m.

- Peana. Peanas; Anónimo español; 1700-1799; Rococó; Escuela española; Pan. Oro; Calado, Tallado, Técnica de dorado; 22 x 49 x $42 \mathrm{~cm}$.

- Candelero. Candeleros; Anónimo español; 1600-1699; Barroco; Escuela española; Pigmento; Policromado, Tallado; 70 x $16 \mathrm{~cm}$.

- Frontal de altar. Frontales de altar; Anónimo español; 1600-1699; Barroco; Escuela española; Mármol; Pulido, Tallado; 1,01 x 2,54 m.

- Sitial. Mobiliario, Sitiales; Anónimo español; 1600-1699; Barroco; Escuela española; Madera; Técnica de ebanistería; 1,07 x 0,87 x 0,57 m.

- Hachón. Hachones; Anónimo español; 1600-1699; Barroco; Escuela española; Pan. Oro, Pigmento; Policromado, Tallado, Técnica de dorado; $1,30 \mathrm{x}$ $0,55 \times 0,49 \mathrm{~m}$.

- Mesa. Mesas, Mobiliario; Anónimo español; 1700-1799; Barroco; Escuela española; Madera; Técnica de ebanistería; 0,89 x 1,27 x 0,76 m.

- Reclinatorio. Mobiliario, Reclinatorios; Anónimo español; 1600-1799; Barroco; Escuela española; Madera, Terciopelo; Técnica de ebanistería; 90 x 60 x $49 \mathrm{~cm}$.

- Reja. Rejas; Anónimo español; 1500-1599; Renacimiento; Escuela española; Pan. Oro; Cincelado, Forjado, Repujado; 3,28 x 5 m.

- Reja. Rejas; Anónimo español; 1700-1799; Barroco; Escuela española; Pan. Oro; Forjado, Repujado, Técnica de dorado; 1,57 x 5,20 m.

- Candelero. Candeleros. Altares; Anónimo español; 1500-1599; Renacimiento; Escuela española; Pigmento; Tallado, Técnica de dorado, Torneado; $48 \times 15 \times 15 \mathrm{~cm}$. 
- Consola. Consolas, Mobiliario; Anónimo español; 1700-1799; Barroco; Escuela española; Madera; Técnica de ebanistería; 0,89 x 1,17 x 0,52 m.

- Consola. Consolas, Mobiliario; Anónimo español; 1700-1799; Barroco; Escuela española; Madera; Técnica de ebanistería; 0,84 x 1,14 x 0,60 m.

- Reclinatorio. Mobiliario, Reclinatorios; Anónimo español; 1685-1699; Barroco; Escuela española; Madera; Técnica de ebanistería; 87 x 57 x $50 \mathrm{~cm}$.

- Confesionario. Confesionarios, Mobiliario; Anónimo español; 16001799; Barroco; Escuela española; Madera; Técnica de ebanistería; 2 x 0,72 x 0,95 $\mathrm{m}$.

- Reja. Rejas; Anónimo español; 1700-1799; Barroco; Escuela española; Pigmento; Forjado, Repujado, Técnica de dorado; 1,02 x 2,46 m.

- Frontal de altar. Frontales de altar; Anónimo español; 1800-1899; Neoclasicismo; Escuela española; Mármol; Cincelado, Labrado, Pulido; 1,30 x $5,20 \mathrm{~m}$.

- Reloj. Mobiliario, Relojes de péndulo; Anónimo español; 1600-1699; Barroco; Escuela española; Madera, Metal; Repujado, Técnica de ebanistería; 2,37 x $0,42 \times 0,20 \mathrm{~m}$.

- Puerta. Mobiliario, Puertas, Puertas de cuarterones; Anónimo español; 1600-1699; Barroco; Escuela española; Madera; Técnica de ebanistería; 2,60 x $1,38 \mathrm{~m}$.

- Banco. Bancos (Asientos)., Mobiliario; Anónimo español; 1600-1699; Barroco; Escuela española; Madera; Técnica de ebanistería; Medidas

- Silla - reclinatorio. Mobiliario, Sillas; Anónimo español; 1700-1799; Barroco; Escuela española; Madera, Terciopelo; Técnica de ebanistería; 88 x 50 x $45 \mathrm{~cm}$.

- Banco. Bancos (Asientos). Mobiliario; Anónimo español; 1600-1699; Barroco; Escuela española; Madera; Técnica de ebanistería; 0,42 x 1,45 x 0,29 m.

- Armario. Armarios, Mobiliario; Anónimo español; 1700-1799; Barroco; Escuela española; Madera, Metal; Técnica de ebanistería; 1,74 x 0,68 x 0,57 m.

- Atril. Atriles, Mobiliario; Anónimo español; 1600-1699; Barroco; Escuela española; Madera; Técnica de ebanistería; 1,23 x 0,44 x 0,45 m.

- Banco. Bancos (Asientos) Mobiliario; Anónimo español; 1600-1699; Barroco; Escuela española; Madera; Técnica de ebanistería; 0,42 x 2,57 x 0,29 m. 
- Consola. Consolas, Mobiliario; Anónimo español; 1600-1699; Barroco; Escuela española; Madera; Técnica de ebanistería; 85 x 69 x 39 cm.

- Banqueta. Banquetas, Mobiliario; Anónimo español; 1600-1699; Barroco; Escuela española; Madera; Técnica de ebanistería; 42 x 42 × 29 cm.

- Pila. Pilares (Soportes verticales). Fuentes; Anónimo español; 15651565; Renacimiento; Escuela española; Mármol; Labrado; 3,10 × 3,90 x 1,18 m.

- Fuente. Fuente (Utensilio) Anónimo español; 1600-1699; Barroco; Escuela española; Mármol; Labrado; 0,99 x 2,80 m.

- Pila. Pilares (Soportes verticales). Fuentes; Anónimo español; 16001699; Barroco; Escuela española; Piedra; Labrado; 1,07 x 0,97 x 1,14 m.

- Pila. Pilares (Soportes verticales). Fuentes; Anónimo español; 15001599; Renacimiento; Escuela española; Mármol; Labrado; 0,41 x 1,05 x 0,65 m.

- Pila. Pilares (Soportes verticales). Fuentes; Anónimo español; 18001899; Neoclasicismo; Escuela española; Mármol; Labrado; 0,50 x 0,66 x 1,19 m.

- Pila. Pilares (Soportes verticales). Fuentes; Anónimo español; 18001899; Neoclasicismo; Escuela española; Mármol; Labrado; 0,64 x 1,82 x 0,84 m.

- Pila. Pilares (Soportes verticales). Fuentes; Anónimo español; 16001699; Barroco; Escuela española; Mármol; Labrado; 2,60 x 0,96 m.

- Pila. Pilares (Soportes verticales). Fuentes; Anónimo español; 15001699; Manierismo; Escuela española; Mármol; Labrado; 1,17 x 1,15 m.

- Brocal. Brocales de pozo; Anónimo español; 1700-1799; Barroco; Escuela española; Mármol; 66 x $65 \mathrm{~cm}$.

- Brocal. Brocales de pozo; Anónimo español; 1700-1799; Barroco; Escuela española; Mármol; Labrado; 83 x 61 x $61 \mathrm{~cm}$.

- Brocal. Brocales de pozo; Anónimo español; 1700-1799; Barroco; Escuela española; Metal, Piedra; Labrado; 2,10 x 1,15 m.

- Brocal. Brocales de pozo; Anónimo español; 1700-1799; Barroco; Escuela española; Mármol; Labrado; 1,04 x 0,84 x 0,67 m.

- La Anunciación. Pinturas, Vidrieras; Vergara, Arnao de; 1500-1599; Renacimiento; Escuela española; Pigmento, Plomo, Vidrio; Ensamble, Policromado, Soplado de vidrio; 3,20 x 1,80 m. 

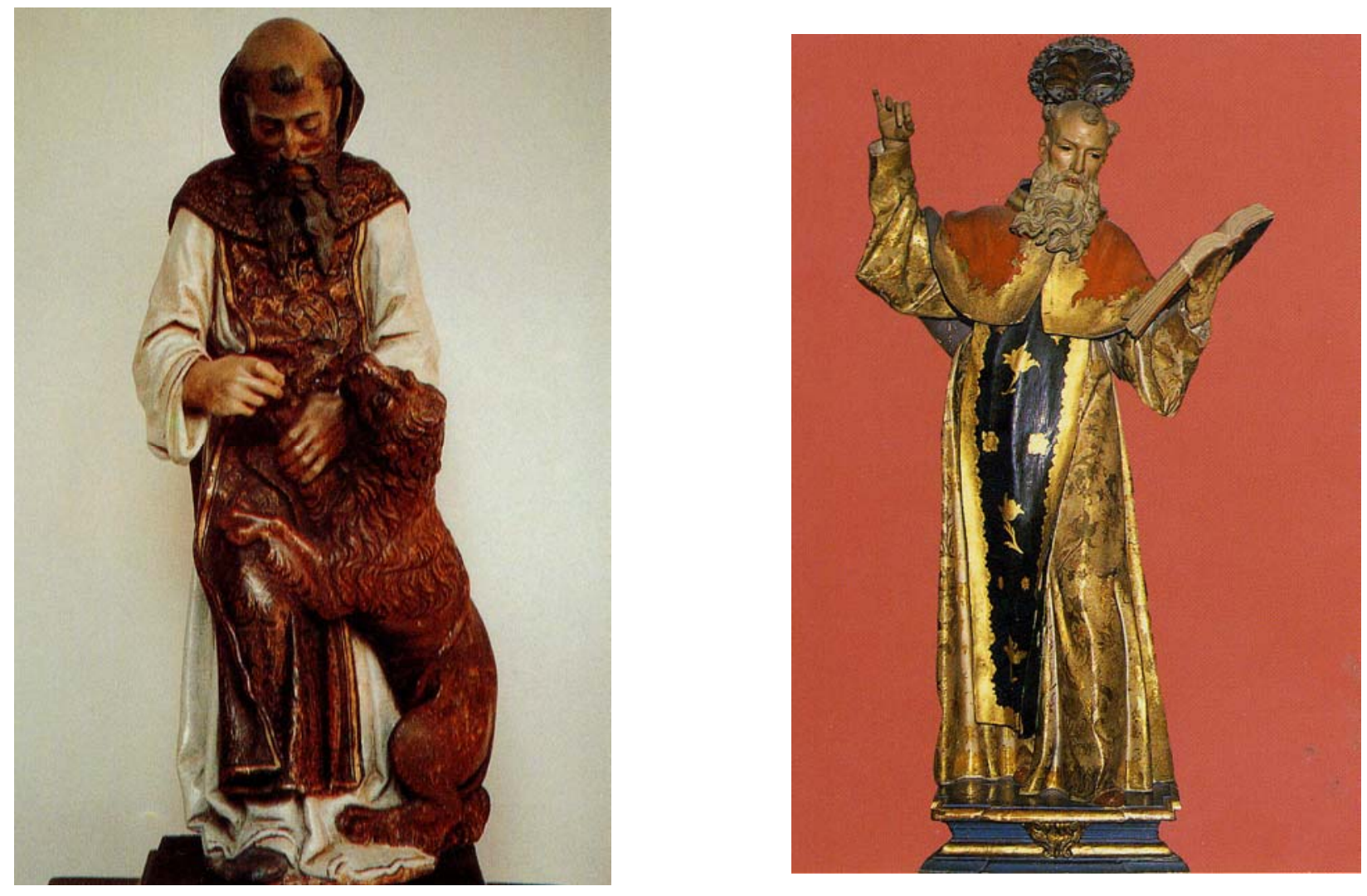

Dos esculturas de San Jerónimo.

Monasterio de San Jerónimo

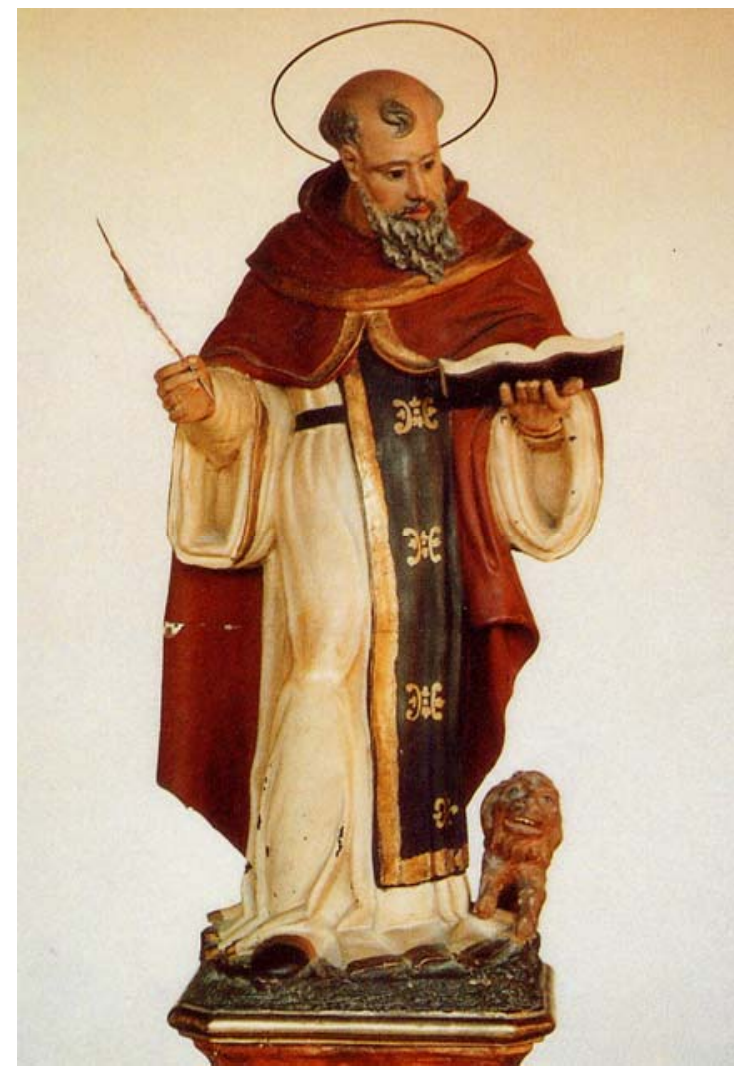

San Jerónimo.

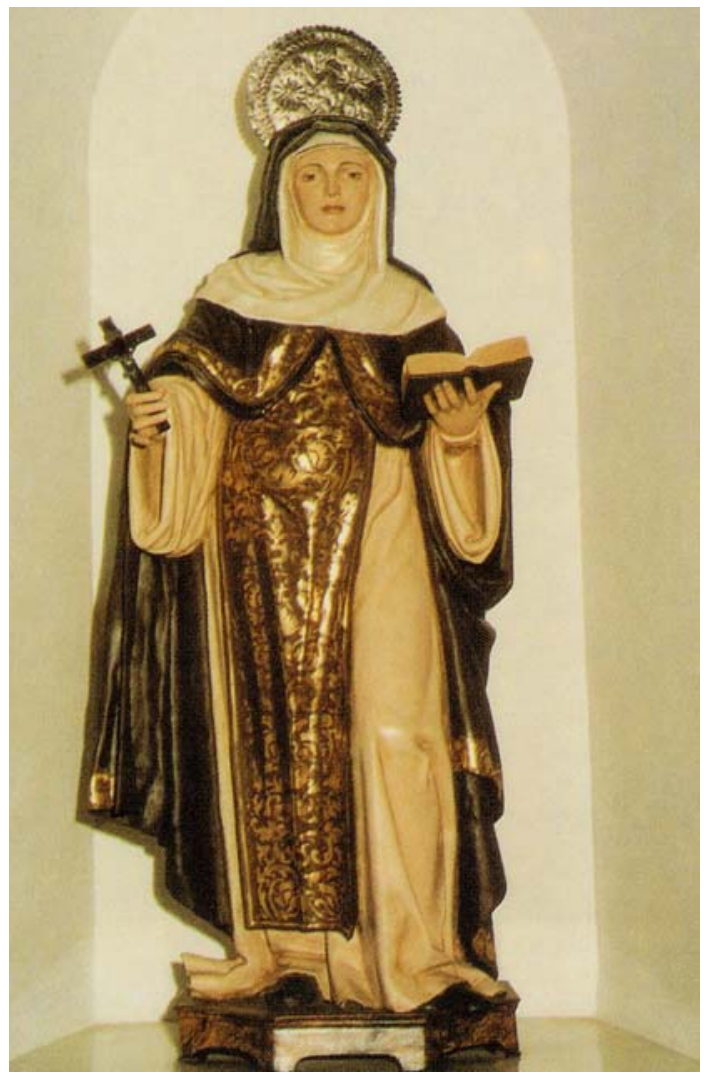

Santa Paula.

Monasterio de San Jerónimo. 
- Los Desposorios de la Virgen. Pinturas, Vidrieras; Vergara, Arnao de; 1500-1599; Renacimiento; Escuela española; Pigmento, Plomo, Vidrio; Ensamble, Policromado, Soplado de vidrio; 3,20 x 1,80 m.

- La Visitación. Pinturas, Vidrieras; Vergara, Arnao de; 1500-1599; Renacimiento; Escuela española; Pigmento, Plomo, Vidrio; Ensamble, Policromado, Soplado de vidrio; 3,20 x 1,80 m.

- La Adoración de los magos. Pinturas, Vidrieras; Vergara, Arnao de; 1500-1599; Renacimiento; Escuela española; Pigmento, Plomo, Vidrio; Ensamble, Policromado, Soplado de vidrio; 3,20 x 1,80 m.

- Nacimiento de Jesús. Pinturas, Vidrieras; Vergara, Arnao de; 1500-1599; Renacimiento; Escuela española; Pigmento, Plomo, Vidrio; Ensamble, Policromado, Soplado de vidrio; 3,20 x 1,80 m.

- La Circuncisión. Pinturas, Vidrieras; Vergara, Arnao de; 1500-1599; Renacimiento; Escuela española; Pigmento, Plomo, Vidrio; Ensamble, Policromado, Soplado de vidrio; 3,20 x 1,80 m.

- Frontal de altar. Frontales de altar; Anónimo español; 1500-1599; Renacimiento; Escuela española; Pan. Oro, Pigmento; Policromado, Tallado, Técnica de dorado; $0,95 \times 1,32 \mathrm{~m}$.

- Puerta. Mobiliario, Puertas de cuarterones; Anónimo español; 16001699; Barroco; Escuela española; Madera, Metal; Técnica de ebanistería; 2,54 x $1,34 \times 0,5 \mathrm{~m}$.

- Puerta. Mobiliario, Puertas de cuarterones; Anónimo español; 16001699; Barroco; Escuela española; Madera; Técnica de ebanistería; 1,83 x 1,10 m.

- Puerta. Mobiliario, Puertas, Puertas de cuarterones; Anónimo español; 1500-1599; Renacimiento ; Escuela española; Hierro, Madera; Forjado, Repujado, Técnica de ebanistería; 3,30 × 2,08 x 0,10 m.

- Puerta. Mobiliario, Puertas, Puertas de cuarterones; Anónimo español; 1500-1599; Renacimiento ; Escuela española; Hierro, Madera; Forjado, Repujado, Técnica de ebanistería; 2,75 x 1,20 x 0,10 m.

- Pila. Pilas de agua bendita. Adosado; Anónimo español; 1600-1699; Barroco; Escuela española; Mármol; Labrado, Pulido; 85 x 68 x 53 cm.

- Inmaculada Concepción. Esculturas de bulto redondo; Mena, Alonso de, Seguidor de; 1600-1699; Barroco; Escuela granadina; Mármol; Labrado, Pulido $2,31 \times 1,02 \times 0,70 \mathrm{~m}$.

- Virgen de las Angustias. Esculturas de bulto redondo; Anónimo español 
1500-1599; Renacimiento; Escuela española; Madera, Metal, Piedra; Tallado; 1,10 $\mathrm{x} 1 \times 0,30 \mathrm{~m}$.

- San Jerónimo penitente. Esculturas de bulto redondo; Díaz de Navarrete, Martín, Orea, Pedro de; 1590-1590; Renacimiento; Escuela española; Piedra; Labrado; $2,19 \times 1,35 \times 0,60 \mathrm{~m}$.

- Puerta. Mobiliario, Puertas; Anónimo español; 1500-1599; Renacimiento; Escuela española; Madera, Metal; Técnica de ebanistería; 4,33 x $2,78 \mathrm{~m}$.

- Puerta. Mobiliario, Puertas; Anónimo español; 1500-1599; Renacimiento; Escuela española; Madera, Metal; Técnica de ebanistería; 5,80 x $2,85 \mathrm{~m}$

- Puerta. Mobiliario, Puertas; Anónimo español; 1500-1599; Renacimiento Escuela española; Hierro, Madera; Forjado, Técnica de ebanistería; 3,95 x 2,70 m.

- Cancel. Canceles, Mobiliario; Anónimo español; 1768-1768; Barroco; Escuela española; Madera; Técnica de ebanistería; 6,03 x 4,10 x 0,88 m.

- Cancel. Canceles, Mobiliario; Anónimo español; 1600-1600; Barroco Escuela español; Madera; Técnica de ebanistería; 6,44 x 4,68 x 1,88 m.

- Escudo de Fray Hernández de Talavera; Cancel. Escudos heráldicos; Anónimo español; 1600-1699; Barroco; Escuela española; Madera; Tallado; 1,20 x $0,78 \mathrm{~m}$.

- Escudo; Cancel. Escudos heráldicos; Anónimo español; 1600-1699; Barroco; Escuela española; Madera; Tallado; 1,20 x 0,78 m.

No obstante, cabe la posibilidad de que existan otras piezas en el Monasterio de San Jerónimo que por diversas circunstancias no fueron incluidas en este Inventario realizado por el I.A.P.H.

También señalar la existencia de otras piezas que se encuentran en el Monasterio pero que no pertenecen a la Orden, sino a la Cofradía que tiene por sede la iglesia de San Jerónimo, es decir, la Pontificia y Real Cofradía y Hermandad de Nuestra Señora de la Soledad y Descendimiento del Señor y por lo tanto, no se han considerado a la hora de redactar este proyecto. 
V. PROGRAMA DE CONSERVACIÓN PREVENTIVA. 


\section{PROGRAMA DE CONSERVACIÓN PREVENTIVA}

\section{Determinación de las necesidades según el volumen y la naturaleza de la colección.}

Nunca hay que olvidar que una de las principales funciones que debe desarrollar un museo, y por tanto nuestro Monasterio, es la de conservar sus colecciones. Pero...qué es conservar, podemos definirlo como toda actividad humana directa o indirecta encaminada a aumentar la esperanza de vida de la colecciones intactas y de las deterioradas, pero no debemos preguntamos cómo vamos a conservar sino para qué conservar, pues porque somos los responsables de un patrimonio histórico y artístico de gran valor, al que debemos proteger para que pueda seguir difundiendo el mensaje que contiene y para que pueda ser disfrutado por las futuras generaciones.

Para conseguirlo, en primer lugar, hay que conocer y prestar atención a los factores que pueden causar el posible deterioro de esos bienes, tanto naturales como humanos, entre esos factores podemos señalar la temperatura, la humedad, iluminación, contaminación atmosférica, plagas, incorrecta manipulación, etcétera. En segundo lugar, hay que tomar las medidas adecuadas para poder controlarlos. Este conjunto de acciones es lo que podría denominarse como conservación preventiva.

En el siguiente esquema podemos ver cuales son las causas, naturales y humanas, que pueden provocar un deterioro de los objetos.

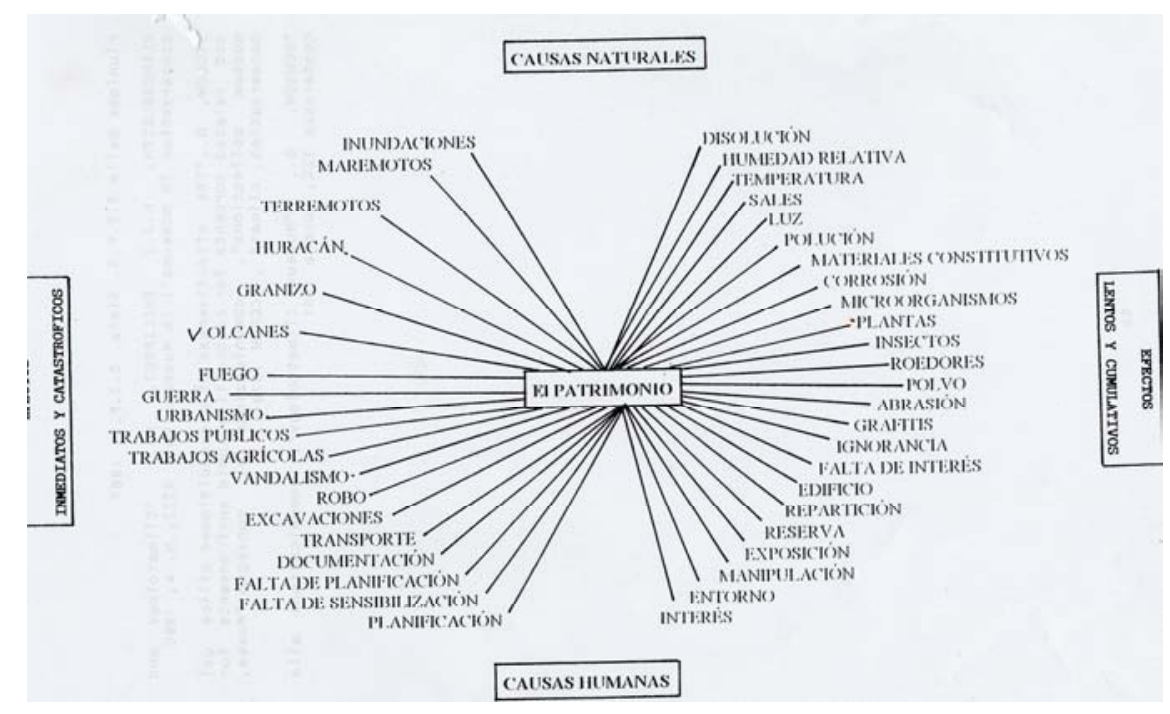

Para poder establecer u $\mathrm{n}$ buen sistema de conservación preventiva, hay que conocer la colección, es decir, qué materiales son los que hay que proteger, en el 
Monasterio de San Jerónimo nos encontramos aparte de la piedra, sobre todo con pintura de caballete (óleo sobre lienzo) y escultura de bulto redondo (madera estofada y policromada y marfil) que se componen de los siguientes materiales: madera, tela, aceite, oro, pigmentos y marfil.

No debemos olvidar el proceso de degradación que cualquier objeto sufre a lo largo de su vida, además el patrimonio mueble del que nos ocuparemos ha establecido un equilibrio físico y químico con el medio en el que se encuentra, con el Monasterio. Hay que procurar, por tanto, que no se produzca ninguna variación en el medio, que no se produzca la ruptura de ese equilibrio, ya que el objeto al intentar adaptarse a esas nuevas condiciones, podría reaccionar causándole efectos destructivos.

En un principio, no pensamos en instalar un sistema de Climatización, debido al carácter histórico del edificio. Pero si este proyecto de musealización y puesta en valor se llevará a cabo, el número de personas que visitaría el Monasterio aumentaría mucho, por lo que las condiciones de humedad y temperatura sufrirían un cambio brusco que afectaría de forma negativa a la colección y al propio edificio, por lo que si vamos a instalar un sistema de climatización que establezca unos parámetros determinados de temperatura, humedad, etcétera, con el objeto de crear un microclima dentro del Monasterio adecuado para la conservación del mismo y del patrimonio mueble que alberga.

Intentaremos conseguir un sistema racional de conservación preventiva, es decir, mantener y controlar unas condiciones ambientales lo más constantes posibles, así como diagnosticar todos los peligros inherentes al medio. Todo gracias, a unas técnicas adecuadas a los objetos y al edificio que pretendemos conservar.

Además de conocer los condicionantes medioambientales, será necesario conocer la climatología del lugar en el que se encuentra ubicado el Monasterio, ya que las variaciones climáticas que se producen en el exterior van a repercutir en el interior del edificio, así como las oscilaciones entre el día y la noche, entre los distintos meses del año, o los cambios producidos por una gran afluencia de visitantes en un determinado momento. Por supuesto, sin dejar de lado a la naturaleza de las colecciones y a la confortabilidad de los visitantes.

\section{Control de las constantes ambientales.}

Para poder controlar las constantes ambientales hay que tener en cuenta tres factores: la temperatura, la humedad relativa y las partículas en suspensión.

\section{- La temperatura.}

Es la variable que nos indica el nivel calorífico de un cuerpo, la haremos disminuir si extraemos calor del cuerpo, y la haremos aumentar si le aportamos calor. 
Realmente la temperatura, no es uno de los principales problemas a la hora de la conservación de un bien cultural, ya que no le afecta de una forma directa, mientras esta se mantenga estable dentro de unos parámetros, sino que afecta a la obra negativamente de una forma indirecta, es decir, el mayor problema que presenta es su relación con la humedad relativa, así a mayor temperatura menos humedad relativa y a menor temperatura la humedad relativa aumenta, por ejemplo, un descenso brusco de $6^{\circ}$ e elevará la humedad relativa en un $20 \%$.

\section{- La humedad relativa.}

La cantidad de vapor de agua que hay en el ambiente afecta a las personas e influye en la estabilidad de los materiales que forman las obras de arte.

La humedad relativa es la relación existente entre el peso de agua contenido en un volumen de aire dado y el peso máximo que este volumen de aire dado podría contener a la misma temperatura.

La humedad en un edificio puede provenir del exterior, o del interior, por la limpieza de los suelos, por la condensación sobre las paredes frías, por respiración y transpiración de los visitantes, así el ser humano produce hasta 80 gramos de vapor de agua en una hora, esto depende también de la época del año, así en invierno, la persona lleva más ropa, por 10 que el pasaje es más lento.

Los efectos que la humedad relativa puede tener en los objetos orgánicos son:

- Aumento de humedad, si absorben humedad del ambiente, aumentan de volumen y se favorece el desarrollo de hongos y moho.

- Descenso de humedad, si ceden humedad al ambiente, se resecan y se contraen.

\section{- Las partículas en suspensión.}

El aire se compone de una mezcla de diferentes gases, así nitrógeno, oxígeno, vapor de agua y gas carbónico, pero también contiene una serie de impurezas que pueden dañar los objetos. Para que exista una buena conservación es necesario que el aire tenga la mayor pureza posible.

Los componentes de la atmósfera que más nos interesa controlar son:

- Vapor de agua, puede causar un deterioro en las obras por lo que es necesario controlar y estabilizar la humead relativa del ambiente.

- El oxígeno, puede producir alteraciones químicas, fotooxidación, en los materiales orgánicos. 
- El anhídrido sulfuroso, se origina por la combustión del carbón y de los derivados del petróleo, que ante una atmósfera húmeda se transforma en un ácido que luego se convierte en unas gotas de agua que provocan ciertas alteraciones, así el picado de barnices o la corrosión de los soportes de tela en los cuadros.

\section{- ¿Cómo vamos a controlarlas?}

Instalaremos un sistema de climatización que nos permita reproducir un ambiente artificial en las salas que permita combinar el confort de la personas que se encuentren en el Monasterio, bien como visitantes o bien como trabajadores, con las condiciones necesarias para la perfecta conservación del edificio y de las obras que en él se conservan.

La instalación será llevada a la práctica por un técnico especialista, que trabajara junto con el técnico encargado de las colecciones. Para el diseño se tendrán en cuenta:

- Los siguientes criterios: ambientales.

- Zonificación de los espacios según los usos y las condiciones

- Asegurar el control de humedad, temperatura y distribución de aire en las salas de exposición y almacén de colecciones.

- Elección de los sistemas de producción de energía de acuerdo con los consumos previstos y el ahorro energético.

- Integración de las máquinas de aire acondicionado dentro del edificio, tanto las interiores como las exteriores.

- Integración de los conductos de distribución de aire.

- Las bases de diseño, son las condiciones de temperatura y humedad del exterior y de los espacios interiores, así:

\begin{tabular}{|l|r|r|}
\hline ZON & TEMPERATURA & \multicolumn{1}{|c|}{ HUMEDAD } \\
\hline Salas exposiciones & $20^{\circ} \pm 2^{\circ} \mathrm{C}$ & $50 \%$ \\
\hline Almacén obras de arte & $20^{\circ} \pm 2^{\circ} \mathrm{C}$ & $50 \%$ \\
\hline $\begin{array}{l}\text { Vestíbulo, zonas de } \\
\text { circulación. }\end{array}$ & $20^{\circ} \pm 2^{\circ} \mathrm{C}$ & Confort \\
\hline Biblioteca, Oficinas & $21^{\circ} 2500$ & Confort \\
\hline $\begin{array}{l}\text { Sala de instalaciones, } \\
\text { máquinas, etc. }\end{array}$ & Sin controlar \\
\hline
\end{tabular}


- Filtración de aire, el aire que se toma del exterior ha de pasar previamente por las climatizadoras, existiendo diversos filtros según la calidad del aire final.

- Ocupación, las densidades máximas de ocupación que se deben tomar para cada zona para el cálculo de climatización son:

\begin{tabular}{|l|r|}
\hline \multicolumn{1}{|c|}{ ZONA } & DENSIDAD \\
\hline Sala de exposiciones & $2 \mathrm{~m}^{2}$ por persona \\
\hline Vestíbulo, zona de circulación & $5 \mathrm{~m}^{2}$ por persona \\
\hline Oficinas & $10 \mathrm{~m}^{2}$ por persona \\
\hline
\end{tabular}

- Aire exterior, para que el aire se renueve es necesario introducir aire del exterior, pero previamente debe pasar por las climatizadoras para que tenga la temperatura y humedad adecuadas. La cantidad de aire a introducir en las salas se calculará en función del número de personas que se haya calculado en el punto anterior para cada zona, y será la siguiente:

\begin{tabular}{|l|r|}
\hline \multicolumn{1}{|c|}{ ZONA } & AIRE \\
\hline Sala de exposiciones & 4 litros/ segundo/ persona \\
\hline Vestíbulo y zona de circulación & 7 litros/ segundo/ persona \\
\hline Oficinas & 12 litros/ segundo/ persona \\
\hline
\end{tabular}

- Climatizadoras, son las máquinas de producción del aire acondicionado, que se sitúan en el interior del edificio. A ellas, llegan unas tuberías con agua fría y caliente que han producido las máquinas que se situarán en el exterior. De las climatizadoras salen los conductos que llevan el aire a cada una de las salas del edificio y a ellas vuelven otros conductos de retorno con el aire que ya ha circulado por las salas. Las climatizadoras preparan el aire con las condiciones de temperatura y humedad que hemos prefijado y además lo limpian filtrándolo.

Los climatizadores se forman por la unión de distintos elementos que se van acoplando unos con otros. Así llevarán filtro de aire, batería de agua fría, batería de agua caliente, humidificador y un motor que impulsa el aire. Un sistema de control hará que el aire salga con las condiciones requeridas. Otro control consistirá en que el aire que cogen del exterior deje de entrar cuando las condiciones son desfavorables, como cuando está lloviendo, y otro control es aquel que reduce el aire que se suministra por la noche.

- Producción de calor y frío, las bombas de calor y las enfriadoras producen agua fría y caliente mediante consumo de energía, y este agua se lleva a las climatizadoras, se deberán situar al aire libre necesariamente. Como producen ruido y son antiestéticas se deberán aislar y ocultarlas a la vista en lo posible.

- La climatización de las salas de exposiciones, un tema muy importante es la distribución del aire acondicionado y de su retorno ya que condiciona estéticamente el aspecto de la sala. Pero aparte de las condiciones estéticas, muy 
importantes, están las condiciones técnicas que necesitan una disposición correcta de los difusores de aire en relación con el retorno para que el aire se distribuya por toda la sala, sin crear corrientes molestas para el visitante o dejar zonas sin ventilar.

- Controles automáticos, Se podrá instalar un Sistema de Gestión Automático SGA, que controle la climatización, las instalaciones eléctricas, el encendido / apagado del alumbrado, la climatización, las instalaciones contra incendios, etcétera. Se compone de una Unidad Central de Proceso CPU, y otras subestaciones repartidas por zonas y unidas a través de una red de comunicaciones. Las subestaciones controlarán digitalmente las funciones de los diversos equipos y estarán preparadas para mantener el control incluso si el procesador central o la red fallaran.

El sistema de gestión automático conectará y desconectará los equipos de acuerdo con la programación temporal prevista. Así, las salas de exposiciones y el almacén estarán acondicionados las 24 horas y el resto no, dependiendo del horario del uso.

Cada una de las salas de exposiciones tendrá una sonda de temperatura y de humedad montada en la pared que enviará los datos lija unidad central de proceso de la zona, así si el aire que llega al climatizador está seco se humidificará y viceversa.

Muchas instalaciones y aparatos de climatización generan ruido, por lo que todas las instalaciones deberán estar aisladas acústicamente, teniendo en cuenta que el límite de ruido en museos de $45 \mathrm{~dB}$.

Pero, a pesar de tener instalado un sistema automático de climatización y control, no hay que despreocuparse, el técnico encargado de las colecciones debe llevar un control diario del estado del edificio y de las colecciones pues la máquina puede fallar y la colección puede destruirse en poco tiempo, podemos perder por un error lo que se ha conservado durante siglos.

Se inspeccionaran todos los fondos expuestos en el Monasterio, una vez al mes, como mínimo. Esta inspección consistirá en recorrer todas las dependencias observando, con detenimiento, los objetos allí expuestos para detectar si el nivel de polvo es excesivo o si aparece alguna señal de degradación o ataque biológico. No será necesario utilizar ningún instrumento especial, así una lupa, ya que si existiera la más ligera sospecha de que estuviera sucediendo algo, el objeto se trasladará al taller de restauración, donde será sometida a un examen más exhaustivo.

También es muy importante instruir al personal que realiza las labores de mantenimiento, vigilancia o guía, sobre todos los problemas que pueden presentar las obras, así ataque biológico, cambio de color, de tamaño, sustracción, etc., para que puedan avisar al conservador o al técnico responsable de las colecciones. 


\section{- Plan de prevención y control de un ataque microbiológico.}

Incluimos ahora una serie de normas que deberemos seguir para prevenir posibles deterioros en los objetos, seguiremos las que da Isabel García Fernández.

Estableceremos una serie de normas, cuyo seguimiento nos ayudará a prevenir una posible plaga de hongos $^{56}$ :

- Mantener la humedad relativa por debajo del 65\%.

- Revisar y registrar la humedad dentro del museo con el propósito de detectar las áreas con humedades donde pudieran florecer los hongos.

-Los muros exteriores recibirán especial atención, ya que cerca de estos se suele registrar una humedad alta. Nunca colocaremos o almacenaremos ningún objeto directamente sobre el muro.

- Los estantes interiores, armarios y vitrinas se alzarán al menos $10 \mathrm{~cm}$ sobre el suelo.

- Se examinarán las colecciones regularmente para detectar el crecimiento de hongos, especialmente en época de lluvia y subida de temperatura (primavera-verano).

- Mantener una circulación de aire adecuada en todas las zonas.

- Mantener las colecciones limpias y sin polvo ya que el polvo y la suciedad contienen esporas de hongos y nutrientes que favorecen su crecimiento en materiales normalmente inertes, como el plástico o el cristal.

Las precauciones que tomaremos para evitar la entrada en el edificio de roedores y otros mamíferos pequeños ${ }^{57}$ serán:

- Mantener la comida fuera del monasterio.

- Mantener el área de servicio limpia.

- Eliminar las fuentes de agua, reparando las tuberías que goteen. Prevenir la formación de condensación en tuberías frías, instalando aislamiento para ellas.

- Asegurarse de que las puertas y las ventanas están bien cerradas.

- Comprobar todos los respiraderos y rejillas de ventilación, cubrir las aberturas con rejillas galvanizadas (con una trama de $6 \mathrm{~mm}$ ).

${ }_{56}^{56}$ García Fernández, I. M. [1999], p. 269-270.

${ }^{57}$ García Fernández, I. M. [1999], p.274. 
- Mantener las áreas de almacén despejadas y ordenadas e inspeccionarlas frecuentemente. Los estantes y armarios deben montarse a una altura mínima del suelo de $10 \mathrm{~cm}$. del suelo para permitir la limpieza y la inspección.

En cuanto a una posible plaga de insectos ${ }^{58}$, aplicaremos las siguientes medidas preventivas:

- Realizar un examen cuidadoso de los objetos que conforman la colección del monasterio. Los objetos que lleguen se inspeccionarán nada más entrar, y el resto se examinará de forma periódica.

- Mantener unas medidas sanitarias efectivas así: limpieza regular del monasterio, evitando la acumulación de polvo y basura (ésta última se contendrá en recipientes apropiados), la comida y bebida estarán prohibidas, fuera del área designada.

- Examinar el entorno del edificio, y el edificio en sí, documentando su estado, prestando especial atención a la presencia de aberturas y grietas en los muros y al estado de los cerramientos de las ventanas y puertas. También se inspeccionarán las tuberías, los conductos de aire y los sanitarios.

- Controlar las condiciones climáticas manteniendo un clima constante, evitando niveles extremos de temperatura y humedad, propiciando a su vez una ventilación adecuada, ya que una ventilación pobre es uno de los factores determinantes para la aparición de insectos.

- Controlar las fuentes de luz ricas en rayos ultravioletas, ya que pueden servir de alimento o hábitat a ciertas plagas.

\footnotetext{
${ }^{58}$ García Fernández, I.M. [1999], p. 277-278.
} 


\section{Control de iluminación.}

La luz, "es el agente físico que hace visibles los objetos" $"$, degrada los bienes culturales, por lo que es necesario controlarla por encima de criterios estéticos y funcionales que dejen a un lado de conservación. La luz es una parte de la radiación electromagnética acompañada de radiaciones no visibles que debe ser controlada, este control debe efectuarse sobre:

- El nivel de iluminación.

- Tiempo de exposición.

Teniendo en cuenta que los efectos fotoquímicos de una fuente luminosa sobre un objeto siempre son acumulativos, y que el nivel de iluminación y el tiempo de exposición se relacionan inversamente para obtener el mismo grado de efecto perjudicial.

"En cualquier caso hay que tener presente que todo objeto expuesto siempre sufre una degradación por muy pequeña que sea, cuya única forma de evitar, en lo concerniente a la luz, es exponerlo guardándolo en una caja totalmente opaca. Pero entonces no estaríamos hablando de museos ${ }^{, 60}$.

Cualquier tipo de luz, ya sea natural o artificial, emite radiaciones visibles y no visibles al ojo humano, éstas son:

- La luz visible, es la comprendida entre los 400 y 700 nanómetros. Provoca daños en los bienes culturales porque se compone de unos fotones energéticos que golpean la superficie del objeto desgastándolo con el tiempo.

- Radiaciones ultravioletas, son radiaciones invisibles comprendidas por debajo de los 400 nanómetros. Producen efectos fotoquímicos que son más intensos cuanto menor sea la longitud de onda. Son las más dañinas para los bienes culturales, sobre todo las compuestas por material orgánico. En las sustancias poco estables, como los aglutinantes o pigmentos producen daños muy graves.

- Radiaciones infrarrojas, son radiaciones invisibles cuya longitud de onda está por encima de los 750 nanómetros. Provocan reacciones químicas en los objetos sólo cuando hay una elevación sensible de la temperatura.

Todas estas radiaciones, ya sea de origen natural o artificial, potencian la aparición de deterioros en los bienes culturales, así amarilleo, desecación, decoloración y destrucción.

Tendremos por tanto que controlar las radiaciones no visibles, de forma que la radiación infrarroja no eleva la temperatura de los objetos, sobre todo en vitrinas y

${ }^{59}$ Real Academia Española [1996], p. 1278.

${ }^{60}$ Coloma Martín, I. [1990], p. 9. 
lugares reducidos, ni afecte a la temperatura o a la humedad relativa del aire, y la radiación ultravioleta no debe superar los $75 \mathrm{mw} / \mathrm{lúmen}$. Por ello, como ya comentamos en el proyecto de iluminación, sustituiremos los cristales de las ventanas de las distintas dependencias del Monasterio por cristales difusores con filtro, para evitar estas radiaciones no visibles.

En cuanto a los materiales, unos pueden ser más sensibles que otros a la luz, esto depende de la capacidad intrínseca del material para absorber energía radiante y ser afectado por ella, los materiales que pueden clasificarse como sensibles son los siguientes:

- Pigmentos y tintes.

- Fibras textiles.

- Papel, madera y otros materiales celulósicos.

- Películas finas de materias orgánicas, tales como proteínas, resinas y gomas utilizadas en las pinturas, barnices y adhesivos.

Tendremos que tener en cuenta a la hora de exponer la colección del Monasterio de San Jerónimo de Granada los siguientes aspectos (para ello seguiremos las indicaciones de Raniero Baglioni ${ }^{61}$ ):

\section{- Límites de exposición a los rayos luminosos.}

Los límites anuales recomendados de exposición a los rayos luminoso son los siguientes:

\begin{tabular}{|c|c|c|}
\hline $\begin{array}{c}\text { Categoría de objetos } \\
\text { artísticos exposición }\end{array}$ & $\begin{array}{c}\text { Máxima } \\
\text { aconsejada Lux } \\
\mathbf{x} \text { hora } \mathbf{x} \text { año }\end{array}$ & $\begin{array}{c}\text { Iluminación máxima } \\
\text { aconsejada en lux }\end{array}$ \\
\hline Objetos poco sensibles & No limitada & 300 \\
\hline $\begin{array}{c}\text { Objetos } \\
\text { moderadamente } \\
\text { sensibles }\end{array}$ & 180000 & $75-100$ \\
\hline Objetos muy sensibles & 120000 & $40-50$ \\
\hline
\end{tabular}

${ }^{61}$ Baglioni, R. [1998], pp. 51-62. 


\section{- Niveles específicos de iluminación.}

Se recomienda limitar sólo al tiempo útil la iluminación de los objetos, o iluminarlos por turnos, hacerlo de tal manera que ningún rayo de luz incida directamente sobre los objetos frágiles, y si son muy frágiles estudiar la conveniencia de reemplazar los originales por copias.

\begin{tabular}{|c|c|c|}
\hline $\begin{array}{c}\text { Categoría de los } \\
\text { objetos expuestos }\end{array}$ & $\begin{array}{c}\text { Fuentes de luz } \\
\text { recomendada o admitidas }\end{array}$ & $\begin{array}{c}\text { Iluminación } \\
\text { aceptable }\end{array}$ \\
\hline $\begin{array}{l}\text { Objetos muy poco } \\
\text { sensibles a la luz } \\
\text { (metales, cerámicas, } \\
\text { minerales, joyas, } \\
\text { vidrios, esmaltes, } \\
\text { esculturas no } \\
\text { policromas en piedra) }\end{array}$ & $\begin{array}{l}\text { - Tubos fluorescentes de } \\
\text { temperatura de color entre } \\
4000 \text { y } 6000^{\circ} \mathrm{K} \text {. } \\
\text {-Lámparas incandescentes. } \\
\text { - Pequeños proyectores o } \\
\text { spot. } \\
\text { - Luz diurna controlada. }\end{array}$ & $\begin{array}{l}\text { No es necesario } \\
\text { sobrepasar los } \\
300 \text { lux, salvo } \\
\text { para destacar un } \\
\text { punto particular. }\end{array}$ \\
\hline $\begin{array}{l}\text { La mayor parte de las } \\
\text { categorías de objetos y } \\
\text { especimenes (pintura } \\
\text { al óleo, temple, cueros } \\
\text { naturales, objetos } \\
\text { lacados, madera, } \\
\text { cuerno, marfiles) }\end{array}$ & $\begin{array}{l}\text { Tubos fluorescentes de } \\
\text { doble capa que no emitan } \\
\text { ninguna radiación UV, o } \\
\text { tubos fluorescentes } \\
\text { corrientes de una } \\
\text { temperatura de color del } \\
\text { orden de los } 4000^{\circ} \mathrm{K} \text {, pero } \\
\text { necesariamente combinados } \\
\text { con el empleo de filtros } \\
\text { UV. } \\
\quad \text { Si se admite la luz del } \\
\text { día, deberán reducirse } \\
\text { severamente los rayos } \\
\text { infrarrojos y suprimir } \\
\text { totalmente los ultravioletas }\end{array}$ & $\begin{array}{l}\text { Máximo de } 150 \text { a } \\
180 \text { lux en } \\
\text { servicio }\end{array}$ \\
\hline $\begin{array}{l}\text { Objetos } \\
\text { particularmente } \\
\text { sensibles a la luz } \\
\text { (acuarelas, textiles, } \\
\text { tapicerías, vestidos, } \\
\text { impresiones, sellos, } \\
\text { miniatura, lámina, } \\
\text { tapicerías murales, } \\
\text { cueros teñidos, } \\
\text { especimenes de } \\
\text { historia natural) }\end{array}$ & $\begin{array}{l}\text { Tubos fluorescentes de } \\
\text { doble capa, de una temperatura } \\
\text { de color del orden de } 2900^{\circ} \mathrm{K} \text {, } \\
\text { o tubos fluorescentes de capa } \\
\text { simple, y de la misma } \\
\text { temperatura de color, con la } \\
\text { condición de suprimir } \\
\text { totalmente su radiación } \\
\text { ultravioleta por medio de } \\
\text { filtros. } \\
\text { La luz diurna deberá ser } \\
\text { totalmente evitada. }\end{array}$ & $\begin{array}{l}\text { No más de } 50 \text { lux } \\
\text { y si es posible } \\
\text { meno, ron } \\
\text { reducción severa } \\
\text { del tiempo de } \\
\text { exposición }\end{array}$ \\
\hline
\end{tabular}




\section{- Las fuentes luminosas.}

Hay que tener en consideración que las radiaciones responsables de las degradaciones de los objetos dependen del tipo de fuente de luz seleccionado y que no es suficiente controlar, en el sistema de iluminación seleccionado, la ausencia de radiaciones más peligrosas, sino lo más importante, verificar que la fuente luminosa no sobrepase los límites de iluminación máximos aconsejados para un determinado objeto.

Los criterios, por tanto, que tendremos en cuenta a la hora de seleccionar las fuentes luminosas para iluminar nuestra colección serán:

- La temperatura de color $\left({ }^{\circ} \mathrm{K}\right)$ y la distribución espectral de la fuente luminosa, sobre todo de la longitud de onda de las radiaciones ultravioletas y de las radiaciones infrarrojas.

- La vida media (horas totales de funcionamiento) de las lámparas utilizadas.

- La eficiencia luminosa $(\mathrm{lm} / \mathrm{W})$ de las lámparas utilizadas a fin de evaluar el consumo de energéticos y de las cargas térmicas introducidas en el ambiente.

"En sintesis, los profesionales de la conservación estamos obligados a planificar y aplicar un programa de conservación y de restauración que proteja, con los medios técnicos y humanos adecuados, el bien cultural contra todo proceso de destrucción o de alteración. Lo que requiere un conocimiento profundo de los agentes de deterioro externos e internos y del comportamiento y reacción de la propia naturaleza de los objetos a las agresiones del entorno, para poder aplicar la metodología preventiva y curativa más efectiva y respetuosa posible, sin perder de vida la realidad poniendo en práctica el más simple, pero al mismo tiempo el más complejo de los sentidos, que es el sentido común ",22.

\footnotetext{
${ }^{62}$ Baglioni, R. [1998], p. 61.
} 


\section{El Plan de Seguridad}

Habría que hablar de la seguridad en tres vertientes, el edificio y su entorno, las colecciones y el personal propio y los visitantes, pues se encuentran expuestos de manera potencial a determinados riesgos que debemos prevenir, así antrópicos, naturales, físicos, químicos, agentes biológicos, etcétera.

Al ser los responsables de la custodia y conservación del Monasterio de San Jerónimo y de todos los bienes muebles que éste alberga, pondremos en marcha un sistema de seguridad que vele por ese patrimonio, sin olvidar la seguridad de las personas, tanto la del personal de la institución como la de los visitantes. Somos conscientes de que puede ser una inversión elevada, pero muchas veces estas medidas preventivas se han tomado sólo después de que haya surgido el problema, y es entonces cuando el coste económico aumenta realmente.

En general, seguiremos uno de los principios básicos de la seguridad, la utilización de materiales resistentes al fuego y al agua, que no emiten humos al arder, que resisten golpes, sacudidas y vibraciones, y que sean los más duraderos posible. Además todo el diseño facilitará la visualización de las vitrinas y de objetos, desde cualquier punto de la sala, evitando la creación de zonas escondidas o en penumbra. El incumplimiento de estos principios, puede causar que el uso y la aplicación del sistema de seguridad resulten inútiles.

Nuestro plan de seguridad implicará la acción coordinada y conjunta de vigilancia humana y medidas físicas y electrónicas, lo que deberá garantizar que estemos cumpliendo con la responsabilidad de conservar, disfrutar y trasmitir el patrimonio histórico y artístico que nos ha sido legado.

Nos centraremos en la protección contra incendios, robo y vandalismo, pero no debemos olvidar que existen otros riesgos que hay que considerar en el proyecto de seguridad, con el objeto de prevenirlos, así:

- Previsión de conflictos bélicos.

- Expolio y tráfico ilícito.

- Condiciones de préstamos en exposiciones temporales.

- Necesidad de un buen sistema de documentación, todas las piezas deben estar inventariadas y fotografiadas.

- Control de visitas en las áreas reservadas al público, indicando en un parte de visitas: motivo, duración, zona visitada, etcétera.

\section{- El personal de seguridad.}

La vigilancia humana es básica en cualquier museo, ya que a pesar de que instalaremos en el Monasterio los instrumentos mecánicos y electrónicos 
necesarios, éstos los complementan de manera eficaz pero nunca pueden reemplazarla.

El Monasterio formará a su propio personal de seguridad, al que denominaremos de forma genérica vigilantes, en lugar de contratar los servicios de una empresa especializada (en caso de que se celebre una exposición temporal u otro evento de características similares, sí recurriremos a una empresa de seguridad), ya que creemos que aunque ésta ofrezca ventajas es mucho más importante que quieres vayan a vigilar el Monasterio se deban a él y no a una firma intermedia, además la institución intentará incentivarlos en su tarea, para que no se convierta en rutinaria y aburrida, lo que influiría en su rendimiento.

Contaremos con la presencia de vigilantes en todas las dependencias del Monasterio, por lo menos en cada sala, ya que pueden responder rápida y eficazmente ante posibles problemas, así, desde recordar a un visitante cuáles son las normas de conducta en el Monasterio, hasta detectar un conato de incendio y dar la alarma.

El Monasterio establecerá unas normas básicas de seguridad que deberán cumplir los visitantes y el personal del mismo, estas normas facilitarán el trabajo de los vigilantes, quienes serán los encargados de vigilar su cumplimiento, así:

- Prohibir fumar, comer o beber, salvo en las áreas expresamente destinadas a este fin.

- Impedir la entrada a las salas de bolsos o maletas mayores que una simple cartera de mano.

- No permitir el paso de objetos que pueden ser usados para atentar contra el mobiliario o las colecciones, así, paraguas.

- Hacer cumplir los recorridos propuestos, de tal forma que la entrada y la salida se hagan a través de un mostrador de control.

- Los sistemas de protección contra incendios.

El incendio es uno de los mayores riesgos que amenaza el museo. Existe una legislación referente a estos sistemas, lógicamente de obligado cumplimiento y a ella nos atendemos en este proyecto, así:

- Real Decreto 2177/1996, de 4 de octubre, por la que se aprueba la "Norma Básica de la Edificación NBE-CPI/96 Condiciones de Protección contra Incendios de los edificios".

- Real Decreto 1842/1993, de 5 de noviembre, por el que se aprueba el "Reglamento de instalaciones de protección contra incendios". 
El sistema de protección contra incendios deberá seguir el siguiente esquema: Prevención-Detección-Transmisión de la alarma-Extinción-Evacuación.

\section{- Prevención, deberemos actuar:}

- Sobre el combustible, con eliminación de los residuos combustibles, disponiendo de recipientes adecuados para el almacenamiento de líquidos y gases, ventilación adecuada de los locales con atmósferas inflamables, señalización adecuada de los recipientes y conducciones de gases y líquidos inflamables.

- Sobre los focos de calos, controlando los focos térmicos y los focos eléctricos.

- Control de la resistencia al fuego, clasificando a los materiales en función de su comportamiento.

\section{- Detección y Extinción.}

Todos los instrumentos que utilicemos en los sistemas de seguridad deberán de:

- Todos los equipos deberán estar de acuerdo a la normativa española y europea correspondiente.

- Todos los cuadros, dispositivos, etcétera, serán fijados sobre la superficie sobre la que vayan a ser montados, de forma nivelada y escuadrada, con una tolerancia de más menos $0,5 \mathrm{~mm}$.

- La instalación y el método de fijación de todos los dispositivos se elegirán de forma adecuada a la estructura del edificio, a la obra de fábrica y a los acabados sobre los cuales esté fijado.

- Los detectores y alarmas no se fijarán sobre partes provisionales o móviles de la estructura del edificio a menos que sea absolutamente necesario para lograr un funcionamiento satisfactorio del sistema.

- Todos los equipos serán inmunes contra señales radiadas y no deberán a su vez radiar señales que rebasen los límites establecidos.

- Todos los sistemas deberán ser adecuados para funcionar de forma continuada en las condiciones de medioambiente siguientes:

\begin{tabular}{|l|l|}
\hline Temperatura & $-10^{\circ} \mathrm{C}$ a $+40^{\circ} \mathrm{C}$ \\
\hline Humedad Relativa & $45 \%$ a $75 \%$ \\
\hline Presión barométrica & $86 \mathrm{kPa}$ a $106 \mathrm{kPa}$ \\
\hline
\end{tabular}




\section{- Detectores puntuales de calor.}

UNE 23007.

Los detectores puntuales de calor deberán estar de acuerdo con la norma

Deberán incluir simultáneamente elementos que respondan a la velocidad de aumento de temperatura, así como de temperatura fija. Cada elemento deberá reaccionar ante unos umbrales de sensibilidad diferentes. El detector deberá incluir la compensación automática de variaciones de las condiciones ambientales.

Los elementos sensores irán protegidos contra daños mecánicos.

Los detectores puntuales de calor se elegirán acordes con la temperatura del ambiente máxima.

La temperatura de funcionamiento nominal se elegirá acorde con la temperatura del ambiente.

- Detectores de humo fotoeléctricos.

Los detectores de humo fotoeléctricos serán según la norma UNE 23007.

Los detectores de humo fotoeléctricos (de dispersión de luz) deberán responder principalmente ante humo blanco. En los sistemas analógicos/direccionables, el detector se deberá ajustar automáticamente para compensar los efectos de acumulación de polvo y suciedad. La densidad del humo se medirá mediante un sistema óptico simétrico que utilice coincidencia múltiple de impulsos luminosos.

\section{- Detectores lineales por haz infrarrojo.}

Los detectores lineales por haz infrarrojo deberán cumplir con la normativa española y europea.

Deberán responder ante gases calientes y humo.

Los detectores ópticos lineales por haz infrarrojo funcionarán según el principio de detección por oscurecimiento utilizando un haz infrarrojo modulado invisible a prueba de manipulaciones.

El transmisor y el receptor se colocarán de tal forma que el haz no se vea interrumpido por el movimiento normal de las personas, por movimientos de maquinaria o componentes del edificio, así ventanas. Una interrupción del haz superior a 20 segundos deberá provocar una alarma de avería.

Se deberá disponer de compensación automática de la reducción de intensidad luminosa y de la suciedad en el transmisor y en el receptor. La absorción 
del haz debido a suciedad deberá provocar una alarma de fallo antes de que quede perjudicada la posibilidad de detección.

Se supervisará la potencia de salida del transmisor, las conexiones del receptor y la retirada de las carcasas. Cualquier fallo o interferencia deberá provocar una alarma de avería.

Los detectores ópticos por haz infrarrojo deberán disponer de regulación compensadora de la dirección e intensidad del haz, utilizando para ello equipos facilitados por el fabricante. La sensibilidad se deberá poder regular en el campo a unos niveles que dependan de la longitud del haz y de las condiciones locales.

Los detectores por haz infrarrojo estarán montados de tal manera que los movimientos previsibles que se produzcan en el edificio tales como dilatación o movimiento debido al viento, no afecten a su funcionamiento.

\section{- Detectores de llama.}

Los detectores de llama infrarrojos deberán detectar únicamente la radiación infrarroja oscilante. El ángulo de vigilancia deberá abarcar $100^{\circ}$.

El emplazamiento de los detectores de llama infrarrojos deberá asegurar una línea de visión clara sobre la superficie protegida. En la línea de visión o cerca de la misma no deberá haber ninguna fuente de radiación que no sea fuego, con el fin de no causar falsas alarmas. Se dispondrán unas máscaras adaptables en el campo para eliminar fenómenos engañosos, en los casos en que sea necesario.

La constante de tiempo característica de la sensibilidad y respuesta de los detectores de llama infrarrojos se elegirá acorde a la aplicación.

Para aplicaciones al aire libre se utilizarán detectores infrarrojos de doble sensor. Estos deberán ser sensibles dentro del campo de visión y ciegos a la radiación solar.

\section{- Extintores móviles.}

El extintor móvil se considera el elemento básico para un primer ataque a los conatos de incendio que pueden producirse en el edificio. Por ello se distribuirán extintores móviles en número suficiente para que el recorrido real en cada planta, y desde cualquier origen de evacuación hasta un extintor no supere los 15 metros.

Los extintores se colocarán en lugares muy accesibles, en las vías de evacuación horizontal, y junto a los equipos de manguera donde se indique así, con el fin de unificar la situación de los elementos de protección. 
Los extintores serán homologados, con su eficacia grabada en el exterior y equipados con manguera, boquilla direccional y dispositivo de interrupción de salida del agente extintor a voluntad del que lo este utilizando.

La clase de eficacia de los extintores, será dependiendo dentro de los lugares donde se vallan a ubicar y el tipo de fuego que se quiera extinguir. Los extintores que se van a utilizar serán:

- Extintores de polvo polivalente $\mathrm{ABC}$, para zonas generales. Las características de estos serán:

- recipiente de chapa de alta calidad, clase AP-04 según UNE 36.086 .

- válvula de disparo con cuerpo de latón y dispositivo de comprobación de presión incorporado.

- manómetro comprobable de máxima fiabilidad.

- manguera de vaciado protegida mediante tubo metálico y puño aislante del foco del fuego con difusor de gran radio y alcance de extinción o difusor de vaciado de gran radio y alcance de extinción según peso.

- Extintores de agua pulverizada, para las salas con máquinas y equipos. Las características que deberán presentar serán las siguientes:

- recipiente de chapa de alta calidad, clase AP-04 según UNE 36086, con recubrimiento interior anticorrosión,

- válvula de disparo con cuerpo de latón y dispositivo de comprobación de precisión incorporado.

- manómetro comprobable de máxima fiabilidad.

- manguera de vaciado de goma para alta presión y puño aislante del foco con difusor de gran radio y alcance de extinción.

- Extintores de anhídrido carbónico (CO2), para aquellas zonas que contengan aparatos eléctricos. Las características que deberán presentar serán:

- recipiente de chapa de alta calidad, clase AP-04 según UNE 36.086 .

- válvula de disparo de cuerpo de latón. 
- boquilla de difusor de gran radio y alcance de extinción.

\section{- Los pulsadores de alarma.}

Deberán comprender una placa base, un postizo y una tapa y serán adecuados para montaje al ras sobre cajas de aparatos estándar o para montaje superficial sobre cajas de montaje superficial hechas ex profeso. Las cajas de montaje superficial deberán combinar el color y el aspecto del pulsador de alarma.

Las tapas serán del tipo de encaje a presión, de color rojo y estarán fijadas de forma que se impida que se puedan quitar sin autorización. Deberá ser posible comprobar el pulsador de alarma sin tener que romper el cristal o quitar la tapa.

Todos los rótulos de inscripción se harán de forma permanente en la tapa, y no en el cristal. sellado.

En los pulsadores de alarma se utilizarán microinterruptores de tipo

La situación de alarma se mantendrá hasta que sea reinicializada por una persona autorizada, mediante una herramienta o una llave especial.

Los pulsadores de alarma que estén instalados en zonas donde pudiera haber problemas debido a fragmentos de cristal roto, deberán utilizar elementos frangibles cuando las piezas rotas queden contenidas dentro de la tapa del pulsador de alarma.

\section{- Bocas de incendio.}

Situaremos en el Monasterio, unas bocas de incendio equipadas de $25 \mathrm{~mm}$., estás deberán contar con las siguientes características:

- Estarán situadas en un armario metálico para montaje empotrado o adosado, según el caso, cuya puerta tendrá un marco metálico y vidrio señalizado.

- La puerta deberá disponer de un sistema de muletilla para apertura manual.

- El marco de la puerta será de acero inoxidable.

- La devanadera de alimentación axial sobredimensionada, giratoria, no pivotante y de baja perdida de carga interior 20m.1. de manguera semirígida Alfex 25.

- Válvula de bola de latón cromado. 
- Lanza de 25 normalizada, en polimero ABS antichoque.

- Manómetro incorporado de 0-16 bar, con esfera de $50 \mathrm{~mm}$

\section{- Grupo de presión contraincendios.}

El grupo de presión contraincendios del Monasterio, deberá tener los siguientes elementos:

- Bomba jockey de caudal, presión, potencia, motor y revoluciones indicadas en mediciones para pequeños consumos.

- Bomba de servicio con motor eléctrico de caudal, presión, potencia y revoluciones adecuadas.

- Bomba de servicio con motor diesel de caudal, presión, potencia y revoluciones determinadas.

Las características de las bombas y la potencia de los motores podrán suministrar un caudal $140 \%$ del punto de consigna con una presión del $70 \%$ de la de su punto de funcionamiento.

- Depósito cerrado de membrana de la capacidad y presión de timbre determinadas, con juegos de presosatos regulables. accesorios:

El montaje de las bombas y depósitos dispondrá de los siguientes

- Válvula de entrada a cada depósito de membrana.

- Válvulas de pie en el punto de aspiración de agua del colector de las bombas.

- Nivel de mínima o presostato para parada del grupo en caso de falta de agua y de máxima parando la válvula automática de llenado.

- Válvula en la aspiración de cada bomba.

- Filtros en la aspiración de cada bomba.

- Manguito antivibratorio en impulsión y aspiración de cada bomba.

- Conos reductores en impulsión y aspiración de cada bomba

- Manómetro de $10 \mathrm{~cm}$ de diámetro con llave y lira en la impulsión de la bomba.

- Válvula de retención en la impulsión de cada bomba. 
- Colector de prueba en impulsión de bombas.

- Colector en la impulsión de todos los circuitos.

- Juego de presostatos regulables.

- Válvulas de seguridad.

- Válvula para colector de pruebas.

- Caudalimetro.

- Sistema de cebado mediante dispositivo elevado de agua controlada por electroválvula y nivel conexionado a cada impulsión de bomba con válvulas dobles de retención.

\section{- Protección contra el robo.}

La mayor parte de los problemas de seguridad de los museos son consecuencia de la estructura de los edificios y de los materiales empleados en la construcción, por lo que antes de elegir un sistema determinado de protección, deberemos:

- Realizar un estudio general del edificio.

- Controlar las colecciones mediante la elaboración completa de inventarios de los fondos.

- Conocer el movimiento de los fondos de una manera exacta.

- Controlar el personal interno del monasterio.

- Controlar a los visitantes del monasterio.

El sistema de protección que se instalará en el Monasterio de San Jerónimo se hará en tres niveles:

- Protección periférica y perimétrica.

- Protección volumétrica.

- Protección del objeto. 


\section{- Protección periférica y perimétrica.}

Este sistema de protección está concebido para impedir que personas no autorizadas tengan acceso a las distintas dependencias del Monasterio fuera del horario de apertura. Las medidas de protección que emplearemos serán por un lado pasivas y por otro activas.

Las medidas pasivas tienen como objetivo delimitar el perímetro del Monasterio, éstas consistirán en los muros del edificio, rejas en las ventanas o cerraduras en las puertas de acceso.

Las medidas activas, complementan a las anteriores, se ponen en marcha una vez que se ha llevado a cabo la intrusión. Tienen como finalidad detectar, comunicar y registrar el acceso de las personas. Estos sistemas, llamados de detección, están constituidos por elementos eléctricos y electrónicos que actúan al recibir la señal que produce su activación. Entre los sistemas que existen vamos a utilizar:

- Detector de rayos infrarrojos, está compuesto por un transmisor y un receptor, estableciéndose entre ellos una línea no visible que detecta cualquier interrupción que se produzca. Nos son de gran utilidad ya que pueden proteger espacios amplios, además destacan por su reducido coste y su bajo índice de falsas alarmas, aunque tienen el inconveniente de que pueden salvarse con cierta facilidad.

Colocaremos uno en todas las dependencias del Monasterio. También los pondremos en el claustro, pero cubiertos con carcasas especiales para protegerlos de las condiciones medioambientales externas.

- Contactos magnéticos en las puertas y ventanas, se instalan con gran facilitad y son muy económicos, aunque se puede penetrar a través de ellas sin necesidad de abrirlas.

- Detector de rotura de cristal, su objetivo principal es la protección de zonas acristaladas, como vanos.

- Videosensores, son detectores que utilizando una señal de vídeo procedente de una cámara de televisión, se activan al producirse una variación predeterminada del nivel de luminosidad en la zona protegida.

\section{- Protección volumétrica.}

Esta protección está pensada para impedir la entrada a las distintas dependencias del Monasterio a personas no autorizadas, los dispositivos que utilizaremos son muy semejantes a los de la protección perimétrica.

- Protección del objeto. 
Este tipo de protección va enfocada a una protección puntual de los objetos. Los objetos tendrán una sujeción fija, las esculturas de pequeño tamaño estarán expuestas en el interior de vitrinas y en cuanto a la protección de los cuadros o grandes esculturas instalaremos un sistema anti-alarma, lo colocaremos tras la pieza disparándose la alarma si se toca.

\section{- Seguridad interna.}

La seguridad interna del Monasterio residirá en última instancia en un personal de confianza, desde el director hasta el servicio de limpieza.

Todo el personal permanente, el contratado de forma temporal o colaborador deberá ser provisto de una credencial, con el fin de facilitar la labor de los vigilantes.

No se permitirá la entrada de visitantes a las áreas privadas, salvo que estén autorizados, en cuyo caso siempre irán acompañados.

Después de las horas de trabajo normal, los miembros del personal y quienes les acompañen deberán consignar su entrada y salida en un registro que llevará el vigilante que se encuentre de guardia a la entrada del Monasterio o del área no abierta al público.

Todas las áreas restringidas deberán mantenerse cerradas con llave, llaves cuya asignación será limitada.

Ningún objeto, cualquiera que sea su naturaleza, debe salir sin los documentos o permisos que demuestren la autorización o posesión personal.

Por último señalar, que se hará comprender al personal de la importancia de no discutir detalles de la seguridad del edificio y de las colecciones con personas ajenas a la institución. Del mismo modo, no debe hacerse público ningún informe general sobre los puntos débiles de la protección del Monasterio, la impresión que debe darse al exterior es que el Monasterio de San Jerónimo está muy bien protegido.

\section{- Seguridad de las personas.}

Nuestra institución será responsable no sólo de la seguridad de su patrimonio sino también de las personas que la visitarán y de quienes en ella trabajan. Deberemos estar preparados ante cualquier situación de emergencia que se pueda presentar, por lo que tomaremos algunas medidas.

\section{- $\quad$ Límite de densidad.}

Los edificios que van a tener un uso público deben ser diseñados con espacios que eviten las aglomeraciones, ya que un número excesivo de personas en 
un espacio presenta numerosos riesgos, así, pánico en caso de humo o fuego, mareos por falta de ventilación o incluso el peligro de que el piso se hunda, al no haber sido calculados para soportar la sobrecarga que suponen las multitudes.

Para evitarlo, limitaremos el número de visitantes en el interior del Monasterio de San Jerónimo, controlándose el ritmo de entradas y salidas, en general y a ciertas salas en particular y estableciendo un nivel máximo de densidad, pro ejemplo 3 personas por cada $2 \mathrm{~m}^{2}$ de suelo accesible.

También, limitaremos las visitas de grupos de escolares durante las vacaciones y otros períodos de gran afluencia, que suelen coincidir en primavera (al menos en algunas ciudades).

\section{- Prevención de accidentes.}

Estudiaremos el edificio en su conjunto para eliminar los posibles peligros que pueden provocar un accidente tanto a los visitantes como al personal del Monasterio.

La iluminación del interior y del exterior será abundante y estableceremos un sistema de iluminación de emergencia para facilitar la evacuación en caso de emergencia (Este punto ya lo desarrollamos al hablar de la iluminación, por lo que aquí no se incidirá en él).

El taller de restauración, como ya señalamos, contará con unas medidas especiales ya que en él se encuentran productos altamente peligrosos.

Para atender posibles accidentes que puedan darse entre el personal o los visitantes contaremos con un botiquín, cuyo contenido se controlará regularmente.

\section{- Sistema de megafonía de alarma.}

Se instalará un sistema de alarma, este será de voz y automático, y dará una cobertura total a todas las áreas del edificio.

Los objetivos principales del sistema serán los siguientes:

- La transmisión de una señal acústica perceptible en todo el edificio, lo que permitirá el conocimiento de la existencia de un incendio por parte de todos sus ocupantes.

- La comunicación con el personal en caso de urgencia y para proporcionar otras informaciones de seguridad. 
- Conseguir las condiciones auditivas apropiadas al Monasterio.

- Regular los sonidos y vibraciones dentro de los límites apropiados para la variedad de actividades que tendrán lugar en el edificio.

El sistema de alarma estará zonificado, con la idea de poder dar diferentes avisos y alarmas diferentes, o iguales, según los casos, a cada una de estas zonas dependiendo de la mejor operación de los sistemas de seguridad, evacuación y emergencia del edificio. El sistema de megafonía de alarma deberá cumplir con los siguientes requisitos:

- Se dispondrá de un mensaje de alarma adecuado, que estará grabado, el cual se podrá transmitir de forma automática en respuesta a una señal de incendio. Esta transmisión se hará sin la presencia de un operador.

- Difusión, tanto automática como manual, de mensajes pregrabados de forma selectiva o general a tantas zonas como sean necesarias.

- Todos lo mensajes de megafonía serán claros, cortos, inequívocos y, si es posible, planeados con anterioridad.

- El número y tipo de altavoces instalados del sistema de megafonía de alarma, deberá ser suficiente para producir un nivel sonoro de la alarma mínimo de 65 decibelios, o bien, de 5 decibelios por encima de cualquier otro posible ruido que pueda durar más de 30 segundos, debiendo adoptarse el valor más elevado de ambos.

- El sonido que se reciba en todas las salas deberá ser lo más comprensible posible.

- El intervalo entre los sucesivos mensajes no excederá de 30 segundos, se usarán señales de fondo $\mathrm{o}$ relleno similares a las utilizadas convencionalmente cuando los períodos de silencio excedan de los 10 segundos.

- Mientras dure el estado de alarma todas las fuentes de sonido conectadas a este sistema se desconectarán, exceptuando el micrófono (o micrófonos) par mensajes de alarma y los módulos de mensajes hablados que dan la alarma.

El sistema deberá ser capaz de producir unos niveles generales de sonido que especificamos en la tabla siguiente: 


\begin{tabular}{|l|l|}
\hline Zona & $\mathrm{dB}$ \\
\hline Salas del monasterio & $75 \pm 2$ \\
\hline Iglesia & $80 \pm 3$ \\
\hline Oficinas & $75 \pm 2$ \\
\hline Zonas de circulación & $80 \pm 3$ \\
\hline Zonas con maquinaria & $90 \pm 2$ \\
\hline Entrada & $80 \pm 3$ \\
\hline
\end{tabular}

Pero además, el sistema podrá ser capaz de producir un nivel de sonido continuo por lo menos de $3 \mathrm{~dB}$ más alto que el especificado anteriormente. También, el nivel sonoro medio efectivo de la señal para llamar la atención (alarma) antes de un mensaje verbal de peligro, estará entre $-0 \mathrm{~dB}$ y $+3 \mathrm{~dB}$ del nivel sonoro medio del habla.

Los mensajes serán grabados con voz real, no sintetizada, los hará una persona con voz clara (si fuera posible, un profesional), los de alerta, serán con voz de mujer, sin acento y los de emergencia, con voz de hombre, sin acento. Primero se dirán en español y después en inglés.

\section{Los mensajes serían así:}

El mensaje de alerta consistirá en una señal de cinco segundos aprobada para atraer la atención, seguido de las palabras: "POR FAVOR ATENCIÓN, POR FAVOR ATENCIÓN. ESTAMOS INVESTIGANDO UNA SITUACIÓN DE ALARMA., PUEDE SER NECESARIA LA EVACUACIÓN DEL EDIFICIO. POR FAVOR ESTEN ATENTOS A FUTUROS ACONTECIMIENTOS” y después "PLEASE, PLEASE. WE ARE.......". El mensaje completo (señal y texto) se repetirá continuamente con intervalos de 30 segundos.

El mensaje de evacuación consistirá en una señal de cinco segundos aprobada para atraer la atención, según lo especificado en la normativa, seguido de las palabras: "POR FAVOR ATENCIÓN, POR FAVOR ATENCIÓN. ESTO ES UNA EMERGENCIA. POR FAVOR ABANDONEN EL EDIFICIO POR LA SALIDA DE EMERGENCIA MÁS PRÓXIMA", a continuación "PLEASE...". El mensaje completo se repetirá continuamente sin intervalo.

Los altavoces que elegiremos serán, altavoces planos, montados en la superficie de la pared, cuyas rejillas y colores estarán subordinados a la arquitectura del espacio en la que se ubiquen.

Todos deberán ser resistentes al fuego por su construcción o por sus cerramientos. La instalación del circuito de alimentación al altavoz debe tener una protección máxima contra el fuego. Los altavoces externos deberán ser resistentes a la intemperie, con un grado de protección acorde a la normativa vigente 
Concluiremos resaltando que para que todo lo descrito pueda ser llevado a cabo de forma adecuada, es imprescindible que:

- Tener un buen sistema de documentación (Inventario y fotografías de todas las piezas).

- Conocer la situación exacta de cada pieza, controlar los movimientos internos y externos.

- Vigilar al visitante, ya que puede ser un potencial agresivo, consciente o inconscientemente.

- Revisar el edificio y las obras expuestas diariamente por parte del personal de vigilancia.

- Disponer de un equipo de profesionales, organizados, formados y adiestrados en este tipo de tareas.

Señalar, por último la necesidad de redactar un Plan Integral de Seguridad, en el que se integrarán los planes de emergencia y evacuación. En ellos se debe implicar todo el personal de la institución. Se regirá por la Orden de 29 de noviembre de 1984, por la que se aprueba el Manual de Autoprotección para el desarrollo del Plan de Emergencias contra Incendios y Evacuación de locales y edificios y la Normativa Básica de Edificaciones CPI 96. 
VI. EL SISTEMA DE DOCUMENTACIÓN. 


\section{EL SISTEMA DE DOCUMENTACIÓN.}

El sistema de documentación es uno de los instrumentos básicos para conseguir el buen funcionamiento del museo, ya que la documentación es la base para la gestión de las colecciones, la investigación de los objetos y la seguridad y control de los movimientos de los fondos. El sistema de documentación debe reunir y registrar la máxima información posible acerca de todos los fondos del museo ya que las informaciones sobre las piezas, que nos explican su vida y sus problemas pasados, son tan importantes e incluso más que los objetos mismos. Las informaciones inherentes al objeto pueden ser recogidas siempre; en cambio, su historia, si se pierde, se pierde para siempre ${ }^{63}$.

De la calidad del sistema de documentación va a depender el grado de conocimiento que tengamos de nuestras piezas, es decir, de nuestro museo, además existe una importante responsabilidad profesional de asegurar que todos los objetos aceptados temporalmente en un museo sean provistos de una documentación completa y detallada que facilite su identificación, procedencia, estado y tratamiento. ${ }^{64}$

El sistema de documentación que vamos a seguir en nuestro museo deberá de presentar las siguientes características:

- Cubrir todo el campo, la documentación museológica debe cubrir todo su campo, tanto de los fondos como de los documentos.

- Actualizado, los instrumentos documentales deberán de ponerse al día sistemáticamente. En el momento que un dato deje de actualizarse, el instrumento pierde valor y paralelamente la pieza a la que pertenece ese dato "se pierde", así por ejemplo, desconoceremos su ubicación.

- Sencillo, tanto su organización como funcionamiento deberán facilitar su uso y no complicarlo.

- Flexible, no intentar reducir excesivamente el número de instrumentos ni atribuir a alguno funciones o datos que no puede acoger.

- De uso público, la documentación tiene como objetivo la recuperación de toda la información conservada en el museo para su uso público. Si los instrumentos museológicos no son accesibles al público, no son efectivos.

- Estable, hay que intentar mantener siempre los mismos criterios.

\footnotetext{
${ }^{63}$ Porta, E., Montserrat, E. [1982], p. 18.

${ }^{64}$ ICOM. [1986], p.31.
} 
Para conseguirlo vamos utilizar tres instrumentos, el Libros de registro, el Inventario y el Catálogo. El soporte de estos será tanto el papel tradicional como el informático.

\section{- Libro de registro.}

E1 Registro "es el control de entrada y salida de los objetos del museo" "65.

Tendremos un libro de registro general de las colecciones del monasterio, cuyo objetivo será la inscripción de los datos relativos a la identificación básica de los bienes que los integran, constituyendo por tanto, el principal instrumento jurídico y administrativo que acredite y proteja los fondos del monasterio, es decir, será un documento con valor legal en caso de robo o reclamación. En él se anotarán las altas y las bajas de todas las piezas del monasterio en el momento en el que se producen, nos dará toda la información primaria de todo el sistema de documentación y nos asegurará que sólo se ha dado un número a cada uno de los objetos y que no existen lugares vacíos en la numeración.

Para la creación de este libro de registro seguiremos las indicaciones que el Ministerio de Cultura dio en al año 1988 en relación con los registros de los museos estatales, así:

- Abriremos el libro haciendo constar en la Diligencia de apertura la fecha de inicio y el número de hojas, para lo cual se enumerará el Libro en el recuadro destinado al efecto en la parte superior derecha de cada hoja.

- El número de registro se asignará correlativamente por orden cronológico de entrada y bajo ningún concepto podrá duplicarse.

- La fecha de ingreso se consignará en números árabes.

- Los objetos se designarán atendiendo a su propia naturaleza, como por ejemplo, pintura o escultura.

- La descripción deberá contener referencias precisas a técnicas y materiales, a autores o en su defecto escuelas, cronologías y títulos.

- Las dimensiones se consignarán en centímetros por este orden: altura, anchura y profundidad. (En el caso de dibujos y grabados, las dimensiones se consignarán en milímetros).

- El estado de conservación, se referirá al momento preciso en que el objeto ingrese en el museo.

\footnotetext{
${ }^{65}$ Porta, E., Montserrat, E. [1982], p.19
} 
- En la forma de ingreso se especificará si la entrada de la pieza en el museo ha sido por hallazgo, compra, donación, legado testamentario, impuestos sobre sucesiones, renta o patrimonio.

- En procedencia se hará constar en cada caso lo que más convenga a la mejor identificación de la pieza: procedencia geográfica o poseedor anterior.

- En observaciones se anotarán aquellos datos que se consideren necesarios para completar la identificación de depósitos en otras instituciones, etcétera.

Una hoja de este Libro sería así:

LIBRO DE REGISTRO DE LA COLECCIÓN DEL REAL MONASTERIO DE SAN JERÓNIMO DE GRANADA.

\begin{tabular}{|l|l|l|l|l|l|l|l|l|l|}
\hline $\begin{array}{l}\mathrm{N}^{\mathrm{o}} \text { de } \\
\text { Registro }\end{array}$ & $\begin{array}{l}\text { Fecha } \\
\text { de } \\
\text { ingreso }\end{array}$ & Objeto & $\begin{array}{l}\text { Descri } \\
\text { pción }\end{array}$ & $\begin{array}{l}\text { Dimen } \\
\text { siones }\end{array}$ & $\begin{array}{l}\text { Estado } \\
\text { de } \\
\text { conser } \\
\text { vación }\end{array}$ & $\begin{array}{l}\text { Proced } \\
\text { encia }\end{array}$ & $\begin{array}{l}\text { Forma } \\
\text { de } \\
\text { ingreso }\end{array}$ & $\begin{array}{l}\mathrm{N}^{\circ} \text { de } \\
\text { Expedi } \\
\text { ente }\end{array}$ & $\begin{array}{l}\text { Observ } \\
\text { aciones }\end{array}$ \\
\hline & & & & & & & & & \\
\hline & & & & & & & & & \\
\hline & & & & & & & & & \\
\hline
\end{tabular}

Además de éste libro de registro, de las colecciones del Monasterio de San Jerónimo, contaremos con otro libro, un libro de registro de las piezas que hayan sido depositadas en el monasterio por cualquier otra institución o por un particular, siendo las piezas inscritas en él del mismo modo que en el de las colecciones del monasterio, con la diferencia de que en el apartado de observaciones se hará constar el número de inventario asignado en la colección de la que procede, y, en su caso, se indicará la fecha del levantamiento del depósito.

\section{- El Inventario.}

Podemos definir Inventario como "un listado más o menos completo de la totalidad o de una parte de los objetos de un museo". ${ }^{66}$

La finalidad del inventario será la de identificar un objeto cualquiera del monasterio, o conocer los fondos con independencia de su significación artística o científica dentro de las colecciones. Hay que tener en cuenta que el inventario no es el registro, aunque éste puede ser elemento indispensable para su confección. La numeración del inventario será correlativa, de modo que la última cifra de éste, una vez deducidas las bajas, si las hubiera, nos dará el número exacto de objetos inventariados existentes en nuestro monasterio. Por razones de seguridad, se

${ }^{66}$ Porta, E., Montserrat, R. M., Morral, E. [1982], p.19 
conservará un duplicado de cada ficha de inventario en un lugar fuera del monasterio.

El modelo de ficha de inventario de cada pieza debe contener según el CIDOC nueve atributos básicos: nombre del museo o de la institución, número de registro, nombre del objeto, clasificación genérica, descripción, forma de ingreso, fuente de ingreso, fecha de ingreso e historia del objeto, aunque estos pueden ampliarse según las necesidades del museo.

Nosotros seguiremos el siguiente modelo para San Jerónimo:

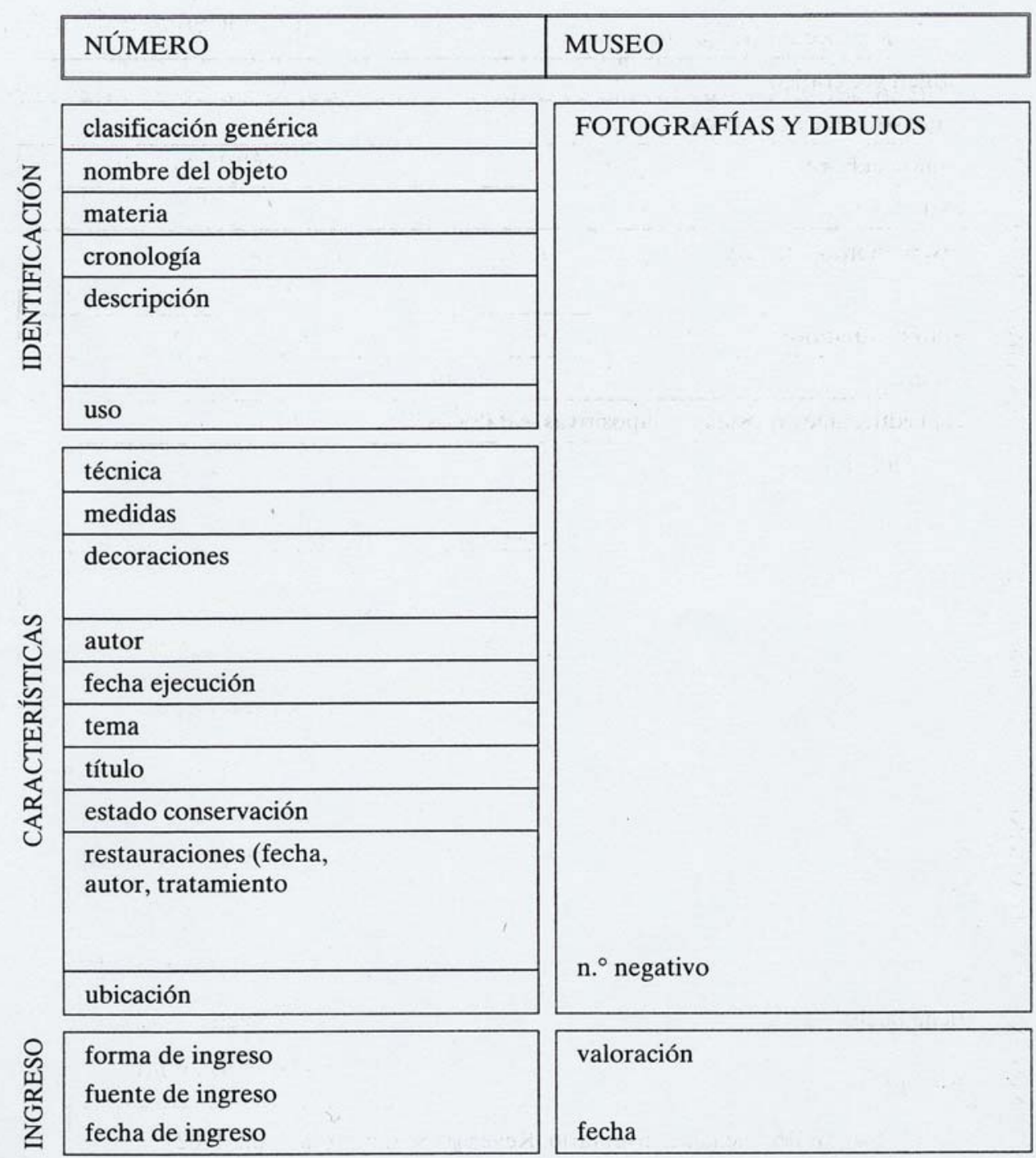

Ficha de Inventario. Anverso (Según Porta, Montserrat, Morral, 1982) 

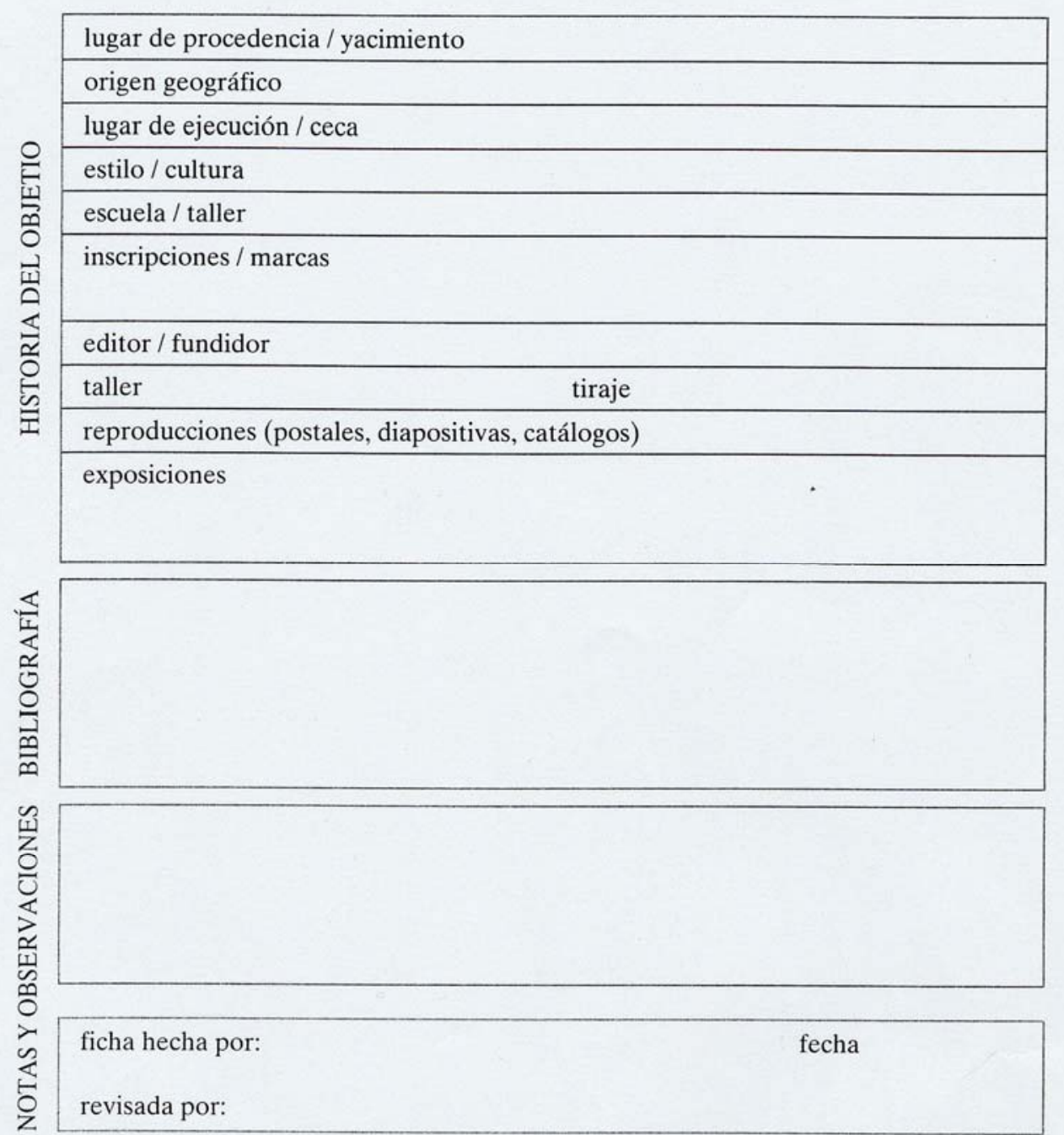

Ficha de Inventario. Reverso (Según Porta, Montserrat, Morral, 1982)

\section{- El Catálogo.}

El catálogo es el instrumento que tiene como finalidad documentar y estudiar los fondos asignados al Museo y los depositados en el mismo en relación con su marco artístico, histórico, arqueológico, científico y técnico. El catálogo deberá contener los datos sobre el estado de conservación, tratamientos, bibliografía y demás incidencias análogas relativas a la piez ${ }^{67}$.

${ }^{67}$ Reglamento de los Museos de titularidad Estatal y del Sistema Español de Museos, art. 12.1 
Las fichas del catálogo permiten un acceso más directo a la documentación. La mayoría de los museos tienen dos tipos de catálogos, el sistemático y el monográfico, son los dos tipos que en 1942 estableció Navascués. Nosotros sin embargo, debido a que el número de piezas no es muy extenso trabajaremos sólo con un catálogo, que abarcará toda la documentación generada por la colección. Por cada pieza se abrirá una carpeta de cartulina, en cuyo anverso se situarán los mismos datos que en el inventario, además de una fotografía, lo que facilitará la búsqueda de información de una pieza, en el interior, se consignarán todos los datos de identificación del objeto, describiéndose éste de forma muy detallada y se agruparán todos los antecedentes, trabajos o estudios a que haya dado lugar esa pieza, por lo que la carpeta siempre estará abierta a una nueva información. En cuanto a las observaciones sobre la limpieza, conservación y restauración, se incluirán en la carpeta como parte de la documentación del objeto.

\section{- El Archivo fotográfico.}

Tendremos un archivo fotográfico, no de fotografías consideradas como piezas en sí mismas del Monasterio, sino como documentos que ilustran las obras del Monasterio, es decir, un archivo de los negativos o de las copias de las fotografías de los objetos del inventario general; de las fotografías de detalles de una obra determinada o de su aspecto antes, durante y después de una restauración o de un traslado, de grabados o postales que muestran la obra en su lugar de origen, etcétera.

Toda pieza del Monasterio deberá estar fotografiada ya que constituyen un complemento imprescindible de todo sistema de documentación que nos ayudan a la identificación de las mismas.

Fotografiaremos los objetos colocando sobre éstos su número de inventario, de modo que con esta operación relacionaremos siempre el objeto, su fotografía y el negativo.

Tanto las fotografías como los negativos llevarán el mismo número, es decir, el de inventario de la pieza, ya que una numeración separada podría inducir a confusiones.

Los negativos de medida pequeña, a partir de $6 \times 6 \mathrm{~cm}$ por ejemplo se almacenarán en álbumes archivadores, éstos llevarán hojas divididas en tiras y que a tal fin adquiriremos en los establecimientos fotográficos.

Además estarán todas digitalizadas, pudiendo ser consultadas por el público más interesado en el ordenador.

\section{- La numeración de las piezas}

Para la numeración de las piezas adoptaremos el sistema de un solo número, enumerando las piezas de forma correlativa, por ejemplo: 
1. Virgen de las Angustias.

2. San José.

3. San Pedro penitente, etc.

En el caso de que una pieza este constituida por varias piezas a su vez, la numeración se hará de la siguiente forma:

\section{Retablo de San Jerónimo. \\ 35.1. San Cosme y San Damián. \\ 35.2. Santa María Egipciaca.}

De este modo, sabremos el volumen de fondos del museo. Tras numerar la pieza, hay que marcarla. En cuanto al etiquetaje y marcaje de los números del inventario en las piezas, no existe realmente un consenso respecto a los métodos de aplicación, nosotros vamos a seguir las reglas que se dan en la ficha técnica número 2 del CIDOC, estas normas estarán a disposición del personal del museo, así:

\section{Reglas generales:}

- Los números del inventario constituyen el nexo de unión entre los objetos y la documentación con ellos relacionada. Estos, por tanto, deben estar físicamente unidos al objeto o inscritos directamente en él.

- Cuando un objeto llegue a formar parte de la colección del museo recibirá un número. La aplicación de este número deberá hacerse siguiendo un método seguro, es decir, que el objeto no resulte dañado en el proceso, pero asegurándose, además, de que dicho número no se pierda accidentalmente.

- Si al objeto se le diera un número provisional (así en caso de préstamo), se utilizarán etiquetas.

- El etiquetaje y marcaje de los objetos se hará de forma consecuente por el personal cualificado. Se debería de dejar siempre un lapso de tiempo suficiente que permita examinar el objeto, limpiar su superficie con el método apropiado y aplicar el número asignado.

- En caso de duda, se debe consultar al restaurador. Hay que tener en cuenta que ningún método es absoluto ya que la mayoría de los productos y métodos usados más frecuentemente no han sido todavía sistemáticamente probados.

- Las operaciones de etiquetaje y marcaje de números no deben nunca dañar al objeto y al mismo tiempo ser reversibles, es decir, los números tendrían que poder ser eliminados sin dejar rastro alguno, aunque esto no sería de ayuda en caso de pérdida o robo.

- El número debe ser encontrado con facilidad sin manipulaciones innecesarias y al mismo tiempo debe hallarse en un lugar que no altere el aspecto del objeto. 
- Aunque cada tipo de objeto requiere sus propias técnicas de marcaje, se recomienda reducir al máximo los métodos y materiales empleados.

- Cuando un objeto se componga de varios materiales, se deberá escoger para su marcaje el lugar más idóneo.

- Cuando el objeto se componga de varias piezas o partes que se conserven separadamente, cada una de ellas será numerada.

Evitaremos eliminar los números antiguos, pues pueden aportar información sobre la historia del objeto. Si estos por algún motivo deben ser eliminados se anotarán en la documentación.

\section{Posición:}

- En un mismo tipo de objetos, los números aparecerán en el mismo lugar para evitar manipulaciones inútiles. Hay que evitar tener que coger los objetos frágiles o pesados para encontrar el número. Si los objetos son muy grandes habrá que ponerles etiquetas suplementarias. Si el objeto está embalado o guardado en una caja, el número también estará en el envoltorio. del objeto.

- El número debe ser emplazado en un lugar que no afecte a la apariencia

- Si los objetos son muy pequeños, se numerarán en una etiqueta o con el sistema de "microtrace".

- Con el fin de evitar que los números desaparezcan accidentalmente, éstos no deben aplicarse sobre superficies inestables o partes sometidas a roces o desgastes.

- No se pondrá el número en el fondo de objetos muy frágiles o pesados.

\section{Métodos:}

- Los métodos y materiales utilizados para el marcaje de números en ningún caso deben implicar riesgos de daño permanente en el objeto.

- El método elegido debe ser reversible al tiempo que ha de garantizar la permanencia del número en sí mismo. Aunque las etiquetas de cartón atadas al objeto sean probablemente lo que menos dañe al objeto, sin embargo, el marcaje directo de los objetos, siempre que sea posible, es el método más seguro.

- El número debe ser fácilmente legible. Se usarán caracteres negros sobre fondos claros y caracteres blancos sobre fondos oscuros, también pueden usarse de color rojo para ambos tipos de fondos. 
- Con el fin de reforzar la relación existente entre el objeto y su documentación, se incluirá el número en algunas de las fotografías del objeto.

Los métodos utilizados estarán condicionados por las características físicas del objeto, así:

- En las superficies duras y no porosas, el número se escribirá con tinta no ácida y soluble en agua o con pintura acrílica. Se puede aplicar una capa de barniz acrílico en la superficie una vez limpia, así como sobre el número para protegerlo.

- En las superficies duras y porosas, se aplicará el mismo método, pero la superficie limpia debe ser protegida siempre con una capa de barniz acrílico antes de aplicar el número. blando.

- En las superficies de papel, el número debe ser marcado con un lapicero

- En los textiles, se pondrán etiquetas prefabricadas en tela, cosidas con pocas puntadas, y utilizando una aguja e hilo apropiado.

- Las superficies pintadas o lacadas, así como los plásticos deben ser tratados con especial cuidado ya que pueden ser sensibles a los materiales usados habitualmente para el marcaje de objetos.

\section{Evitaremos:} metal

- estampar números al calor o grabarlos directamente sobre la madera o el

- atornillar placas de metal en la madera

- usar tampones o tinta sobre el papel

- poner sobre cualquier material etiquetas adhesivas (incluidas las de código de barras) sin haber aplicado antes una capa protectora

- usar rótulos afilados o alambres

- usar como capa protectora productos originalmente concebidos para otros propósitos y materiales, especialmente cuando la composición del producto no se conoce con precisión.

\section{- El sistema informático. Odiseus.}

Como ya dijimos el sistema de documentación que hemos seleccionado para nuestro Monasterio Museo de San Jerónimo, estará contemplado tanto en el soporte tradicional, papel, como en el soporte informático. 
Hoy día, ya no es posible pensar en un tipo de gestión tradicional, pues la informática se ha convertido en un instrumento de uso común, ya que el sistema más eficaz para gestionar, almacenar y recuperar todo tipo de información. Nuestro objetivo no es únicamente satisfacer las necesidades internas de la institución sino que en un futuro cercano se ampliará su acceso y uso al público, además podremos estar integrados con otros museos mediante este sistema de información.

Los distintos programas que hay en el mercado responden a estas necesidades, de acuerdo a cada caso particular. Nosotros instalaremos el programa Odiseus, un programa informático par ala gestión de bases de datos de los museos andaluces. Con el diseño de este programa, se ha intentado cubrir las necesidades de documentación e información de los museos andaluces para la gestión y la investigación científica de sus colecciones, para ello se ha creado un sistema de información abierto y flexible que permite introducir la información básica sobre cada pieza, así como toda la información científica que se vaya generando.

En el diseño de estas bases de datos de museos se ha tenido en cuenta el futuro vertido de su información en la base de datos del Catálogo General de Bienes Muebles de la Consejería de Cultura de la Junta de Andalucía. Es por ello, por lo que se ha acordado la similar cumplimentación de diversos campos, así como la introducción automática de los dígitos correspondientes a la provincia, municipio, edificio y tipología, definidos por la Dirección General de Bienes Culturales para identificar a los bienes del patrimonio histórico andaluz.

Odiseus es un paquete integrado para la gestión de las bases de datos en los museos que se compone de cinco ficheros:

- Fichero de piezas.

- Fichero bibliográfico.

- Fichero de imagen.

- Fichero administrativo.

Estos ficheros contienen diferente tipo de información relacionada con los fondos del museo (el fichero de piezas - la catalogación de fondos, el fichero bibliográfico - las referencias bibliográficas sobre la pieza y relacionadas con la biblioteca del museo, el fichero de imagen - información referente a los distintos tipos de imágenes de las piezas y el fichero de sonido - grabaciones relacionadas con el tema y el fichero administrativo-todo tipo de documentación generada por los movimientos de las piezas).

Todos los ficheros son independientes y la introducción de datos también; y previa lincación, se relacionan estos entre sí mediante un vínculo común, el número de registro de la pieza. 
La base de datos que nos interesa comentar es la de las piezas, ya que es la que mejor se adapta a nuestras necesidades, que describimos a continuación.

Ésta está diseñada con una serie de campos limitados y otros libres, con objeto de facilitar la recuperación de información. Se compone de tres pantallas:

- Primera pantalla. En ella se han establecido una serie de campos limitados comunes para todos los museos andaluces independientemente de su especialidad, relativos a la gestión de la pieza. Se conoce esta primera pantalla como pantalla de gestión.

- Segunda pantalla. En esta se han añadido una serie de campos limitados, los que se han considerado necesarios para cada especialidad (Arqueología, Bellas Artes y Etnología) con el objetivo de tener una completa definición y un mejor conocimiento de sus fondos.

- Tercera pantalla. La característica fundamental de esta pantalla es que permite ampliar la información de todos los campos de las dos pantallas anteriores, ya que está concebida en texto libre e introduce algunos campos nuevos, no incluidos anteriormente, permitiendo al catalogador introducir toda la información científica existente sobre la pieza sin límite de espacio, aunque la recuperación de esta información es más lenta que la de las dos primeras pantallas.

Este programa tiene establecidos, dos niveles de acceso, las dos primeras pantallas son de acceso libre y directo para los investigadores y el público en general y la tercera pantalla en principio también es de acceso libre pero tienen una serie de mecanismos que permiten al personal del museo dedicado a la catalogación de los fondos determinar que información de la incluida en esta pantalla será de consulta pública o de consulta interna. El programa no contempla campos opcionales y por tanto deberán cumplimentarse todos los campos de los que posea información. 


\section{PROGRAMA DE PUBLICACIONES.}




\section{PROGRAMA DE PUBLICACIONES.}

\section{- Enumeración.}

El Monasterio de San Jerónimo de Granada, pretende lograr una línea de continuidad y consolidación en las distintas publicaciones que realice.

Aparte de las publicaciones generadas por la musealización del monasterio, creadas con el objetivo de difundir tanto la historia del Monasterio como el patrimonio mueble que alberga, tales como el folleto explicativo del Monasterio destinado a un visitante general, el Boletín de carácter periódico, o las publicaciones destinadas a un sector infantil, no queremos dejar a un lado la investigación, considerándola no sólo como una de las funciones del personal de la institución, sino que el Monasterio sea objeto de investigación para la gente fuera de la institución, por lo que se facilitará a los posibles investigadores toda la documentación y apoyo que necesiten tanto por parte del personal como por el patronato.

Las publicaciones que nuestra institución realizará serán:

- Folleto explicativo del Monasterio.

- Boletín del Monasterio de San Jerónimo.

- El Monasterio de San Jerónimo para los niños.

- Cuaderno de Actividades.

- Catálogos de las exposiciones temporales.

\section{- Descripción.}

\section{- Folleto explicativo del Monasterio}

Éste se entregara a todos los visitantes en el momento de adquirir su entrada, para facilitar la comprensión tanto del recorrido como del discurso que queremos explicar.

Se encargará a una empresa de diseño y reprografía la realización de un folleto explicativo con las siguientes características:

- Su tamaño real desplegado ha de tener un formato Din-A4.

- Ha de constituir un tríptico, de manera que se doble sobre si mismo dos veces, creando seis subdivisiones o espacios. 
- El grosor del papel empleado en la realización del mismo no será inferior a 120 gramos ni superior a 150 gramos, lo que facilitará la impresión.

- Las características del papel, papel con un acabado semisatinado con una resolución de tipo medio que nos permita una correcta visualización de las reproducciones fotográficas con el menor coste posible.

Del diseño y maquetación del folleto se encargará la misma empresa, aunque deberán de cumplir los siguientes objetivos:

- Cuatro imágenes a todo color representativas del Monasterio, que les serán proporcionadas, así como un gráfico interpretativo de las diferentes dependencias que también les será facilitado.

- El texto deberá ocupar entre un 50 y un $60 \%$ del total del folleto. Teniendo en cuenta que se utilizarán diferentes tipos de letra, con diversos formatos e interlineados.

\section{- Boletín del Monasterio de San Jerónimo.}

Tendrá un carácter periódico, publicándose dos veces al año, el primer número en el mes de febrero y el segundo durante el mes de septiembre. Aunque se deja abierta la posibilidad de la publicación de un número de carácter extraordinario debido a la existencia de algún acontecimiento de gran relevancia para nuestra institución.

De la coordinación del trabajo necesario para su elaboración se encargará el responsable de publicaciones, quién contará en todo momento con la colaboración del personal técnico del Monasterio, así como posibles colaboraciones externas.

El Boletín presentará las siguientes características en cuanto a su formato:

- El papel será de un grosor será de 80 gramos, cuya calidad permitirá ver las imágenes con una buena resolución pero con el menor coste posible,

-El papel será semisatinado y de grano fino,

- Las medidas de las páginas serán de 17 por 24 centímetros.

- El número de éstas oscilará en un intervalo comprendido entre 50 y 75 páginas.

- Las páginas estarán impresas a doble cara.

- Las fotografías serán en general en blanco y negro, excepto algunas que por su interés podrán ser realizadas en color. 
- Tendrá guardas de respeto, de la misma calidad que el resto del Boletín.

- Las tapas serán semirigidas, mate y de grano medio.

\section{- El Monasterio de San Jerónimo.}

Publicación destinada al colectivo infantil, su elaboración correrá a cargo del responsable técnico. La tipología será similar a la de un comic, de modo que a través de viñetas se explicará la historia del Monasterio de San Jerónimo de una forma didáctica pero muy amena y divertida.

La historia será narrada por un personaje que aparecerá en las viñetas, éste no será otro que el Gran Capitán.

El formato de la publicación presentará las siguientes características:

- Tamaño del papel Din A4.

- El papel presentará un grosor de 80 gramos.

- El papel será mate, no necesitaremos una gran resolución ni calidad del papel para la impresión, ya que utilizaremos colores puros, sin mezclas ni sombreados, ya que el resultado será más atrayente para los niños a la vez que su coste se economiza.

- Cada página constará de un número aproximado de cuatro filas y tres columnas de viñetas, pudiendo ser mermadas o aumentadas si las características del relato lo requieren.

- El número de páginas oscilará entorno a unas veinticinco.

- Las pastas de la publicación tendrán un grosor de 100 gramos, semisatinadas, con una ilustración que abarque todo el espacio de las pastas quedando el texto superpuesto.

\section{- Cuaderno de Actividades.}

Esta será una publicación dedicada al sector infantil, se entregará a los niños una vez realizada la visita, aunque también se podrá vender en la tienda del Monasterio.

La tipología de este cuaderno será similar a la de un libro de pasatiempos, ya que se pretende afianzar en los niños algunos conocimientos que se les han explicado durante sui visita, de una forma muy divertida. 
- El formato de este cuaderno presentará las siguientes características:

- El tamaño del papel será Din A5.

- El papel tendrá un grosor de 80 gramos.

- El acabado del papel será mate.

- La impresión será monocromática.

- Las pastas tendrán un grosor de 100 gramos.

A continuación incluimos algunos ejemplos de actividades.

\section{- Catálogos de la Exposiciones temporales.}

Con motivo de la celebración de exposiciones temporales se realizarán una serie de publicaciones, catálogos. Su formato y características dependerán del tipo de exposición, de las piezas expuestas, así como de su financiación. 


\section{LAS PARTES DE UN RETABLO}

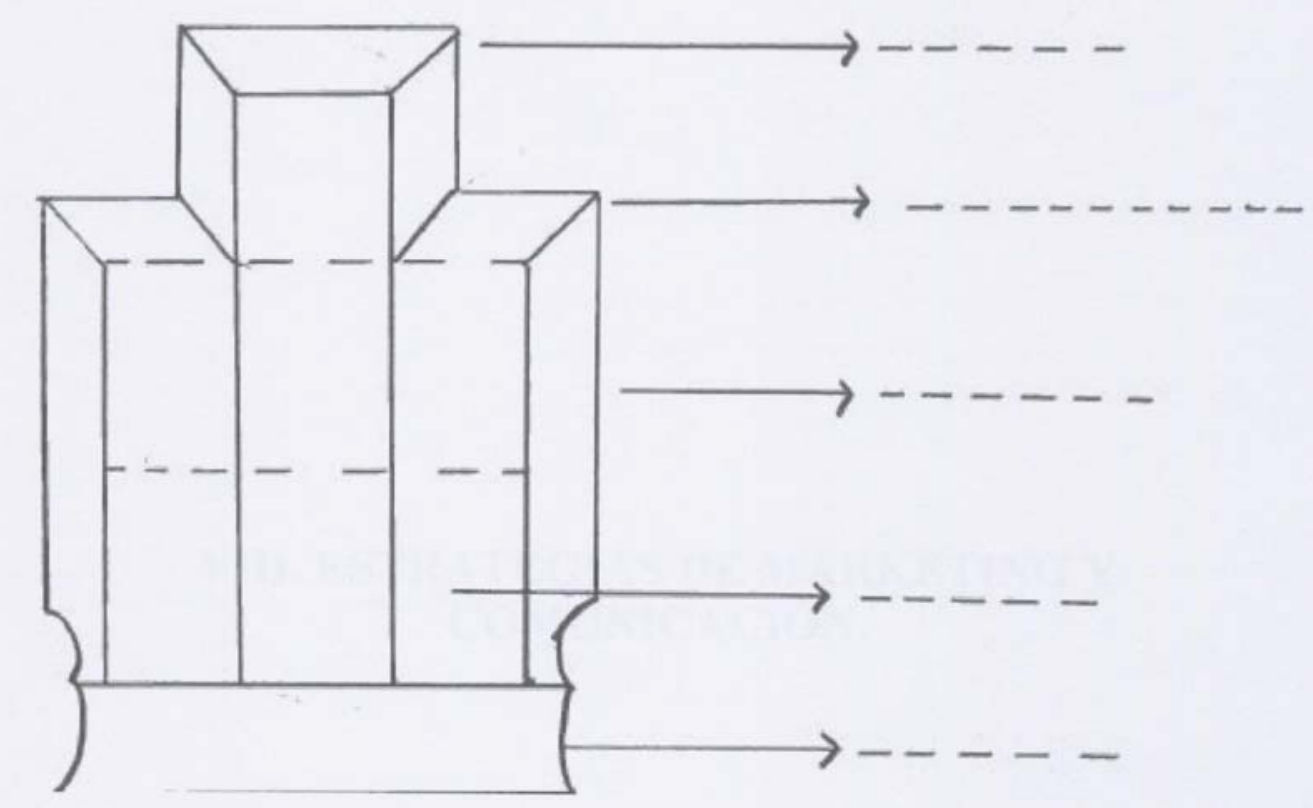

Ordena las partes de este retablo:

- Banco o predela

- Calle

- Cuerpo o piso

- Ático

Después decora, tú mismo este retablo. 
EL RETABLO es una obra realizada con piedra, madera u otras materias que componen la decoración de un altar. Retablo significa retro (detrás) y tábula (mesa), por su situación frontal puesta tras el altar. En la construcción de un retablo intervenían carpinteros y ensambladores, imagineros, canteros, escultores, herreros, cerrajeros, doradores, estofadores y pintores.

Ahora, une con una línea cada oficio con el trabajo que realizaban en el retablo:
Carpintero
- Tallan la madera
Ensambladores
- Realizan imágenes
Canteros
- Trabajan la piedra
Herreros
- Unen las piezas del retablo
Doradores
- Realizan cuadros y frescos
Pintores
- Preparan las piezas de madera
Imagineros
- Aplican el pan de oro a las piezas de madera 
COLOREA este animal.

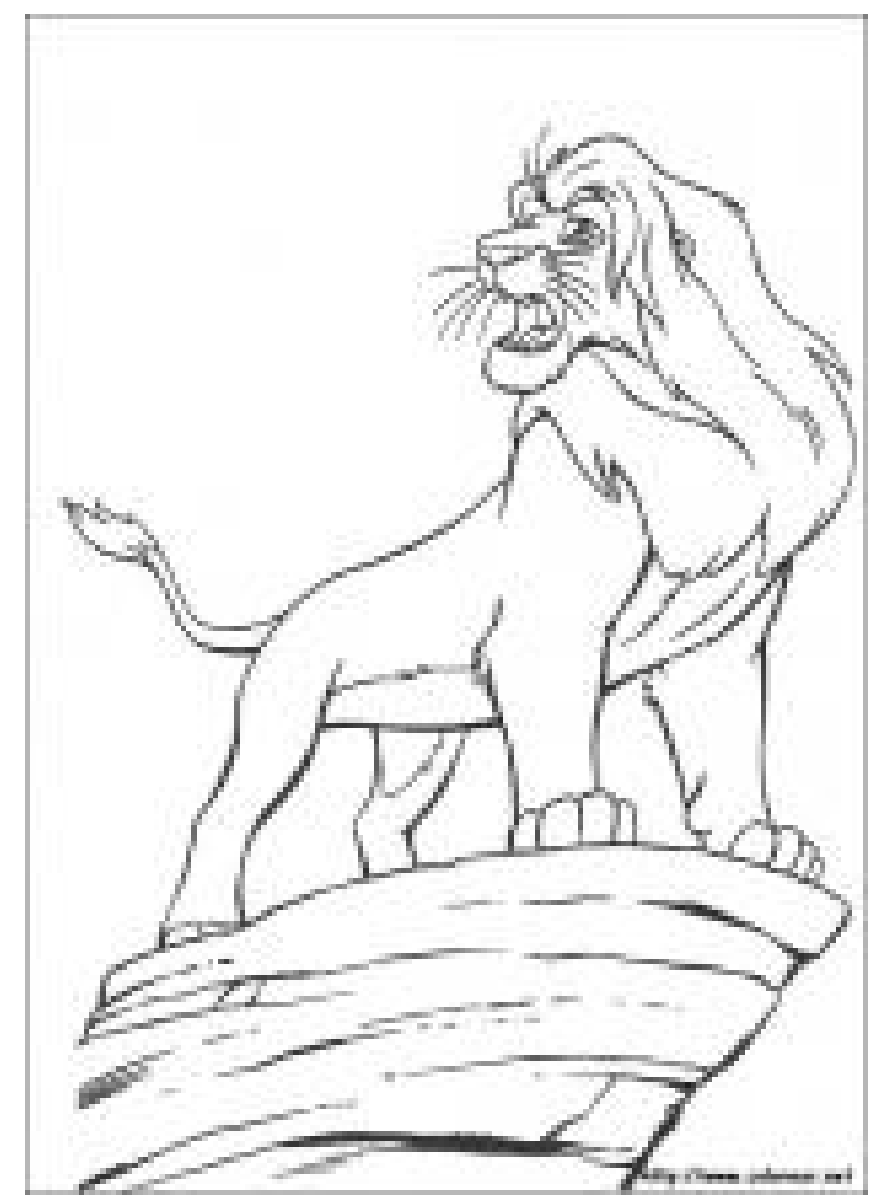

Y ahora.....

- ¿Sabes qué animal es?

- ¿Cuántos has visto en el Monasterio? ¿Dónde?

- ¿Sabes quién le curó una pata? 
VIII. ESTRATEGIAS DE MARKETING Y COMUNICACIÓN. 


\section{ESTRATEGIAS DE MARKETING Y COMUNICACIÓN.}

Hoy día el prestigio de cualquier institución museística se mide por su "audiencia", es decir, por el número de visitantes que recibe. Para aumentar el número de visitas y mejorar la calidad de ésta se están aplicando a los museos técnicas de marketing, lo que Lord y Lord" definen como "la manera de promocionar los servicios de un museo entre los visitantes reales y potenciales del mismo a base de estimular el aumento de la audiencia, la duración de la visita, de mejorar la estadía, de mejorar el grado de satisfacción obtenido de los actos, actividades y programas ofrecidos, de incrementar el gasto del visitante, etcétera, y no únicamente de hacer propaganda del museo. En definitiva, desarrollar la atención al visitante y las actividades que sirven a los objetivos del museo y motivan nuevas visitas."

Como hemos manifestado en otros apartados de este proyecto, uno de los objetivos principales de nuestra institución es atraer al mayor número posible de visitantes, ofreciéndoles los mejores servicios tendentes a la comprensión y difusión del Monasterio de San Jerónimo de Granada como museo.

Para conseguirlo, el instrumento del que debemos servirnos es el marketing, pieza fundamental de comunicación del Monasterio con el público.

Los aspectos fundamentales que debemos atender para desarrollar la campaña de marketing son:

- Conocimiento exhaustivo del público que actualmente visita el Monasterio (sexo, edad, formación, procedencia, etcétera).

- Estudio del público potencial que podría visitarnos, con previa identificación de mercados.

- Adopción continuada de medidas para la mejora del servicio al visitante, hasta tal punto que estemos sometidos a un plan de mejora continuo, ya que es primordial mantener la imagen.

El producto del marketing, el Monasterio de San Jerónimo, es lo que hay que "vender". En concreto, mostrar a ese público potencial la riqueza que tiene San Jerónimo y la posibilidad de pasar unas horas inolvidables, es decir, atraerlo y conseguir que tome la decisión de visitarnos.

Estamos pensando a quién dirigir los mensajes y explicar a cada colectivo una actuación diferente dentro de las múltiples opciones que tenemos, así:

- Folletos.

- Publicidad.

${ }^{68}$ Lord, B. y Dexter Lord, G. [1998], p. 245. 
- Mailing.

- Actividades de relaciones públicas.

- Promociones en distintos colectivos sociales, Universidad, colegios mayores, oficinas de Turismo, etcétera.

- Conferencias.

El público potencial al que puede ir destinado es muy amplio y evidentemente habrá mercados más cercanos y en teoría con más posibilidades de éxito y otros cuyos resultados serán a medio e incluso a largo plazo.

Luego, según el perfil de cada mercado o sector al que nos dirigimos, escogeremos la actuación más adecuada.

Vamos a intentar profundizar en un mercado existente y que conseguimos atraerlo no cabe dudad que supondría el éxito total de este proyecto, y la consolidación del Monasterio de San Jerónimo como un referente del turismo cultural en Andalucía. Nos referimos a la cantidad de visitantes que diariamente llegan a Granada y que abandonan la ciudad sin visitar el Monasterio.

Hagamos un paréntesis para situarnos en la realidad socioeconómica granadina. El día 6 de junio pasado fue presentado por La General es estudio $L a$ provincia de Granada en cifras (1999-2001) en el que se concluye que la economía granadina se ha consolidado en el último trienio, con un crecimiento aceptable y unos indicadores optimistas de cara al futuro.

Una de las conclusiones de este estudio es el hecho de que el crecimiento está sostenido únicamente por el sector de la construcción y el de servicios. En Cuanto una buena gestión en los últimos años ha hecho que Sierra Nevada y la Alhambra lideren los atractivos turísticos y que provoquen que se incrementen año tras año los visitantes a la ciudad de Granada.

El potencial turístico de la ciudad de Granada es enorme y además al que indudablemente ayudan o van a ayudar los siguientes factores:

- Referentes de Sierra Nevada y Alhambra.

- Infraestructuras, por fin, en ejecución de :

- Autovía de la Costa.

- Autovía Adra- Nerja.

- Conexión Ave en Bobadilla.

- Potenciación Aeropuerto. 
- Implantación del distrito abierto en las universidades, teniendo en cuenta que Granada es la más solicitada de Andalucía.

- Amplia red de establecimientos hoteleros y de restauración.

- Precios competitivos.

- Situación geográfica de Granada, distante por carretera tan sólo a:

- 1 hora de Jaén.

- 1'5 horas de Málaga.

- 2 horas de Almería

- 2 horas de Córdoba.

-2 '5 horas de Sevilla.

- 4 horas de Madrid.

- Numerosos recursos aún sin desarrollar.

Todo esto hace que reiteremos que el potencial turístico de Granada es muy esperanzador y que si conseguimos, por ejemplo, que el $25 \%$ de los visitantes de la Alhambra visiten nuestro Monasterio tendremos el éxito asegurado ya que diariamente son varios los miles de turistas que consiguen entrar en la Alhambra, agotándose el cupo de entradas prácticamente todos los días. A este público que se queda sin entradas en la Alhambra hay que ofrecerle unas alternativas culturales y una de las de gran atractivo puede ser el Monasterio de San Jerónimo.

Para captar este público nuestra campaña de marketing incidirá en:

- Agencias de viajes.

- Hoteles.

- Tour Operators.

- Oficinas de Turismo.

Con el objeto de incluir en el mismo paquete la visita al Monasterio de San Jerónimo de aquellos turistas que ya vienen a Granada con la entrada a la Alhambra desde su punto de origen.

Y finalmente, queremos hacer hincapié en el Bono Turístico, un instrumento bien diseñado con unos objetivos realmente buenos y muy interesantes para el comprador, pero que necesita terminar de implantarse y una mayor implicación, tanto de las instituciones públicas como privadas.

En la actualidad el Monasterio de San Jerónimo es uno de los monumentos que junto a la Alhambra y Generalife, Catedral, Capilla Real, Monasterio de la Cartuja, Parque de las Ciencias, Museo de Bellas Artes y Museo Arqueológico (en estos dos últimos al ser el acceso gratuito para los ciudadanos de la Unión Europea, se hace con el bono el $25 \%$ de descuento) junto con diez viajes en autobús pueden visitarse con el Bono que puede ser adquirido por 2.500 pesetas. 
Tan importante como la captación de nuevos visitantes y la apertura a otros mercados y sectores, es el mantener la imagen y un excelente servicio ya que está demostrado que el mejor marketing es el "boca a boca", un visitante muy satisfecho puede conseguirnos 5 visitantes nuevos y por el contrario uno insatisfecho puede desanimar a cualquier persona que le pregunte por el Monasterio de San Jerónimo.

Para ello analizaremos en adelante los servicios que prestemos a los distintos tipos de público que pueden visitarnos.

\section{Servicios para el público general.}

- Las entradas. Realizaremos seis modelos de entradas, en cada una de ellas aparecerá representada una imagen, un fragmento del Retablo de la capilla mayor de la iglesia, de tal forma que si se juntan todas las entradas se completará la imagen del retablo, premiando de este modo al visitante habitual.

Este modelo de entradas, irá cambiando cada dos años, eligiendo otras imágenes representativas del Monasterio.

- Visitas guiada. Se ofertarán visitas guiadas, éstas no tendrán el carácter de una conferencia, sino que serán muy flexibles, adaptándose a cada tipo de público.

- Audioguías. Permiten una visita comentada, en el idioma elegido por el usuario. Tienen la ventaja de la autonomía de la visita, pero la desventaja del aislamiento del visitante.

- La tienda del Monasterio Museo. Hay que tener en cuenta el hecho de que los productos que se ofrecen contribuyen a fortalecer la relación entre el Monasterio y el visitante. El comprador valora distintas cosas, entre las que podemos destacar, la calidad y originalidad de los productos que se ponen a la venta, el servicio dado por los dependientes de la tienda, y sobre todo la sensación de que comprando ayudan al Monasterio.

Para aumentar esta sensación, todos los productos ofrecidos llevarán una etiqueta en la que se explicará la relación que ese objeto tiene con las colecciones del Monasterio y de qué forma la compra del mismo beneficia a éste.

Además, gracias a los productos que venderemos, el Monasterio penetrará en las casas de los compradores y el producto comprado permanece como recuerdo de la visita al Monasterio.

Señalamos a continuación el listado de productos que se podrán adquirir en la tienda del Monasterio de San Jerónimo: 


\begin{tabular}{|l|l|l|}
\hline PRODUCTO & IMPORTE pesetas & IMPORTE euros \\
\hline Camiseta & 2.000 & 12.02 \\
\hline Sudadera & 3.500 & 21.04 \\
\hline Lápiz & 150 & 0.90 \\
\hline Bolígrafo & 250 & 1.50 \\
\hline Marcapáginas & 150 & 0.90 \\
\hline Taza & 1.000 & 6.01 \\
\hline Tarjeta postal normal & 50 & 0.30 \\
\hline Tarjeta postal grande & 100 & 0.60 \\
\hline Cartel 50 x 70 & 1.200 & 7.21 \\
\hline Cartel 70 x 100 & 2.000 & 12.02 \\
\hline Libreta pequeña & 600 & 3.61 \\
\hline Cuaderno & 1.100 & 6.61 \\
\hline Alfombrilla ratón & 1.000 & 6.01 \\
\hline Agenda & 2.000 & 12.02 \\
\hline Recortable del Monasterio & 700 & 4.21 \\
\hline Comic del Monasterio & 300 & 1.80 \\
\hline Boletín del Monasterio & 1.100 & 6.61 \\
\hline
\end{tabular}

Además de estos productos seguirán vendiéndose los productos que en la actualidad realiza la propia comunidad de jerónimas, así dulces, mermeladas, etcétera, sólo que intentaremos hacerlos aún más atractivos, mejorando su presentación con un nuevo diseño de los envases, etcétera.

Los productos que se venden en la tienda del Monasterio podrán ser también adquiridos en otros establecimientos, así por ejemplo en tiendas especializadas en la venta de objetos de museos, como Museum Musei en Madrid y en algunos aeropuertos españoles.

- Cesión de la iglesia del Monasterio de San Jerónimo. También pensamos que la iglesia podría cederse para la celebración de conciertos, por ejemplo, en el Festival Internacional de Música y Danza que se desarrolla en la ciudad de Granada de forma anual, durante el mes de junio. Por supuesto, la iglesia sólo se cederá para la celebración de conciertos de elevado prestigio, es decir, sólo los que ayuden a mantener una imagen prestigiosa de nuestra institución.

\section{Servicios para el público escolar.}

- Visitas guiadas. Estas estarán concertadas, y previamente se trabajará con el profesor, con el fin de preparar la visita por parte del Monasterio y por parte del colegio o centro. alumnos.

- Hojas didácticas, cuyo contenido estará acorde a la edad de los 
- Talleres. Su finalidad será la de ofrecer una lectura de la historia y de los objetos del Monasterio sin caer en el aburrimiento o cansancio, para que los alumnos se encuentren que en un museo pueden realizar actividades divertidas. Un ejemplo de actividad, a grandes rasgos, podría ser la siguiente:

\section{"Como construir un retablo"}

Esta actividad la realizarían los escolares, tras haber contemplado el Retablo de la capilla mayor de la iglesia del Monasterio.

Se realizarán unos retablos de corcho blanco o poliuretano, con unas formas muy básicas, estructurado en varias partes. Los escolares, primero dorarán el retablo, después dibujarán diversos motivos en papel que colorearán para luego pegarlos en el retablo.

- Actividades recreativas. Se organizarán actividades con un sentido lúdico y recreativo, por ejemplo, representaciones teatrales. El objetivo será conseguir que aprendan determinados conocimientos a la vez que desarrollan su imaginación y creatividad, mientras se sienten protagonistas del museo.

- Publicaciones especiales. Cuaderno de Actividades, Comic del Monasterio, etcétera. (Punto VII. de este proyecto, Programa de Publicaciones).

\section{Servicios para públicos especiales.}

- Los investigadores. Uno de los objetivos de nuestra institución es la investigación, de modo que no pondremos obstáculos a ningún investigador, aunque no pertenezca a la misma.

Se les facilitará el acceso a los fondos del Museo, tanto a las piezas expuestas como a las que se encuentren en reserva.

- Disminuidos motores. Para facilitar la visita del Monasterio Museo de San Jerónimo a este colectivo, eliminaremos las barreras arquitectónicas que presenta el edificio, así situaremos rampas en los escalones, un ascensor (estará ubicado junto a la escalera del claustro principal, en el espacio que queda entre la capilla privada de la Comunidad y el segundo claustro, este es el mejor lugar ya que no entorpece la visión del monumento), servicios para personas en silla de rueda, pavimento regular y liso, puertas que no impidan la entrada de una persona en silla de ruedas y las señalizaciones estarán situadas a una altura conveniente.

- Disminuidos visuales. Todos los textos informativos estarán a disposición de este colectivo en braille.

En la portería, se ubicará una maqueta del Monasterio de San Jerónimo, realizada con materiales de texturas diferentes que permitan un reconocimiento 
táctil a los ciegos, también se expondrá otra maqueta con las mismas características del Retablo de la capilla mayor de la iglesia.

- Disminuidos auditivos. Se ofertarán visitas concertadas a este colectivo, realizadas por un guía especial.

- Disminuidos psíquicos. Se concertarán visitas guiadas con este colectivo, se trabajará previamente con el profesor o monitor, ya que es el único que conoce las necesidades y capacidades de cada uno de sus alumnos.

La posibilidad de realizar este tipo de visitas deberá difundirse entre los centros educativos, talleres ocupacionales y las asociaciones de padres de deficientes psíquicos, con el objetivo de prepararlas de antemano en el Monasterio y en el colegio o centro. 
IX. GESTIÓN. 


\section{GESTIÓN.}

\section{Elección de un sistema, el Patronato del Monasterio de San Jerónimo.}

El monasterio seguirá siendo de propiedad privada, es decir, tanto el edificio como sus colecciones pertenecerán a la Orden Jerónima, cuya comunidad de religiosas posee la propiedad, pero la nueva institución que pretendemos crear, no podría mantenerse, desde el punto de vista económico, sólo con los ingresos por venta de entradas, etc., de ahí que elijamos un sistema privado que estará regido por un patronato o consejo. La financiación saldrá de una mezcla de fondos privados y públicos y del gasto realizado por los visitantes en el museo.

El Monasterio de San Jerónimo se incluirá dentro del Sistema Andaluz de Museos.

El monasterio estará regido por un patronato, sin ánimo de lucro, sujeto a la ley 30/1994, de 24 de noviembre, de Fundaciones e Incentivos Fiscales a la Participación Privada en Actividades de Interés General y que asuma la responsabilidad legal y financiera del museo/monasterio. Estará compuesto por un total de doce miembros, diez de ellos a título del cargo que ostentan en ese momento, y otros dos a título personal, elegidos por su trayectoria y valía profesional, serán dos personas que hayan demostrado en sus investigaciones y publicaciones, relacionadas con las colecciones y el propio monasterio, ser merecedores de este nombramiento.

\section{Su configuración y composición.}

El Patronato del Monasterio de San Jerónimo estará constituido por toda clase de bienes y derechos susceptibles de valoración económica.

La administración y disposición del patrimonio corresponderá al Patronato en la forma establecida en los Estatutos y con sujeción a lo dispuesto en la Ley $30 / 94$

El Monasterio de San Jerónimo deberá figurar como titular de todos los bienes y derechos que integran su patrimonio, los cuales harán constar en su inventario y en el Registro de Fundaciones, y se inscribirán en su caso, en los registros correspondientes.

Corresponde al Patronato, como órgano de gobierno y representación, cumplir los fines fundacionales y administrar los bienes y derechos que integran el patrimonio del Monasterio de San Jerónimo, manteniendo plenamente el rendimiento y utilidad de los mismos.

Los patronos entrarán a ejercer sus funciones después de haber aceptado expresamente el cargo en documento público o en documento privado con firma 
legitimada por notario. Dicha aceptación se inscribirá en cumplimiento de la ley en el Registro de Fundaciones.

Los patronos ejercerán su cargo gratuitamente sin que en ningún caso puedan percibir retribución por el desempeño de su función. No obstante, tendrán derecho a ser reembolsados de los gastos debidamente justificados que el desempeño de su función les ocasiones, con dietas de viajes, manutención o asistencia, según proceda.

Los miembros serán los siguientes:

- Rvda. Madre Superiora de la Comunidad de jerónimas del Real Monasterio de San Jerónimo de Granada.

- Excmo/a. Sr/a. Alcalde/Alcaldesa de la ciudad de Granada.

- Excmo/a. Sr/a. Presidente/a de la Diputación de Granada.

- Presidente/a de la Caja General de Ahorros de Granada.

- Rector/a Magnífico/a de la Universidad de Granada.

- Director/a del Monasterio de San Jerónimo de Granada.

- Excmo. y Rvdmo. Sr. Arzobispo de Granada.

- Excmo/a. Consejero/a de Cultura de la Junta de Andalucía.

- Conservador/a del Monasterio de San Jerónimo de Granada.

- Responsable la gestión financiera del Monasterio de San Jerónimo de Granada.

- Persona de reconocido prestigio.

- Persona de reconocido prestigio.

Pretendemos, al elegir estos miembros que la ciudad, así como sus instituciones, se involucren en el funcionamiento del Museo del Real Monasterio de San Jerónimo, para conseguir que uno de los edificios más significativos junto con su importante colección, pueda ser admirado y disfrutado por la ciudad, tanto ahora como por las generaciones venideras.

El patronato asumirá las siguientes responsabilidades ${ }^{69}$ :

${ }^{69}$ Lord, B. y Lord, G. D. [1998], p.33. 
1. Garantizar la continuidad de la misión, el mandato y los propósitos con los que se funda el museo.

2. Actuar como puente entre el museo y la comunidad (nacional, internacional, regional, provincial, local).

3. Preservar de daño y pérdida las colecciones del museo, así como proporcionar seguridad a las colecciones del mismo, y al personal y al público visitante, hasta el nivel exigido por la misión y el mandato del museo.

4. Garantizar que el museo sirve a un público lo más amplio posible.

5. Garantizar que el museo desarrolla programas de investigación pertinentes con el fin de crear y diseminar conocimiento objetivo y preciso.

6. Discutir y aprobar líneas de actuación consecuentes con la misión y el mandato del museo y supervisar su cumplimiento.

7. Planificar en vistas al futuro del museo, incluyendo el análisis y la aprobación de un plan estratégico que fije las metas del museo y la manera de alcanzarlas, así como de hacer el seguimiento del cumplimiento del plan.

8. Garantizar la estabilidad financiera del museo mediante el análisis, la aprobación y el seguimiento de los presupuestos y de los informes financieros, acordando auditorias regularmente, invirtiendo los activos financieros del museo y procurando obtener fondos suplementarios según las necesidades, para permitir que el museo pueda hacer frente a presentes y futuras responsabilidades financieras.

9. Contratar a un director para el museo y evaluar su gestión.

10. Asegurarse de que el museo dispone de suficiente personal para llevar a cabo todas sus funciones.

La duración de permanencia en el patronato será la misma que ostente cada miembro en su cargo en la institución a la que pertenece, sin embargo los dos miembros elegidos lo serán hasta que el resto de miembros o ellos mismos, lo consideren oportuno. Si algún miembro realizase declaraciones o actuase de forma que pusiera en entredicho o deshonrará el nombre de la Institución, este sería expulsado del Patronato inmediatamente.

El Patronato se reunirá tres veces al año, una vez cada cuatro meses, por ejemplo, primer jueves del mes de enero, primer jueves del mes de mayo y primer jueves del mes de septiembre. Todos los miembros tienen la obligación y el deber de asistir a las reuniones, éstas se celebrarán de forma privada, es decir, no estarán abiertas al acceso de público. 
En caso de que se necesite aprobar alguna cuestión, será necesaria una mayoría de las dos terceras partes, es decir, ocho miembros.

Se elegirá un Presidente, un Secretario y un Tesorero.

\section{Fórmulas de participación social.}

Como fórmula de participación social entendemos como más idónea la creación de una asociación de amigos, la Asociación de Amigos del Monasterio de San Jerónimo.

La labor a desarrollar por el Presidente será:

- Apoyar totalmente al grupo de entusiastas del Monasterio de San Jerónimo que quieran formar parte de la asociación.

- Buscar el respaldo de otras instituciones o personas físicas con influencia local.

- Proporcionar ayuda económica para los gastos de puesta en funcionamiento de la asociación.

- Ofrecer una relación de actividades en las que los amigos podrían obtener ventajas o beneficios que los animarán a su inscripción. Algunas de éstas podrían ser:

- Acceso gratuito al Monasterio de San Jerónimo.

- Descuentos en la tienda del Monasterio de San Jerónimo.

- Envío a domicilio de programas de información.

- Invitación a conferencias y cursos.

- Bonificación en la entrada a otros museos.

- Invitación a la inauguración de las exposiciones temporales.

Las ventajas que reportaría a nuestra institución la Asociación de Amigos del Monasterio de San Jerónimo sería entre otras la de disponer de un grupo de personal que aporten entusiasmo y ganas de trabajar y conseguir así un voluntariado que constituye una fuente de mano de obra gratuita a disposición del Museo del Monasterio, totalmente necesaria en muchos eventos y que el presupuesto no puede abarcar, encajando así con el aumento progresivo de la participación de la sociedad civil en la vida de las instituciones culturales. 
X. EL PERSONAL. 


\section{EL PERSONAL.}

La estructura orgánica del personal del Monasterio se hará en base a tres grandes áreas, además de la Dirección, éstas serán:

- Conservación e investigación.

- Difusión.

- Administración.

A continuación, vamos a ver cada área de un modo más detenido, indicando las funciones que cada miembro del personal de nuestra institución deberá llevar a cabo, basándonos en el Reglamento de los Museos de Titularidad Estatal y del Sistema Español de Museos del año 1987.

\section{Dirección.}

Un Director. Nombrado por el Patronato, quien delega en él la responsabilidad de todo el personal, así como del buen funcionamiento diario de la institución. El perfil será el de un titulado universitario en la materia afín a la temática del museo, es decir, un licenciado en Geografía e Historia, especialidad Historia del Arte o un licenciado en Historia del Arte. Deberá poseer amplios conocimientos relacionados con la función del museo, así como de la legislación en materia de museos y patrimonio, en general, además deberá de demostrar amplia experiencia tanto en la gestión como en la administración en el sector cultural.

Sus funciones serán:

- Llevar a cabo los objetivos de la institución.

- Ejercer el liderazgo a través del conocimiento especializado del mandato de la institución.

- Recomendar políticas y planes, y la necesidad de su revisión, al patronato.

- Desarrollar las políticas y los planes aprobados por el patronato.

- Informar sobre la ejecución de las políticas y los planes aprobados por el patronato.

- Planificar, organizar y diseñar la plantilla de personal de la institución. 
- Dirigir y coordinar el funcionamiento diario del personal de la institución.

- La gestión financiera de la institución.

- Adoptar las medidas necesarias para la seguridad del patrimonio custodiado por en la institución.

- Las relaciones institucionales con la Administración, con la comunidad académica y con el sector privado en interés de la institución.

\section{2. Área de Conservación e Investigación.}

"El área de conservación e investigación abarcará las funciones de identificación, control científico, preservación y tratamiento de los fondos del Museo y de seguimiento de la acción cultural del mismo.

Se encuadrarán en esta área las actividades tendentes a:

- La elaboración de los instrumentos de descripción precisos para el análisis cientifico de los fondos.

- El examen técnico y analítico correspondiente a los programas de preservación, rehabilitación y restauración pertinentes.

- La elaboración y ejecución de programas de investigación en el ámbito de la especialidad del Museo.

- La redacción de las publicaciones científicas y divulgativas del Museo $^{70}$.

El personal englobado en esta área será el siguiente:

Un conservador. Deberá tener una titulación universitaria relacionada con las colecciones, es decir, licenciado en Geografía e Historia, especialidad Historia del Arte o licenciado en Historia del Arte. Además se tendrá muy en cuenta la especialización en, al menos, una de las temáticas del museo, así pintura o escultura de los siglos XVI, XVII o XVIII. Probará su experiencia en la gestión de museos o equipamientos similares, así como su participación en proyectos de investigación y evidencia de publicaciones. También tendrá conocimientos de técnicas de selección, evaluación, preservación, restauración y exposición de objetos, así como conocimientos sobre el mercado de objetos culturales, de los

${ }^{70}$ Reglamento de los Museos de Titularidad Estatal y del Sistema Español de Museos, art. 18. 
principios éticos del coleccionismo y de la legislación vigente sobre importación y exportación.

Sus funciones serán:

- La seguridad, preservación, documentación e interpretación de todas las colecciones.

- Las recomendaciones sobre adquisiciones.

- El diseño y ejecución de un programa de investigación sobre la colección.

- La investigación de las colecciones, tanto general como de aspectos específicos, y la publicación de los resultados de una forma accesible para los visitantes y los usuarios del museo.

- El asesoramiento en la producción de exposiciones permanentes y temporales.

- El asesoramiento en la producción de actividades para el público.

- El desarrollo de proyectos de investigación y exposiciones en colaboración con otras instituciones.

- La selección de programas informáticos que cubran las necesidades de gestión de las colecciones.

Un conservador, responsable del sistema de documentación. Tendrá una titulación universitaria en Geografía e Historia, especialidad Historia del Arte, en Historia del Arte o Humanidades. Probada experiencia en el desarrollo de procedimientos de catalogación y en la gestión de archivos y base de datos, así como conocimientos en técnicas fotográficas y en la técnica de digitalización de imágenes. Se preferirá que posea conocimientos de la temática de las colecciones del museo y se valorará la experiencia en el área de documentación de un museo o de una institución similar.

Sus funciones serán:

- Mantener los sistemas de documentación adecuados para la gestión de las colecciones.

- Supervisar, numerar, inventariar y catalogar las colecciones del museo. 
- Introducir información descriptiva e indexada dentro de la base de datos de la gestión de las colecciones.

- Mantener la base de datos desde el punto de vista de la comprobación de la terminología y de la validación de los datos.

- Integrar la base de datos de las colecciones del museo en las redes nacionales o internacionales.

- Gestionar y proporcionar las solicitudes de información sobre la colección, tanto internas como externas, incluyendo las relacionadas con el conservador.

- Preservar y mantener el archivo fotográfico.

- La reproducción fotográfica de las colecciones y de detalles de objetos propios o en préstamo, para la documentación del museo y para la investigación y publicación por parte del personal de la institución.

- La digitalización de las colecciones y su integración en la base de datos del museo.

Un restaurador. Tendrá una titulación universitaria en Restauración o en Bellas Artes, especialidad de Restauración, o podrá ser un diplomado universitario por la Escuela Oficial de Conservación y Restauración de Bienes Culturales, especialidad Escultura y/o pintura d caballete. Teniéndose muy en cuenta la experiencia en escultura y pintura de los siglos, XVI, XVII y XVIII. También se valorará mucho la experiencia en restauración en instituciones museísticas.

Sus funciones serán:

- La buena preservación de todos los objetos que forman parte de la colección.

- El examen y el tratamiento de la colección.

- El seguimiento, registro y mantenimiento de las condiciones ambientales de la colección.

- La preparación de informes sobre el estado de los objetos de la colección y de los objetos en préstamo.

Un Bibliotecario, responsable de la Biblioteca. Será titulado universitario en biblioteconomía, así como cierta formación complementaria sobre la temática 
del museo. Se tendrá en cuenta la experiencia en bibliotecas de museos o en bibliotecas especializadas, en la gestión de información en organizaciones de carácter cultural o vinculadas a la investigación y los conocimientos de todos los servicios de apoyo requeridos, especialmente en los recursos informáticos. Se valorará mucho su capacidad de comunicación y excelentes aptitudes de atención al público.

Sus funciones serán:

- El desarrollo y gestión de la biblioteca del museo.

- Proporcionar servicios de biblioteca a todo el personal.

- Llevar a cabo servicios como selección, compra o adquisición, catalogación y clasificación, circulación de los materiales impresos y sobre cualquier otro soporte.

- Coordinar el acceso del público a la biblioteca y el uso de ésta.

- Gestionar las solicitudes de información por parte del público.

- La relación con otras instituciones similares y servicios de información.

- Proporcionar referencias y asesoramiento a los usuarios de la biblioteca.

\section{3. Área de Difusión.}

"El área de difusión atenderá todos los aspectos relativos a la exhibición y montaje de los fondos en condiciones que permitan el logro de los objetivos de comunicación, contemplación y educación encomendados al Museo.

Su actividad tendrá por finalidad el acercamiento a la sociedad mediante métodos didácticos de exposición, la aplicación de técnicas de comunicación y la organización de actividades complementarias tendentes a estos fines. ${ }^{71}$

Las personas que desempeñarán su trabajo en esta área serán las siguientes:

Responsable del Departamento de Educación y Acción Cultural. Deberá ser titulado universitario en educación, pedagogía o psicopedagogía. Deberá tener experiencia en el departamento de educación de un museo o en una institución similar, así como conocer los objetivos y currículos del sistema educativo. También tendrá conocimiento de la temática de las colecciones de la

${ }^{71}$ Reglamento de los Museos de Titularidad Estatal y del Sistema Español de Museos, art. 19. 
institución y de los métodos de evaluación, así como del diseño, ejecución e interpretación de los estudios del público y las encuestas.

Sus funciones serán:

- Recepción y orientación de los visitantes.

- Información mediante una correcta señalización del edificio.

- Gestión de las solicitudes de información sobre actos y programas por parte de los visitantes.

- El acceso y la asistencia de los visitantes discapacitados.

- La planificación y la supervisión del personal al servicio de los visitantes.

- El seguimiento de la calidad de la visita en colaboración con el responsable de las actividades.

- La gestión de los comentarios y quejas de los visitantes.

- El diseño y la comunicación de los programas para grupos escolares.

- La preparación de los materiales y demás recursos para los programas de actividades escolares.

- La relación con profesores e instituciones escolares.

- La coordinación de los guías voluntarios.

- La formación y evaluación de los guías voluntarios.

- La realización de los programas de visitas.

Responsable de publicaciones. Al considerar excesivo para un museo del tipo del que planteamos, una persona cuyo trabajo exclusivo sea la coordinación de publicaciones, las personas que se encargarán de esta labor en nuestra institución serán los conservadores, tanto el responsable de la colección como el de la documentación y el responsable del Departamento de Educación y Acción Cultural.

Sus funciones serán: 
- Coordinar y supervisar todos los materiales impresos producidos por la institución, así, informes, libros, catálogos, guías, materiales de enseñanza, catálogos, revistas de investigación, $\mathrm{y}$ todas obras de referencia históricas, fotográficas y gráficas.

- Editar todos los materiales y realizar las correcciones y revisiones lingüísticas, gramaticales y estilísticas que se precisen.

- Reflejar la imagen deseada de la institución en todos los proyectos de diseño gráfico.

- La consecución de los objetivos de ingresos planteados.

- La publicación, en soporte no impreso, así vídeo, CD-ROM, o Internet.

- La distribución de los materiales y determinar los circuitos de circulación

\section{4.Área de Administración.}

"Se integran en el área de administración las funciones relativas al tratamiento administrativo de los fondos del Museo, a la seguridad de éstos y las derivadas de la gestión económico-administrativa y del régimen interior del Museo". ${ }^{72}$

Un administrativo. Deberá ser titulado en formación profesional de segundo grado o diplomado universitario. Además deberá tener experiencia en gestión económica y de personal.

Sus funciones serán:

- Gestión de toda la documentación administrativa de la institución.

- Mantenimiento archivo administrativo de la institución.

- Confección de las nominas del personal.

- Control de suministros.

${ }^{72}$ Reglamento de los Museos de Titularidad Estatal y del Sistema Español de Museos, art. 20. 
- Documentación económica sobre los amigos o socios del museo, sobre dotaciones y sobre los fondos provenientes del patrocinio.

- Mantenimiento y seguimiento e información sobre el presupuesto.

- Informar regularmente sobre el estado de las cuentas.

Un responsable de personal. Titulación en gestión de recursos humanos o formación equivalente. Experiencia previa en un departamento de gestión de personal $o$ recursos humanos en un museo $u$ otra organización similar, conocimiento de programas de tratamiento de textos y de sistemas de procesos de datos.

Sus funciones serán:

- Contribuir a la creación de políticas relacionadas con los puestos de trabajo y la seguridad de todo el personal, y de las condiciones que corresponda.

- Desarrollo y administración de las políticas de formación profesional.

- Gestión y seguimiento de los temas de salud y mutualidades o seguridad social del personal del museo.

- Gestión de los turnos de trabajo del personal encargado de la vigilancia de las salas, taquillas y tienda.

- Actualización de la documentación, correspondencia y transmisión de la información relativa a quienes forman la relación de puestos de trabajo.

Dos recepcionistas o encargados de taquillas e información. Deberán de tener estudios de formación profesional o equivalente, demostrar un conocimiento e interés sobre la temática de la institución, se valorará la experiencia en ventas o como cajero. Pero sobre todo se valorará la capacidad de comunicación y el dominio a nivel hablado de otros idiomas.

Sus funciones serán:

- Dar la bienvenida a los visitantes.

- Orientar e informar a los visitantes.

- Recoger información sobre los visitantes. 
- La venta de entradas y la admisión de los visitantes.

Un jefe de seguridad. Deberá tener estudios de bachillerato, formación profesional o formación equivalente. Experiencia en ámbitos relacionados con la seguridad, policía, bomberos o afines, conocimiento de los sistemas de circuitos cerrados de televisión, alarmas contra intrusos y contra incendios. Además se valorará la experiencia administrativa y la experiencia en museos $u$ otros equipamientos públicos.

Sus funciones serán:

- La seguridad del edificio y de las colecciones.

- La seguridad de los visitantes, del personal y de las demás personas en el edificio.

- El mantenimiento de las grabaciones y de las cintas de seguridad.

- El manejo y seguimiento de los sistemas de vigilancia a través de circuitos cerrados de televisión.

- El mantenimiento de la alarma contra incendios y de los demás sistemas disuasorios.

- La planificación y ejecución de respuestas ante emergencias de cualquier tipo.

- La supervisión y el establecimiento de los turnos de los vigilantes.

14 Vigilantes. (Siete en cada turno). Deberán demostrar una buena capacidad de comunicación, al estar en contacto directo con el visitante, quién normalmente recurre a ellos. Tendrán conocimiento del correcto manejo de los sistemas del circuito cerrado de televisión, y de las alarmas contra incendios y contra intrusos.

Sus funciones serán:

- La vigilancia de las zonas de exposición.

- La vigilancia de los visitantes y demás personas dentro del museo. 
- El seguimiento de las pantallas del circuito cerrado de televisión.

- La admisión de visitantes, plantilla y personal de reparto.

- Dar respuesta a cualquier emergencia.

Dos encargados o dependientes de la tienda. (Uno en cada turno). Deberán tener amplia experiencia y capacidad probada en ventas al público, preferiblemente en in equipamiento cultural o institución similar.

Sus funciones serán:

- Cumplir los objetivos de ventas e ingresos.

- La promoción y venta del "merchandaising" del museo.

- Mantenimiento de la documentación de compras y ventas.

- La gestión del inventario.

- El seguimiento de las ventas y las promociones.

- La organización de la tienda.

- La adquisición de existencias, (siempre sujeto a la aprobación del director o del conservador).

- Almacenar y poner los precios a los productos.

- La venta al público.

Un operario y encargado de mantenimiento. Deberá de probar un conocimiento del equipo y de las técnicas de limpieza que se adapten a las exigencias de la institución. Valorándose la experiencia en el mantenimiento de museos u otros equipamientos similares.

Sus funciones serán:

- La limpieza de todo lo no relacionado con la colección en las áreas de la exposición.

- La limpieza de las demás zonas del edificio.

- La retirada de basuras. 
- La reposición de bombillas, luces, etc.

- Las reposiciones en los aseos y en los puestos de primeros auxilios.

Toda esta relación de personas compone la plantilla fija de la institución, aunque se prevé la posibilidad de realizar contratos temporales para sustituir al personal fijo, cuando éste se encuentre fuera por diversos motivos, así vacaciones, enfermedad, etcétera.

Además se recurrirá a contrataciones con empresas externas a la institución en caso de que se necesite más personal, así empresas de seguridad, de limpieza, de

restauración, etcétera. 
XI. BALANCE PRESUPUESTARIO. 


\section{BALANCE PRESUPUESTARIO}

Independientemente de la financiación, de la que trataremos detenidamente en el siguiente epígrafe, tenemos que abordar cuales serán los costes de apertura y al mismo tiempo efectuar una aproximación a los costes de mantenimiento.

\section{Aproximación presupuestaria al gasto de apertura.}

En este presupuesto, la partida más importante es la que corresponde a la rehabilitación del edificio, muy necesaria no sólo para poder albergar en él un museo sino para devolver al patrimonio histórico cultural granadino una de sus joyas más emblemáticas.

Para la obra se utilizarán todos los medios y técnicas necesarias, se adjudicará un concurso, realizado a nivel nacional, a una empresa especializada.

Los otros capítulos que encarecen el presupuesto son iluminación, climatización y seguridad. Tanto la iluminación como la seguridad son aspectos fundamentales para cualquier institución de nuestras características, por lo que habrá que realizar una inversión de una calidad contrastada. Respecto a la climatización, aunque el coste es muy elevado, habrá que efectuarlo, ya que una climatización eficaz consigue que aseguremos un buen estado de conservación del edificio y de las colecciones que éste alberga. Además, a medio y a largo plazo se convierte en un ahorro importante para los costes de mantenimiento.

El resto de partidas son el resultado del coste aproximado de lo que consideramos necesario para la apertura del Monasterio y Museo de San Jerónimo.

\section{Aproximación al coste de mantenimiento.}

Hemos separado los gastos de personal del gasto corriente, por la importancia que tiene el primero dentro del presupuesto, y por detallar todos los puestos de trabajo y su coste.

En cuanto a las distintas partidas, destaca por el coste el suministro de energía, aunque debemos tener en cuenta que aquí no sólo entra el gasto en iluminación, sino también en seguridad y climatización.

También destaca la partida de reparación del edificio, ya que, a pesar de la rehabilitación que se lleve a cabo, la extensión del mismo hace inevitable que se produzcan necesarias obras de mantenimiento.

En las siguientes tablas podemos ver estos presupuestos de una forma más detallada. 
1. COSTE DE APERTURA.

\begin{tabular}{|l|l|l|}
\hline CONCEPTO & IMPORTE pesetas & IMPORTE euros \\
\hline Rehabilitación edificio & 500.000 .000 & 3.005 .169 \\
\hline Sistema de iluminación & 80.000 .000 & 480.827 \\
\hline Sistema de climatización & 100.000 .000 & 601.034 \\
\hline Sistema de seguridad & 60.000 .000 & 360.620 \\
\hline Señalética & 2.000 .000 & 12.021 \\
\hline Audiovisual & 1.000 .000 & 6.010 \\
\hline Audioguías & 3.000 .000 & 18.031 \\
\hline Material de oficina & 2.000 .000 & 12.021 \\
\hline Material informático & 5.000 .000 & 30.052 \\
\hline Biblioteca & 10.000 .000 & 60.103 \\
\hline Vitrinas & 2.000 .000 & 12.021 \\
\hline Paneles & 1.000 .000 & 6.010 \\
\hline Telefonía & 3.000 .000 & 18.031 \\
\hline Taller de restauración & 5.000 .000 & 30.052 \\
\hline Trípticos & 1.000 .000 & 6.010 \\
\hline Mobiliario & 30.000 .000 & 180.310 \\
\hline & & \\
TOTAL & 805.000 .000 pesetas & 4.838 .322 euros \\
\hline
\end{tabular}


2. a. COSTE DE MANTENIMIENTO.

\begin{tabular}{|l|l|l|}
\hline CONCEPTO & IMPORTE pesetas & IMPORTE euros \\
\hline Reparación del edificio & 1.500 .000 & 9.016 \\
\hline $\begin{array}{l}\text { Reparación del mobiliario y otros } \\
\text { Enseres }\end{array}$ & 700.000 & 4.207 \\
\hline Material de oficina ordinario & 400.000 & 2.404 \\
\hline Material informático & 85.000 & 511 \\
\hline $\begin{array}{l}\text { Prensa, revistas, libros y otras } \\
\text { publicaciones }\end{array}$ & 1.000 .000 & 6.010 \\
\hline Publicidad & 600.000 & 3.606 \\
\hline Suministro de agua & 400.000 & 2.404 \\
\hline Suministro de energía eléctrica & 7.000 .000 & 42.072 \\
\hline Suministro de vestuario & 500.000 & 3.005 \\
\hline $\begin{array}{l}\text { Suministro de productos } \\
\text { farmacéuticos }\end{array}$ & 25.000 & 151 \\
\hline Comunicaciones telefónicas & 1.000 .000 & 6.010 \\
\hline Otras comunicaciones & 50.000 & 301 \\
\hline Productos de limpieza & 200.000 & 1.202 \\
\hline TOTAL & 13.460 .000 pesetas & 80.899 euros \\
\hline
\end{tabular}




\section{2. b. COSTE DE PERSONAL.}

\begin{tabular}{|l|l|l|l|l|}
\hline CONCEPTO & $\begin{array}{l}\text { IMPORTE } \\
\text { pesetas }\end{array}$ & $\begin{array}{l}\text { IMPORTE } \\
\text { euros }\end{array}$ & $\begin{array}{l}\text { TOTAL } \\
\text { pesetas }\end{array}$ & $\begin{array}{l}\text { TOTAL } \\
\text { euros }\end{array}$ \\
\hline Dirección & 5.356 .272 & 32.193 & 5.356 .272 & 32.193 \\
\hline Conservador (Colecciones) & 3.923 .964 & 23.584 & 3.923 .964 & 23.584 \\
\hline Restaurador & 3.346 .680 & 20.115 & 3.346 .680 & 20.115 \\
\hline Conservador (Document.) & 3.923 .964 & 23.584 & 3.923 .964 & 23.584 \\
\hline Bibliotecario & 3.310 .584 & 19.898 & 3.310 .584 & 19.898 \\
\hline Responsable D.E.A.C & 3.310 .584 & 19.898 & 3.310 .584 & 19.898 \\
\hline Responsable del personal & 3.310 .584 & 19.898 & 3.310 .584 & 19.898 \\
\hline Administrativo & 2.405 .580 & 14.458 & 2.405 .580 & 14.458 \\
\hline Recepcionista & 2.352 .504 & 14.139 & 4.705 .008 & 28.279 \\
\hline Jefe de seguridad & 2.980 .610 & 17.914 & 2.980 .610 & 17.914 \\
\hline Vigilante de sala & 2.124 .948 & 12.272 & 29.749 .272 & 178.803 \\
\hline Dependiente de tienda & 2.057 .052 & 12.364 & 4.114 .104 & 24.728 \\
\hline Operario de mantenimiento & 1.938 .564 & 11.651 & 1.938 .564 & 11.651 \\
\hline Total & & & 72.375 .770 & 435.003 \\
\hline 30\% Seguridad Social & & & 21.212 .731 & 130.500 \\
\hline TOTAL & & & 94.088 .501 & 565.503 \\
\hline
\end{tabular}

\begin{tabular}{|l|l|l|}
\hline TOTAL GASTO CORRIENTE & 94.088 .501 pesetas & 565.503 euros \\
\hline
\end{tabular}


XII. LA FINANCIACIÓN. 


\section{LA FINANCIACIÓN.}

La financiación del Monasterio de San Jerónimo deberá realizarse de tal forma que se consigan unos objetivos que consideramos fundamentales:

- Estabilidad financiera.

- Independencia económica.

- Autosuficiencia financiera.

Teniendo en cuenta que la estabilidad financiera es una meta a conseguir por todos los gestores de museos, no debemos olvidar que debemos solucionar las necesidades económicas de nuestro Monasterio y al mismo tiempo lograr que se cumplan sus objetivos y funciones. De ahí, que tengamos que generar los recursos suficientes para dar un óptimo servicio al público, potenciando la investigación y consiguiendo unas instalaciones para disfrute y conocimiento del público.

La gestión económica y financiera deberá incidir principalmente en los siguientes apartados:

- Control financiero:

- Preparación de los presupuestos.

- Seguimiento de los presupuestos.

- Generación de gastos.

- Control de gastos.

- Gestión de riesgos.

- Planificación financiera y desarrollo.

- Los presupuestos.

Se elaborarán los siguientes presupuestos:

- Presupuesto corriente, es el presupuesto anual de ingresos y gastos correspondiente a la custodia de las colecciones, actividades y al uso y mantenimiento de las instalaciones. En este presupuesto, se incluye la partida de personal. 
- Presupuesto de inversiones, son las cantidades reservadas para realizar mejoras y ampliaciones de las instalaciones del Monasterio.

En los próximos ejercicios y si así fuese necesario se realizarían presupuestos para proyectos subvencionados, fondos y dotes.

\section{- Generación de ingresos.}

Partiendo de la base de que las actividades propias del Monasterio serán en sí mismas generadoras de ingresos, deberemos aprovechar al máximo ese potencial, ya que junto con las ayudas y subvenciones totalizarán nuestros ingresos.

Los ingresos propios que tendrá el Monasterio de San Jerónimo serán:

- Ingresos por taquilla. Al fijar el precio de la visita en 700 pesetas, es decir, 4.21 euros, se ha tenido en cuenta el precio de los distintos monumentos o museos de la ciudad para hacerlo competitivo, así:

\begin{tabular}{|l|l|l|}
\hline \multicolumn{1}{|c|}{ Institución } & Costo entrada (pesetas) & Costo entrada (euros) \\
\hline Alhambra & 1.000 & 6.01 \\
\hline Catedral & 350 & 2.10 \\
\hline Capilla Real & 350 & 2.10 \\
\hline Parque de las Ciencias & 700 & 4.21 \\
\hline
\end{tabular}

Al mismo tiempo, la tarifa general contempla distintos descuentos para grupos, miembros del ICOM, familias, pensionistas, niños, etcétera, con el objetivo de poder dar respuesta a la demanda de distintos colectivos y conseguir una mayor difusión.

- Comercialización de productos. La obtención de ingresos a través de la venta de productos supone en la actualidad una importante aportación en todos los museos, ingresos que además están en un continuo crecimiento. Para garantizarnos unos ingresos significativos hemos tenido en cuenta que:

- El visitante que ha disfrutado de su visita, quiere comprar algo que le haga recordar el Monasterio y tener la posibilidad de mostrarlo a familiares y amigos.

- La gama de productos debe ser muy variada, con artículos y precios que permitan llegar a todos los visitantes. (La relación detallada de productos ya la señalamos al hablar de la mercadotecnia del Monasterio de San Jerónimo).

- Hay que ofertar una calidad contrastada en productos, prestaciones y servicios. 
En este apartado seremos ambiciosos y esperamos que el gasto medio por visitante sea de 500 pesetas, es decir, 3,01 euros.

- Alquiler de la iglesia, ésta podrá ser alquilada para la celebración de conciertos de música clásica, así por ejemplo los que se desarrollan durante el Festival Internacional de Música y Danza.

Una vez analizados los ingresos propios vamos a profundizar en los ajenos, o más concretamente, en las ayudas y subvenciones.

Es un hecho, que muchos museos reciben de la Administración a través de subsidios o subvenciones una aportación que supone entre un 70 y un $100 \%$ de todos los ingresos. Esto es así porque las distintas administraciones contribuyen con fondos públicos, vía impuestos a garantizar la preservación de un patrimonio común, a proporcionar a la sociedad una educación sobre los valores y significado del patrimonio natural y común y a potenciar un sector importantísimo en el área turística, como es el turismo cultural.

En cuanto a la aportación que realizarán las distintas instituciones nos inclinamos por el subsidio ya que la subvención va en detrimento de una planificación financiera y presupuestaria.

Las tres fuentes de ingresos ajenos serán:

- Aportaciones de los patronos:
Administración. $.80 \%$
Caja General de Ahorros de Granada.........10\%
Diputación $.5 \%$
Ayuntamiento $.5 \%$

- Subvenciones para proyectos, que se solicitarán en el momento oportuno para proyectos concretos.

- Patrocinio, para financiar las exposiciones temporales o programas concretos de actuación acudiremos al patrocinio de entidades privadas (La General, Puleva, Cervezas Alhambra, El Corte Inglés...) con las que estableceremos convenios para tener aseguradas las aportaciones y por lo tanto poder planificar las actividades.

\section{- Control de gastos.}

Con el objeto de administrar el presupuesto se harán necesarios una serie de controles y actuaciones, entre los que destacamos: 
- Todos los responsables del Monasterio tendrán asignada una cuantía económica a la que tendrán que ajustarse, cualquier gasto por encima de ese nivel necesitará autorización del director o del patronato.

- Para evitar posibles desviaciones y poder atajarlas a tiempo hay que implantar un sistema informático que permita un seguimiento, a tiempo real, de cada departamento y celebrar cada quince días con los responsables una reunión de control presupuestario.

- Respecto a las compras a proveedores de todo tipo, habrá que realizarlas mediante concurso de ofertas, aunque no siempre se valorará como más interesante la que sea económicamente. Será necesario introducir correcciones de calidad para que la imagen y los servicios no se deteriore.

- Finalmente, se auditarán, tanto los gastos como los ingresos según la normativa vigente.

\section{- Gestión de riesgos.}

Si tenemos en cuenta que la destrucción o sustracción del patrimonio atenta contra la continuidad de nuestra institución, hay que transferir la responsabilidad financiera de los riesgos mediante la contratación de los seguros necesarios.

\section{- Planificación financiera y desarrollo.}

El futuro económico de la institución se planificará a largo plazo para:

- Asegurar la estabilidad financiera de la institución.

- No perder el elemento esencial del Monasterio de "educación”.

- Contribuir a que siga siendo un recurso de turismo cultural.

- Extenderlo a todos los sectores posibles de la sociedad. 


\section{EJECUCIÓN.}




\section{EJECUCIÓN.}

Una vez aprobado el proyecto arquitectónico, la ejecución para la musealización y puesta en valor del Monasterio de San Jerónimo de Granada, se encargará a una empresa nacional mediante concurso.

La intervención se llevará a cabo en dieciséis meses, comenzando el día 28 de mayo del año 2002 y terminando el 28 de septiembre del año siguiente. La nueva institución será inaugurada el 30 de septiembre, día de San Jerónimo, del año 2003.

Los plazos, de las distintas fases de la ejecución del proyecto, se indican en el planning que adjuntamos. 


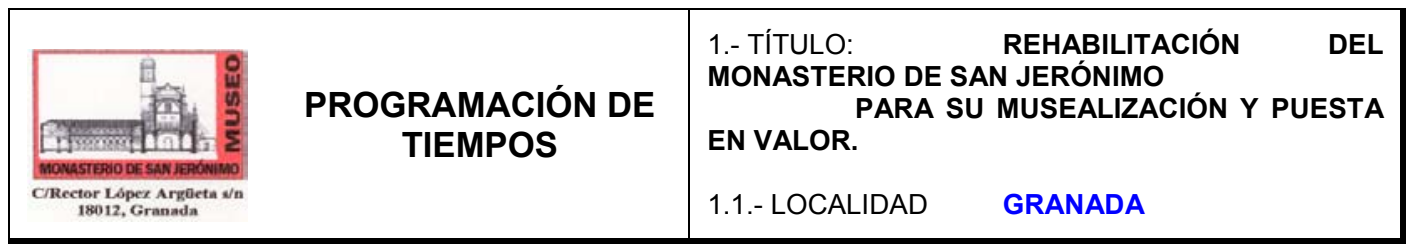

\begin{tabular}{|c|c|c|c|c|c|c|c|c|c|c|c|c|c|c|c|c|c|}
\hline \multirow{2}{*}{$\begin{array}{l}\text { DIAGRAMA DE } \\
\text { BARRAS }\end{array}$} & AÑO & \multirow[b]{2}{*}{1} & \multirow[b]{2}{*}{2} & \multirow[b]{2}{*}{3} & \multirow[b]{2}{*}{4} & \multirow[b]{2}{*}{5} & \multirow[b]{2}{*}{6} & \multirow[b]{2}{*}{7} & \multirow[b]{2}{*}{8} & \multirow[b]{2}{*}{9} & \multirow[b]{2}{*}{10} & \multirow[b]{2}{*}{11} & \multirow[b]{2}{*}{12} & \multirow[b]{2}{*}{13} & \multirow[b]{2}{*}{14} & \multirow[b]{2}{*}{15} & \multirow[b]{2}{*}{16} \\
\hline & Meses & & & & & & & & & & & & & & & & \\
\hline \multicolumn{18}{|l|}{ 1.- ESTRUCTURA } \\
\hline \multicolumn{18}{|l|}{ 2.- ALBAÑILERÍA } \\
\hline \multicolumn{18}{|l|}{ 3.- CUBIERTAS } \\
\hline \multicolumn{18}{|l|}{$\begin{array}{l}\text { 4.- } \\
\text { IMPERMEABILIZACIÓN } \\
\text { Y AISLAMIENTO }\end{array}$} \\
\hline \multicolumn{18}{|l|}{$\begin{array}{l}\text { 5.- REVESTIMIENTOS } \\
\text { CONTINUOS } \\
\end{array}$} \\
\hline \multicolumn{18}{|l|}{$\begin{array}{l}\text { 6.- RESTAUUACIÓN } \\
\text { SOLERIA }\end{array}$} \\
\hline \multicolumn{18}{|l|}{$\begin{array}{l}\text { 7.-CAARINTERIA DE } \\
\text { MADEA, } \\
\text { ARTESONADOS }\end{array}$} \\
\hline $\begin{array}{l}\text { 8.- CARPINTERÍA } \\
\text { METÁLICA }\end{array}$ & & & & & & & & & & & & & & & & & \\
\hline 9.- CERRAJERÍ́A & & & & & & & & & & & & & & & & & \\
\hline $\begin{array}{l}\text { 10.- INSTALACIÓN } \\
\text { FONTANERIAA }\end{array}$ & & & & & & & & & & & & & & & & & \\
\hline 11.- SANEAMIENTO & & & & & & & & & & & & & & & & & \\
\hline $\begin{array}{l}\text { 12.- ELECTRICIDAD, } \\
\text { ALTA TENSIÓN }\end{array}$ & & & & & & & & & & & & & & & & & \\
\hline $\begin{array}{l}\text { 13.- ELECTRICIDAD, } \\
\text { BAJA TENSIÓN }\end{array}$ & & & & & & & & & & & & & & & & & \\
\hline $\begin{array}{l}\text { 14.- ELECTRICIDAD, } \\
\text { EQUIPOS }\end{array}$ & & & & & & & & & & & & & & & & & \\
\hline $\begin{array}{l}\text { 15.- CLIMATIZACIÓN, } \\
\text { DISTRIBUCIOON }\end{array}$ & & & & & & & & & & & & & & & & & \\
\hline $\begin{array}{l}\text { 16.- CLIMATIZACIÓN, } \\
\text { EQUIPOS }\end{array}$ & & & & & & & & & & & & & & & & & \\
\hline $\begin{array}{l}\text { 17.- PROTECCIÓN } \\
\text { CONTRA INCENDIOS }\end{array}$ & & & & & & & & & & & & & & & & & \\
\hline 18.- SEGURIDAD & & & & & & & & & & & & & & & & & \\
\hline $\begin{array}{l}\text { 19.- CONTROL DE } \\
\text { INSTALACIONES }\end{array}$ & & & & & & & & & & & & & & & & & \\
\hline 20.- VIDRIOS & & & & & & & & & & & & & & & & & \\
\hline 21.- PINTURAS & & & & & & & & & & & & & & & & & \\
\hline $\begin{array}{l}\text { 22.- APARATOS } \\
\text { SANITARIOS Y } \\
\text { GRIFERIAS }\end{array}$ & & & & & & & & & & & & & & & & & \\
\hline $\begin{array}{l}\text { 23.- APARATO } \\
\text { ELEVADOR }\end{array}$ & & & & & & & & & & & & & & & & & \\
\hline 24.- LIMPIEZA OBRA & & & & & & & & & & & & & & & & & \\
\hline 25.- EQUIPAMIENTOS & & & & & & & & & & & & & & & & & \\
\hline $\begin{array}{l}\text { 26.-SOPORTES } \\
\text { EXPOSITIVOS }\end{array}$ & & & & & & & & & & & & & & & & & \\
\hline $\begin{array}{l}\text { 27.- REUBICACIÓN } \\
\text { PIEZAS }\end{array}$ & & & & & & & & & & & & & & & & & \\
\hline 28.- SEÑALETICA & & & & & & & & & & & & & & & & & \\
\hline $\begin{array}{l}\text { 29.- LIMPIEZA } \\
\text { GENERAL }\end{array}$ & & & & & & & & & & & & & & & & & \\
\hline $\begin{array}{l}\text { 30.- SEGURIDAD Y } \\
\text { SALUD }\end{array}$ & & & & & & & & - & $=$ & & & & & & & & \\
\hline $\begin{array}{l}\text { 31.- CAMPAÑA DE } \\
\text { DIFUSIÓN }\end{array}$ & & & & & & & & & & & & & & & & & \\
\hline
\end{tabular}


XIV. PREVISIONES DE CRECIMIENTO, VIABILIDAD Y ESTABILIDAD. 


\section{PREVISIONES DE CRECIMIENTO, VARIABILIDAD Y VERSATILIDAD.}

El objetivo de nuestro Proyecto, musealizar y poner en valor el Monasterio de San Jerónimo de Granada, es explicar el edificio en sí mismo, sus espacios, su historia, etcétera. Por lo que las previsiones de variabilidad y versatilidad son escasas.

En cambio, consideramos que el Monasterio Museo de San Jerónimo debe plantearse un crecimiento, tanto de la propia institución como del espacio.

Deberá crecer como institución adoptando los siguientes criterios:

- Incrementar el número de visitantes.

- Mejorar la calidad de la visita, incorporando nuevas tecnologías que faciliten la comprensión del discurso expositivo.

- Impulsar la investigación, otorgando becas a investigadores y facilitando la publicación de sus conclusiones.

En cuanto al espacio, consideramos que la opción más válida es incorporar a la institución el edificio de la Escuela de Latín y Música, como ya hemos planteado en otros apartados del Proyecto. En este edificio podría construirse un auditorio, una sala de exposiciones temporales, un restaurante- cafetería, etcétera. Las ventajas serían muchas, entre otras:

- La ciudad ganaría un nuevo espacio en el que se desarrollarían todo tipo de actividades culturales.

- La rehabilitación de este edificio supondría un impulso económico para la zona. 
XV. APÉNDICE. 


\section{APÉNDICE.}

Hemos incluido en este apéndice del Proyecto una serie de documentos que nos han parecido interesantes para la comprensión del mismo.

- Cartografía histórica. Hemos seleccionado algunos planos en los que se puede ver el Monasterio de San Jerónimo:

- Plataforma de Ambrosio de Vico de 1613, copia de Felipe Prieto en 1795.

- Plano de Granada de Francisco Dalmau, 1796.

- Plano de Granada de Francisco Contreras, 1853.

- Una serie de Vistas de Granada, en las que podemos apreciar la imagen del Monasterio de San Jerónimo según diversos artistas:

- Vista de Granada, 1563 y 1564 Joris Hoefnagle. Museo Casa de los Tiros, Granada.

- Detalle acuarela del viaje de Cosme de Medicis, 1669

- Detalle de Vista de Granada, Isidoro Marín. Óleo sobre lienzo, (h. 1906). Museo Casa de los Tiros, Granada.

- Detalle de Profil de la Ville de Granade. Grabado siglo XVIII, Francia. Museo Casa de los Tiros, Granada.

- Detalle de Vista de Granada desde el Generalife, A. Guesdon. Imp. de la Rue, París. Litografía, (h.1860). Museo Casa de los Tiros, Granada.

- Detalle Vista de Granada desde la plaza de las Toros, A. Guesdon. Imp. de la Rue, París. Litografía, (h.1860). Museo Casa de los Tiros, Granada.

- Algunos de los decretos y leyes que se han promulgado sobre el Monasterio de San Jerónimo de Granada:

- Decreto 2400/1962, de 20 de septiembre, por el que se cede en usufructo el monasterio de San Jerónimo de Granada a la Orden Jerónima.

- Decreto 501/1965, de 4 de marzo por el que se amplia la cesión en usufructo a la Orden de San Jerónimo del Monasterio de dicho nombre en Granada.

- Ley 65/1967, de 22 de julio sobre la ampliación de cesión en usufructo a la Orden de San Jerónimo. 


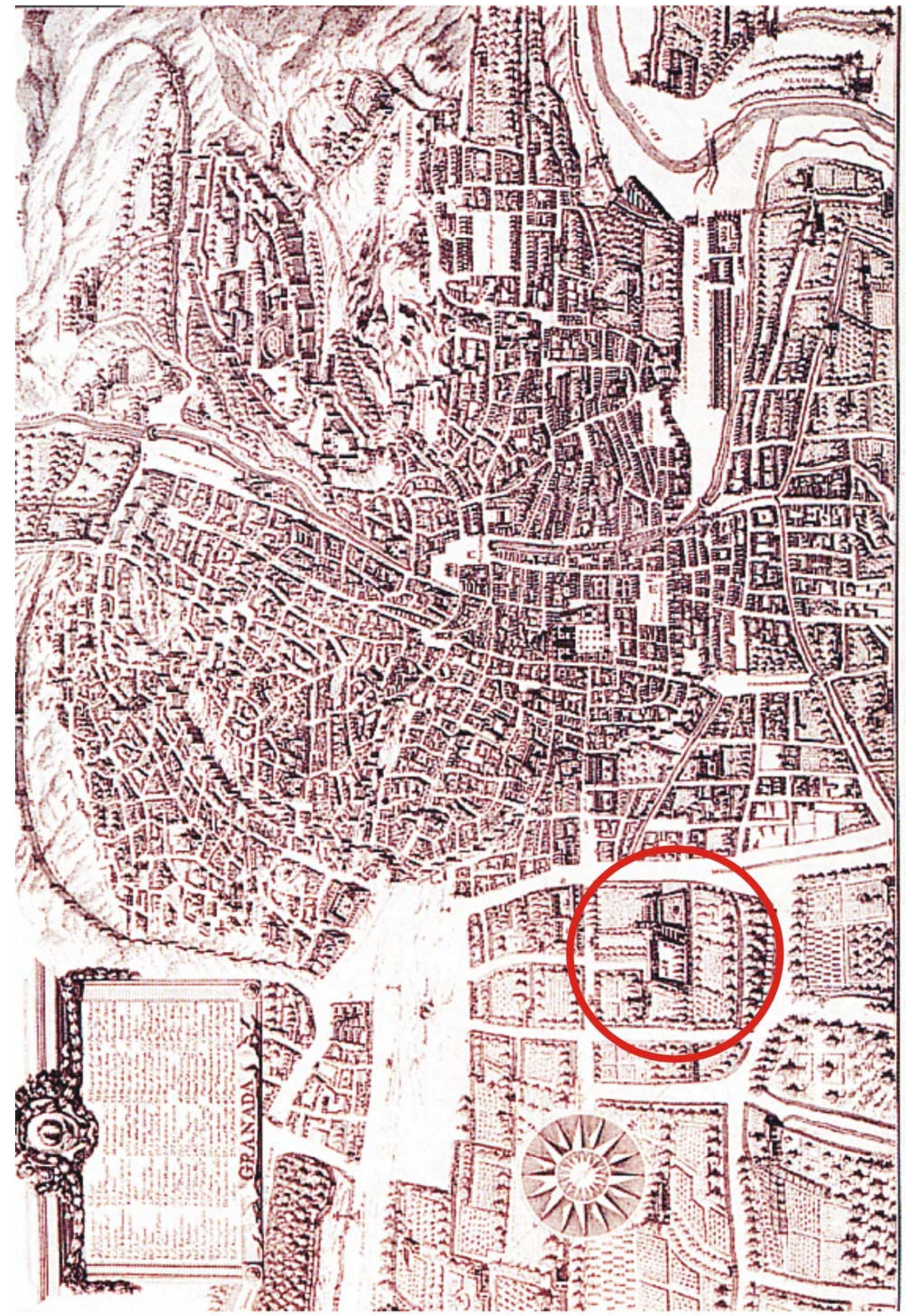

AMBROSIO DE VICO, 1613.

Red. FELIPE PRIETO, 1795 


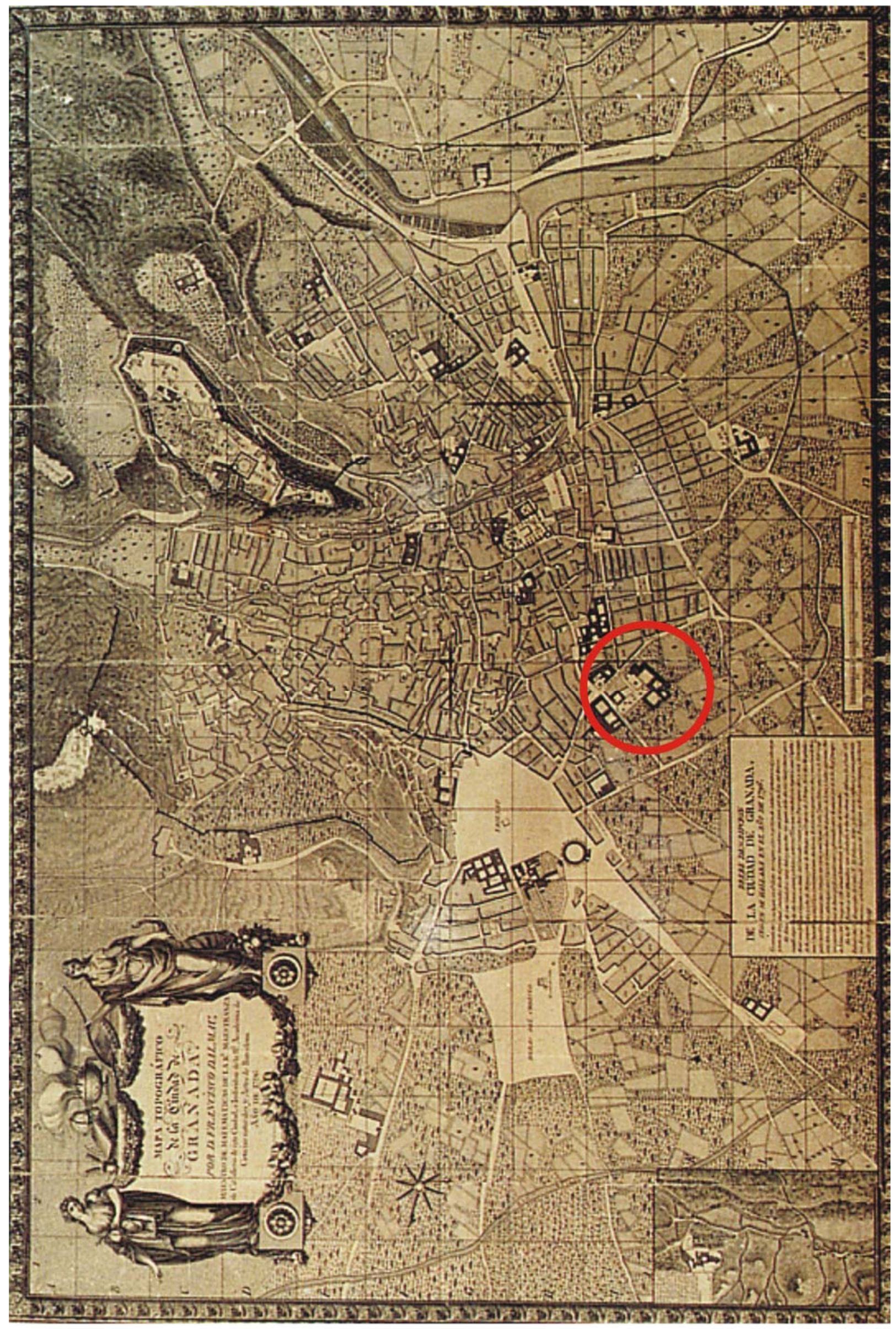

FRANCISCO DALMAU, 1796 


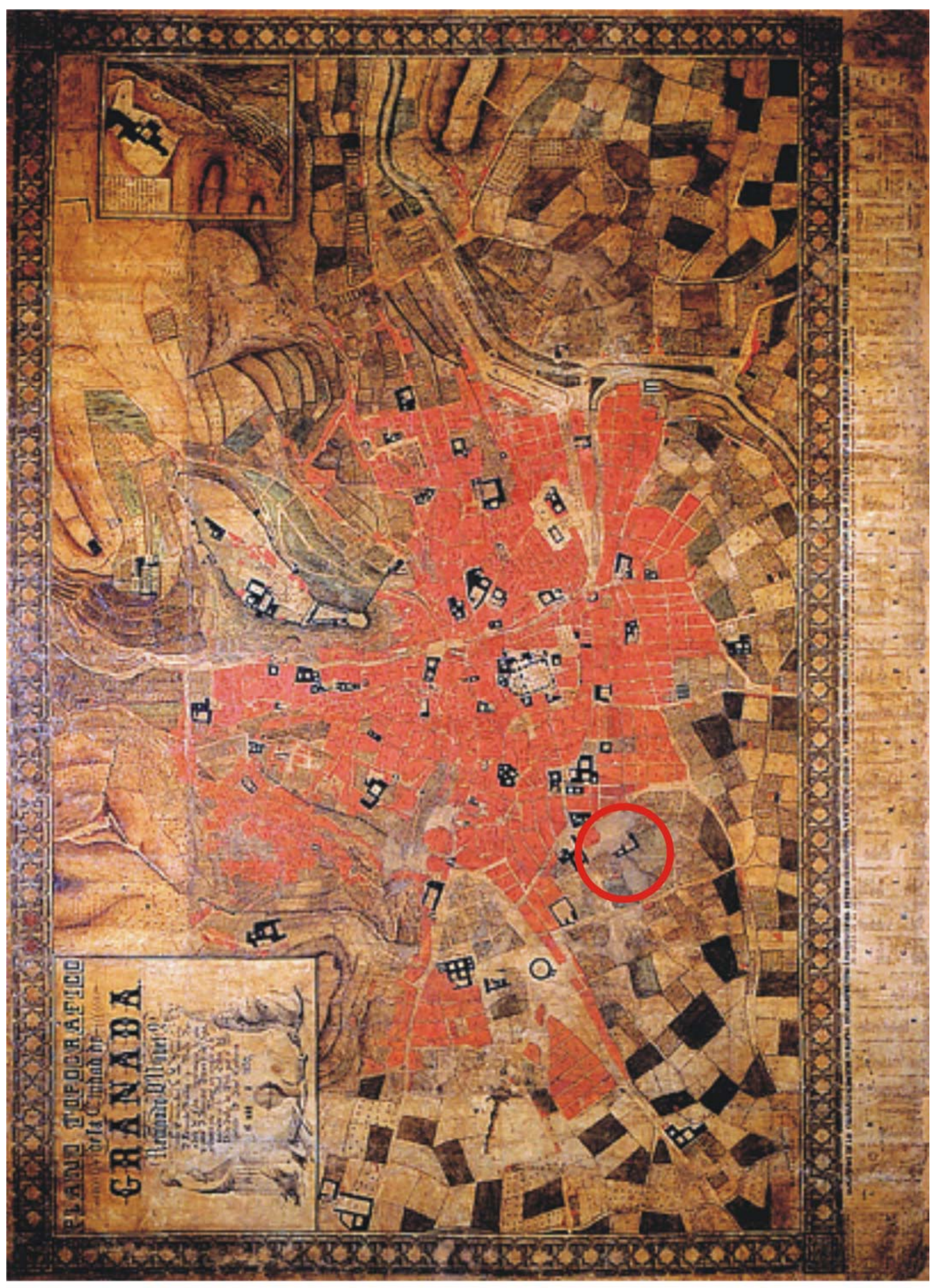

MONASTERIO DE SAN JERONIMO, CONTRERAS, 1853 


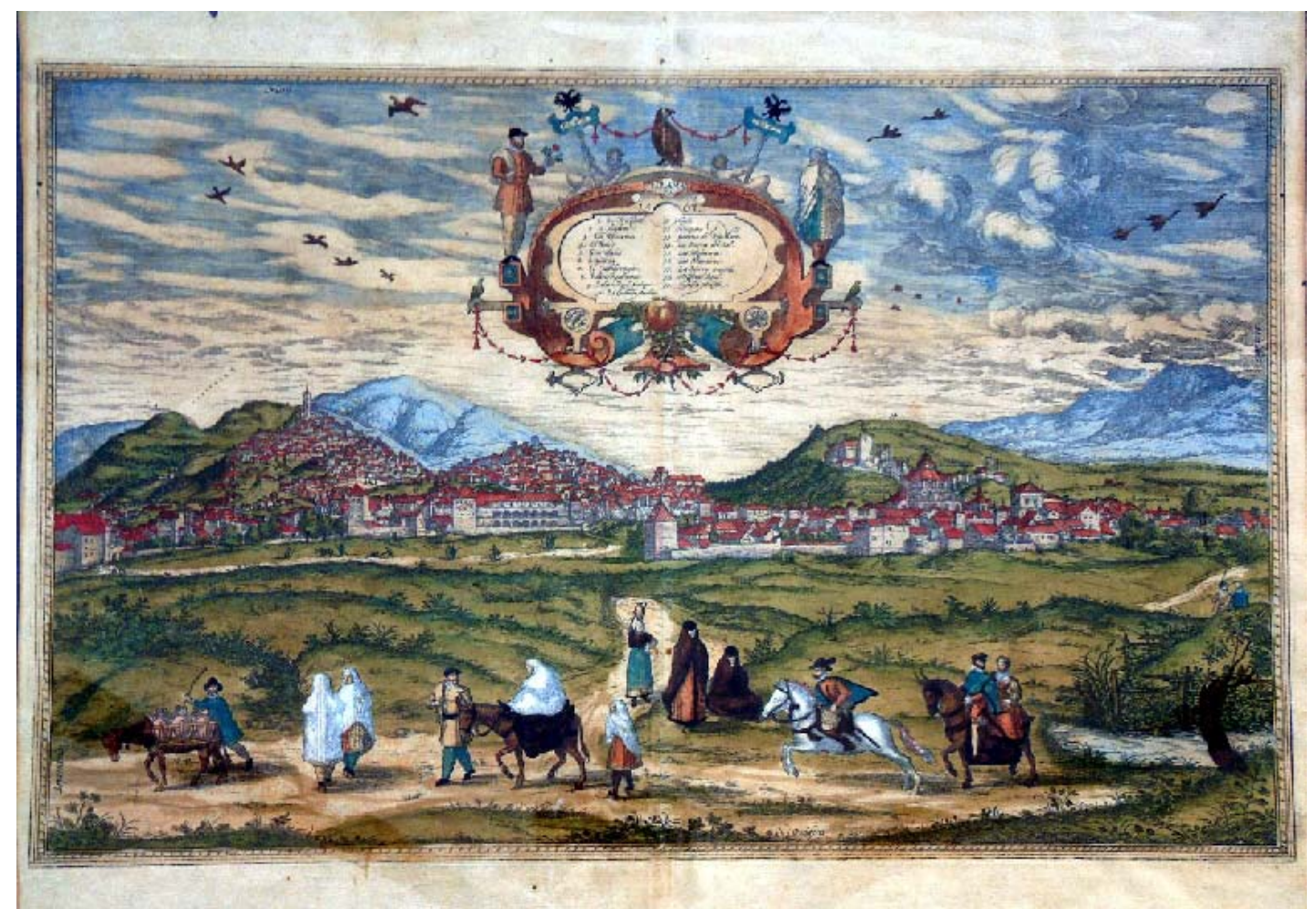

Vista de Granada desde la Vega en el siglo XVI. J. Hoefnagle (1563). Museo Casa de Los Tiros.

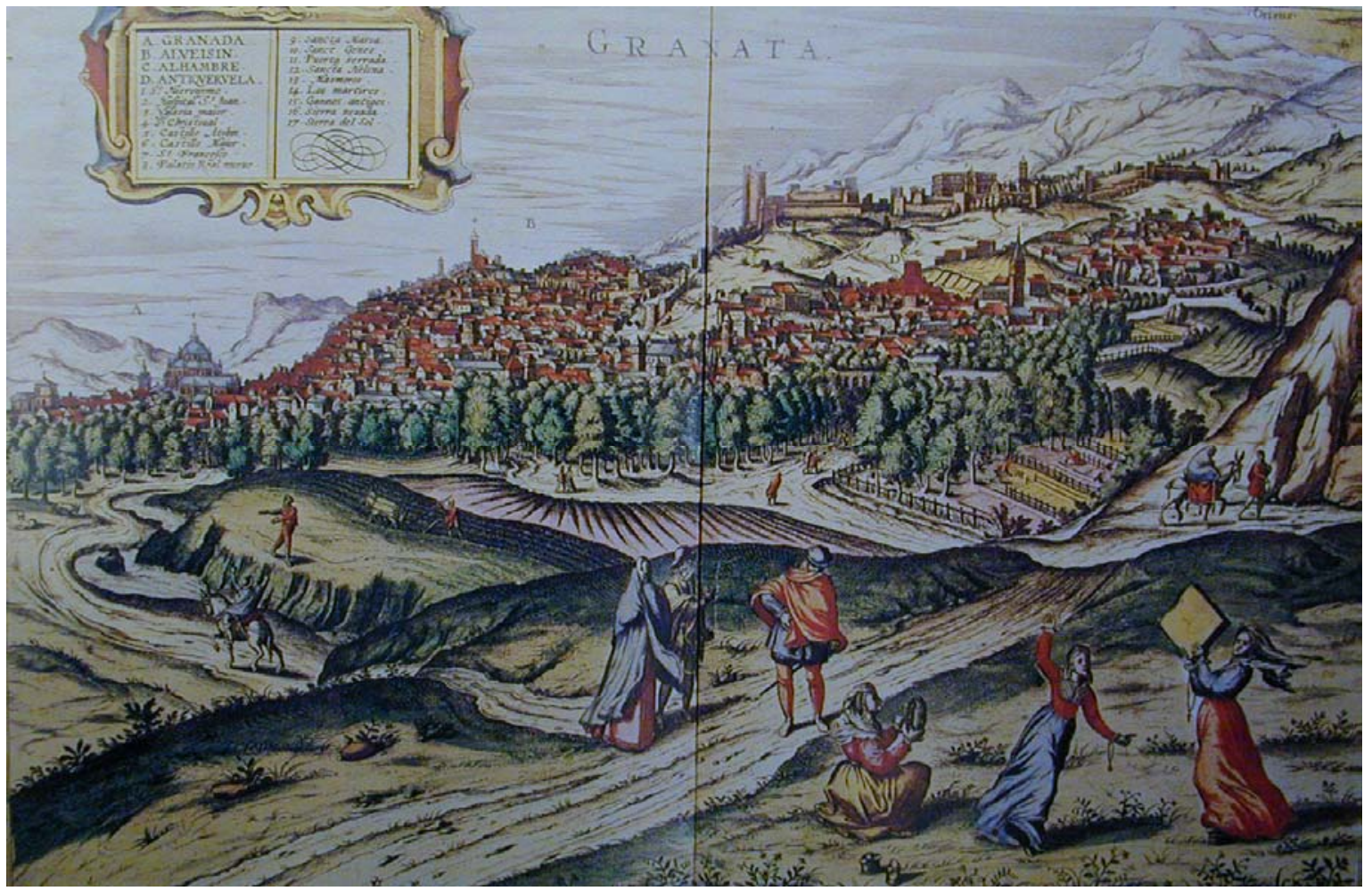

Vista de Granada en el siglo XVI. J. Hoefnagle (1564). Museo Casa de Los Tiros. 


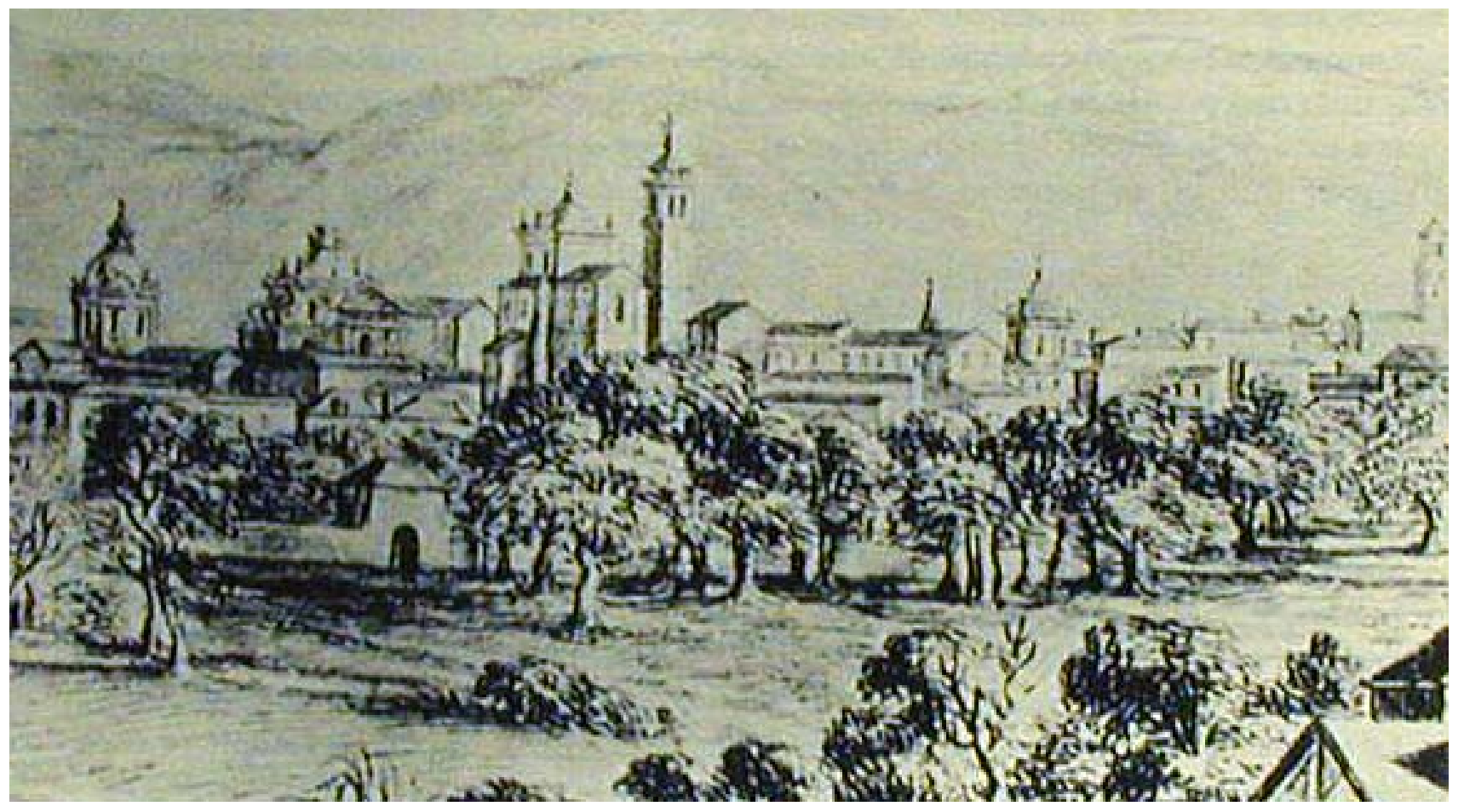

Detalle acuarela del viaje de Cosme de Médicis en 1669.

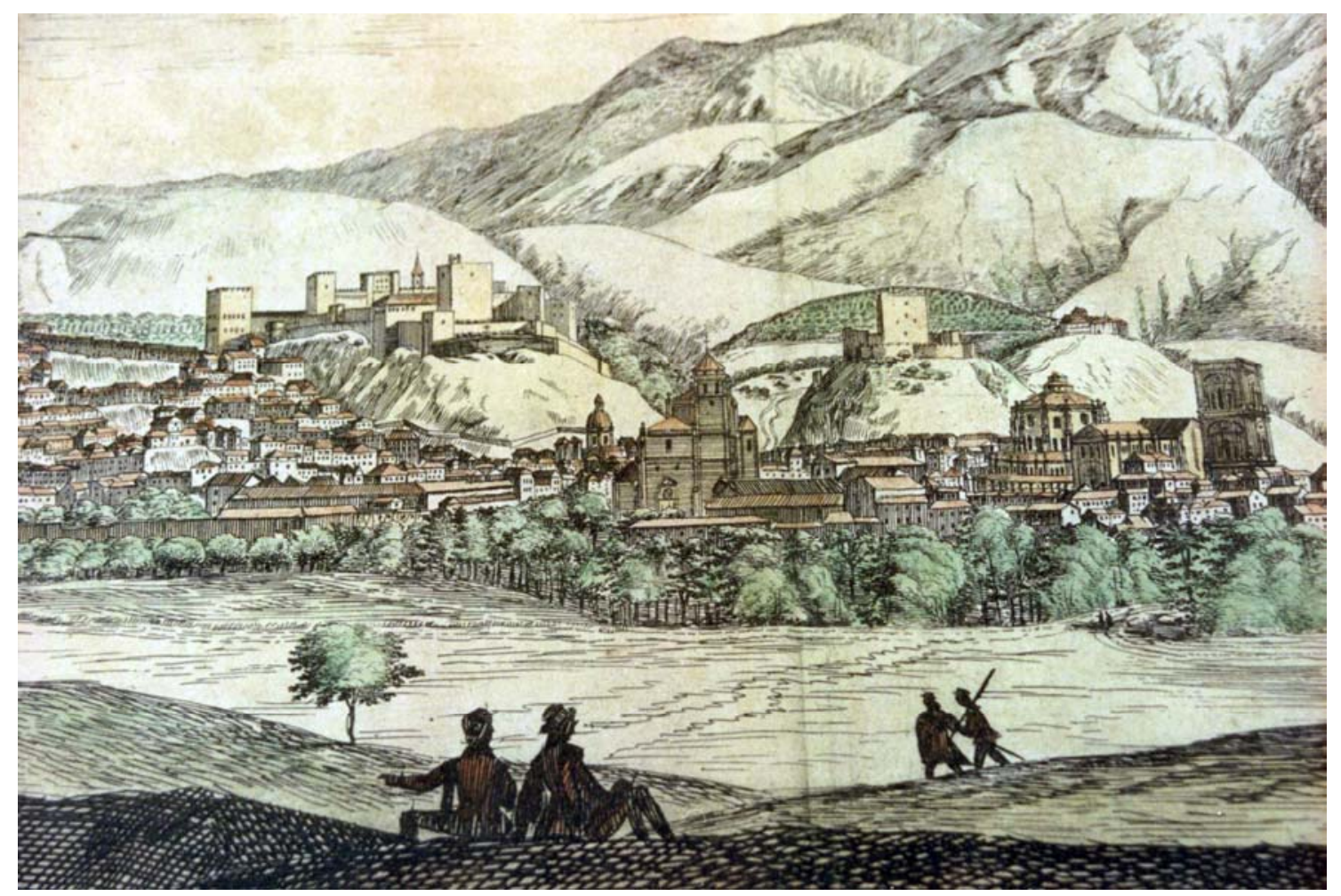

Detalle de Ville de Granade, grabado francés del siglo XVII. Museo Casa de los Tiros. 


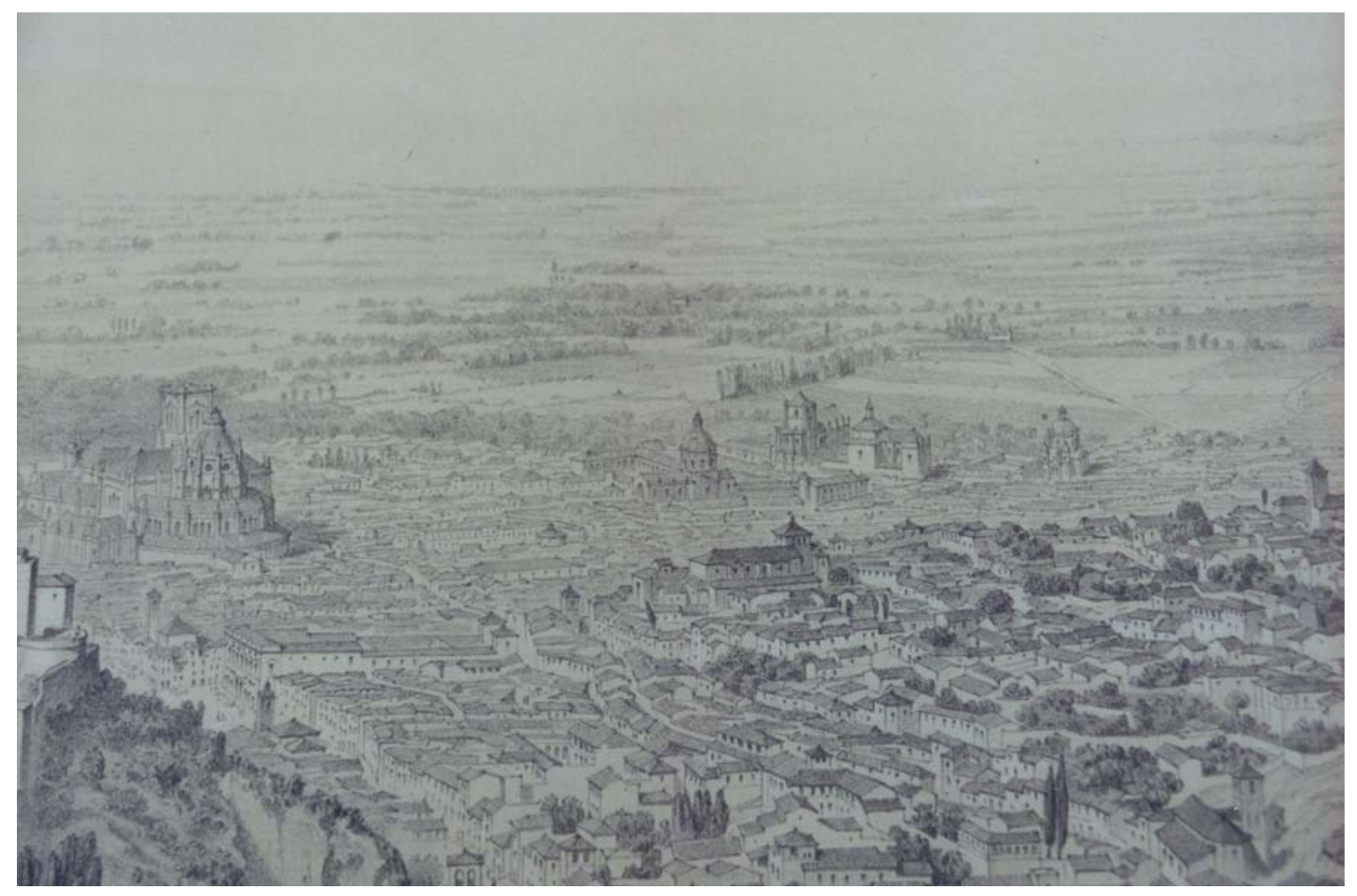

Vista de Granada desde el Generalife (h. 1860) A. Guesdon. Museo Casa de los Tiros.

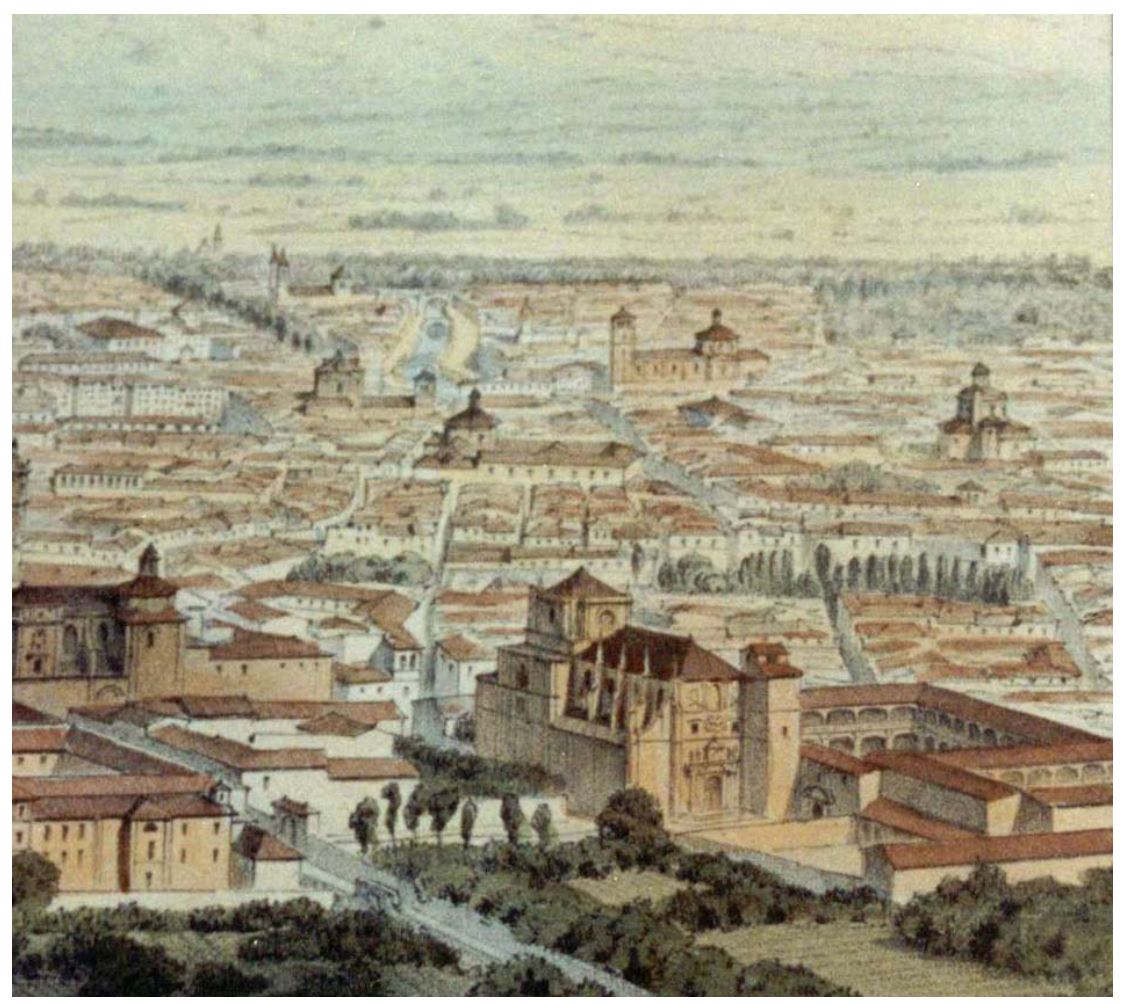

Detalle de Vista de Granada desde la Plaza de Tiros. A. Guesdon (h. 1906). Museo Casa de los Tiros. 


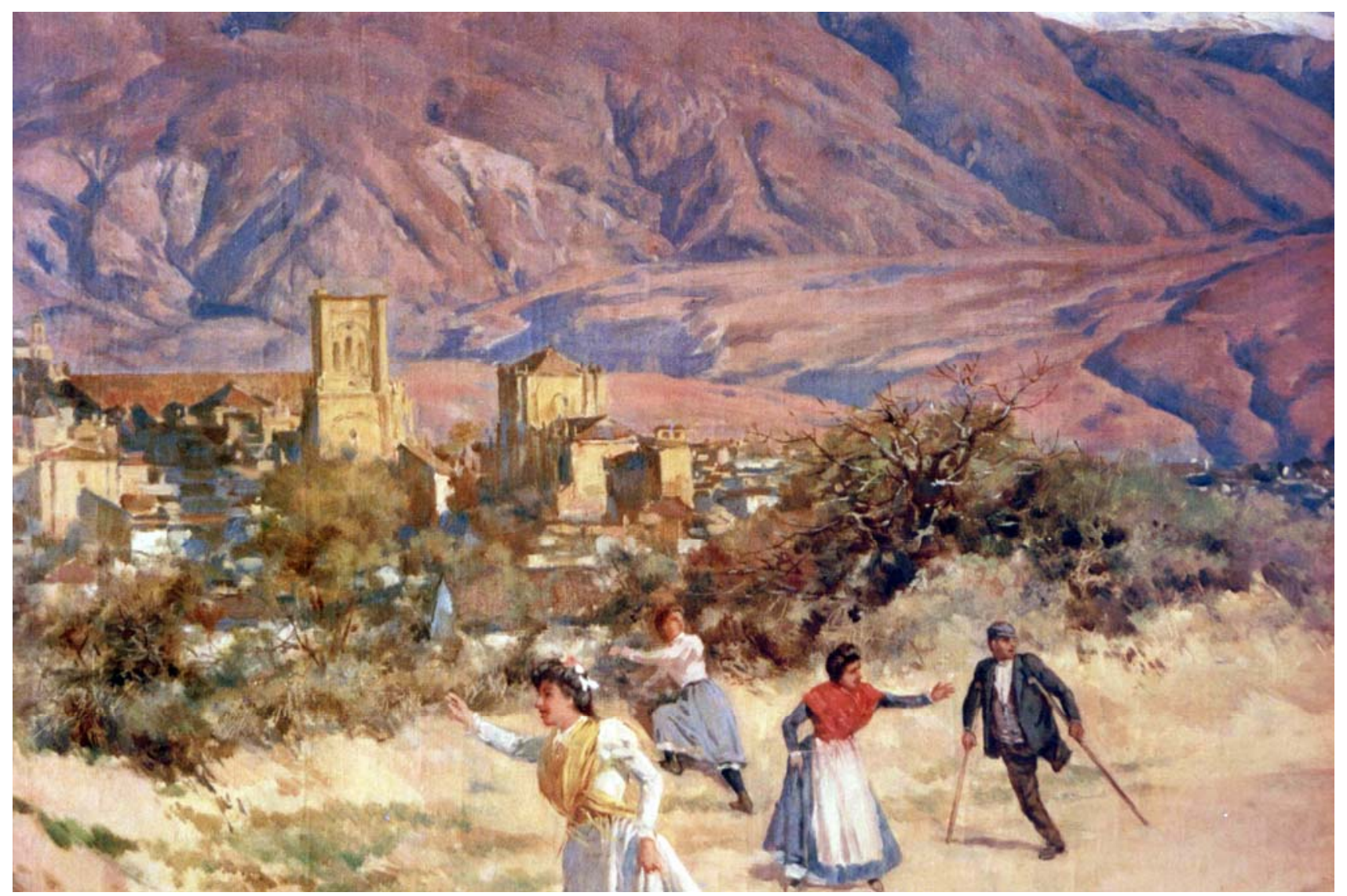

Detalle de Vista de Granada, Isidoro Marín (1906). , Museo Casa de los Tiros. 
Vengo en concederle la Gran Cruz del Mérito Naval, con ustintivo blanco.

Asi to dispongo por el presente Decreto, dadu en Madrid uso de octuore de mil novecientos sesenta y dos.

FRANCISCO FRANCO

Atinistro de Marina.

PEDRO NIETO ANTUNEZ

$$
\text { - }
$$

DECRETO 2399/1962, de 1 de octubre, por el que se concede la Gran Cruz del Mérito Naval, con distintivo blanco, a don Jose Salgado Torres.

consideracion a las circunstancias que concurren en Salgado Torres,

en concederle la Gran Cruz del Mérito Naval, con Veriso en conced

datimivo blanco.

A.t lo dispongo por el presente Decreto, dado en Madrid a uno de octubre de mil novecientos sesenta y dos.

\section{FRANCISCO FRANCO}

E1 Ministro de Marina.

PEDRO NIETO ANTUNEZ

ORDEN de 1 de octubre de 1962 por la que se concede la Cruz del Mérito Natal, con distintivo blanco, de la clase que a cada uno se expresa, al personal que se menciona.

En atención a los meritos contraidos por el personal del Ejérdel Aire que a continuación se relaciona, vengo en conce.

ies la Cruz del Mérito Naval, con distintivo blanco. do ia e que para cada uno de cllos se expresa:

Comandante don Luis Arancibia Resines, de segunda

Capitán don Enrique Nieto Rodriguez, de primera.

ento don Victor Aguado Hermoso, de primera.

Sarkento don Florenclano Soria Vinuesa, de primera.

Miadrid, 1 de octubre de 1962.

NIETO

ORDEN de 1 de octubre de 1962 por la que se concede la Cruz del Merito Naval de tercera clase, con distintivo blanco, a don Manuel Padrón Quevedo.

fi atención a los méritos contraidos por don Manuel Padrón do, vengo en concederle la Cruz del Mérito Naval de terise; con distintivo blanco.

Madrid, 1 de octubre de 1962.

NIETO

ORDEN de 1 de octubre de 1962 por la que se concede la Cruz del Merito Naval de tercera clase, con distintivo blanco, a don Jose L. Benjumea Medina.

En atención a los méritos contraidos por don José L. Benmea Medi: a, vengo en concederle la Cruz del Mérito Naval de reera clase, con distintivo blanco.

Madrid, 1 de octubre de 1962.

NIETO

ORDEN de 1 de octubre de 1962 por la que se concede la Cruz del Merito Naval de tercera clase, con distintivo blanco, a don Andres Guerreiro Prieto.

atención a las méritos contraldos por don Andrés que. erleto, vengo en concderle la Cruz del Mérito Naval de lase, con distintivo blanco.

aitrid. 1 de octubre de 1962.

NIETO

\section{MINISTERIO DE HACIENDA}

DECRETO 2400/1962, de 20 de septtembre, por el que se cede en usufructo el monasterio de San Jerónimo de Granada a la Orden Jeronima.

La Importancia artistica del monasterio de San Jerónimo de Granada corre pareja con su siznificación histórica.

Fundación de los Reyes Católlcos en mil cuatrocientos noventa y dos, en Santa Fe, trasladada luezo a Granada, donde se comenzó el edificio en mil cuatrocientos noventa y seis, es obra ésta en la que Diego Siloé dejó orizinales muestras de su genio artistico.

La Orden de San Jerónimo tuvo a su car so esta fundación desde mill quinlentos diecinueve hasta ia implantación de la llamadas Leyes Desamortizadoras, y es esa misma orden la que en la actualidad ha atendido a la restauración del edifteto. diante encomiable labor de la reverenta Madre general Sor Cristina de la Cruz Arteaza.

Por todo ello y para que la conservacion de este monumento. declarado histórico-artistico en veinticuatro de mayo de mil ochocientos setenta y siete, se mantenza con el decoro y diznidad debidos, parece obligado encomendar tal cuidado a una Orden Religiosa, y ninguna de las actualmente existentes en España con mejor titulo, por cuanto queda expuesto, que la mencionada de San Jeronimo

En su vircud, a propuesta c Ministro de Haclenda y previa deliberaclón del Consejo de M..uistros en su reunión del dia ocho de Junlo de mil novecientos sesenta y dos,

$$
\text { DISPONGO : }
$$

Articulo primero,-Se cede en usufructo por un plazo de treinta aflos a la citada Orden de San Jerónimo cl Monasterio de San Jerónimo, de Granada, la Izlesia y el claustro del an tiguo convento, a fin de que se restablezea en ellos la vida monástica conforme a sus propias leycs.

Articulo segundo.-Si el Estado no declarase caducada esta concesión dentro del ultimo ańo de! plazo citado, se entenderá prorrozada la misma por otros treinta años, $\mathrm{y}$ ast sucesivamente.

Articulo tercero.- La izlesia del monasterio podrá ser visi. tada por el público según el horario que deteraiue el Pacire Prior, el cual deberá ser comunicado a la Dirección General de Bellas Artes.

Artículo cuarto - La Orden de San Jerónimo no podrá realizar obra alguna en los inmuebles de San Jerónimo de Granada sin autorización del Ministerio de Educación Nacional. y slem. pre bajo la dirección o inspección de los Servicios Ticnicos correspondientes de la Dirección General de Bellas Artes.

Artículo quinto. - Se formalizará la entrega de los edificios cedidos a la referida Orden mediante acta notarial suscrita en nombre del Estado por el ilustrisimo señor Delegado de $\mathrm{Ha}$ cienda en Granada.

Al acta se unirá un plano en el que con el visto bueno del Rector de la Universidad de Granada se delimitarí el área que se cede en uso a la Comunidad Jerónima.

Articulo sexto.- En el mismo acto de la entrega se formallzarán tamblén los oportunos inventarios de los muebles y objetos que figuren en los edificlos que se ceden. cuyos inventa. rios serán suscritos por las :`presentaciones de la Orden Jerónima y del Estado conjuntamente.

Artículo séptimo.-Por el Ministerio de Hacienda se dicta. rán cuantas disposiclones se consideren nec:sarias para el cumplimiento de lo que en este Decrcto se establece.

Asi lo disponzo por el presente Decreto, dade en Madrid a veinte de septiembre de mil novecientos sesenta $y$ dos.

El Ministro de Haclenda.

FRANCISCO FRANCO

\section{MIARIANO NAVARRO RUBIO}

ORDEN de 3 de septiembre de 1962 por la que se aprueba cambio de domicilio y modificacion del articulo tercero de sus Estatutos sociales a la Entidad aLa Prer'sora Catalana, $S$. A.m.

Ilmo, Sr.: Visto el escrito de aLa Previsora Cata'ana, S. A.». en el que da cuenta del cambio de domicilio social de la Via Layetana, 52. al numero 77 . cuarto tercera, de la misma calle, adjuntanjo al mismo tiemro lestimonio notarial de ta modifcación del artículo 3 . de sus Estatutos sociales, 
Vistas la Ley de dieclocho de funio de mil ochocientos seten. ta, rezulaciora de la gracla de indulto. y el Decreto de veintidos de abril de mul novecientos trelnta y ocho.

Oido el Ministerio Fiscal y de acuerdo con el parecer del TT bunal sentenciador, a propuesta del Ministro de Justicin y previa dellberación del Consejo de Ministrus en su reunlón del día dieVengo en findultor mil noveclentos sesenta y cinco.

vengo en Indultar a José Luis Presa Diez de la mitad de la pena privativa de libertad que le queda por cumplir y que le fué impuesta en la expresada sentencla.

asi lo dispongo por el presente Decreto. dado en Madrid eintro de marzo de mil novecientos sesenta y cinco

\section{EI MINAStro de Justicia,
ANTONIO ITURMENDI BARALEB}

FRANCISCO FRANCO

\section{MINISTERIO DEL E.JERCITO}

DECRETO 499/1965, de 27 de febrero por ol que st concede la Gran Cruz de la Real y Militar Orden de San Hermeneglido al General de Brigada de In/ant. teria don Joaquin Bosch de la Barrera. En cons!deracion a lo sollcitado por el General de Brigada con lo propuesto por la Asamblea de la Real y .Militar Orde1 de San Hermeneglido

Vengo en concederle la Gran Cruz de la referida Orden, con Ia antiguedad del dia treinta do octubre de mil novecientcs se senta y cuatro, fecha en que cumplió las condiciones regla-

veintislete de febrero de el presente Decreto, dado en Madrld н

\section{FRANCISCO FRANCO}

CI Ministro del Ejercito

DECRETO 5Q0/1965, de 27 de febrero, por el que se concede la Gran Cruz de la Real y Multar Orden de San Hermenegtldo al General de Brigada de In. tanteria don Luis Gomez Hortigillelo

En consideracion a lo solicitado por ei Cieneral de Brizada do Infanteria don Luis Gomez Hortiguela y de conformidad con lo propuesto por la Asamblea do la Real $v$ Militar Orden de San Vengo en

la antiguedad del dia quince de Cruz de la referida Orden, cun centa y cuatro, fecha en que do octubre de mil novecientas se genta

ial lo dispongo por el presente Decreto dado en Madrict veintialete de febrero de mili novecientos besenta y clinco

L1 Ministro del EyArcito,
MLIO MENENDEZ TOLOB

FRANCISCO FRANCO)

ORDEN de 9 de marro de 1965 por la qui se detros cuadrados de terrenos sitos en el pe $4.350 \mathrm{me}$ tros cuadrados de terrenos sitos en el poligon

A las efectos pertinentes, so hace publico que el consejo de Ministros celobrado el día o de marzo de 1966 ncordo declarut de utililad pública la adquisiclón por el Extndo y in urgente rrenos altos en el polígono II del termino nuundrados de te(Valencia), segun se detalla en la sigulento relnclon, n lo iline de npertura de poz.os para captación de aguns para n ce Instruccion de Reclutas numero ?

\begin{tabular}{|c|c|c|}
\hline Parceln & Propletario & $\begin{array}{c}\text { Minu-rficin } \\
\text { in }\end{array}$ \\
\hline $\begin{array}{l}2.38 \\
2.55 \\
32.5\end{array}$ & 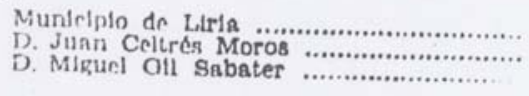 & $\begin{array}{r}2.210 \\
240 \\
1.9010\end{array}$ \\
\hline
\end{tabular}

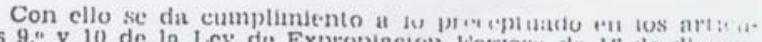
ore de 1954 , sut Madrid. A de marzo de 1965.

MENENDF: $/$

\section{MINISTERIO DE HACIENDA}

DECRETO 501.1965. de 4 de marzo, por el qur ... amplia la cesión en usufructo a la Orden de Sa" eronimo del Monasterio de dicho nombre en Granu. da, parte del cual fué cedido por Decreto $2400 / 19$ ti:. de 20 de septiembre, y, se crea un Patronato encar. gado de la conservación de dicho Monumento.

Por Decreto del Ministerio cle Hacienda de veinte de septien. bre de mil novecientos sesenta y dos se redió en usufructo p.st Ai objeto de y el claustro del antiguo convento.

orden a la finalidad para la que fué reolizada se pretendida en

a) Ampllarla parı comprruder en ella el aia del menclorio ediflcio hasta el límite acordado para las terrenos que la Uniersidad ha de seguir omipando;

b) Establecer las servidumbres que se derivan cle esta cesion: c) Crear el Patronato que ha de eneargarse de la conservi.

En su consecuencia, a propuesta de 10.5 Ministetios de H.. cienda y Educación Nacional, y prevla deliberación del Conse de Ministros en su reunión del día diecinueve de febrero de mil novecirntos sesenta y cinco.

$$
\text { DISPONGO }
$$

Articulo primero,- La cesión del Munusterio de San Jeronm de Cranada hecha a la Orden. Jcrónima por Decreto dos mi

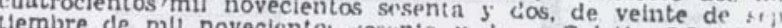
Estadon de mil novecientos sesenta y dus iaBoletin OAcial ... $y$ condiciones esta octubre, se amplia, "n las mismos térmliu. del edificio o segunclocidos en dicha dispnsición, al ala deren.

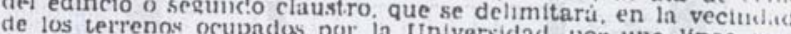

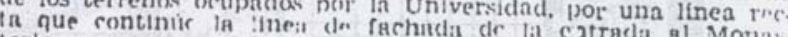
terio.

Articulu sequndo.-A nada pase contlikuon al Monasterio ae chari acceso por el compas del mismo, renlizandose. a ta! efecto, las obras necesarias parn que contlintie esta servidumbre del mindn que inenos grnvoso ir. Hite para c! mredic sirviente.

Articulo tercero - La visita a que sit refiere el articulo cero del Decrelo de veinte de septlembro de wnta y dos se extenderat a la Sacristla y planta baja del claustro principal a losacio a la Iglesia

Articulo cuarto.-Para velne por lit adeciuada (c) Monumento se creará un Patronnto

Articulo quinto. Se nutoriza a las Mimusterlos de Educación Nacional para q ie en la esfera de sus Haclent.. I competenclas puedan dictar las ordenes qui de sus respectives, rias para el cumplimiento de lo extablecido en este Decrivio

Asi It dispongo por at presente Decroto, dado en Madrut ruatro de marzo de mil nuvecientos sesenta y cincu.

EI Minintro de Hacienda
MARIANO NAVARRO R(BI()

PIRANCISCO FRANCD

RESOLUCION del Tribunul de Contrabana. de Alyectras por la gur er hace priblico ol acherdo que
se ctea

kil llustrisimo sefor Presiclente on exte Tribunal, en virtud de las facultades que le confleren ins urtimulos 55 y 78 de vikente Ley de Contrabando, ha dictaclo on el expediente nú-

1." Declnrar cometida una intraceión de cuntrabands de Iima cuantis. comprendidn en el coses l del articulo is de. In Ley citnda

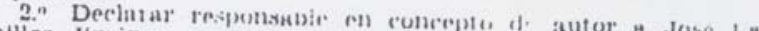
millios Jimeney

3." linponer In sikulente multa: 200a mesetas,

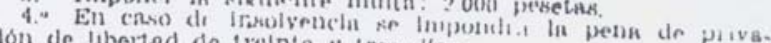

ton de libertad de tremtanta $y$ tres dises.

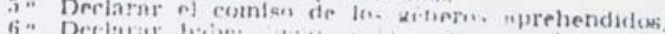

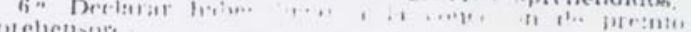




\section{Otras disposiciones}

\section{JEFATURA DEL ESTADO}

LEY $64 / 1967$, de 22 de julio, por la que se cede gratuitamente a la Orden de la Merced la nuda propiedad del Monasterio de Santa Maria, de El Puig (Valencia).

21 Rey Jaime I de Aragón, en conmemoracion de la batalla de I1 Puig. decisiva para la conquista de Valencia, dispuso en el mil dosclentos treinta y ocho la erección de un Santuario y nasterio a escasa distancia de aquella cludad, en el mismo yodonde su consejero real. San Pedro Nolasco, habia descubierto por vistón sobrenatural, un bajorrelleve poli habia descubierto bizantino representando a la Virgen de los Angeles.

Encomendo el cuidado del mismo a la Orden de la Merced, fundada poco antes por San Pedro Nolasco, y en manos de esta Orden permaneció el monumento durante seis siglos hasta is incautacion por el Estado en virtud de las leyes desamortizadoras. La Orden de la Merced recuperó la posesión del Monasterio mediante una Orden del Ministerio de Hacienda de diecisiete de marzo de mil novecientos cuarenta y ocho que se lo cedió en usufructo. Desde dicha fecha la Orden mercedaria ha cedio do a costa de sacrificios extraordinarios, la reconstrucción de alguno de los elementos esenciales del monumento, serlamente dañados a consecuencia del anterior abandono, $\mathrm{y}$ desea llevar a feliz término la total restauración del Santuario, tan enraisado en los sentimientos de la región valenciana.

Atendiendo además a la petición dirigida por escrito al $\mathrm{Mi}$. nisterio de Hacienda por nutrida representación de las fuerzas vivas de la región, el Goblerno remitió a las Cortes el oportuno proyecto de Ley.

En su virtud, y de conformidad con la Ley aprobada por las Corteg Españolas, vengo en sancionar:

Articulo primero.-Se cede gratuitamente a la Orden de ta Merced la nuda propledad del Monasterio de Santa Maria de los Angeles, de EI Puig (Valencia), reservada por el Estado 2 su favor en virtud de Orden dictada por el Ministerio de Hacienda de diecislete de marzo de mil novecientos nisterio de ocho: consolidándose de este modo el pleno cominio blenes en favor de la Orden de la Merced.

Artículo segundo.-La Orden de la Merced continuara dedicando por tiempo indefinido los bienes citados a fines religiosos $\checkmark$ de interés social. Lo aplicaciós de este bienes por el cesionorio, en cualquier tiempo, a fines distintos de los expresados producirá la reversión de los mismos en favo: del Estado.

Dada en el Palacio de El Pardo a veintidós de jullo de mil novecientos sesenta y siete.

FRANCISCO FRANCO

I1 Presidento do las Cortes.

ANTONIO TTURMENDI BAAALES

LEY 65/1967, de 22 de julio, sobre ampliación de cesión en usufructo a la Órden de San Jeró. rimo de un solar lindante con el Monasterio de di:ho nombre en Granada, el cual fué a su vez ce. dido por Decretos 2400/1962, de 20 de septiembre. y 501/1965, de 1 de marzo, credindose en este últi. mo un Patronato encargado de la conservación de dicho monumento.

For Decreto de veinte de septlembre de mil novecientos sesenis $z$ dos se cedió en vsufructo por un plazo de treinta afios la Orden de San Jerónimo, en Granada, la 1glesia y el claustro del antiguo convento, cesíon que fué ampliada por Decreto quinien. tos uno/mil noveclentos sesenta y cinco, de cuatro de mazo, por el ala derecha del edificlo o segundo claustro, quedando sin incluir en dichas ceslones un solar que formaba parte del inmue te, lo cual no fué posible efectuar en aquel entonces por hallarcocupado por servicios del Ministerlo del Ejército, aun cuando espiritu 7 is intención de la cesión aludida fué la de la tota ad del inmueble, si bien no pudo llevarse a cabo esto por el tuintivo expuesto.
Posteriormente en dieciséts de funio de mil novecientos seser: ta y seis, tal solar fué desocupado por los servicios del aludido Ministerio $y$ entregado al Patrimonio Privado del Estado. por Io que es llegado el momento de compietar la repetida cesión con el solar de que se ha hecho mérito

En su virtud, $y$ de conformidad con ia Ley aprobada por las Cortes Españolas, vengo en sancionar:

Articulo primero.-Se autoriza al Ministerio de Hacienda par ceder en usufructo a la Orden Jerónima el solar que a cont. nuación se describe con lo que quedan amplladas y completadas las cesiones aludidas en el preambulo de esta Ley, en iguales términos y condiciones que en aquellas se establecio:

solar denominado rTerrenos del Picadero del Antiguo Cuar tel de San Jerónumos. sito en Granada, con entrada por la calle Rector Lopez Argueta sin numero, con una superflicie de $m$ il custroclentos setenta y cuatro coma cincuenta metros cuadradas: que linda, al Norte, con finca llamada cLa Forestaln, afecta s. Ministerlo de Educación y Ciencia; Sur. casa llamada de ePare jaw; Este, calle Rector Lopez Argueta, y Oeste, placeta de la Iglesia de San Jeronimo. propledad del Estado y cedida por éste en usufructo a la Orden Jeronima.s

Articulo segundo. - Se autoriza asımismo a dicho Ministerto de Hacienda para que pueda dictar las órdenes que consider necesarlas para el cumplimiento de lo establecido en la presente Ley.

Dada en el Palacio de El Pardo a veintíós de julio de mi. novecientos sesenta $y$ siete.

E1 Presidence de las Cortes.

FRANCISCO FRANCO ANTONIO ITURMENDI BANALES

LEY 65/1967, de 22 de julio, autorizando al Mi. nisterio le Agricultura para enajenar el monte dei Estado "Cortijo de Santa Casilda, San Miguel " otros», sito en el término municipcl de Granada.

El monte del Estado rCortijo de Santa Casilda, San Miguel cuarenta y nueve coma mil trescientas dos hectáreas. y se halla situado en las proximidades de la ciudad de Granade. en zona que por sus caracteristicas es apropiada para el desarro. llo urbano de la ciudad, y of reciendo, por tanto, magnificia perspectivas para su utilizacion $y$ explotación urbanistica.

Esa especial situación da al referido monte un valor muy superior al derivado di su explotación forestal. Por ello re sulta de extraordinaria conveniencia la enajenación del aludido predio, con lo cual el Patrimonio Forestal del Estado po dria disponer de la masa dineraria que de ella se obtuviera para su adecuada inversión en la adquisicion de terrenos forestales en otras zonas apropiadas a sus fines. Tal conveniencia ha sido reconocida por el Consejo del indicado Patrimonio acto. En su virtud, y de conformidad con la Ley aprobada por las
Cortes Españolas. vengo en sancionar:

Artículo primero. - Se autoriza al Minis erio de Agricultura para que pueda disponer la enajenación del monte titulado en el Catálogo de montes de utilidad públlca e.Cortijo de Santa Casilda, San Miguel y otross, propiedad del Estado, sito en el término municipal de Granada, e integrado por las siguienes fincas:

Uno. Cortijo de Santa Casildas, de superficie de veintiuna coma sels mil doscientas cuarenta hectáreas, con los siguientes limites:

Norte: Camino viejo del Fargue.

Este: Resto de la finca de donde proceda, propledad de don antlago Gonzalez Sola.

Sur: "Cortljo del Alres y aCortijo d- San Miguels.

Inscrita en el Registro de ia Propiedar de Granada libro" setecientos veinte, follo clento veintinueve finca veintilin Ito clento sesenta $y$ uno. insctipción primera de once de dirterm. bre de mil novecientos cincuenti 
XVI. BIBLIOGRAFÍA. 


\section{BIBLIOGRAFÍA.}

1. Bibliografía sobre el contenido y la temática científica.

- ALCOLEA, Santiago.[1975] "Artes decorativas en la España cristiana" en Ars Hispaniae. Vol. XX, Madrid, 1975.

- ALDEA VAQUERO, Quintín, MARÍN MARTÍNEZ, Tomás, VIVES GATELL, José.[1973] Diccionario De La Historia Eclesiásticas De España, Madrid, 1973.

- ÁlVAREZ-GENDÍN Y BLANCO, [1956]. "El despojo del patrimonio eclesiástico por las leyes desamortizadoras" en Anales de la Real Academia de Ciencias Morales y Políticas, VIII, 1956.

- ÁNGUlO IÑIGUEZ, Diego. "Pintura del siglo XVIII" en Ars Hispaniae, vol.XV, Madrid, 1971.

- ARTEAgA Y FAlgUERA, Sor Cristina de la Cruz [1955]"¡Ay de mi Alhama! En Ideal, 22 de enero, Granada, 1955, pp.7 y 10.

- ARTEAgA Y FALGUERA, Sor Cristina de la Cruz.[1974] " La Orden de San Jerónimo, mecenas de todas las artes y su triple proyección en Sevilla" en Revista de la Academia de Bellas Artes de Santa Isabel de Hungría, Sevilla, 1974.

- AUBERSON MARRÓN, Luis Manuel.[1974] "El arte en la Orden de San Jerónimo" en A.R.A, $\mathrm{n}^{\mathrm{o}}$ 40, año X, 1974, pp. 64-74.

- BACHILleR SOLO, El. [1905] "Proyecto de estatuas: el Gran Capitán" en La Alhambra, 30 de octubre de 1905, pp. 434-447.

- BARBE COQUELIN DE LISLE, Genevieve. [1990]"La piedra y la arquitectura del renacimiento español: un material simbólico" en Boletín del Museo e Instituto "Camón Aznar". Editor Museo e Instituto Camón Aznar, nº XLII, 1990, pp.31-57.

- BARRIOS ROZÚA, Juan Manuel.[1998] Reforma urbana y destrucción del patrimonio histórico en Granada. Ciudad y desamortización. Editorial Universidad de Granada, Granada, 1998.

- BASABÉ, E.[1961] "Jerónimo y los clásicos paganos" en Helmática, 2, 1961, pp.161-192. 
- Bienes inmuebles protegidos en las capitales andaluzas.[2000] Instituto Andaluz del Patrimonio Histórico, publicación trimestral electrónica. Año I, marzo 2000, Sevilla.

- BOBADIlla CAMPOS, Fernando. F. de y OROZCO DÍAZ, Manuel.[1977] El Carmen de los Mártires (apuntes para "una historia..."). Edita: Fernando F. de Bobadilla, Granada, 1977.

- BOSQUE MAUREL, Joaquín. [1988] Geografía urbana de Granada, Universidad de Granada, Granada, 1988.

- BRAÑA DE DIEGO, María.[1973] "La cerámica en los monasterios de la Orden Jerónima" en Studia Hieronimyana, Madrid, 1973, vol. II, pp.297-307.

- BRAUNFELS, W.[1975] Arquitectura monacal en Occidente. Barcelona, 1975.

- CACERES PLA, Francisco de Paula.[1918] "De un libro curioso" en Revista La Alhambra, n 476, 31 de enero, 1918.

- CALATRAVA, Juan. [1991]"Arquitectura de Granada en las noticias de Llaguno y Ceán: 1829" en Revista del Centro de Estudios Históricos de Granada y su Reino, n 5, Granada, 1991, pp. 189-203.

- CAMÓN AZNAR, José. [1964] "La arquitectura y la orfebrería españolas del siglo XVI" en Summa Artis, Historia General del Arte, vol. XVII. Ed. Espasa Calpe, S.A, Madrid, 1964.

- CASTILlo OREJA, Miguel Ángel. [1992] Renacimiento y Manierismo en España, Historia del Arte, vol.28. Historia 16, Madrid, 1992.

- CASTILlO RUIZ, José. [1992] "Evolución histórica del entorno del monasterio de San Jerónimo: su dimensión urbana" en Cuadernos de Arte de la Universidad de Granada, núm. XXIV. Ed. Universidad de Granada, Granada, 1992, pp.257-276.

- CASTILlO RUIZ, José. [1997] El entorno de los bienes inmuebles de interés cultural. Universidad de Granada e Instituto Andaluz del Patrimonio Histórico, Granada, 1997.

- CERRO BEX, Victoriano del [2000] "Fray Hernando de Talavera" en Catálogo de la exposición Jesucristo y el Emperador cristiano, celebrada en la Catedral de Granada con motivo del año jubilar de la Encarnación de Jesucristo y del $\mathrm{V}$ centenario del nacimiento del 
emperador Carlos, Granada 8 de julio al 8 de diciembre, Publicaciones Obra Social y Cultural de Cajasur, Córdoba, 2000, pp.515-518.

- CID ACEDO, Aurelio y SÁNCHEZ-MESA MARTÍN, Domingo. [1989] Granada, Ed. Capitel, Granada, 1989.

- COLINA MUNGUÍA, Saturnino.[1964] "En Granada surge una torre" en diario Patria, 13 de Noviembre 1964, p.15.

- COlina MUNGUIA, Saturnino.[1986] Monasterio de San Jerónimo de Granada. Editorial Everest, S.A. León, 1986.

- COLOMBAS, G.M. [1963]"Vida y espíritu de los monjes jerónimos" en Yermo, vol. I, núm. 3, 1963, pp. 371-381.

- CHECA, Antonio. [1970] “¿Una violación a las Ordenanzas Municipales?" En Ideal, jueves 12 de febrero, Granada, 1970., p.7.

- CHECA CREMADES, Fernando [1983] Pintura y Escultura del Renacimiento en España (1450-1600), Ed. Cátedra, Madrid, 1983.

- CHUECA GOITIA, Fernando. [1982] Casas reales en monasterios y conventos españoles. Ed. Xarait, Madrid, 1982.

- CHUECA GOITIA, Fernando.[1953] "Arquitectura del siglo XVI" en Ars Hispaniae, Historia Universal del Arte, vol.XI. Ed. Plus Ultra, Madrid, 1953.

- D'ALLERIT, O. [1968]"En torno a la espiritualidad jerónima" en Yermo, vol.6, 1968, pp. 199-210.

- DAVID INGLIS, Henry. [1955] Granada en 1830. Traducción, prologo y notas de Alfonso Gamir Sandoval. Ediciones CAM, Granada, 1955.

- DÍAZ-CANEJA, Moisés.[1947] Arte y Liturgia. Artes Gráficas Grijelmo, Bilbao, 1947.

- DUCHET-SUCHAUX, Gaston y PASTOUREAU, Michael. [1996]. Guía iconográfica de la Biblia y los santos, Alianza Editorial, Madrid, 1996.

- EISMAN LASAGA, Carmen. [1991]"Vicisitudes por las que atravesó el Patrimonio Inmueble de Granada como consecuencia de la destrucción artística del período revolucionario" en Cuadernos de Arte de la Universidad de Granada, núm. XXI, Granada, 1991. 
- EISMAN LASAGA, Carmen. [1991]"Efectos que produjo la invasión francesa en los conventos de Granada" en Cuadernos de Arte de la Universidad de Granada, núm.XXII, Granada, 1991, pp.63-73.

- "El Monasterio de San Jerónimo devuelto a esta Orden" en Ideal, 24 de julio, Granada, 1973, p.10.

- FÉLEZ ZUBELZA, Concepción y LÓPEZ GUZMAN, Rafael. [1990]"Arquitectura en Andalucía Oriental" en El Arte del Renacimiento, Urbanismo y Arquitectura. Historia del Arte en Andalucía, vol. IV. Ed. Gever, S.L, Sevilla, 1990.

- FERRER GARROFÉ, Paulina.[1999] "Observaciones sobre la imagen de San Jerónimo penitente en la escultura sevillana. De Torrigiano a Martínez Montañes" en La Orden de San Jerónimo y sus Monasterios. Espiritualidad, historia, arte, economía y cultura de una Orden religiosa ibérica, Actas del Simposium (I). Estudios Superiores del Escorial. San Lorenzo del Escorial (Madrid), 1999, p. 413-427.

- FORD, Richard.[1955] Granada, escritos con dibujos inéditos del autor. Traducción y notas de Alfonso Gámir, Patronato de la Alhambra, Granada, 1955.

- FORD, Richard [1980] Manual para viajeros por Andalucía y lectores en Casa, Ed. Turner, Madrid, 1980.

- GALLEGO Y BURÍN, Antonio. [1918] "Diferencias entre Diego de Siloé y el Duque de Sessa" en Revista La Alhambra, núm. 477, 15 de febrero de 1918, Granada, pp. 64-65.

- GALlegO Y BURÍN, Antonio. [1937] "Dotación de los Reyes Católicos a las iglesias erigidas en Granada" en Cuadernos de Arte de la Universidad de Granada, Granada, 1937.

- GALlego Y BURÍN, Antonio. [1948] Lo barroco y el barroco en Granada. Ed. Universidad de Granada, Granada, 1948.

- GAllego Y BURÍN, Antonio. [1996] Granada. Guía artística e histórica de la ciudad. Editorial Comares, Granada, 1996.

- GAYA NUÑO, Juan Antonio. [1958] La pintura española fuera de España (Historia y Cátalogo). Ed. Espasa-Calpe. S.A, Madrid, 1958.

- GIL, Rodolfo.[1992] El país de los sueños: páginas de Granada. Ed. Albaida, Granada, 1992. 
- GIMÉNEZ SERRANO, José [1846] Manual del artista y del viajero en Granada, Imprenta de Puchol, Granada, 1846.

- GOMEZ-MORENO CALERA, José Manuel. [1989]"El licenciado Làzaro de Velasco: pintor de libros y arquitecto: aproximación a su biografía y obra" en Boletín de Arte, Departamento de Historia del Arte, Universidad de Málaga, Málaga, 1989, núm. 10, pp.75-92.

- GÓMEZ-MORENO CALERA, José Manuel. [1989] La arquitectura religiosa granadina en la crisis del renacimiento (1560/1650). Universidad de Granada y Diputación Provincial, Granada, 1989.

- GÓMEZ-MORENO GONZÁLEZ, Manuel [1884] "Breve reseña de las pérdidas que ha experimentado Granada en lo que vá de siglo" en La Alhambra, 29-31, Granada, 1984.

- GÓMEZ-MORENO MARTÍNEZ, Manuel. [1994]Guía de Granada (Tomo I)., Ed. Universidad de Granada. Granada, 1994.

- GÓMEZ-MORENO MARTÍNEZ, Manuel. [1984] "Breve reseña de las pérdidas que Granada ha experimentado en sus monumentos y obras de arte en lo que va de siglo" en La Alhambra, núm. 29, 20 de octubre de 1984, pp.1-3.

- GÓMEZ-MORENO MARTÍNEZ, Manuel. [1983] Las águilas del Renacimiento español: Ordoñez, Siloé, Machuca, Berruguete. Ed. Xarait, Madrid, 1983.

- GÓMEZ-MORENO MARTÍNEZ, Manuel y GÓMEZ-MORENO CALERA, José Manuel.[1988] Siloé. (ed. Facsímil). Ed. Universidad de Granada, Granada, 1988.

- GÓMEZ OLIVER, Miguel. [1981] La desamortización de Mendizabal en Granada, Granada, 1981.

- Granada Artística, Corpus Christi año1940. Programa de las Tradicionales Fiestas con motivo del día del Santísimo Corpus Christi que se celebrarán del 22 de mayo al 2 de junio. Imprenta de Francisco Román, Granada, 1940.

- GRANADINO ENTUSIASTA DEL CENTENARIO, UN. "La espada de Francisco I y el monasterio de San Jerónimo" en Revista La Alhambra, Granada, núm. 241, 30 de marzo, pp. 123-126.

- GUTIÉRREZ-CORTINES CORRAL, C. [1987], Arquitectura, economía e Iglesia en el siglo XVI, Ed. Xarait, Bilbao, 1987. 
- GUTIÉRREZ GARCÍA, Ana María y HERMOSO ROMERO, Ignacio. [2000] "Un museo privado en Granada: el Museo de los Mártires" en Actas del XIII Congreso Español de Historiadores del Arte, Editorial Comares, S.L, Granada, 2000, pp. 287-298 (vol.I)

- HENARES CÚELLAR, Ignacio. [1982] Granada. Diputación de Granada, Granada, 1982.

- HENARES CUÉLLAR, Ignacio. [1992] "Arquitectura y Mecenazgo" en La Arquitectura del Renacimiento en Andalucía, Andrés de Vandelvira y su época. Consejería de Cultura y Medio Ambiente, Junta de Andalucía, Sevilla, 1992.

- HENARES CUELLAR, Ignacio [2000] "Los modelos del Clasicismo y el Humanismo cristiano en la Granada Moderna" en Catálogo de la exposición Jesucristo y el emperador cristiano, celebrada en la Catedral de Granada con motivo del año jubilar de la Encarnación de Jesucristo y del $\mathrm{V}$ centenario del nacimiento del emperador Carlos, Granada 8 de julio al 8 de diciembre, Publicaciones Obra Social y Cultural de Cajasur Córdoba, 2000, pp, 61-65.

- ISAC MARTÍNEZ DE CARVAJAL, Ángel. [1987] "Transformación urbana y renovación arquitectónica en Granada: del "plan geométrico" (1846) al Gran Parque (1929)" en Cuadernos de Arte, núm. XVIII, Universidad de Granada, Granada, 1987.

- HERNÁNDEZ DÍAZ TAPIA, María Concepción. [1976] Los Monasterios de Jerónimas en Andalucía. Anales de la Universidad Hispalense. Filosofía y Letras. Universidad de Sevilla, Sevilla, 1976.

- ISLA MINGORANCE, Encarnación. [1987] "Estado actual en que se encuentran las fachadas de piedra de la iglesia de San Jerónimo" en Cuadernos de Arte de la Universidad de Granada, núm. XVIII, 1987, pp.178-187.

- JAUREguizAR, E. [1949] "San Jerónimo y los clásicos" en Helmántica. I, 1949.

- JUANINI CUESTA.[1950] "El sueño de San Jerónimo" en Helmántica, 1950, pp.89-101.

- JEREZ MIR, Carlos. [1996] Guía de arquitectura de Granada, Junta de Andalucía, Granada, 1996.

- KAGAN, Richard L. (Dir.). [1986]Ciudades del Siglo de Oro. Las vistas españolas de Anton Van den Wyngaerde. Ed. El Viso, Madrid, 1986. 
- KUBLER, George. [1957]"Arquitectura de los siglos XVII y XVIII" en Ars Hispaniae. T.XIV, Madrid, 1957.

- LAFUENTE ALCÁNTARA, Manuel [1849] El Libro del Viajero en Granada, Imprenta de D. Luis García, Madrid, 1849.

- LAFUENTE AlCANTARA, Miguel. [1993] Historia de Granada, Universidad de Granada, 1993.

- LADERO QUESADA, M.A.[1986] "Mecenazgo Real y nobiliario en monasterios españoles: los jerónimos (siglos XV y XVI)" en Príncipe de Viana, 1986.

- LÓPEZ GUZMÁN, Rafael. [1991] El Renacimiento en Granada. Cuadernos de Arte Español de Historia 16, número 18. Madrid 1991.

- LÓPEZ GUZMÁN, Rafael. [1992] "El lenguaje arquitectónico en el Renacimiento andaluz" en La Arquitectura del Renacimiento en Andalucia, Andrés de Vandelvira y su época. Consejería de Cultura y Medio Ambiente, Junta de Andalucía, Sevilla, 1992.

- LÓPEZ-YARTO ELIZALDE, Amelia.[1999] "Consecuencias de la desamortización en el patrimonio artístico de los monasterios jerónimos españoles" en La Orden de San Jerónimo y sus Monasterios. Espiritualidad, historia, arte, economía y cultura de una Orden religiosa ibérica, Actas del Simposium (II). Estudios Superiores del Escorial. San Lorenzo del Escorial (Madrid), 1999, pp. 809-823.

- LOZANO NAVARRO, Julián José [2000] "Fray Pedro Ramiro de Alba, Arzobispo de Granada" en Catálogo de la exposición Jesucristo y el emperador cristiano, celebrada en la Catedral de Granada con motivo del año jubilar de la Encarnación de Jesucristo y del $\mathrm{V}$ centenario del nacimiento del emperador Carlos, Granada 8 de julio al 8 de diciembre, Publicaciones Obra Social y Cultural de Cajasur Córdoba, 2000, pp.535-537.

- LUQUE, J y GARRIDO, M. [1858] Manual histórico descriptivo de Granada, Imprenta Garrido, Granada, 1858.

- MADOZ PASCUAL, José. [1845-1850] Diccionario geográfico, estadístico e histórico de España y sus posesiones de ultramar, Madrid, 1845-1850.

- MADRID, Fray Ignacio de, OSH. [1967] "Los monasterios de la Orden de San Jerónimo en España" en Yermo, vol.5, núm. 2, 1967, pp. 107-175. 
- MADRID, Fray Ignacio de, OSH. [1976] "El trabajo en la Orden de San Jerónimo" en Santa María del Paular. Vol. 13, 1-2, 1976, pp.173199

- MADRID, Fray Ignacio de, OSH.[1999] "La Orden de San Jerónimo en perspectiva histórica" en La Orden de San Jerónimo y sus Monasterios. Espiritualidad, historia, arte, economía y cultura de una Orden religiosa ibérica, Actas del Simposium (I). Estudios Superiores del Escorial. San Lorenzo del Escorial (Madrid), 1999, pp.8-38.

- MARÍAS FRANCO, Fernando. [1989] El largo siglo XVI, Ed. Taurus, Madrid, 1989.

- MARÍAS FRANCO, Fernando [1992] El siglo XVI. Gótico y Renacimiento, Ed. Silex, Madrid 1992.

- MARÍN LÓPEZ, Rafael. [2001] "El convento de Santa Paula" en Ideal, 30 de marzo de 2001, p.21.

- MARTÍN GONZÁLEZ, Juan José [1975] El Ayer, ante nosotros. Sobre la conservación y ambientación de nuestros monumentos y conjuntos histórico-artísticos, Ed. Server-Cuesta, Valladolid, 1975.

- MARTÍN GONZÁLEZ, Juan José [1978] "Problemática de la desamortización en el arte español" en II Congreso Español de Historia del Arte, 1978, Valladolid. pp.15-29.

- MARTÍNEZ MEDINA, Francisco Javier. [1989] Cultura religiosa en la Granada Renacentista y Barroca, Ed. Universidad de Granada, Granada, 1989.

- MARTÍNEZ MEDINA, Francisco Javier [1993] "Los conventos de Granada" en Nuevos Paseos por Granada y su contorno, Caja General de Ahorros, Granada, 1993. pp, 287-307.

- MARTINO ALBA, Pilar. [1999] "Noticias sobre los monasterios jerónimos en los relatos de viajeros alemanes" en La Orden de San Jerónimo y sus Monasterios. Espiritualidad, historia, arte, economía y cultura de una Orden religiosa ibérica, Actas del Simposium (II). Estudios Superiores del Escorial. San Lorenzo del Escorial (Madrid), 1999, pp. $847-890$

- MATEO GÓMEZ, Isabel, PRADOS GARCÍA, José María y LÓPEZYARTO ELIZALDE, Amelia. [1999] El Arte de la Orden Jerónima, Ed. Iberdrola, Bilbao, 1999. 
- Memoria comprensiva de los trabajos verificados por las Comisiones de Monumentos Históricos y Artísticos del Reino desde el 1 de julio de 1844 hasta igual fecha de 1845, Imprenta Nacional, Madrid, 1845.

- Memoria de las Actas y trabajos de la Comisión de Monumentos Históricos y Artísticos de la Provincia de Granada, desde su instalación en 20 de mayo de 1866 hasta fin de 1867, Imprenta de D. José Zamora, Granada, 1868.

- MÉNDEZ DE VIFO, I. [1862] Breve recuerdo histórico de Granada y rápida reseña de los edificios y monumentos más notables que existen en ella, Imprenta de Gerónimo Alonso, Granada, 1862.

- Miller PROFUMO, Luciana. [1985] El ornamento icónico y la arquitectura 1400-1600. Ed. Catedra, Madrid, 1985.

- MOLINA FAJARDO, Eduardo. [1982] Granada en color, Ed. Everest, León, 1982.

- Monumentos Españoles. Catálogo de los Declarados HistóricoArtísticos 1844-1953. [1984] Tomo I, tercera edición. Ministerio de Cultura, Dirección General de Bellas Artes y Archivos, Madrid, 1984.

- MORALES MARTÍNEZ, Alfredo J. [1992] "La otra arquitectura" en La Arquitectura del Renacimiento en Andalucía, Andrés de Vandelvira y su época. Consejería de Cultura y Medio Ambiente, Junta de Andalucía, Sevilla, 1992.

- MORENO, Francisco. [1986] San Jerónimo. La espiritualidad del desierto. Madrid, 1986.

- MORENO OLMEDO, María Angustias.[1988] "Monasterio de Nuestra Señora de la Concepción de la Orden Jerónima de Granada: sus privilegios" en Cuadernos de la Alhambra, núm. 24, Patronato de la Alhambra y Generalife, Granada, 1988, pp. 143-149.

- MOXÓ, S. de. [1961] "Las desamortizaciones eclesiásticas del siglo XVI" en Anuario de Historia del Derecho Español, XXXI, 1961, pp.327-361.

- MÚNZER, Jerónimo. [1924] "Viaje por España y Portugal en los años 1494 y 1495. Versión en latín por Julio Puyol" en Boletín de la Real Academia de la Historia. Vol, LXXXIV, 1924, pp. 32-119.

- MUÑOZ COSME, Alfonso [1989] La conservación del Patrimonio arquitectónico español, Ministerio de Cultura, Madrid, 1989. 
- NAVAGERO, Andrea. [1983] Viaje por España 1524-1526. Traducido y anotado por Antonio María Fabié. Ed. Turner, S.A, Madrid, 1983.

- NAVASCUÉS PALACIO, Pedro [1987] "La restauración monumental como proceso histórico: el caso español (1800-1950)" en Curso de Mecánica y Tecnología de los edificios antiguos, Dirección General de Arquitectura, Madrid, 1987.

- $\quad$ NIETO, Víctor, MORALES, Alfredo J., CHECA, Fernando. [1986] Arquitectura del Renacimiento en España, 1488-1599. Ed. Catedra, Madrid, 1986.

- $\quad$ "Ordenes religiosas" [1985] en Antiquaria, junio, 1985, núm. 19.

- OROZCO DIAZ, Emilio. [1975] "El antiguo colegio de Gramática y Música de Granada" en Boletín de la Real Academia de Bellas Artes de San Fernando núm.41, Real Academia de Bellas Artes de San Fernando, Madrid, 1975 pp.67-68.

- OROZCO DÍAZ, Emilio. [1975] El Museo de Bellas Artes - I- Pintura. Edita: Obra Cultural de la Caja de Ahorros de Granada, Granada, 1975.

- OROZCO DÍAZ, Emilio. 1975] El Museo de Bellas Artes- IIEscultura. Edita: Obra Cultural de la Caja de Ahorros de Granada, Granada, 1975.

- OROZCO DIAZ, Manuel. [1993] "Meditación en torno a unas esculturas en la Casa de los Tiros: en relación con el Monasterio de San Jerónimo" en Boletín de la Real Academia de Bellas Artes Nuestra Señora de las Angustias, núm.3, mayo, Granada, 1993.

- OROZCO PARDO, José Luis. [1985] Christianópolis: urbanismo y contrarreforma en la ciudad del seiscientos. Diputación de Granada, Granada, 1985.

- PALOMINO URDA, Pablo y PALACIOS, Joaquín.[1986] Estudio del estado actual de la fachada en piedra de la iglesia de San Jerónimo de Granada. Universidad de Granada, Escuela de Arquitectura Técnica, Granada, 1986.

- Patria, sábado 18 de mayo, 1957.

- PENNA, A. San Jerónimo. Barcelona, 1952.

- PEÑA BERCEDO, Justiniano. [1957] Actuación de San Jerónimo en la conciliación de las culturas pagana y cristiana, Burgos, 1957. 
- PÉREZ DE URBEL, [1920]"Influencias de San Jerónimo en los Padres de la Iglesia Española" en Revista Eclesiástica, núm. 47, 1920.

- PÉREZ SÁNCHEZ, Alfonso E. [1982] Pintura Barroca en España 1600-1750. Ediciones Cátedra, S.A, Madrid, 1982.

- PI Y MARGALL, F. [1850] Recuerdos y bellezas de España. Reino de Granada, Ed. Repullés, Madrid, 1850.

- PICASTOTE, V. [1898] Descripción e historia política, eclesiástica y monumental de España. Provincia de Granada, Imprenta de Hernando, Madrid, 1898.

- PIVA, Antonio [1990] "Rehabilitación de edificios antiguos para su conversión en Museos" en Monumentos y Proyecto. Jornadas sobre criterios de intervención en el Patrimonio arquitectónico, Ministerio de Cultura, Madrid, 1990.

- PRIETO-MORENO PARDO, Francisco. [1979] Planimetría del Monasterio e Iglesia de San Jerónimo, Granada, 1979. Planos facilitados por la Delegación de la Consejería de Cultura de la Junta de Andalucía.

- QUINTERO ATAURI, Pelayo. [1908] "Sillas de coro españolas" en Boletín de la Sociedad Española de Excursiones, XVI, primer trimestre, Madrid, 1908, pp. 16-23.

- REVILlA UCEDA, Mateo.[1980] "El centro histórico y la Universidad" en Arquitectura, Andalucía Oriental, Marzo, 1980.

- RIEGL, Aloïs [1987] El culto moderno a los monumentos. Caracteres y origen, Ed. Visor, Madrid, 1987.

- RINCÓN GARCÍA, Wilfredo. [1992] Monasterios de España. Vol. II, Madrid, 1991, Vol. III, Madrid, 1992.

- ROMAN PASTOR, C. [1988] Arquitectura conventual en Alcalá de Henares (siglos XVI-XIX), Universidad Complutense, Madrid, 1988.

- ROMERO TORRES, Justo. [1999] "Contrarreforma e iconografía de San Jerónimo: realidad y leyenda" en La Orden de San Jerónimo y sus Monasterios. Espiritualidad, historia, arte, economía y cultura de una Orden religiosa ibérica, Actas del Simposium (I). Estudios Superiores del Escorial. San Lorenzo del Escorial (Madrid), 1999, pp.383-405. 
- RUBIO GONZÁLEZ, Lorenzo. [1976] "La Orden de San Jerónimo en España" en Studio Agustiniano. Vol. XI, II, 1976, pp. 261-271.

- RUIZ HERNANDO, José Antonio. [1997] Los monasterios jerónimos españoles. Caja-Segovia, Segovia, 1997.

- RUIZ RICO, José Manuel. (Coord.) [1996] Leyes civiles especiales. Ed. Comares, Granada, 1996.

- SAINZ DE ROBLES, F.[1953] Monasterios de España, Madrid, 1953.

- SALAS, X. de. [1967] "Noticias de Granada reunidas por Ceán Bermúdez" en Cuadernos de Arte y Literatura, 1967, núm. 1, pp. 140142.

- SAlOMÓN, R. [1872] Guía del viajero en Granada, Imp. Paulino Ventura, Granada, 1872.

- SAN JeRÓNimo. [1962] Cartas. 2vols., Biblioteca de Autores Cristianos, Madrid, 1962.

- SIGÜENZA, fray José. [1989] Historia de la Orden Jerónima, Nueva Biblioteca de autores españoles, Madrid, 1989.

- TORRES BALBÁS, Leopoldo [1918] "La restauración de los monumentos antiguos" en Revista Arquitectura, I, Madrid, 1918.

- TORRES BALBÁS, Leopoldo. [1919] "Los monumentos Histórico y Artísticos: destrucción y conservación. Legislación y organización de sus servicios y su inventario". VIII Congreso Nacional de Arquitectos, Zaragoza, Tip, La Editorial, 1919.

- TORRES BALBÁS, Leopoldo. [1920] "La utilización de Monumentos antiguos" en Revista Arquitectura, Tomo III, Madrid, 1920.

- TORRES BALBÁS, Leopoldo. [1982] "Los contornos de las ciudades hispanomusulmanas" en Obra dispersa. I. Al-Andalus. Crónica de la España musulmana. Instituto de España, Madrid, 1982.

- ULLED MERINO, Antonio de J. (Dir.) [1986] La recuperación de edificios históricos para usos turísticos, la experiencia española. Ed. Tecniberia, Asociación para la promoción de la ingeniería, la consultoría y la investigación españolas en el exterior, Madrid, 1986.

- VALLADAR, Francisco de Paula. [1906] La Iglesia de San Jerónimo. Estudio histórico, Granada, 1906. 
- VALLADAR, Francisco de Paula. [1906] "La Iglesia de San Jerónimo. II" en Alhambra, año IX, 15 de septiembre de 1906, Granada, 1906.

- VAlladar y SERRANO, Francisco de Paula. [1906] Guía de Granada: historia, descripciones, artes, costumbres, investigaciones arqueológicas. Editor Paulino Ventura Traveset, Granada, 1906.

- VAlladar Y SERRANO, Francisco de Paula. [1908] "Crónica granadina: otra vez San Jerónimo" en Revista La Alhambra, núm. 239, 29 de febrero de1908, pp.95-96.

- VAlladAR, Francisco de Paula. [1913] "Crónica granadina" en Alhambra, año XVI, núm. 360, Granada, 1913.

- VALLADAR, Francisco de Paula. [1916]"El templo de San Jerónimo" en Alhambra, año XIX, núm. 434, Granada, 1916.

- Valladar, Francisco de Paula. [2000] Guía de Granada (Estudio preliminar de Juan Manuel Barrios Rozua), Edición Facsímil, Universidad de Granada y Ed. Comares, Granada, 2000.

- VIGON JORGE, José. [1944] El Gran Capitán. Ed. Atlas, Madrid, 1944.

- VILLAFRANCA JIMÉNEZ, $\mathrm{M}^{\mathrm{a}}$ del Mar [1992] "Inventarios y Catálogos del Museo Provincial de Bellas Artes de Granada realizados en el siglo XIX: análisis y valoración" en Cuadernos de Arte de la Universidad de Granada, núm. XXIII, Granada, 1992.

- VILlAFRANCA JIMÉNEZ, $\mathrm{M}^{\mathrm{a}}$ del Mar. [1998] Los museos de Granada: génesis y evolución histórica (1835-1975). Diputación de Granada, Granada, 1998.

- VIÑES MILLET, Cristina [1982] Granada en los libros de viaje, Granada, 1982.

- YAÑEZ, Domingo Luis. [1991] Iniciación a las restauraciones pétreas. Ed. Caja General de Ahorros y Monte de Piedad, Granada, 1991. 
2. Bibliografía sobre Museología y Museografía empleada en la redacción del Proyecto.

- ABBEY, D.S. [1986]"La exposición como un instrumento educativo" en Museum, núm. 151, 1986, pp. 191-203.

- ADELL CALDUCH, Joaquín [1986] “¿Luz para los museos? ¿Luz para el arte?...Hágase la luz.”, Erco Iluminación, pp.84-88.

- ADELL CALDUCH, Joaquín [1993] "Una propuesta para la iluminación de pinturas en: museos, salas de exposiciones temporales y galerías de arte" en XIX Simposium de alumbrado, Asturias 26-28 de mayo de 1993

- ADELL CALDUCH, Joaquín [1999] "Práctica de la gestión y mantenimiento del alumbrado en los museos: una aproximación" Erco Iluminación, pp.1-12.

- AGUILAR CORREDERA, Francisco, PAVÓN RENDÓN, Joaquín y VALVERDE CUEVAS, Fernando. [1997] Régimen jurídico del Patrimonio Histórico en Andalucía. Consejería de Cultura, Junta de Andalucía, Sevilla, 1997.

- ALONSO FERNÁNDEZ, Luis [1988] Museos y Museología, dinamizadores de la cultura de nuestro tiempo, Universidad Complutense, Madrid, 1988.

- ALONSO FERNÁNDEZ, Luis. [1993] Museología. Introducción a la teoría y práctica del museo. Ed. Istmo, Madrid, 1993.

- ALONSO FERNÁNDEZ, Luis. [1999] Museología y Museografía. Ediciones del Serbal, Barcelona, 1999.

- ALONSO FERNÁNDEZ, Luis y GARCÍA FERNÁNDEZ, Isabel. [1999] Diseño de exposiciones. Concepto, instalación y montaje. Alianza Editorial, S.A, Madrid 1999.

- AlONSO IBÁÑEZ, M.R [1992] El patrimonio histórico. Destino público y valor cultural, E. Civitas, Madrid, 1992.

- ALONSO LÓPEZ, Ma José. [1995] "Día Internacional del Museo. Museos entre bastidores, respuesta y responsabilidad: Conservación en los museos" en Pátina, núm. 7, junio, 1995, pp. 156-158. 
- AMÉRIGO, Ma . [1993] "Metodología de cuestionarios: principios y aplicaciones, Boletín de ANABAD, núm. 43, 1993, pp. 263-272.

- BAGLIONI, Raniero. [1998] "La iluminación de un bien cultural: problemas conservativos y nuevos avances" en Boletín del Instituto Andaluz del Patrimonio Histórico núm. 23, julio 1998, pp.51-62.

- BAGLIONI, Raniero. [1996] "Vitrina de conservación del esmalte denominado Tríptico del Gran Capitán del Museo de Bellas Artes de Granada. Proyecto y realización" en Boletín del Instituto Andaluz del Patrimonio Histórico núm.15, año IV, Junio 1996, pp.75-82.

- BAGLIONI, Raniero. [2001] Nuevas técnicas de conservación preventiva aplicadas a los bienes culturales. Curso organizado por el Instituto Andaluz del Patrimonio Histórico en colaboración con la Asociación de Amigos del Museo de Artes y Costumbres Populares de Sevilla, Sevilla, Enero 2001. [Inédito]

- BAZTÁN LACASA, Carlos. [1999]"Museos en monumentos. Una pequeña historia y treinta ideas" en Revista de Museología núm. 17, Junio 1999, pp.25-31.

- BERNADES I POSTILS, Jaume. [1997] "La conservación preventiva: ¿Qué, cómo y por qué? en Actas del Coloquio Internacional "La conservación preventiva de bienes culturales", ICOM, Comité Español, Vigo, 1997, pp.49-77.

- BRANDI, Cesare [1988] Teoría de la restauración, Alianza Ed., Barcelona, 1988.

- BRAVO JUEGA, Ma Isabel. [1982] Un capitulo fundamental de la Museología: La seguridad en los museos. Edita, Asociación Española de Archiveros, Bibliotecarios, Museólogos y Documentalistas (ANABAD), Madrid, 1982.

- BUCES, José Antonio y Juan Antonio HERRÁEZ. [1999] "El almacén de bienes culturales" en Los Conocimientos técnicos. Museos, Arquitectura. Arte (edición de Juan Carlos Rico), Ed. Silex, Madrid, 1999; pp.407-432.

- CABALlERO ZOREDA, Luis. [1982] Funciones, organización y servicios de un Museo: El Museo Arqueológico Nacional. Edita: Asociación Española de Archiveros, Bibliotecarios, Museólogos y Documentalistas (ANABAD), Madrid, 1982. 
- CABAlLERO ZOREDA, Luis. [1983] "A propósito del Sistema de Documentación para Museos" en Boletín de ANABAD, XXXIII, núm. 3, 1983, pp. 493-500.

- CAlvo, Ana [1997] Conservación y restauración. Materiales, técnicas y procedimientos. De la A a la Z. Editorial El Serbal, Barcelona, 1997.

- CARRETERO PÉREZ, A. [1990] "Informatización y Catálogos documentales del Museo Nacional del Pueblo Español" en Anales del Museo del Pueblo Español, T.III, Madrid, 1990, pp.239-193.

- CARRIER, Christian. [1996] "La exposición como media. Análisis de un lenguaje" en Difusión del Patrimonio Histórico, Cuadernos de Instituto Andaluz del Patrimonio Histórico. Consejería de Cultura, Junta de Andalucía, Sevilla 1996, pp.60-69.

- COLOMA MARTÍN, Isidoro. [1990] "La iluminación: un problema primario en la exhibición museística" en Boletín de Arte, núm. 11. Departamento de Historia del Arte, Universidad de Málaga, 1990.

- CRISOSTOMI, Paolo y BAGLIONI, Raniero. [1986] Conservazione dei beni culturali in ambito museografico. Lavoro svolto per conto della Jacorossi s.p.s. nell'ambito del Progetto "MUSA", art.15, Legge Financiaría, 1986.

- El museo como foco cultural en la ciudad, [1990] VII Congreso Internacional de la Federación Mundial de Amigos de los Museos (Córdoba, 1990), Federación Mundial de Amigos de los Museos y Junta de Andalucía, Madrid, 1991.

- El patrocinio empresarial de la cultura en España, [1992] Ministerio de Cultura, Madrid, 1992.

- FERNÁNDEZ ARENAS, J. [1997] Introducción a la conservación del patrimonio y técnicas artísticas, Ed. Ariel, Barcelona, 1997.

- FERRIOT, Dominique. [1995] "Las reservas en los museos: un coloquio internacional" en Museum Internacional, núm.188 (vol.47, núm.4, 1995), UNESCO, 1995, pp.35-39.

- GARCÍA BLANCO, Ángela. [1981] "Didáctica del museo: el montaje didáctico" en Boletín de la Asociación Nacional de Archiveros, Bibliotecarios, Arqueólogos y Documentalistas, (ANABAD), XXXI, 1981, núm. 3. 
- GARCÍA BLANCO, Ángela. [1988] Didáctica del Museo. El descubrimiento de los objetos. Ediciones de la Torre, Madrid, 1988.

- GARCÍA BLANCO, Ángela. [1999]La exposición, un medio de comunicación. Ediciones Akal, S.A, Madrid, 1999.

- GARCÍA BLANCO, Ángela. [1990] "Educación y comunicación en el museo: la exposición" en Boletín del Museo Arqueológico Nacional (Madrid) VIII, 1990, pp. 17-28.

- GARCÍA BLANCO, Ángela, ASENSIO BROUARD, Mikel y POL MÉNDEZ, Elena. [1992]"El público y la exposición. ¿Existen dificultades de comprensión? en Boletín del Museo Arqueológico Nacional, X, 1992, Madrid, pp.93-106.

- GARDINER, Graeme. [1994] "Más vale prevenir que curar: preservación vs. conservación” en Museum Internacional, núm. 183 (vol.46, núm.3, 1994), pp.54-56.

- GARCÍA FERNÁNDEZ, Isabel María [1999] La conservación preventiva y la exposición de objetos y obras de arte. Editorial K.R, Murcia, 1999.

- GARCÍA MORALES, María [2000] La Conservación preventiva en los museos. Teoría y práctica. Organismo Autónomo de Museos y Centros, Cabildo de Tenerife, Tenerife, 2000.

- GÓMEZ GONZÁLEZ, Ma Luisa [1998] La Restauración. Examen científico aplicado a la conservación de obras de arte. Ediciones Cátedra, Madrid, 1998.

- GONZÁlEZ VARAS, Ignacio [1999] Conservación de Bienes Culturales. Teoría, historia, principios y normas, Ed. Cátedra, Madrid, 1999.

- GUICHEN, Gaël de. [1983] Conservazione preventiva nei musei. Il controllo dell 'illuminazione. Il controllo del clima, ICCROM, Instituto Centrale del Restauro, Roma, 1983.

- GUICHEN, Gaël de. [1984] "Enseñar a conservar el patrimonio" en Museum, núm. 144, 1984, pp. 232-233.

- GUICHEN, Gaël de. [2001] "La conservación preventiva, del sueño a la realidad", conferencia del Seminario Internacional "Museos, visiones y reflexiones", febrero 2001, Granada. 
- HANSEN, T. [1984] "El Museo como educador" en Museum, núm. 144, 1984.

- HERNÁNDEZ HERNÁNDEZ, Francisca. [1988] Manual de Museología. Ed. Síntesis, S.A, Madrid, 1988.

- HERNÁNDEZ HERNÁNDEZ, Francisca. [1998] El museo como espacio de comunicación. Ed. Trea, Gijón, 1998.

- HERRAEZ, Juan A. y RODRÍGUEZ LORITE, Miguel Ángel [1989] Manual para el uso de aparatos y la toma de datos de las condiciones ambientales en museo, Ministerio de Cultura, Madrid, 1989.

- HERRAEZ, Juan A. y RODRÍGUEZ LORITE, Miguel Ángel. [1991] Recomendaciones para el control de las condiciones ambientales en exposiciones temporales. Dirección General de Bellas Artes y Archivos. Instituto de Conservación y Restauración de Bienes Culturales, Ministerio de Cultura, 1991.

- HERREMAN, Yani. "El almacenamiento de colecciones en los museos: un problema no resuelto"en Museum, núm. 188, 1985, pp.812.

- HILBERT, Günter S. [1985] "La protección contra el robo y el vandalismo" en Museum, núm.146, 1985, pp.115-118.

- HOOPER-GREENHILL, Eilean. [1998] Los museos y sus visitantes. Ed. Trea, Gijón, 1998.

- LAVADO PARADINAS, P.J. [1983] "La función educativa de los museos europeos" en Universidad y Sociedad. Revista del Centro Regional de Madrid asociado a UNED, núm.7, Madrid, 1983, pp.145165.

- LAVADO PARADIMAS, P.J. [1988] "Etapas de la difusión cultural y educativa de los museos" en La investigación del educador de museos, Ayuntamiento de Barcelona, Barcelona, 1988, pp. 228-238.

- LAVADO PARADIMAS, P.J. [1989] "Un museo no tiene que ser aburrido", ICOM.I Encontro das Comissoes Nacionais Portuguesa e Española (Vila Viçosa Portugal, 1988), Portugal, 1989, pp. 293-305.

- LAVADO PARADIMAS, P.J. [1989] "Un museo es algo muy divertido" Talleres en el museo, Madrid, ed. del autor, 1989. 
- LAVADO PARADIMAS, P.J. [1990] "Venturas y desventuras de un visitante individual" en VII Jornadas DEAC Museos (1990), Madrid, 1992, pp. 67-75.

- LAVADO PARADIMAS, P.J. [1991] "El museo (im)posible. Un museo especial para visitantes especiales" en VIII Jornadas Estatales DEAC Museos (1991), Mérida, 1993, pp. 35-42.

- LEÓN, Aurora. [1990] El museo. Teoría, praxis y utopía. Ediciones Cátedra S.A, Madrid 1990.

- Ley 2/1984, de 9 de enero, de Museos de Andalucía (B.O.J.A., núm.4, de 10 de enero).

- Ley 16/1985, de 25 de junio, del Patrimonio Histórico Español (B.O.E, núm.155, de 29 de junio).

- Ley 1/1991, de 3 de julio, del Patrimonio Histórico de Andalucía. Normas reguladoras (B.O.JA., núm. 59, de 13 de julio).

- LIMÓN, Antonio. "La informatización de los repertorios documentales en museos: el paquete de programas ODISEUS" en Catalogación del Patrimonio Histórico, Cuadernos de Instituto Andaluz del Patrimonio Histórico. Consejería de Cultura, Junta de Andalucía, Sevilla, 19 pp.108-119.

- LIZANA RIVAS, E. [1988] "La tienda en los museos" en VI Jornadas Nacionales DEAC Museos (1988), Valladolid, 1988, pp. 167-168.

- LÓPEZ DE AGUILERA, Iñaki. [2000 ]Cultura y ciudad. Manual de política cultural municipal. Ed. Trea, Gijón, 2000.

- LORD, Barry y LORD, Gail Dexter. [1998] Manual de gestión de museos. Editorial Ariel S.A, Barcelona 1998.

- Los museos y los niños. [1983] Secretaría General Técnica, Ministerio de Cultura, Madrid, 1983.

- LUZÓN NOGUE, José Ma . [1991] "La documentación en los museos" en Boletín de ANABAD, XLI, 1991, pp. 406-413.

- MACUA, J.L. [1988] "Los elementos expositivos en la didáctica del museo" en IV Jornadas DEAC de Museos (1985), Madrid, 1988, pp. 63-68.

- MAGHERINI, G. [1990] El síndrome de Stendhal. Madrid, EspasaCalpe, 1990. 
- MAKAGIANSAR, M, de. "Museos de hoy y de mañana: una misión cultural y educativa" en Museum, núm. 141, pp. 3-7.

- MARCHENA GÓMEZ, Manuel y CARRASCO NIEVES, Gonzalo. [1996] "La promoción turística del patrimonio cultural en Andalucía" en Difusión del Patrimonio Histórico, Cuadernos de Instituto Andaluz del Patrimonio Histórico. Consejería de Cultura, Junta de Andalucía, Sevilla 1996, pp. 78-85.

- MARTÍN BLANCO, A. [1975] "La Conservación del Patrimonio Artístico Eclesiástico" en R.A.P, núm. 75, 1975.

- MARTÍN BOURGON, T. [1991] "La interdisciplinariedad en los programas de educación de los museos" en El museo como foco cultural en la ciudad, VII Congreso Internacional de la Federación de Amigos de los Museos (Córdoba, 1990), Madrid, Federación Mundial de Amigos de los Museos-Junta de Andalucía, 1991, pp.129-134.

- MARTÍN DELGADO, Rafael [2001] "Edificios antiguos y nuevos museos" Clase impartida en el Máster de Museología, Universidad de Granada, Granada, 2001 [Inédita]

- MARTÍN MARTÍN, F. [1994] "Reflexiones en torno al museo en la actualidad" en Laboratorio de Arte, núm.7 (1994), pp. 263-282.

- MAYNÉ, J., y R. SAGUÉS. [1983]“"Elementos de análisis del público para una mejora de la oferta museística" en III Jornadas de Difusión de Museos (1983), Bilbao, pp.36-38.

- MORALES MIRANDA, J. [1998] Guía práctica para la interpretación del patrimonio. El arte de acercar el legado natural y cultural al público visitante. Consejería de Cultura de la Junta de Andalucía, Sevilla, 1998.

- MORALES MIRANDA, Jorge.[1998] "La interpretación del patrimonio natural y cultural: todo un camino por recorrer" en Boletín del Instituto Andaluz del Patrimonio Histórico, 25 de diciembre 1998, pp.150-157.

- MORALES, Alfredo J. [1996] Patrimonio histórico-artístico. Conservación de bienes culturales. Ed. Historia 16, Información e Historia, S.L, Madrid, 1996.

- MORENO MARTÍNEZ, Jesús y DELGADO IGLESIAS, Francisco Javier.[1999] “Gestión económica y producción” en Los 
Conocimientos técnicos. Museos, Arquitectura. Arte (edición de Juan Carlos Rico), Ed. Silex, Madrid, 1999, pp.105-123.

- MOUREY, William. [1997] "La conservación preventiva para materiales artísticos y arqueológicos" en Actas del Coloquio Internacional La Conservación preventiva de los bienes culturales. ICOM, Comité Español, Vigo 1996 (edc. 1997), pp. 119-141.

- MUNARI, B. [1985] Diseño y comunicación visual. Contribución a una metodología didáctica. Ed. Gustavo Gili, Barcelona, 1985.

- Museos abiertos a todos los sentidos. Acoger mejor a las personas minusválidas. [1994] Ministerio de Cultura y O.N.C.E, Salamanca, 1994.

- NIETO GALLO, Gratiniano [1973] Panorama de los museos españoles y cuestiones museológicas, Edita: Asociación Española de Archiveros, Bibliotecarios, Museólogos y Documentalistas (ANABAD), Madrid, 1973.

- Normativa sobre el patrimonio histórico cultural, Ministerio de Cultura, Madrid, 1996.

- OLMOS ROMERO, Ricardo. [1988]"La investigación (de la cultura material) en los museos" en Boletín de ANABAD, XXXVIII, núm. 3, 1988, pp. 91-106.

- PÉREZ SÁNCHEZ. A.E. [1988] "Función del museo en la sociedad actual" en Archivos, bibliotecas y museos. X Congreso de Estudios Vascos, San Sebastián, 1988, pp. 129-136.

- $\quad$ PETIT, GONZAGUE. [1999]. "Marketing de museos: algunos puntos de vista" en Los Conocimientos técnicos. Museos, Arquitectura. Arte (edición de Juan Carlos Rico), Ed. Silex, Madrid, 1999; pp.19-74.

- PLENDERLEITH, H.J [1967] La conservación de antigüedades y obras de arte, Madrid, 1967.

- PORTA, E, MONTSERRAT, R.M y MORRAL, E.[1982] Sistema de documentación para Museos. Departamento de Cultura de la Generalidad de Cataluña e ICOM, Barcelona, 1982.

- PREVOT, Régis.[1993] “L’utilisation des rayonnages móviles pour le stockage des collections ethnographiques" en ConservationRestauration des Biens Culturels, núm.5, 1993, pp.16-19 
- RAMIREZ NEILA, José. [1999] "Climatización" en Los Conocimientos técnicos. Museos, Arquitectura. Arte (edición de Juan Carlos Rico), Ed. Silex, Madrid, 1999, pp.205-264.

- RAVÉ PRIETO, Juan Luis. [1996]"Difusión del patrimonio histórico en Andalucía" en Difusión del Patrimonio Histórico, Cuadernos de Instituto Andaluz del Patrimonio Histórico. Consejería de Cultura, Junta de Andalucía, Sevilla 1996, pp. 96-117.

- RICO, Juan Carlos. [1996] Montaje de exposiciones: museos, arquitectura, arte. Sílex Ediciones, Madrid, 1996.

- RICO, Juan Carlos. [1995] Los espacios expositivos. Museo, arquitectura, arte. Sílex Ediciones, Madrid, 1995.

- RIEGL, A. [1987] El culto moderno a los monumentos. Caracteres y origen, Madrid, 1987.

- RIVIÉRE, George Henry. [1993] La museología. Curso de Museología. Textos y testimonios. Ed. Akal, Madrid, 1993.

- RODA, C. de.[1983] "Repercusión del montaje didáctico o no didáctico del museo en la labor de los Departamentos de Educación" en Boletín del Museo de Zaragoza, núm.2, 1983, pp.21-23.

- RODRÍGUEZ LORITE, Miguel Ángel. [1994] "La luz en el Museo" en Miscelanea Museológica. Servicio Editorial Universidad del País Vasco, 1994, pp. 229-242.

- RODRÍGUEZ LORITE, Miguel Ángel. [1999] "Notas acerca de la iluminación de un retablo" en Pátina, época II, núm. 9, 1999, pp.94100 .

- ROMAN, Juan José.[1999] "Seguridad" en Museos, Arquitectura, Arte. Los conocimientos técnicos, en Los Conocimientos técnicos. Museos, Arquitectura. Arte (edición de Juan Carlos Rico), Ed. Silex, Madrid, 1999, pp. 321-377.

- ROMERO MORAGAS, Carlos.[1994] "Patrimonio, turismo y ciudad" en Boletín del Instituto Andaluz del Patrimonio Histórico, núm. 9 1994, pp.16-21.

- ROY, P. [1994] "La señalización en la práctica" en Museum, núm. 172, 1994, pp. 191-193. 
- RUIZ DE LA CANAL RUIZ MATEOS, M.D. [1994] "El conservador de museo y su problemática" en Boletín Instituto Andaluz del Patrimonio Histórico, núm.9, 1994, pp.44-51.

- Real Decreto 111/1986, de 10 de enero, por el que se desarrolla parcialmente la Ley 16/1985, de 25 de junio, del Patrimonio Histórico Español (B.O.E., núm.24, de 28 de enero).

- Real Decreto 1942/1993, de 5 de noviembre. Reglamento de instalaciones de protección contra incendios. Ministerio Industria y Energía, publicado en BOE 14-12-1993, núm.298, pp. 35159.

- SÁENZ ALiAGA, A.M. [1991] "La educación en el museo" en Boletín de Arte, núm. 12, 1991, pp.79-100.

- SAGUÉS I BAIXERAS, R. [1988] "Los Departamentos de Difusión cultural de los Museos", IV Jornadas DEAC Museos (1985), Madrid, 1988, pp.3-10.

- SAN MARTÍN MONTILLA, Concepción, RUIZ BANDERAS, Julián, HOLGADO CUESTA, María Luz y FERNÁNDEZ ROLDÁN, María Angeles. [1992] Aprender con...el Museo. Consejería de Educación y Ciencia, Junta de Andalucía, Sevilla, 1992.

- SANZ MARQUINA, T. [1985] "Situación de los departamentos educativos de los museos españoles" en Análisis e Investigaciones culturales, Madrid, núm.22, 1985, pp.81-91.

- SCHOUTEN, F. [1987] "La función educativa del museo: un desafío permanente" en Museum, núm. 156, 1987, pp.240-243.

- TAPOL, Benoit. [1997]"Conservación preventiva: el giro de los 90" en Actas del Coloquio Internacional La Conservación preventiva de los bienes culturales. ICOM, Comité Español, Vigo 1996 (edc. 1997), pp. $105-117$.

- THOMSON, Gary. [1998] El Museo y su entorno. Ediciones Akal, S.A, Madrid, 1998.

- $\quad$ TILlOTSON, Robert G. [1977] La Seguridad en los Museos. Consejo Internacional de Museos (ICOM), Paris 1977. Ministerio de Cultura, Madrid, 1980.

- Una experiencia pedagógica. Exposición "El niño y el museo" [1980], Dirección General de Bellas Artes, Archivos y Bibliotecas. Patronato Nacional de Museos, Ministerio de Cultura, Madrid, 1980. 
- VELA, Concha. "Patronatos de museos en España. Reflexión sobre la situación actual" en Investigación y Experiencias, pp.16-22.

- VERNER JONSON, E. y HORGAN, Joanne C. "La Mise en Rérseve des Collections de Musée" Aic, pp.103-129.

- VILLEGAS SÁNCHEZ, Rosario; GONZÁlEZ LÓPEZ, M ${ }^{\mathrm{a}}$ José; TORREJÓN DÍAZ, Antonio; FERNÁNDEZ RIZ, Eugenio; POZO GUTIÉRREZ, José $\mathrm{M}^{\mathrm{a}}$ del y ROSAL CARRANZA, Antonio. "El Centro de Intervención en el Patrimonio Histórico. Método, Objetivo y Servicios" en Boletín del Instituto Andaluz del Patrimonio Histórico, núm.14, Sevilla, pp.47-56.

- VLADÉS SAGÜES, María del Carmen.[1999] La difusión cultural en el museo: servicios destinados al gran público. Ed. Trea, Gijón, 1999.

- WRESSNIG, Felicitas.[1999] "El guía profesional: establecer puentes entre la conservación y el turismo" en Museum, núm. 201, 1999, pp. 40-43.

- ZUNZUNEGUI DÍAZ, Santos. [1990] Metamorfosis de la mirada. El Museo como espacio del sentido, Ed. Alfar, Sevilla, 1990.

- ZUNZUNEGUI DÍAZ, Santos. [1991] "Arquitecturas de la mirada" en Revista de Occidente, núm.117, febrero 1991, pp.31-46.

- ZUNZUNEGUI DÍAZ, Santos. [2000] Teoría y fundamentos de la comunicación y la semiología. Clase impartida en el Master de Museología, Universidad de Granada, 12 de mayo de 2000.Inédita. 